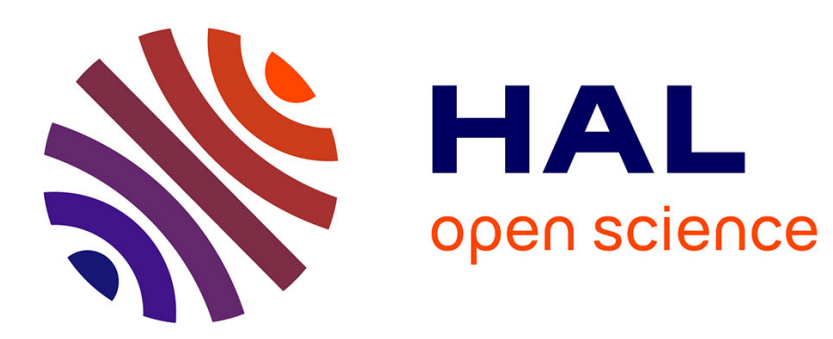

\title{
Early Silurian chitinozoans from the Qusaiba type area, North Central Saudi Arabia
}

\author{
Florentin Paris, Merrell A. Miller, Sa'Id Al-Hajri, Jan Zalasiewicz
}

\section{To cite this version:}

Florentin Paris, Merrell A. Miller, Sa'Id Al-Hajri, Jan Zalasiewicz. Early Silurian chitinozoans from the Qusaiba type area, North Central Saudi Arabia. Review of Palaeobotany and Palynology, 2015, 212, pp.127-186. 10.1016/j.revpalbo.2014.08.010 . insu-01094288

\section{HAL Id: insu-01094288 \\ https://hal-insu.archives-ouvertes.fr/insu-01094288}

Submitted on 12 Dec 2014

HAL is a multi-disciplinary open access archive for the deposit and dissemination of scientific research documents, whether they are published or not. The documents may come from teaching and research institutions in France or abroad, or from public or private research centers.
L'archive ouverte pluridisciplinaire HAL, est destinée au dépôt et à la diffusion de documents scientifiques de niveau recherche, publiés ou non, émanant des établissements d'enseignement et de recherche français ou étrangers, des laboratoires publics ou privés. 


\section{Accepted Manuscript}

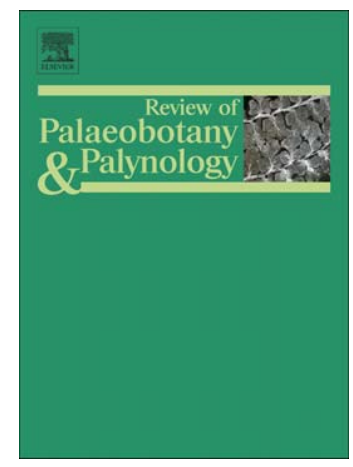

Early Silurian chitinozoans from the Qusaiba type area, North Central Saudi Arabia

Florentin Paris, Merrell A. Miller, Sa'id Al-Hajri, Jan Zalasiewicz

PII:

S0034-6667(14)00121-3

DOI:

doi: 10.1016/j.revpalbo.2014.08.010

Reference:

PALBO 3557

To appear in: $\quad$ Review of Palaeobotany and Palynology

Received date: $\quad 10$ April 2014

Accepted date: 21 August 2014

Please cite this article as: Paris, Florentin, Miller, Merrell A., Al-Hajri, Sa'id, Zalasiewicz, Jan, Early Silurian chitinozoans from the Qusaiba type area, North Central Saudi Arabia, Review of Palaeobotany and Palynology (2014), doi: 10.1016/j.revpalbo.2014.08.010

This is a PDF file of an unedited manuscript that has been accepted for publication. As a service to our customers we are providing this early version of the manuscript. The manuscript will undergo copyediting, typesetting, and review of the resulting proof before it is published in its final form. Please note that during the production process errors may be discovered which could affect the content, and all legal disclaimers that apply to the journal pertain. 


\title{
Early Silurian chitinozoans from the Qusaiba type area, North Central Saudi Arabia
}

Florentin Paris $^{\mathrm{a}, \mathrm{b}, *}$, Merrell A. Miller ${ }^{\mathrm{c}}$, Sa'id Al-Hajri $^{\mathrm{d}}$, Jan Zalasiewicz ${ }^{\mathrm{e}}$

${ }^{\mathrm{a}}$ Rue des Jonquilles, 35235 Thorigné-Fouillard, France

${ }^{\mathrm{b}}$ Géosciences-Rennes, CNRS UMR 6118, Université de Rennes 1, 35042 Rennes, France

${ }^{\mathrm{c}}$ IRF Group, Inc., 2357 East $23^{\text {rd }}$ street, Tulsa, OK 74114, USA

${ }^{d}$ Saudi Aramco, Exploration Technical Services Department, 31311 Dhahran, Saudi Arabia

${ }^{\mathrm{e}}$ Department of Geology, University of Leicester, University Road, Leicester LE1 7RH, UK

* Corresponding author. E-mail address: florentin.paris@orange.fr.

\begin{abstract}
Sixty one core samples from three shallow core holes (Qusaiba-1, Baq'a-3 and Baq'a-4) penetrating the Qalibah Formation (Qusaiba Member) in North Central Saudi Arabia were investigated. These core slabs corresponding to grey-greenish hemipelagic shale or silty-shale yield well-preserved and very abundant early Silurian chitinozoans. Most of the recorded chitinozoan assemblages are diverse and include several new species occurring with wellknown species. An informal early Rhuddanian chitinozoan assemblage dominated by Cyathochitina caputoi is documented in the lowermost part of the Qusaiba Member. The six chitinozoan biozones defined above this basal assemblage range from Aeronian to Telychian. They are considered of regional value for northern Gondwana. From the lowest to the highest they are the Angochitina qusaibaensis (pro parte), Conochitina alargada, Angochitina
\end{abstract}


hemeri, Angochitina macclurei, Tanuchitina obtusa and Euconochitina silurica biozones. The older regional biozones have been previously documented in Saudi Arabia whereas the two youngest ones, the eponymous index species of which were described from the subsurface of the Algerian Sahara, are documented for the first time in the Arabian Peninsula. Four subbiozones, of at least of regional application, are also defined in order to improve the precision of biostratigraphic correlation between Silurian lithostratigraphic units cropping out along the Arabian Shield and their counterparts in the subsurface of Central Saudi Arabia. Thanks to closely spaced and to regular sampling, the total range of several highly diagnostic forms as well as the interval of uncertainty between the successive chitinozoan biozones are better constrained. A hiatus with a duration of late Rhuddanian to early Aeronian separates the lowest informal chitinozoan assemblage from the qusaibaensis Biozone. A recent detailed study of the graptolites in the three cored holes provides independent chronostratigraphical control calibrating the previous chitinozoan-based age assignments. The qusaibaensis (pro parte), the alargada, and the hemeri chitinozoan biozones occur with the mid Aeronian convolutus graptolite Biozone whereas the macclurei chitinozoan Biozone extends through the early Telychian guerichi and turriculatus graptolite biozones. The obtusa and the silurica chitinozoan biozones occur in an interval devoid of usable graptolites. They are referred to the mid-late Telychian as they do not contain typical Sheinwoodian species.

Beside abundant chitinozoans and acritarchs, sporadic occurrences of scolecodonts and of eurypterid cuticle fragments are also noted in the organic residues. The presence of eurypterids reflects a shallowing trend in the sedimentary record, which is consistent with the distribution of the graptolites remains (siculae and/or rhabdosomes). Indeed, graptolites are common throughout the Qusaiba Member, except in the youngest processed samples presaging the shallower environments prevalent in the Sharawra Member. The taphonomy of 
the chitinozoans (isolated vesicles, chain-like structures, clusters, coprolites) and their environmental context are briefly discussed.

Fifteen new species are described and illustrated: Ancyrochitina alhajrii sp. nov., Ancyrochitina camilleae sp. nov., Armoricochitina crassicarinata sp. nov., Armoricochitina gengi sp. nov., Bursachitina baqaensis sp. nov., Conochitina viiuae sp. nov., Cutichitina minivelata sp. nov., Cyathochitina neolatipatagium sp. nov., Fungochitina merrelli sp. nov., Muscochitina olivieri sp. nov., Plectochitina alisawyiahensis sp. nov., Plectochitina alnaimi sp. nov., Plectochitina jaquelineae sp. nov., Plectochitina lucasi sp. nov., and Spinachitina geerti sp. nov.

Key words: Chitinozoans, Biostratigraphy, Systematics, Palaeoenvironments, early Silurian, Saudi Arabia, Northern Gondwana

\section{Introduction}

Under the auspices of the Commission Internationale pour l'étude de la Microflore du Paléozoïque (CIMP) a multi-disciplinary project with Saudi Aramco was initiated in the early 1990s for documenting organic-walled microfossils and biostratigraphy from the Ordovician and Silurian formations from Saudi Arabia. One of the goals was to develop a robust regional chitinozoan biozonation allowing correlation between the strata exposed along the margin of the Arabian Shield and the Early Palaeozoic units including source rocks and reservoirs buried beneath a Mesozoic and Cenozoic cover in central and southern Saudi Arabia (Fig. 1a). The first step is to establish and calibrate the chitinozoan biozones from the type areas of the 
Ordovician and Silurian formations and members exposed in the north-western part of Central Saudi Arabia. In Saudi Arabia, as in most of the tropical and sub-tropical desert regions, deep surficial weathering affects much of the exposed sedimentary rocks. This weathering proved to be responsible for the partial to total destruction of organic-walled microfossils and of the amorphous organic matter. In order to overcome this weathering phenomenon, shallow cores were drilled in the type area of the Qusaiba Member of the Qalibah Formation. They have been sampled and studied for the chitinozoans and other organic-walled microfossils (see this volume).

As far as chitinozoans are concerned, the Qalibah Formation is the most extensively investigated among the Saudi Arabian Early Palaeozoic lithostratigraphic units. The data are available in the following papers (McClure, 1988; Aoudeh and Al-Hajri, 1995; Paris et al., 1995; Paris and Al-Hajri, 1995; Al-Hajri and Paris, 1988; Paris et al., 2008) as well as an unpublished thesis (Al-Hajri, 1991) and numerous Saudi Aramco internal reports (more than 300 internal reports). The goal of the present study is to refine the northern Gondwana chitinozoan biozonation based on the Saudi Arabian collections with the introduction of new biozones and subbiozones applicable to the Arabian palaeoplate. Graptolites present in part of the section investigated (Zalasiewicz et al., 2007) give precise ties with the standard graptolite biozones) and consequently with the series and stages of the standard Silurian chronostratigraphy (Zalasiewicz et al., 2007, 2009. In addition, because the recorded material is abundant and very well-preserved, the present investigations provide helpful information about intraspecific morphologic variations of several critical species, especially for the index species of previously and newly identified biozones and subbiozones. The generally close sampling and the partial overlap of the three selected boreholes help refining of the ranges of the most significant index species. 
A more precise correlation with some incompletely understood chitinozoan assemblages is proposed (e.g. from the ISWH EW-9 well; see Paris, 1993) in terms of the early Silurian regional chitinozoan biostratigraphy of Saudi Arabia.

\section{Material and technical procedures}

\subsection{Samples}

Sixty one core samples were collected from the Qusaiba-1, Baq'a-3 and Baq'a-4 shallow core holes that penetrated the Qusaiba Member of the Qalibah Formation (Figs. 1a, 2). The Qusaiba-1 well was drilled in the Qusaiba type area, in north-western Central Saudi Arabia (Figs. 1a-b). The Baq'a-3 and Baq'a-4 shallow core holes are located to the north (Figs. 1a, c), in the type area of the latest Ordovician Baq'a Member of the Sarah Formation. In each borehole the sampling was regularly distributed and quite closely spaced in order to reduce the intervals of uncertainty between successive chitinozoan assemblages. The 28 samples from the Qusaiba- 1 core hole are distributed (mean interval of $5 \mathrm{ft}$, ca. $1.5 \mathrm{~m}$ ) through a $124.35 \mathrm{ft}$ thick sequence extending from $132.05 \mathrm{ft}$ to $256.40 \mathrm{ft}$ (Figs. 3, 9). The three oldest samples (core 27 at $256.4 \mathrm{ft}, 255.15 \mathrm{ft}$ and $254.8 \mathrm{ft}$ ) are documented and used for defining the Ordovician-Silurian boundary (see Paris et al. this volume). The 13 samples from the Baq'a-4 well (Figs. 4, 9) range through a $228.9 \mathrm{ft}$ thick sequence from core 7 (40.1 ft) to core 31 (269 ft). In the Baq'a-3 well (Figs. 5, 9) the 20 collected samples are less densely distributed (interval close to $20 \mathrm{ft}$, ca. $6 \mathrm{~m}$ ) along a $388.3 \mathrm{ft}$ thick sequence from core $14(130 \mathrm{ft})$ to core $56(518.3 \mathrm{ft})$. The lithology of the core slabs is rather homogenous, especially in the lower part of the three boreholes (Tables 
1-3). In general samples are grey to greenish or grey-greenish shale. Slight lithological variations are recognized for example in the lowermost part of the Qusaiba-1 (carbonaceous shale from $256.4 \mathrm{ft}$ to $254.8 \mathrm{ft}$ ) and silty shale intervals in the upper part of the Qusaiba-1 (136.5 ft to $132.05 \mathrm{ft}$ ) and in the Baq'a-3 core holes (cores 25 and 27). These lithological variations indicate shallowing of the palaeoenvironments. In the upper sample (core 14) from the Baq'a-3 well this shallowing trend is more conspicuous and announces the boundary between the Qusaiba and the Sharawra members. A significant increase of eurypterid cuticle fragments, and possibly of plant remains, confirms this shallowing trend in the upper part of the Baq'a-3 core hole (cores 14 to 21; Table 2). A concomitant disappearance of the graptolites is noted in these more shallow environmental settings (Tables 1 and 3). It is noteworthy that graptolites are not documented from the Sharawra Member (Al-Hajri and Paris, 1998, and unpublished data).

The absence of well-developed early Silurian black shale facies in the investigated cores is stressed. The only significant gamma ray peak is located at the carbonaceous shaly level at $254.8 \mathrm{ft}$ in the Qusaiba-1 core hole. This thin interval (possibly condensed) in the lowermost part of the Qusaiba Member (see Melvin, this volume) yields lowermost Rhuddanian chitinozoans in great abundance (Fig. 6; Table 19). This chitinozoan assemblage, discussed in detail in Paris et al. (this volume), occurs below a hiatus (gap) that separates these Rhuddanian deposits from the mid-Aeronian graptolitic shale.

\subsection{Technical procedure}

\subsubsection{Bedding plane observations}


All of the samples were examined using a binocular microscope at low to medium magnification $(16 \mathrm{x}$ or $40 \mathrm{x})$ prior to the crushing of the rock sample. The bedding plane surfaces of the core slab were wetted with alcohol in order to increase the contrast and to more easily recognize macrofossils and small organic remains. These observations revealed the occurrences of inarticulate brachiopods, ostracods and graptolites (siculae and rhabdosomes). Microfossils and larger organic-walled fossils, i.e. scolecodonts, plant, fragments, eurypterid cuticles and chitinozoans (as isolated vesicles, catenary structures, clusters and even coprolites comprised of crushed chitinozoans) were present with minerals (e.g., pyrite, heavy minerals, graphite) (Tables 1-3). The observation of the rock samples revealed that organic-walled microfossils are frequently concentrated on very thin darker bedding plane surfaces.

\subsubsection{Acid treatment and microfossil sorting}

The procedure described by Paris $(1981,2006)$ for the isolation and preparation of chitinozoans was used. The technique is based on handpicking of all, or more frequently of a measured percentage of the specimens present in the palynological residue. The picking under a stereoscopic binocular microscope is accomplished using a finely drawn glass micropipette. After sorting a quantified fraction (depending on the abundance of the recovered chitinozoans) or the entire chitinozoan population from the residue of a sample, the picked vesicles are mounted as permanent palynological slides in Canada balsam. The identification of the species and counting of the specimens is made using these slides, whereas the best-preserved or the most significant individuals are separately prepared for SEM examination. After SEM observations and photomicrography, these individuals are also mounted as permanent palynological slides in Canada balsam according the technique described in Paris (1978). This allows a secure preservation of the type material and 
illustrated individuals. Moreover it is possible to precisely relocate these specimens in the palynological slides with England Finder coordinates (see captions of Plates 1-18). In some cases (e.g., very abundant chitinozoans; new species) additional slides of selected specimens are prepared also.

\subsubsection{Specimen counting and repository}

Chitinozoans were too numerous in some samples for a complete inventory of all specimens (e.g. more than one thousand specimens per gram of rock in samples from 254.80 ft and 140.10 ft in Qusaiba-1, 289.1ft in Baq'a-3, and 261.2 ft in Baq'a-4). In such very rich residues, the picking and the counting were made from $20 \%, 10 \%$ or even $2 \%$ of the residue (Tables $1-3$ ). The chitinozoan abundance is expressed as number of specimens per gram of rock (Figs. 6-8). The relative frequency (as a percentage) was calculated for each identified chitinozoan taxon and for undetermined specimens. The relative abundances and the stratigraphic ranges for each species recorded for the three investigated wells are given on these range diagrams. All of the palynological preparations, including those with the illustrated material, are stored in the collections of Geosciences/OSUR (CNRS, Observatoire des Sciences de l'Univers de Rennes) at the University of Rennes (France) under the repository numbers IGR 72201 to 72300 for the Qusaiba-1 core hole, IGR 72301 to 72346 for the Baq'a-3 core hole and 72351 to 72376 for the Baq'a-4 core hole. These palynological slides and the corresponding SEM photos are registered in the "CHITINO_IGR" and in the "PHOTOCHITINO" databases of F. Paris.

\section{Chitinozoan biostratigraphy}


The proposed biozones and subbiozones are based on the First Appearance Datum (FAD) of selected index taxa or on the total range of the index species. This local biozonation is correlated with the regional Silurian chitinozoan zonation published by Paris et al. (1995) for Saudi Arabia. The chronostratigraphical age assignment is based on the graptolite zonation provided by the well-preserved, numerous, but often low diversity graptolite assemblages (Zalasiewicz et al., 2007) present with the chitinozoans in many samples from the Qusaiba-1, Baq'a-3 and Baq'a-4 cores. Calibration of the Saudi Arabian regional chitinozoan biozonation of Paris et al. (1995) and correlation with the global Silurian chitinozoan zonation of Verniers et al. (1995) are significantly improved in terms of standard graptolite zones. The precision of these graptolite/chitinozoan biozones ties is comparable to that published by Loydell et al. $(1998,2003,2010)$ for the Silurian of the Baltic area.

The average sampling interval is less than $6 \mathrm{ft}$ in the Qusaiba-1 well (Table 1; Fig. 3). In the two Baq'a core holes it is approximately 20 feet (Tables 2-3; Figs. 4-5) and is too large for an exact location of the FADs and LADs of the selected index species. This introduces intervals of uncertainty of a few meters thickness. Additional regional control on the respective range of the species is possible because the stratigraphic intervals investigated in the three shallow cores partly overlap those studied previously in the deep boreholes of Central Saudi Arabia e.g., UDYN-1, TINT-2, NYYM-2 (Paris, 1991, 1992; Paris et al., 1995) and ISWH EW-9 (Paris, 1993) (see Fig. 1a). Some of the taxa reported in open nomenclature or as nomina nuda in previous internal reports for Aramco (Paris, 1991, 1992, 1993, 2003, 2005) are formally described and biostratigraphically constrained here. McClure (1988) and Al Hajri (1991) have already illustrated several of these new species. The abundant populations recovered allowed a biometric evaluation of vesicle dimensions (Tables 4-18, 
Figs. 10-24).

The regional biozones and their subbiozones are defined and discussed in ascending stratigraphic order. Previously used chitinozoan biozone names are favoured. They are documented from diverse and abundant chitinozoan populations (usually more than 100 chitinozoans per gram of rock, and in a few cases more than 1000 individuals per gram of rock). The percentage of the indeterminate specimens is fairly low (usually less than $20 \%$ of the populations).

\section{1. "Assemblage 1"}

This chitinozoan assemblage is restricted to the lowermost part of the Qusaiba-1 core hole (core 27 at $256.4 \mathrm{ft}, 255.15 \mathrm{ft}$ and $254.8 \mathrm{ft}$; see Figs. 3 and 6) of the Qusaiba Member of the Qalibah Formation. It is only briefly mentioned here because it is defined elsewhere in this volume when documenting the boundary between the Sarah and the Qalibah formations in the Qusaiba-1 core hole (Paris et al., this volume). Cyathochitina caputoi (see Paris et al., this volume; pl. VI, figs. $1-3,5$ ) dominates this low diversity assemblage but with extremely high chitinozoan abundance in the dark carbonaceous shale at $254.8 \mathrm{ft}$ (more than 9000 chitinozoans per gram of rock). Belonechitina pseudarabiensis (see Paris et al. this volume; pl. VI, figs. 6, 9-10) is another important species of this "assemblage 1" (sensu Paris et al., this volume) as it occurs in the lower Rhuddanian of Jordan (Butcher, 2009), and is associated with very abundant Cyathochitina caputoi in the Nseirat section in Mauritania (Paris et al., 1998). In both localities it is associated with graptolites of the ascensus and/or acuminatus zones (see discussion in Paris et al., this volume). The $3.5 \mathrm{ft}$ thick highly bioturbated and condensed horizon yielding this assemblage is bracketed between the top of the Baq'a Sand 
Member of the Sarah Formation and a one foot thick bioturbated sandy bed at $253.5 \mathrm{ft}$ corresponding to the first Aeronian deposits (see discussion in Melvin, this volume). A hiatus is interpreted to be present within the lowermost part of the Qusaiba Member at ca. $253.5 \mathrm{ft}$.

\subsection{The Angochitina qusaibaensis interval-range Biozone}

Definition. The definition of the qusaibaensis Biozone is slightly emended here. Originally, as defined by Paris et al. (1995), it corresponded to the interval-range biozone between the last occurrence (LAD) of Lagenochitina nuayyimensis Paris and Al-Hajri, 1995 and the first appearance (FAD) of Conochitina alargada Cramer, 1967. Because of the spacing of the samples available in the type locality (well NYYM-2), an interval of uncertainty existed at the base and at the top of this qusaibaensis Biozone. Consequently, based on recent data, the qusaibaensis Biozone is redefined here as the interval-range biozone between the FAD of $A$. qusaibaensis and the FAD of C. alargada, which is the index species of the overlying biozone. In the Qusaiba-1 core hole much of the lower part of the qusaibaensis Biozone is missing (see above) and only its uppermost prt is represented from $251.10 \mathrm{ft}$ to $245.8 \mathrm{ft}$ (Figs. 6 and 9).

Main components. In the Qusaiba-1 well, the base of the Qusaiba Member is located in core 27 at $257.0 \mathrm{ft}$ (see discussion in Melvin, this volume). In the same core, at $256.4 \mathrm{ft}, 255.15 \mathrm{ft}$ and $254.8 \mathrm{ft}$, a distinctive chitinozoan assemblage from the basal beds of the Qusaiba Member dominated by C. caputoi is referred to the earliest Rhuddanian (see above, and Paris et al., this volume). Sedimentologic and ichnologic evidence indicates a hiatus at $254.5 \mathrm{ft}$ (Melvin, this volume). Immediately above this hiatus is a highly bioturbated sandy bed (ca. $1 \mathrm{ft}$ thick) directly overlain by typical Qusaiba shaly lithofacies (Fig. 3). The first sample available from 
these shales is $3.4 \mathrm{ft}$ above the hiatus and yields an abundant and diverse chitinozoan assemblage typical of the qusaibaensis Biozone (Fig. 6). Most of the specimens of $A$. qusaibaensis (25\% to 36\%) recorded in the lower part of the Qusaiba Member show a rather long neck (Plate I, 5; Plate II, 6-9) recalling those of A. hemeri. The chamber of $A$. qusaibaensis has no true spines but the distinction between the two species may be difficult when the ornamentation is partly eroded. A peculiar structure, never previously reported, is visible on many specimens of A. qusaibaensis from the lower samples in the Qusaiba-1 well. This unnamed structure consists of a very long membranous tubular sleeve (as long as the vesicle) extending from the prosome through the aperture (Plate II, 6a-b, 9). It is not known if this structure has a taxonomic significance (e.g., only present in a transitional form between $A$. qusaibaensis and A. hemeri) or if it is the result of excellent preservation related to very quiet depositional environments. Occurring with the dominant A. qusaibaensis, classical Aeronian components occur such as C. edjelensis (17\%; Plate I, 8), P. pseudoagglutinans (Plate I, 7), Belonechitina arabiensis (11\% at $248.3 \mathrm{ft})$ and C. caputoi Da Costa, 1971 (13\% at $245.8 \mathrm{ft}$; Plate II, 1-2). Among the subordinate species present are fairly rare but usually long ranging taxa occur (Fig. 6; Table 19), e.g. Pterochitina deichaii Taugourdeau, 1963 (Plate II, 3), Cutichitina minivelata sp. nov., Calpichitina sp. aff. C. densa (Eisenack, 1962), Conochitina vitrea Taugourdeau, 1962 and C. elongata (Plate I, 3-9). Stratigraphically of greater interest is Muscochitina olivieri sp. nov. (20\% at $251.1 \mathrm{ft}$; Plate I, 1, 4), as this new species seems restricted to the upper part of the qusaibaensis Biozone. It was recorded but not illustrated (“Sphaerochitina sp. 2" among the reported Sphaerochitina sp. indet., see synonymy list and discussion below in the Systematic section) in the subsurface of Central Saudi Arabia (UDYN-1, core 17 at 16.635.7 ft, and TINT-2, core 20, at $16.872 \mathrm{ft}$ ) (Paris, 1991, 1992). A last species is Conochitina viiuae sp. nov. a long slender species (Plate I, 2; Plate II, 4-5), abundant at $245.8 \mathrm{ft}$ (15\%; see Fig. 6). 
Range. In the Qusaiba-1 well, the qusaibaensis interval-biozone extends from $251.1 \mathrm{ft}$ to 238.2/6 ft where the lowest occurring C. alargada are recorded (Fig. 6; Table 19). The base of the biozone is poorly defined in the NYYM-2 well (Paris et al., 1995, p. 81). Recent investigations on the chitinozoans of the Murzuk Basin, SW Libya (Paris et al., 2012) have shown that A. qusaibaensis is not associated with L. nuayyimensis at least in the main range part of the latter species. This is consistent with the range of A. qusaibaensis in UDYN-1, where no specimens of L. nuayyimensis have been recorded (Paris et al., 1995). Because of the restricted range of M. olivieri sp. nov., identified as "Sphaerochitina sp. indet." in the upper investigated cores of wells TINT-2 (core 20, at $16.872 \mathrm{ft}$; Paris, 1992) and UDYM-1 (core 17 at $16.635 .7 \mathrm{ft}$; Paris, 1991), it is considered that only the upper part of the qusaibaensis Biozone is represented in the Qusaiba-1 core hole.

Age assignment. In a previous paper, the base of the qusaibaensis Biozone was referred to the upper Rhuddanian, based on the occurrence of graptolites of the cyphus Biozone in its lowermost part in the TAYMA-1 well (see Paris et al., 1995, p. 81). The age of the upper part of the qusaibaensis Biozone, however, was not firmly constrained due to a sample gap at its highest occurrence in the NYYM-2 well, and to the absence of direct ties with graptolites or other fossils of stratigraphic value. The whole biozone was therefore tentatively referred to the upper Rhuddanian-lower Aeronian (Paris et al., 1995, fig. 4). The present material provides a much more precise calibration of the upper part of the qusaibaensis Biozone based on the graptolites of the convolutus Biozone recorded by Zalasiewicz et al. (2007) in the Qusaiba-1 core hole (Fig. 9). The interval attributed to the upper part of the qusaibaensis intervalbiozone (251.10 ft to $254.6 \mathrm{ft}$ ) yields graptolites of the convolutus Biozone, hence we can conclude that the qusaibaensis interval-biozone ranges from the upper Rhuddanian (upper part 
of the cyphus Biozone) to the mid-Aeronian (lower part of the convolutus Biozone). $M$. olivieri sp. nov. with a range apparently restricted to the upper part of the qusaibaensis Biozone, could represent a key chitinozoan species to indicate the early mid-Aeronian (i.e., lower part of the convolutus Biozone). It allows for instance to assign an early mid-Aeronian age for core 17 from the UDYN-1 well, and also for core 20 from the TINT-2 well. Nevertheless, an olivieri subbiozone is not yet proposed as the FAD of M. olivieri sp. nov. is not completely documented (hiatus in the Qusaiba-1core hole; see above).

\subsection{The Conochitina alargada total-range Biozone}

Definition. This biozone is a close equivalent to the "Conochitina alargada - Plectochitina paraguayensis concurrent-range biozone" of Paris et al. (1995). The closely spaced samples and the good graptolite control available in the Qusaiba-1 core hole, lead to a minor emendation of the original definition. The alargada Biozone is defined here as the total-range biozone of C. alargada Cramer, 1967. In the Qusaiba-1 core hole, the base of this chitinozoan biozone is located $15.3 \mathrm{ft}$ (ca. $4.6 \mathrm{~m}$ ) above the base of the Qusaiba Member at 238.2/6 ft. The index species is moderately abundant in this sample (15\% of the assemblage) but dominates the chitinozoan assemblage recorded at $235.4 \mathrm{ft}(37 \%)$. C. alargada has its LAD at $210.9 \mathrm{ft}$ with moderate to low abundances (Fig. 6). The top of the biozone is fixed at $210.9 \mathrm{ft}$ in spite of the presence in this sample of very rare A. hemeri, the index species of the succeeding biozone (Figs. 6 and 9). The alargada Biozone as defined here corresponds to "Assemblage 2" (="alargada-paraguayensis interval-range biozone") of Paris (2003).

Main components. The chitinozoan assemblages recorded in the alargada Biozone are diverse with up to 12 species (Fig. 6; Table 19). Angochitina qusaibaensis is the dominant 
species as it is the case in the underlying biozone (50\% of the chitinozoans at $228.8 \mathrm{ft}$ and $44 \%$ at $225.5 \mathrm{ft}$ ) (Fig. 6). Conochitina alargada is moderately abundant (1\% to $15 \%$ ), except at $235.4 \mathrm{ft}(35 \%)$ and in the upper part of the biozone where C. alargada represents less than $5 \%$ of the recorded species. C. edjelensis (14\% at $231.4 \mathrm{ft})$, and Plectochitina pseudoagglutinans (Plate III, 7-8; 39\% at 238.2/6 ft and $38 \%$ at $217.2 \mathrm{ft}$ ) are the other most common components (Fig. 6; Table 19). Subordinate species are fairly rare (usually less than 3\%) and long ranging taxa (Fig. 6; Table 19), as e.g. B. arabiensis, P. deichaii (Plate III, 11), Cutichitina minivelata sp. nov., Belonechitina paravitrea Paris and Al-Hajri, 1995 (Plate III, 3) and C. sp. aff. C. densa (Plate III, 5). Another species, Cutichitina minivelata sp. nov. (Plate III, 9), shows a fluctuating abundance, ranging from none at $238.2 / 6 \mathrm{ft}$ to $12 \%$ at 225.5 ft. At the top of the biozone, at $210.9 \mathrm{ft}$, Plectochitina alnaimi sp. nov., a small form with birooted processes and blunt cones or granules on the chamber (Plate III, 6), is abundant (23\% at $210.9 \mathrm{ft}$ ) (Fig. 6; Table 19). This new species should be a useful guide for locating the top of the alargada Biozone.

Range. In the Qusaiba-1 core hole, the alargada interval-range biozone extends from 238.2/6 $\mathrm{ft}$ to $210.9 \mathrm{ft}$. The boundary with the overlying hemeri Biozone is not "sharp" as the first undisputable specimens of $A$. hemeri are observed at $210.9 \mathrm{ft}$, i.e. together with the last recorded C. alargada (Fig. 6; Table 19). In this sample A. hemeri is extremely rare (ca. $0.2 \%$ of the recorded chitinozoans) where A. qusaibaensis still represents $9 \%$ of all the chitinozoans recorded in this sample (see Fig. 6).

Age assignment. The graptolites of the convolutus Biozone identified by Zalasiewicz et al. (2007) in the Qusaiba-1 core hole provide a robust age control for the alargada Biozone as presently defined. The whole Qusaiba succession yielding chitinozoans of the alargada 
Biozone are unambiguously of mid-Aeronian age. This precise graptolite control also allows a mid Aeronian age to be assigned to some well-known, but previously poorly stratigraphically controlled species such as $C$. edjelensis, C. elongata, $C$. vitrea, $P$. deichaii and $P$. pseudoagglutinans described by Taugourdeau $(1962,1963)$ in south-eastern Algerian Sahara, Edjelé area, well Dl-101, samples at $2863 \mathrm{ft}(871 \mathrm{~m})$ and $2761 \mathrm{ft}(840 \mathrm{~m})$ depth. Similar assemblages occur also in Cyrenaica (eastern Libya) (Molyneux and Paris, 1985; Paris, 1988)

\subsection{The Angochitina hemeri Biozone}

Definition. This biozone is defined here as the interval-range biozone between the first significant (more than 3\%) occurrence of A. hemeri and the FAD of A. macclurei Paris and Al-Hajri, 1995. It corresponds to the two former regional biozones defined by Paris et al. (1995) and respectively labelled "concurrent range biozone of Sphaerochitina solitudina and Angochitina hemeri" and "interval zone of $A$ hemeri". These biostratigraphic subdivisions were defined from samples of cores 18 and 17 of the TINT-2 well, where an uncored interval of about $83 \mathrm{ft}(25 \mathrm{~m})$ separates the last occurrence of $A$. hemeri from the first occurrence of $A$. macclurei. The material recovered from the Qusaiba-1 and Baq'a-4 core holes provides the missing information about this critical sample gap in the TINT-2 well and permits a much more accurate control on the base and on the top of the hemeri Biozone.

Main components. In the Qusaiba-1 core hole, Angochitina species (Plate I, 5; Plate II, 6-8) with the general morphology of $A$. hemeri (i.e., ovoid chamber with a long and slender neck) but with blunt spines or tubercles recalling the ornamentation of A. qusaibaensis are already present in the lowermost part of the Qusaiba Member. These puzzling specimens make it difficult to locate precisely the FAD of A. hemeri in the Qusaiba-1 core hole, where very rare 
(0.2\%) specimens are recorded at $210.9 \mathrm{ft}$. Typical specimens of the index species from the sample at $176.05 \mathrm{ft}$ are illustrated (Plate IV, 5-6; Plate V, 1). In the Baq'a-4 core hole $A$. hemeri may be abundant (39 \% of the identified individuals at $140.6 \mathrm{ft}$; Fig. 7; Table 20) where it coexists with very rare C. alargada (Plate VIII, 4), B. paravitrea (Plate VIII, 5, 8), and B. arabiensis (1\% of the recorded species). Plectochitina alnaimi sp. nov. (Plate IV, 9; Plate V, 2, 10), already present in the underlying biozone, is the most abundant species (from $17 \%$ at $167.7 \mathrm{ft}$ to $70 \%$ at $140.1 \mathrm{ft}$ ) from the lower part of the hemeri Biozone in the Qusaiba1 core hole (Fig. 6). It can be considered as an auxiliary species for identifying the lower part of the hemeri Biozone.

Other species are restricted to a single sample, where they can be abundant. Linochitina? sp. (Plate VI, 1-2) is reported only in core 14 at $132.05 \mathrm{ft}$ (29\% of the recorded chitinozoans; Fig. 6). This form is kept in open nomenclature because the copula normally present in Linochitina species has not been observed (it might alternatively be referred to as an Euconochitina). Anthochitina primula Nestor, 1994 is exclusively recorded at $145.9 \mathrm{ft}$ in the Qusaiba core hole. This species with a distinctive serrate or denticulate carina (Plate V, 3, 1112) represents $13 \%$ of the chitinozoans from this sample (Fig. 6). In the Baq'a-4 well, the most dominant species is Ancyrochitina gr. aculeata (up to $68 \%$ of the identified specimens). Other species may be sporadically abundant in this well, such as C. caputoi (48\% at $269.0 \mathrm{ft}$ in the deepest investigated sample), or P. deichaii (13\% at $269.0 \mathrm{ft}$ ) but discontinuously represented stratigraphically higher (Fig. 7; Table 20). Spinachitina geerti sp. nov. (Plate VII, $1,4-5,7-8)$ is an interesting and fairly short ranging species, recorded only at $240.7 \mathrm{ft}$ and 163.0 ft in Baq'a-4 (Fig. 7). Plectochitina paraguayensis Wood and Miller, 1991 (Plate IV, 7-8; Plate V, 5, 9) has its FAD at $240.35 \mathrm{ft}(10 \%)$ in the Qusaiba-1 well and is moderately abundant (4 \% to $18 \%$ ) up to $145.9 \mathrm{ft}$. Plectochitina cf. clathrospinosa (Plate V, 6) has very rare (less the 1\%) and sporadic occurrences in the youngest samples of this Qusaiba-1 well 
(Fig. 6; Table 19). The isolated occurrence of very abundant Cyathochitina cf. caputoi (Plate IV , 1) at $167.7 \mathrm{ft}$ is striking. This increase in abundance may be related to environmental changes more favourable for Cyathochitina species as e.g. Cyathochitina neolatipatagium sp. nov. (Plate VI, 7-8, 11) is also the dominant chitinozoan species $(71 \%$ at $134.2 \mathrm{ft}$ and $59 \%$ at $133.45 \mathrm{ft}$ ) in the upper part the Qusaiba-1 core hole (Fig. 6). Männil (1971) had already pointed out such abundant but sporadic occurrences of Cyathochitina species in Baltoscandia.

Range. The first undisputable $A$. hemeri specimens are identified at $210.9 \mathrm{ft}$. Because the index species is too rare in this sample ( $0.2 \%$ of the recorded chitinozoans), and for practical reasons of identification, the base of the biozone is fixed at $204.35 \mathrm{ft}$. The species is wellrepresented from $176.05 \mathrm{ft}$ to $132.05 \mathrm{ft}$ (highest processed sample) in the Qusaiba-1 core hole and is abundant from $269.0 \mathrm{ft}$ to $140.6 \mathrm{ft}$ in the Baq'a-4 well (Fig. 7; Table 20). It must be stressed that a few A. macclurei precursors (Plate VII, 3) occur in the upper part of the hemeri Biozone in Baq'a-4 (Fig. 7), whereas the base of the succeeding macclurei Biozone is located at $140.6 \mathrm{ft}$ in the Baq'a-4 core hole. In this well, indisputable A. macclurei specimens are associated with abundant representatives of A. hemeri at $140.6 \mathrm{ft}$. Consequently, the totalrange of these two biozonal index species overlaps slightly. In the Baq'a-4 well the hemeri Biozone extends in the Qusaiba Member, at least along a $106 \mathrm{ft}$ (ca. $32 \mathrm{~m}$ ) thick sequence from $269.0 \mathrm{ft}$ to $163.0 \mathrm{ft}$, and possibly more, as there is an interval of $22.4 \mathrm{ft}$ without available samples. The strata corresponding to the FAD of the index species were not penetrated in this well. In the TINT-2 well the biozone was documented in a $83 \mathrm{ft}(25 \mathrm{~m})$ thick interval. $A$. hemeri (see synonymy in Paris and Al-Hajri, 1995) was originally called "Sphaerochitina longicollis form B" in Paris (1992).

Age assignment. The hemeri Biozone was tentatively referred to the early Telychian by Paris 
et al. (1995) based on the known range of accompanying chitinozoan species in Baltoscandia (Nestor, 1982, 1990, 1994), and recently calibrated by means of graptolites zones (Loydell et al., 1998, 2003, 2010). In the present study numerous graptolites of the convolutus Biozone identified by Zalasiewicz et al. (2007) in the Qusaiba-1 well, in core samples yielding chitinozoans of the hemeri Biozone, provide robust independent age control. Based on these graptolite data, the hemeri Biozone is at least partly of Aeronian age. The upper part of the hemeri Biozone is present in the Baq'a-4 core hole, but only the oldest investigated sample at $269.0 \mathrm{ft}$ yields graptolites firmly assigned to the convolutus Biozone (Zalasiewicz et al., 2007, fig. 6). In this latter well, the graptolites accompanying the chitinozoans corresponding to the remaining upper part of the hemeri Biozone (up to $163.0 \mathrm{ft}$ ) are only tentatively referred to the convolutus Biozone. Therefore, it is not excluded that the hemeri Biozone may extend into the lower Telychian. The occurrence of Spinachitina geerti sp. nov. at $240.7 \mathrm{ft}$ and $163.0 \mathrm{ft}$ in the Baq'a-4 core hole is of interest as in Belgium, this new species originally identified as $S$. spinosa nomen nudum in Van Grootel (1990), extends into the sedgwickii graptolite Biozone and in part of the crispus graptolite Biozone. It is worth noting that Anthochitina primula (restricted occurrence at $145.9 \mathrm{ft}$ in the Qusaiba-1 core hole) was described by Nestor (1994, pl. VIII, figs. 1-6) from the uppermost part of the Velise Formation (sample at $140.1 \mathrm{~m}$ ) in the Viki core hole, in Estonia. This sample was assigned to the lower part of the Adavere Baltic stage correlated with the turriculatus graptolite Biozone (see Nestor, 1994, fig. 28). A. primula is likely present in Québec, in the Jupiter Formation of similar age (Achab, 1981).

3.5. The Ancyrochitina camilleae subbiozone

Definition. This local subbiozone corresponds to the total-range of Ancyrochitina camilleae sp. nov. (Plate VIII, 1, 6) documented in the Baq'a-4 core hole (Fig. 7; Table 20). It 
characterizes the uppermost part of the hemeri Biozone and does not extend into the macclurei Biozone.

Main components. Most of the species recorded in the lower part of the hemeri Biozone, e.g. A. hemeri, B. paravitrea, B. arabiensis, A. gr. aculeata, extend into this subbiozone. In addition to A. camilleae sp. nov., another short ranging species, Bursachitina baqaensis sp. nov. (Plate VIII, 3) and an atypical specimen of $S$. cf. geerti sp. nov. (eroded spines?; Plate VIII, 2) are restricted to the subbiozone and therefore are representative of the uppermost part of the hemeri Biozone.

Range. The camilleae subbiozone ranges at least on $38.2 \mathrm{ft}$ (i.e. $11.6 \mathrm{~m}$ ) in the Baq'a-4 shallow core (from $201.2 \mathrm{ft}$ to $163.0 \mathrm{ft}$; Fig. 7; Table 20). An interval of uncertainty (no samples available; see Table 2) of about $20 \mathrm{ft}$ (ca. $6 \mathrm{~m}$ ) exists below and above the documented range of this new species, which could therefore occur over a maximum thickness of $80.6 \mathrm{ft}$ (ca. $24.5 \mathrm{~m})$.

Age assignment. The camilleae subbiozone is tentatively attributed to the upper Aeronianlowermost Telychian? because in the Baq'a-4 core hole the index species ranges in an interval situated between strata yielding graptolites firmly attributed to the convolutus Biozone (269.4 $\mathrm{ft})$ below and to the guerichi Biozone (135.55 ft) above the top. Less conclusive graptolites occurring at $218.55 \mathrm{ft}$ to $268.90 \mathrm{ft}$ are questionably referred to the convolutus Biozone (Zalasiewicz et al., 2007, fig. 6). The LAD of A. camilleae sp. nov. is located close to but below the FAD of Calpichitina densa regarded as a Telychian species in Baltoscandia (see discussion below for the macclurei Biozone). 


\subsection{The Angochitina macclurei Biozone}

Definition. This biozone as originally defined by Paris et al. (1995) corresponded to the acme-range biozone of Angochitina macclurei Paris and Al-Hajri, 1995. In its present usage, the macclurei Biozone corresponds to the interval-range biozone between the FAD of the index species and the LAD of Armoricochitina crassicarinata sp. nov. (Fig. 8; Table 21). This fits quite well with the total-range of $A$. macclurei. Two morphotypes are recorded in the samples from the Baq'a-3 and Baq'a-4 core holes. They are regarded as remaining within the intraspecific variations of the index species. The first morphotype is rather short (total length ranging approximately from $220 \mu \mathrm{m}$ to $280 \mu \mathrm{m}$, and the ratio of the length of the neck to the chamber length is less than three) (e.g., Plate VII, 2-3; Plate IX, 2; Plate XI, 1; Plate XIV, 1, 5). The second morphotype, which corresponds exactly to the type material of the species, is much more slender and longer (up to $400 \mu \mathrm{m}$ ). It has a more spherical chamber and a long and narrow neck (about three times the chamber length) (e.g., Plate XII, 4-5). This morphotype is common in the Baq'a-3 well. The specimens with very rare spines on the neck are regarded as gradational between $A$. hemeri and A. macclurei. A biometric study would possibly reveal an evolutionary lineage within A. macclurei but the present samples are not suitable for such study.

Main components. A few species, e.g. C. caputoi (3\% or less; Plate XIV, 3) and Calpichitina sp., already recorded in the hemeri Biozone are still sporadically recorded in the macclurei Biozone in the Baq'a-4 and Baq'a-3 core holes (Figs. 7-8). Other taxa, e.g. Conochitina cf. edjelensis (6\% or less), P. pseudoagglutinans (Plate VII, 6), and P. deichaii (Plate XVI, 8), extend beyond the upper limit of the biozone as documented in the Baq'a-3 core hole (Fig. 8; Table 21). Some new species are restricted to the lower part, e.g. Fungochitina merrelli sp. 
nov. (Plate IX, 1, 3; Plate X, 5) and Ancyrochitina alhajrii sp. nov. (Plate X, 2, 4), when others are restricted to the upper part of the macclurei Biozone (Fig. 8), e.g. Armoricochitina crassicarinata sp. nov. (Plate XI, 2; Plate XII, 2, 6; Plate XIV, 7) and Armoricochitina? sp. (Plate XIII, 2). Except for A. alhajrii sp. nov. and A. crassicarinata sp. nov., which represent respectively $27 \%$ to $42 \%$, and $1 \%$ to $24 \%$ of the identified taxa in the corresponding samples, the relative abundance of the other new species is less than $10 \%$. Calpichitina densa (Plate VIII, 7; Plate XII, 8; Plate XIII, 3) ranges virtually through the entire macclurei Biozone and can be used as an alternative species for identifying this biozone. C. densa, however, has a very low relative abundance ranging from $1 \%$ to $4 \%$ (Figs. 7-8). In the Baq'a-4 core hole, Plectochitina alisawyiahensis sp. nov. has its FAD at $140.6 \mathrm{ft}$, exactly in the same sample as A. macclurei. The relative frequencies of this polymorphic species fluctuate greatly. The species is separated here from other very similar but ill-defined Plectochitina species, e.g., $P$. saharica (Taugourdeau, 1962) and P. combazii Cramer, 1967 because P. alisawyiahensis sp. nov. has wider processes (see discussion below, in the Systematic section). The latter includes individuals with two (e.g., Plate IX, 4, 6; Plate XII, 7) or several sets of simple /or branched processes anastomosed at their distal extremity (e.g., Plate XV, 4-5, 8). P. alisawyiahensis is missing in some samples (e.g., in the lower part of the Baq'a-3 core hole) but dominates the neighbouring chitinozoan assemblage (55\% of the taxa recorded at $450.1 \mathrm{ft}$ ) (Fig. 8; Table 21). The species extends above the FAD of A. macclurei and occurs sporadically up to 150.4 $\mathrm{ft}$ depth in the Baq'a-3 core hole.

Range. In Baq'a-4, the macclurei Biozone occurs from $140.6 \mathrm{ft}$ to the highest investigated sample at $40.1 \mathrm{ft}$. Due to the sampling intervals, there is an uncertainty interval of less than $22.4 \mathrm{ft}(6.8 \mathrm{~m})$ on the FAD of the index species. In the Baq'a-3 core hole, A. macclurei occurs from the deepest processed sample at $518.3 \mathrm{ft}$ up to $330.4 \mathrm{ft}$, i.e. in an interval of at least 
$187.9 \mathrm{ft}$ thick (ca. $57 \mathrm{~m}$ ) (Figs. 8 and 9). The last well-represented A. macclurei specimens are observed at $306.0 \mathrm{ft}$ (Fig. 8; the specimen recorded at $250.5 \mathrm{ft}$ is regarded as questionable). Consequently, according to the definition adopted here the macclurei Biozone is very close to the total-range of the eponymous species. Moreover, A. macclurei is usually dominant in this biozone (relative abundances close to $50 \%$ or even exceeding $50 \%$ in the upper part of the biozone; see Fig. 8). This acme-interval was also documented in the TINT-2 well (Paris et al., 1995), where the species was originally recorded under the provisional name "Sphaerochitina longicollis form A" by Paris (1992) (see synonymy in Paris and Al-Hajri, 1995).

Age assignment. The recent investigations on the graptolites from the Baq'a-3 and Baq'a-4 core holes (Zalasiewicz et al., 2007) provide direct ties with the early Telychian guerichi and possibly turriculatus graptolite biozones (Fig. 9). The guerichi Biozone is documented in the Baq'a-4 well from $135.55 \mathrm{ft}$ to $37.1 \mathrm{ft}$, and from $500.50 \mathrm{ft}$ to $454.40 \mathrm{ft}$ in the Baq'a-3 well, where the turriculatus Biozone sensu lato is identified at $367 \mathrm{ft}$ and from $303 \mathrm{ft}$ to $336 \mathrm{ft}$ (Zalasiewicz et al., 2007, fig. 6). This means that the entire macclurei Biozone occurs within the lower Telychian. Until the recent investigations on the graptolites from the Qusaiba type area in northern Central Saudi Arabia, the macclurei Biozone was tentatively referred to the middle part of the Telychian (Paris et al., 1995, fig. 4). A. macclurei was restricted to the northern Gondwana regions and the previous correlation was therefore based on the range of accompanying species such as Calpichitina densa whose age assignment is better constrained in Baltoscandia (Laufeld, 1974; Nestor, 1994). In spite of the compression that greatly modifies the silhouette of all the individuals available in the three studied core holes, the very distinctive chain-forming Desmochitininae from the Baq'a-4 (120.1 to $40.1 \mathrm{ft}$; see Fig. 7; Table 20) and from the Baq'a-3 core holes (518.3 ft to $306.0 \mathrm{ft}$; Fig. 8; Table 21) are here assigned to Calpichitina densa (Plate VIII, 7; Plate XII, 8; Plate XIII, 3). Among the closest 
related species is Margachitina banwyensis Mullins, 2000. The northern Gondwana specimens have no evidence of a peduncle (see Plate XII, 8b) as one would expect in the lineage of the earliest Margachitina. The present form has been provisionally identified in Libya as ?Margachitina leonensis (Hill et al., 1985, pl. 13, figs. 9a-b) or as M. margaritana (Paris, 1988a). C. densa, whose total range is virtually identical to that of A. macclurei in the Baq'a-4 and Baq'a-3 core holes, is a well-known species in the Telychian of Baltoscandia (see references in Nestor, 1994; Verniers et al., 1995; Loydell et al., 2003, 2010) and in the U.K. (see references in Mullins and Loydell, 2001).

\subsection{The Fungochitina merrelli subbiozone}

Definition. This local subbiozone corresponds to the interval-range of Fungochitina merrelli sp. nov. between its FAD and the FAD of $A$. crassicarinata sp. nov., as documented in the Baq'a-3 and Baq'a-4 wells (Figs. 7-8). Fungochitina merrelli sp. nov. is a small chitinozoan (total vesicle length ranging approximately from 100 to 120 micrometers) with a conical chamber terminated by a short neck (chamber and neck lengths are nearly equal) (Plate IX, 1 , 3; Plate X, 5). Densely distributed slender spines occasionally with lambda-shaped proximal ends (Plate X, 5b) cover the chamber. The very low frequency of $F$. merrelli sp. nov. in the Baq'a 3 core hole $(<1 \%)$ at $408.7 \mathrm{ft}$, i.e. at the base of the succeeding crassicarinata subbiozone) suggests that the merrelli interval-range subbiozone, as defined here, corresponds very closely to the total range of the index species.

Main components. Several species among the taxa recorded in the macclurei Biozone are also represented in this subbiozone (see Figs. 7-8 for their respective relative frequencies). A few taxa are long ranging species with moderate to low relative frequencies, e.g. P. deichaii 
and C. caputoi (Fig. 8; Table 21). Some other species, such as $P$. alisawyiahensis sp. nov. (dominant species with a relative frequency of $55 \%$ at the base of the subbiozone), A. alhajrii sp. nov. (also well-represented in the biozone; Fig. 8) and C. densa, have their FAD close to, or at the base of the merrelli local subbiozone and extend above its upper limit. When compared to the abundance of $A$. alhajrii sp. nov. in the merrelli local subbiozone in the Baq'a-3 core hole (relative frequencies ranging from $42 \%$ in the uppermost merrelli subbiozone to $27 \%$ just above, at $388 \mathrm{ft}$ ), its absence in the Baq'a- 4 well is puzzling. This absence of record may be due to the fact that only the lower part of the merrelli local subbiozone is documented in Baq'a-4. In that case the range of F. merrelli is much shorter in Baq'a-3 if one excludes the questionable individuals recorded at $518.3 \mathrm{ft}$ in Baq'a-3.

Range. In Baq'a-4, F. merrelli sp. nov. is recorded at $120.1 \mathrm{ft}$ and at $40.1 \mathrm{ft}$ (highest processed sample in this shallow core). Its total range is therefore present in at least of $80 \mathrm{ft}$ (24.3 m) with an uncertainty of about $20.5 \mathrm{ft}(6.2 \mathrm{~m})$ concerning the FAD of the index species, due to the sample spacing (Fig. 7; Table 20). The absence of A. alhajrii sp. nov. and of $A$. crassicarinata sp. nov. in the highest investigated sample in the Baq'a-4 core hole, suggests that the top of the merrelli subbiozone is not reached at $40.1 \mathrm{ft}$ in this shallow well (see discussion above).

In Baq'a-3, F. merrelli is recorded from $450.1 \mathrm{ft}$ to $408.7 \mathrm{ft}$ (in this last occurrence, however, its relative abundance is less than 1\%). Thus, its total range is at least of $41.4 \mathrm{ft}(12.6 \mathrm{~m})$, with an uncertainty close to $20 \mathrm{ft}$, concerning respectively its FAD and its $\mathrm{LAD}$, due to the sample spacing (Fig. 8; Table 21).

Age assignment. F. merrelli sp. nov. does not provide independent age control. Based on the 
associated graptolites of the guerichi Biozone recorded in wells Baq'a-4 (135.55 ft to $37.1 \mathrm{ft}$ ) and Baq'a-3 (500.5 ft to $454 \mathrm{ft}$ ) (Zalasiewicz et al., 2007, figs. 6 and 5 respectively) the merrelli subbiozone fits almost perfectly within this lowermost Telychian graptolite biozone (Fig. 9).

3.8. The Armoricochitina crassicarinata subbiozone

Definition. This local subbiozone corresponds to the total range of Armoricochitina crassicarinata sp. nov., as documented in the Baq'a-3 core hole (Fig. 8; Table 21). A. crassicarinata sp. nov. is a rather small chitinozoan (the vesicle length ranges around 120 $\mu \mathrm{m})$. A. crassicarinata sp. nov. was reported in core 1 from well ISWH EW-9 with a provisional name Armoricochitina? sp. nov. A (see Paris, 1993, pl. 2: figs. 4-5).

\section{Main components}

Most of the species recorded in the macclurei Biozone, e.g. P. deichaii, C. densa, $P$. alisawyiahensis sp. nov. with the exception of $F$. merrelli sp. nov. are represented in this subbiozone. Other taxa have their FAD within the crassicarinata subbiozone, e.g. Tanuchitina obtusa (Plate XIII, 4-5; Plate XVI, 6; Plate XVIII, 6) and representatives of the Ancyrochitina aculeata complex (Plate XII, 1; Plate XIII, 8; Plate XIV, 2). It must be noted that the lowest record of Cutichitina minivelata sp. nov. in the Baq'a-3 core hole does not represent the FAD of this species, which already occurs sporadically, but with higher relative abundances in older strata in the Qusaiba-1 core hole (Fig. 6; Table 19). Specimens resembling Cingulochitina species at $350.1 \mathrm{ft}$ (Plate XIII, 2) and at $330.4 \mathrm{ft}$ are tentatively identified Armoricochitina? sp. (1\% to $3 \%$ of the recorded individuals) (Fig. 8; Table 21). 
Range. The crassicarinata local subbiozone is documented from $408.7 \mathrm{ft}$ to $330.4 \mathrm{ft}$ in the Baq'a-3, i.e. over $78.3 \mathrm{ft}$ (ca. $24 \mathrm{~m}$ ) of depth in the borehole (Fig. 8; Table 21). Due to the spacing of the samples, an interval of uncertainty of $23 \mathrm{ft}(7 \mathrm{~m})$ exists both for the FAD and LAD of A. crassicarinata and thus this subbiozone could range over at maximum of $125.7 \mathrm{ft}$ (ca. $38 \mathrm{~m}$ ) in this core hole.

If one accepts the synonymy proposed here between $A$. crassicarinata sp. nov. and Armoricochitina? n. sp. A in Paris (1993), A. crassicarinata ranges from 3517.4-3623.6 ft (1070-1072 m; cuttings) to $3609.1 \mathrm{ft}$ (1098 m; lowest processed sample in core 1) in well ISWH EW-9 (fig. 2 in Paris, 1993). Consequently, A. crassicarinata ranges at least over 91.7 $\mathrm{ft}(28 \mathrm{~m})$ in the ISWH EW-9 borehole, where its total range is probably closer to $131 \mathrm{ft}$ (ca. $40 \mathrm{~m}$ ), if one considers the position of its acme in Baq'a-3 and in ISWH EW-9.

Age assignment. A. crassicarinata is a new species and therefore, on itself, it does not provide an independent age control. Its location in the upper part of the macclurei regional Biozone supports an early Telychian age (see discussion above for the macclurei Biozone). At least the middle part of the crassicarinata subbiozone is tied to the turriculatus s.l. graptolite Biozone identified at $367 \mathrm{ft}$ in the Baq'a-3 core hole (Zalasiewicz et al., 2007, fig. 5). Early Telychian graptolites (turriculatus s.l. Biozone) are recorded in the upper part of the crassicarinata subbiozone at $336 \mathrm{ft}$ in the Baq'a-3 core hole. It must be noted that no typical A. macclure $i$ were recorded in well ISWH EW-9, and thus the uppermost range of $A$. crassicarinata could extend slightly above the LAD of A. macclurei in this latter well.

\subsection{The Tanuchitina obtusa Biozone}

Definition. This regional biozone corresponds to the interval-range biozone between the LAD 
of Armoricochitina crassicarinata sp. nov. (i.e., equivalent to the FAD of Plectochitina jacquelineae sp. nov.) and the FAD of Euconochitina silurica (Taugourdeau, 1963). It must be noted that T. obtusa has its FAD within the upper part of the macclurei Biozone. Considering the isolated record of a single specimen at $150.4 \mathrm{ft}$, the LAD of T. obtusa is within the succeeding silurica regional Biozone.

Main components. Tanuchitina obtusa (Taugourdeau and de Jekhowsky, 1960), the index species of this regional biozone, is a long chitinozoan (vesicle length ranging usually from $350 \mu \mathrm{m}$ to $450 \mu \mathrm{m}$ ) with gently tapering straight flanks (Plate XIII, 4-5; Plate XV, 2; Plate XVI, 6; Plate XVIII, 6). It has sporadic occurrences and the recorded relative abundances do not exceed $10 \%$ (Fig. 8). Among the most common species is Plectochitina longicornis (Taugourdeau and de Jekhowsky, 1960) (Plate XVI, 7), which may represent up to $20 \%$ of the recorded species (Fig. 8; Table 21). This species has been previously reported from well ISWH EW-9 under the name $P$. paraguayensis "form B". It was recorded in cuttings from $3247 \mathrm{ft}$ to $3594.9 \mathrm{ft}$ (990 m to $1096 \mathrm{~m})$, but not from core 1 at $3586.7 \mathrm{ft}$ to $3601.4 \mathrm{ft}$ (1093.5 $\mathrm{m}$ to $1098 \mathrm{~m}$ ), so caving can be suspected for occurrence in the deeper cutting samples. In the discussion of P. paraguayensis Wood and Miller, 1991, Paris (1993) noted the great similarity between his "form B", P. longicornis and P. nodosa (the latter is herein regarded as a synonym of $P$. longicornis) but he did not assign this "form B" to P. longicornis for stratigraphical reasons. In Algeria, the type material of the two species was from cuttings located above an upper Silurian core sample. Recent investigations (F. Paris unpublished) have not recorded $P$. longicornis or any morphologically similar forms in the late Silurian or in the Early Devonian of Algeria. Because a few sample mixing is proved in some of the older Saharan studies, a wrong location is also suspected for the type sample of P. longicornis, which may as well be of early Silurian age. In spite it is a nomen dubium the species name 
longicornis is however used here. Plectochitina alisawyiahensis sp. nov. is still present in this biozone but its relative abundance is much lower ( $4 \%$ or less) than in the underlying macclurei Biozone. The long ranging $P$. deichaii is again fairly abundant (15\% at $250.5 \mathrm{ft}$ ) as well as other taxa, with sporadic occurrences, e.g. C. minivelata sp. nov. or A. gr. aculeata. Spectacular forms with an unusually well-developed membrane joining the proximal part of the broken processes are tentatively identified as $P$. cf. alisawyiahensis (Plate $\mathrm{XV}, 6)$ and as Anthochitina? sp. A new species, Plectochitina jacquelineae sp. nov. is restricted to the sample at $306.0 \mathrm{ft}$ (Fig. 8; Table 21), i.e. at the base of the obtusa Biozone as defined above. Other interesting species are recorded in the biozone, e.g. Plectochitina lucasi sp. nov. (Plate $\mathrm{XV}, 3,7$ ), which is dominant in the lower part of the obtusa Biozone (see below the definition of the lucasi subbiozone) and Armoricochitina gengi sp. nov. (Plate XV, 1), which represents only $3 \%$ of the chitinozoans recorded at $250.5 \mathrm{ft}$ (Fig. 8; Table 21). A. gengi sp. nov. was reported as Armoricochitina n. sp. aff. panzuda (see Paris, 1993; pl. 2, fig. 3a-b) in cuttings from well ISWH EW-9. In this well, it ranges from $3247 \mathrm{ft}$ to $3568.6 \mathrm{ft}$ (990 m to $1088 \mathrm{~m}$ ) (the deepest records were possibly the result of caving). The striking occurrence of a large number (39\% of the recorded chitinozoans at $206.9 \mathrm{ft}$; Fig. 8; Table 21) of Cyathochitina neolatipatagium sp. nov. in the upper part of the obtusa Biozone must be noted. A similar "bloom-like" event of this species was recorded in Qusaiba-1 within a short interval of less than $1.5 \mathrm{~m}$ thick in the upper part of the hemeri regional Biozone. Such bio-events are puzzling because they have no clear biostratigraphical explanation (Männil, 1971). They likely result from recurrent peculiar environmental conditions, which were specifically favourable for the Cyathochitina producers. A few C. neolatipatagium sp. nov. occur in core 1 of well ISWH EW-9 (not listed in Paris, 1993).

Range. The interval-range of T. obtusa extends for $99.1 \mathrm{ft}$ depth (ca. $30 \mathrm{~m}$ ) from $306.0 \mathrm{ft}$ to 
$206.9 \mathrm{ft}$ in the Baq'a-3 shallow core (Figs. 8-9). Due to the sample spacing an interval of uncertainty respectively of ca. $20.3 \mathrm{ft}$ and $14.4 \mathrm{ft}(6.2$ and $4.4 \mathrm{~m})$ exists on the lower and upper limit of the biozone. In the ISWH EW-9 well, the obtusa Biozone occurs over $164 \mathrm{ft}$ (ca. $50 \mathrm{~m}$ ), and possibly more as the youngest cutting sample at 3254.1-3287 ft (990-1000 mstill contains A. gengi sp. nov. but not Euconochitina silurica, which is the index species of the succeeding biozone. In the ISWH EW-9 well, the obtusa Biozone as defined here corresponds to "Assemblages 3 and 4" of Paris (1993, fig. 2), whereas "Assemblages 1 and 2" correspond to the crassicarinata subbiozone in the terminal part of the macclurei regional biozone (Fig. 9).

Age assignment. None of the species recorded in the obtusa Biozone provide accurate chronostratigraphical information. The absence of early Sheinwoodian chitinozoans, such as Margachitina margaritana, suggests that the obtusa Biozone still belongs to the Telychian, and probably to the mid to late Telychian, as graptolites (turriculatus s.l. Biozone) are still present at $303 \mathrm{ft}$. The graptolites, and especially the retiolitids recovered in the palynological residue from $229.7 \mathrm{ft}$ in Baq'a-3 should give a better tie with the standard graptolite zonation of the Telychian. The obtusa Biozone is at present tentatively correlated with levels within the griestoniensis to spiralis graptolite zones.

\subsection{The Plectochitina jacquelineae sp. nov. subbiozone}

Definition. This local subbiozone corresponds to the total range of Plectochitina jacquelineae sp. nov. The index species is only reported at $306.0 \mathrm{ft}$, in the sample yielding the last abundant A. macclurei. This is also the lowest available sample immediately above the top of the macclure $i$ interval-range Biozone. In spite of the fact that it is restricted to a single sample 
in the Baq'a-3 core hole (Fig. 8; Table 21), this subbiozone is defined because Plectochitina jacquelineae sp. nov. has a distinctive morphology and is easy to identify, even on poorly preserved specimens (Plate XIV, 4, 6).

Main components. Plectochitina jacquelineae sp. nov. occurs with all the major components recovered from the upper part of the macclure $i$ Biozone, i.e. the index species itself, $A$. gr. aculeata, T. obtusa, P. alisawyiahensis sp. nov., C. minivelata sp. nov. (dominant in the assemblage with $37 \%$ of the recorded individuals) and the youngest recorded $C$. densa and $C$. caputoi (Fig. 8; Table 21).

Range. During the present study, Plectochitina jacquelineae sp. nov. has been recorded only from a single sample at depth $306.0 \mathrm{ft}$ in the Baq'a-3 core hole. Due to the spacing of the available samples, an uncertainty of ca. $23.1 \mathrm{ft}(7 \mathrm{~m})$ exists theoretically on its real LAD and FAD in Baq'a-3 (Fig. 8; Table 21). According to the synonymies proposed here, Plectochitina jacquelineae sp. nov. is also represented in the Qusaiba Member of the ISWH EW-9 well (Paris, 1993) and of the Tabuk and Qasim areas (McClure, 1988).

Age assignment. Plectochitina jacquelineae sp. nov. is a new species, and thus cannot be used for independent dating of this subbiozone. In the Baq'a-3 core hole, however, Plectochitina jacquelineae sp. nov. occurs with graptolites of the turriculatus s. 1. Biozone indicating an early Telychian age for this subbiozone. A similar age is proposed for the corresponding strata in the ISWH EW-9 well.

Fairly closely related forms, such as Anthochitina primula Nestor, 1994, or individuals identified as Ancyrochitina ansarviensis Laufeld (in Nestor, 1994, pl. 1, fig. 7) are known in 
the Adavere regional stage in the Baltic area, i.e., in the upper Telychian according to the correlation proposed by Nestor (1994) and improved by comparisons between graptolites and chitinozoan biozonations (Loydell et al., 1998, 2003, 2010).

\subsection{The Plectochitina lucasi sp. nov. subbiozone}

Definition. The subbiozone corresponds to the total range biozone of Plectochitina lucasi sp. nov. The index species (Plate XV, 3,7) is the dominant species in the lower part of the obtusa Biozone (e.g., $63 \%$ of the recorded individuals at $271.8 \mathrm{ft}$; see Fig. 8). This new species (see Systematic section) has a distinctive silhouette. The processes are hollow and display lambda or multi-rooted proximal ends (Plate XV, 7b). This new species was reported in well ISWH EW-9 in open nomenclature as "Ancyrochitina n. sp. B" (see Paris, 1993; pl. 2, figs. 1-2).

Main components. The accompanying species are the long ranging $P$. deichaii, and shorter ranging species, e.g. Plectochitina alisawyiahensis sp. nov., C. minivelata sp. nov., A. gr. aculeata, and T. obtusa (see Fig. 8 and description of the obtusa Biozone above).

Range. P. lucasi sp. nov. occurs from $289.1 \mathrm{ft}$ to $250.5 \mathrm{ft}$, i.e. at least over $38.6 \mathrm{ft}(11.7 \mathrm{~m})$. Due to the sample spacing, an interval of uncertainty of respectively $16.9 \mathrm{ft}(5.15 \mathrm{~m})$ and 20.8 $\mathrm{ft}(6.3 \mathrm{~m})$ exists for the base and the top of the lucasi subbiozone in the Baq'a-3 shallow core (Fig. 8; Table 21).

If one accepts the synonymy proposed here between $P$. lucasi sp. nov. and "Ancyrochitina n. sp. B" in Paris (1993), it ranges in the ISWH EW-9 well in cuttings samples from $3470.2 \mathrm{ft}$ to $3588.3 \mathrm{ft}$ (1058 to $1094 \mathrm{~m})$. Thus, it range is over $118 \mathrm{ft}$ (36 m; see Fig. 9), and likely less 
because the deepest individuals could be caved, as they occur within the upper range of $A$. crassicarinata in “Assemblage 2" of Paris (1993). The absence of $P$. lucasi sp. nov. in core 1 (1993.5 to $1098 \mathrm{~m}$ ) in the ISWH EW-9 well confirms this interpretation.

Age assignment. No graptolites are recorded in the samples yielding P. lucasi sp. nov. Moreover, the chitinozoan species recorded in the lucasi subbiozone do not allow direct correlation with the early Silurian chronostratigraphy. Thus the same arguments as for the obtusa Biozone are used for determining the age of the lucasi subbiozone. The absence of Margachitina margaritana, a widespread early Sheinwoodian chitinozoan, is regarded as an argument for keeping the lucasi subbiozone in the Telychian.

\subsection{The Euconochitina silurica Biozone}

Definition. This biozone corresponds to the total range biozone of Euconochitina silurica (Taugourdeau, 1963). The LAD of the index species is not documented in the processed material (no sample available above $130 \mathrm{ft}$ in the Baq'a-3 core hole). Taugourdeau (1963) defined E. silurica in a core sample from the eastern part of the Illizi Basin, SE Algerian Sahara (sample at $1445 \mathrm{~m}$ depth in well Zr. 1). The original name was Conochitina oelandica subsp. silurica. This subspecies is raised here to species rank because of its discriminating characters. E. silurica is a very small chitinozoan (Plate XVIII, 3-4), which has a total length ranging around $90-110 \mu \mathrm{m}$ in the investigated samples. It displays a conical chamber with a rounded margin. The sub-cylindrical neck may represent half to one third of the vesicle length. The vesicle wall is smooth; a small scar occurs on the apex of the vesicle (Plate XVIII, 4). 
Main components. Several taxa present in the underlying biozones range into this biozone (Fig. 8; Table 21). They include the highest occurring specimens of P. deichaii, as well as representatives of $P$. alisawyiahensis sp. nov. The latter may be fairly abundant (e.g., $18 \%$ of the recorded specimens at $150.4 \mathrm{ft}$ ), Calpichitina cf. acollaris (Plate XVII, 6, 8) and $C$. minivelata sp. nov., which has a surprisingly high relative frequency (62\%) at $192.5 \mathrm{ft}$, when E silurica has its FAD (Fig. 8; Table 21). Other species range into the silurica Biozone. Armoricochitina gengi sp. nov. (Plate XVII, 1-2) dominates the assemblage (42\% of the recorded individuals) at $150.4 \mathrm{ft}$, whereas another form, tentatively identified as Fungochitina? sp. (Plate XVII, 3-5), is the most abundant form (51\%) at $170.9 \mathrm{ft}$ (Fig. 8; Table 21). Fungochitina? sp. has a fungiform chamber, which may be variously modified during lateral compression of the vesicle (e.g., Plate XVII, 4). The walls bear granules to small spines. The most striking element, however, is the very short and irregular rim-like structure (remains of a carina?) running around its rounded margin. To some extent, such structure recalls the short carina of Anthochitina jawfensis Al-Hajri and Paris, 1998 from the Sharawra Member of the Qalibah Formation. The preservation of this possible carina is too poor and the form is therefore provisionally referred to Fungochitina, rather than to Anthochitina. E. silurica dominates the highest investigated chitinozoan assemblage at $130 \mathrm{ft}$ (79\% of the recorded individuals), where it coexists with a form tentatively referred to Plectochitina cf. lucasi sp. nov. The specimens recorded at $130 \mathrm{ft}$ differ slightly from the population of $P$. lucasi sp. nov. observed in the preceding obtusa Biozone (see discussion below in the Systematic section). P. cf. lucasi sp. nov. (Plate XVIII, 1b, 2b) possesses also a conical chamber and a very long neck flaring close to the aperture but the walls are covered with randomly distributed granules and the processes are shorter than in the typical populations of $P$. lucasi sp. nov. 
Range. The silurica regional Biozone occurs from 192.5 to $130.0 \mathrm{ft}$, in the upper $62.5 \mathrm{ft}$ (19 m) of the Baq'a-3 core hole. This interval thickness must be regarded as a minimum as the relative abundance of the index species is very high in the last processed sample and the biozone most likely extends into younger strata not investigated here. The stratigraphic range of the index species is unknown in its type locality in Algeria, which is based on an isolated sample.

Age assignment. The silurica regional Biozone, like the preceding ones, does not contain chitinozoan species permitting an independent age assignment. Again, the absence of Margachitina margaritana, which has a FAD that is well-constrained in British sections (Mullins and Loydell, 2001) and in Baltoscandian sections (Nestor, 1994; Loydell et al., 2003, 2010), is used here for tentatively dating the silurica Biozone as pre-Sheinwoodian. No graptolite remains have been observed from the samples yielding E. silurica. This may result from too shallow-water environments in the uppermost part of the Qusaiba Member as indicated by the abundance of eurypterid remains in the organic residue (Silurian eurypterids are usually regarded as near-shore organisms). The occurrence of retiolitid graptolites just below the base of the silurica Biozone is compatible with a late Telychian age for this biozone (possibly within the time interval corresponding to the spiralis to centrifugus graptolite zones). The silurica Biozone is here regarded as a faunal indicator of the upper part of the Qusaiba Member, close to its boundary with the Sharawra Member.

\section{Chronostratigraphy of the Qusaiba Member}

One informal assemblage (“Assemblage 1" in Paris et al., this volume) and six chitinozoan 
biozones have been identified in the investigated samples from the Qusaiba-1, Baq'a-4 and Baq'a-3 core holes. In ascending order are the qusaibaensis (pro parte), alargada, hemeri, macclurei, obtusa and silurica biozones. These biozones are considered of regional value, i.e. usable in the northern Gondwana regions (north and west Africa, southern parts of Europe, the Arabian Plate and western Iran). In addition, five subbiozones of more local value (Arabian Plate or beyond) are proposed (Fig. 9). One characterises the upper part of the hemeri Biozone (the camilleae subbiozone). Two other biostratigraphic subdivisions (the merrelli and the crassicarinata subbiozones) are part of the macclurei Biozone. The two remaining (jacquelineae and lucasi subbiozones) occur within the obtusa Biozone.

The chitinozoans recorded in the lowermost part of the Qusaiba Member in the Qusaiba-1 core hole, permit identification of a distinctive early Rhuddanian chitinozoan assemblage (“Assemblage 1" in Paris et al., this volume). No formal biozone name is proposed for this assemblage located immediately above the top of the Sarah Formation (Figs. 3 and 6) because apart from B. pseudarabiensis it does not contain key chitinozoan species of the lower Llandovery chitinozoan biozonation. Nevertheless, based on similar chitinozoan assemblages coexisting with early Rhuddanian graptolites in other northern Gondwana localities, the association with dominant $C$. caputoi and B. pseudarabiensis is considered diagnostic of the basalmost Silurian (see discussion in Paris et al., this volume). Because the immediately overlying strata yield chitinozoans of the qusaibaensis Biozone associated with graptolites of the convolutus graptolite Biozone, a significant hiatus (most of the Rhuddanian and Aeronian pro parte) is recognized in the lower part of the Qusaiba Member (core 27 at $254.5 \mathrm{ft}$; Fig. 6).

Whenever the sedimentary record is complete, the qusaibaensis interval-range Biozone originates in the upper Rhuddanian and ends in the early mid-Aeronian. In the Qusaiba-1 
shallow core, only the upper part of the qusaibaensis Biozone corresponding to the convolutus graptolite Biozone pro parte (Zalasiewicz et al., 2007) is represented in cores 27 (upper part) and 26. This upper part of the qusaibaensis is well characterized by Muscochitina olivieri sp. nov. a taxon also recovered in core 20 in the TINT- 2 well and in core 17 of the UDYN-1 well.

In the Qusaiba-1 core hole, the alargada interval-range Biozone reported from cores 25 to 22 is assigned to the middle Aeronian, based on the combined occurrence of the chitinozoans with graptolites of the lower part of the convolutus Biozone (Fig. 9).

The hemeri interval-range Biozone is documented in the upper part of the Qusaiba-1 and in the lower part of the Baq'a-4 core holes (Paris, 2003, 2005). This biozone was identified also in deep core samples from eastern Central Saudi Arabia (Paris et al., 1995), e.g. core 17 from UDYN-1 (Paris, 1991) and cores 17-20 from TINT-2 (Paris, 1992). Graptolites of the convolutus Biozone are associated with the chitinozoans of the hemeri Biozone, both in the Qusaiba-1 (cores 22 to 14) and in the Baq'a-4 (cores 31 to 19) wells. These graptolites provide a precise correlation with the middle part of the Aeronian (Zalasiewicz et al., 2007). The camilleae sp. nov. total-range subbiozone is identified in the upper part of the hemeri Biozone, cores 23 to 19 (i.e., middle part of the Baq'a-4 core hole). The mid-Aeronian age assignment of the camilleae subbiozone is based on its direct calibration by graptolites of the convolutus Biozone (Fig. 9).

The macclure i interval-range biozone is identified in the upper part of the Baq'a-4 and in the lower part of the Baq'a-3 shallow cores. The early Telychian graptolites (Zalasiewicz et al., 2007) occurring with the index species in the two shallow cores provide a precise and independent calibration of this biozone. Its lower part is represented in cores 17 to 7 (i.e. from 
140.6 to $40.1 \mathrm{ft}$ ) of the Baq'a-4 well, where the chitinozoans of the macclurei Biozone occur with graptolites of the guerichi Biozone. The middle and upper part of the biozone is documented from the lower part (cores 56 to 36, i.e. from $518.3 \mathrm{ft}$ to $330.4 \mathrm{ft}$ ) of the Baq'a-3 core hole. In this well, the chitinozoans are associated with graptolites of the turriculatus s.l. Biozone in core 40 (367 ft), and in cores 34 and 36 of early Telychian age (Fig. 9). The macclurei Biozone was originally defined in core 16 of TINT-2 well and tentatively attributed to the late Telychian (Paris et al., 1995). The present data indicate that this previous dating must be corrected. The macclurei Biozone range is restricted to the lower Telychian. The merrelli sp. nov. total-range subbiozone is identified in cores 15 to 7 from the uppermost part of the Baq'a-4 well and from cores 49 and 47 from the lower part of the Baq'a-3 well. This subbiozone, which represents the lower part of the macclurei Biozone, has been documented in other Saudi Arabian wells. It is assigned to the early Telychian as it is bracketed by graptolites of the guerichi and turriculatus biozones (Fig. 9).

The crassicarinata sp. nov. total-range subbiozone is identified in cores 45 to 36 (from 408.7 $\mathrm{ft}$ to $330.4 \mathrm{ft}$ ) from the middle part of the Baq'a-3 core hole. This subbiozone is wellrepresented the ISWH EW-9 well (core 1, and cuttings corresponding to "Assemblage 2" in Paris, 1993). The subbiozone is most likely present in the upper part of core 16 from the TINT-2 well after a reappraisal of the less well-preserved individuals, unnamed in Paris (1992). The crassicarinata subbiozone is assigned to the early Telychian based on a direct graptolite calibration in the Baq'a-3 core hole where the crassicarinata subbiozone occurs with graptolites (M. e.g. gr. marri at $367 \mathrm{ft}$ and $S$. becki at $336 \mathrm{ft}$ ). Zalasiewicz et al. (2007, fig. 5) referred these graptolites to the turriculatus s.l. Biozone (Fig. 9).

The obtusa interval-range Biozone is identified in the upper part of the Baq'a-3 well (cores 34 to 22 , i.e. from $306.0 \mathrm{ft}$ to $206.9 \mathrm{ft}$ ), and in core 1 and cuttings samples from $3293.1 \mathrm{ft}$ (1004 
m) to $3509.6 \mathrm{ft}(1070 \mathrm{~m})$ from ISWH EW-9. In terms of graptolite zones, no direct calibration of the obtusa Biozone is presently available in Saudi Arabia or in other northern Gondwana regions (e.g. Algeria, Spain). Tentatively, a mid- to late Telychian age assignment is proposed here based on indirect evidence, as the obtusa Biozone is recorded above early Telychian strata and does not contain the Sheinwoodian chitinozoans known in other northern Gondwana localities (Fig. 9).

The Plectochitina jacquelineae sp. nov. subbiozone is restricted to core 34 (306.0 ft) in the Baq'a-3 core hole. This taxon ranges briefly in cuttings from $3299.7 \mathrm{ft}$ to $3509.6 \mathrm{ft}$ (1006 to $1070 \mathrm{~m}$ ) and in core 1 (at $1093.5 \mathrm{~m}$, i.e. $3586.7 \mathrm{ft}$ ) in the ISWH EW-9 well. Based on graptolite evidences (graptolites of the turriculatus s.l. Biozone recorded up to $303 \mathrm{ft}$ in Baq'a-3; Zalasiewicz et al., 2007) the subbiozone also can be attributed to the lower Telychian. Core 34 from the Baq'a-3 well and the cuttings from the ISWH EW-9 are therefore tentatively assigned to the lower Telychian.

The lucasi sp. nov. total-range subbiozone occurs from core 32 to core 27 (from $289.1 \mathrm{ft}$ to $229.7 \mathrm{ft}$ ) in the middle part of Baq'a-3. The lucasi subbiozone is also documented in ISWH EW-9 well where the index species occurs in "Assemblage 3" sensu Paris (1993) in cuttings from $3470.5 \mathrm{ft}$ to $3509.6 \mathrm{ft}$ (1058 to $1070 \mathrm{~m})$. In the ISWH EW-9 well the specimens recorded below in the borehole are possibly caved. The lucasi subbiozone is tentatively attributed to the middle and/or upper Telychian as it occurs just above samples yielding graptolites of the turriculatus s.l. Biozone (Fig. 9).

The silurica total range Biozone is identified in cores 21 to 14 from the uppermost part (192.5 $\mathrm{ft}$ to $130.0 \mathrm{ft}$ ) of the Baq'a-3 well. Its upper part is not documented in this shallow core (no samples processed above core 14). The silurica Biozone is known in other northern 
Gondwana regions, e.g. in SE Algeria. The shallow environments of the Sharawra Member, which extends above core 14 in the Baq'a-3 well, seem unfavourable for graptolites. Therefore, this fossil group will be of no help for dating the upper part of the silurica Biozone. This biozone is tentatively attributed to the late Telychian (Fig. 9) because no typical early Sheinwoodian chitinozoans, known to occur elsewhere in the Sharawra Member (Al-Hajri and Paris, 1998), are observed in this biozone.

\section{Qusaiba environments and chitinozoan taphonomy}

The abundance of the recorded chitinozoans in each sample of the three investigated wells has been collated with the lithology of the processed material (Tables 1-3) in order to depict possible relationships between the lithology and the abundance of the chitinozoans. The lithology is fairly constant through the investigated part of the Qusaiba Member dominated by greenish to grey shale. With the exception of the carbonaceous shale at $254.8 \mathrm{ft}$ and of a thin sandy bed (254.5 ft to $253.5 \mathrm{ft}$ ) in the Qusaiba-1 core hole, only minor lithological variations are noticed, especially increases of the silt fractions (e.g., at $330.4 \mathrm{ft}$ and $306.0 \mathrm{ft}$ in Baq'a-3, or at $60.1 \mathrm{ft}$ and $40.1 \mathrm{ft}$ in Baq'a-4) or the occurrence of silty to fine sandy laminae (e.g., at 132.05 ft in Qusaiba-1, at $130.0 \mathrm{ft}$ in Baq'a-3, and at $269.0 \mathrm{ft}$ or $240.7 \mathrm{ft}$ in Baq'a-4). The most significant increase of the grain size is noted in core 14 (130.0 ft) in Baq'a-3. There is not an obvious relation between the grain size or the colour of the sediment when compared to the abundance of the chitinozoans (expressed in specimens per gram of rock). One would expect to have the highest abundances in the shaly facies. The highest recorded values are in core 14 from Qusaiba-1, respectively at $140.1 \mathrm{ft}$ in the grey greenish shale (3920 chitinozoans per gram of rock) and at $136.5 \mathrm{ft}$, in the grey greenish siltstone (3080 chitinozoans per gram 
of rock). In the latter well, the most evident trend is an increase in the chitinozoan abundances through time, independently of the colour of the sediment. This high chitinozoan production drops significantly in the uppermost part of the well (core 14), in more silty deposits (at $133.45 \mathrm{ft}$ ) or deposits with sandy laminae (132.05 ft). In this core hole, eurypterid fragments occur exclusively in these two samples and a temporary shallowing is interpreted. A similar, but more conspicuous and sustained trend is also recorded in the upper part of the Baq'a-3 core hole. In this well, a correlation between a lowering of the chitinozoan abundances and the occurrence of eurypterid remains is also noticed (Table 3). A shallowing trend announcing the nearshore environments of the overlying Sharawra Member is registered in the upper part of this core hole, particularly in core 14 with the grey siltstone and sandy laminae at $130.0 \mathrm{ft}$. This sample has by far the lowest chitinozoan abundance (27 specimens per gram of rock) among the processed samples in the three investigated core holes.

To summarize, the chitinozoan abundances do not exactly reflect the lithology, as shale or siltstone samples can yield more than 9000 chitinozoans per gram of rock but conversely these two types of sediment may contain less than 100 chitinozoans per gram of rock. The most obvious limiting factor for the proliferation of most of the chitinozoan species seems to be the shallow water depositional environments. On the contrary for some species such as $C$. neolatipatagium sp. nov., these environments seem to be the most suitable (see below). The highest abundances (exceeding 9000 chitinozoans per gram of rock Table 1) are in environments leading to condensed sequences (see Melvin, this volume), e.g. the highly bioturbated carbonaceous dark shale at $254.8 \mathrm{ft}$ in the Qusaiba-1 core hole (see Melvin, this volume).

Independently of the recorded chitinozoan abundances, slight discrepancies are noted in the 
detailed range of some species within the Saudi Arabian Silurian sequences (Figs. 6-8). They may be partly related to sporadic occurrences and/or to the spacing of the samples. Most of these discrepancies, however, result from an environmental control on the distribution of peculiar chitinozoan species. Several taxa such as Plectochitina alisawyiahensis sp. nov. seem to be better represented in fine-grained deposits (see Table 3 and Fig. 8), possibly due to their delicate ornamentation. Such low energy depositional settings are also required for the preservation of thin-walled delicate structures as the "sleeve" extended externally from the prosome of A. qusaibaensis. The fragile aggregates of crushed Cyathochitina recorded at $245.8 \mathrm{ft}$ in the Qusaiba-1 well, and interpreted as coprolites, may have survived because they were produced in situ in the sediment (occurrence of small internal bioturbation). Other species are representative of open and deeper marine environments e.g. Angochitina hemeri, Angochitina macclurei. They are the dominating taxa in the less diversified assemblages recorded in the TINT-2 well, corresponding likely to a more distal environment setting. The slight lithological changes observed in the Baq'a-3 and Baq'a-4 core holes, however, have no real impact on the abundance of A. macclurei (Tables 2-3 and Figs. 7-8). Species such as Cyathochitina neolatipatagium sp. nov. (at $206.9 \mathrm{ft}$ in the Baq'a-3 and in core 14 in Qusaiba1 core holes) or even Cyathochitina caputoi have more intermittent occurrences recalling the distribution of opportunistic taxa, with bloom-like occurrences (i.e., sudden and brief proliferation, with a "Lazarus" distribution). The temporary absence of specific predators may also explain the sudden proliferation of some chitinozoan species (see discussion in Grahn and Paris, 2011). C. neolatipatagium sp. nov. seems dependent on the more shallow siltier environments in Qusaiba-1 (see Table 1 and Fig. 6) and Baq'a-3 (Table 3, Fig. 8). Consequently, when selecting the index species of biozones (or subbiozones) and when proposing correlation between different sections or wells, we have paid much attention to examine how far the acme biozone of a species reflects the optimal development of a species 
or results from a "bloom-like" proliferation driven by local optimal environmental conditions.

\section{Conclusions}

The chitinozoan assemblages recovered from the Qusaiba Member of the Qalibah Formation penetrated by the Qusaiba-1, the Baq'a-4 and the Baq'a-3 core holes are extremely diverse and contain abundant and well-preserved chitinozoans. These shallow cores allowed overcoming of the effects of the deep weathering that affects the outcrop samples and precludes the use of palynomorphs for their dating. The present data permit establishing a precise biozonation for the chitinozoans in the material from the type area of the Qusaiba Member and from the neighbouring Baq'a area. The identified biozones provide excellent correlation with the subsurface sequences of the central and north-eastern parts of Saudi Arabia. Direct calibration by associated graptolites allows precise age assignment in terms of the standard graptolite biozones and of Silurian stages.

A significant hiatus representing most of the Rhuddanian and the lower part of the Aeronian is documented in the lower part of the Qusaiba Member in the Qusaiba-1 core hole. The hiatus is located above the basal part of the Qusaiba Member, which yields very abundant earliest Rhuddanian chitinozoans immediately above the last glacially related Baq'a Sand Member of the Sarah Formation (see discussion in Paris et al., this volume). This hiatus corresponds either to a gap (but no erosion or palynomorph reworking is observed) or to a highly condensed sequence as suggested by the abundant bioturbation developed in a thin sandy bed above the hiatus. The main part of the Qusaiba Member was deposited in open and low energy marine environments as demonstrated by the preservation of very delicate 
structures in the chitinozoans (e.g., "sleeve" of A. qusaibaensis, clusters of A. macclurei, coprolites consisting of fragmented Cyathochitina).

The shallowing trend preceding the more nearshore environments of the Sharawra Member is registered by a decrease in diversity and abundance of the chitinozoans, but also by an increase in the eurypterid remains within the organic residue.

The investigations carried out on the Qusaiba Member have revealed a biodiversity of the chitinozoans through time much higher than documented previously. This allowed to describe numerous new species in the present paper. It is clear that the former published studies missed some important intervals. This was mainly due to a discontinuous and too scattered sampling of the Qusaiba sequence. One can expect now chitinozoan correlation at the scale of the Arabian palaeoplate with accuracy close to or in a few cases even more detailed than that of graptolites from this Qusaiba Member. For a long time the Saudi Arabian chitinozoan biozones suffered of a deficit of precise calibration with regard to the Silurian standard chronostratigraphy. The present study contributes significantly to improvement of the available dating in terms of Llandovery stages, thanks to the excellent ties provided by the graptolites coexisting with the chitinozoans in the upper part of the Qusaiba Member. This study indicates also that a single section is not sufficient for elaborating a regional biostratigraphic model when the geological context (major rapid transgression, or glaciation) is susceptible to generate condensed sequences or gaps of various magnitudes.

\section{Appendix A. Main lithological and palaeontological data concerning the processed} samples (Tables 1-3) 


\section{Appendix B. Systematic palaeontology (F. Paris)}

The classification and the terminology proposed by Paris et al. (1999) are used for the description of the new chitinozoan species defined in the Systematic section. The measurements of the morphological parameters are expressed in micrometres $(\mu \mathrm{m})$ and the abbreviations defined by Paris (1981) are used i.e., total length (L), chamber diameter (Dp), neck diameter (dc), collarette diameter (dcoll.), collarette length (lcoll.), neck length (lc). Biometric graphs give the size variations for each of the new species. The choice of holotypes with measurements close to the average values of the measured populations is favoured (Figs. 10-24). For the measurements, a correction of the compression of the vesicle is used depending on the importance of the flattening, e.g. coefficient of 0.8 for the chamber (usually less affected because its thicker wall near the margin) and coefficient of 0.7 for the neck and the collarette (thinner wall and thus frequently totally compressed).

The sorted specimens and the individuals observed under a Scanning Electron Microscope (SEM) are housed in the palynological collections of the Geological department of Rennes University, France (Géosciences, OSUR), with the repository numbers IGR 72251 to 72376. The coordinates of illustrated specimens are given using the England-Finder Grid.

Incertae sedis Group Chitinozoa Eisenack, 1931

Order Prosomatifera Eisenack, 1972

Family Conochitinidae Eisenack, 1931, emend Paris, 1981 
Subfamily Conochitininae Paris, 1981

Genus Conochitina Eisenack, 1931 emend Paris et al., 1999

Type species: Conochitina claviformis Eisenack, 1931

Conochitina viiuae sp. nov. Paris (Plate I, 2; Plate II, 4-5)

v. 1985 - Conochitina proboscifera Eisenack, 1937; Molyneux and Paris, pl. 14, figs. 1a-b.

Derivation of the name: this species is dedicated to Viiu Nestor for her outstanding investigations on the Silurian chitinozoans from the Baltic area.

Holotype: Plate II, 5, core 26, 245.8 ft, IGR 72256 (M44/4).

Type locality: Qusaiba-1 core hole, North Central Saudi Arabia.

Type stratum: Qusaiba Member of the Qalibah Formation; core 26, sample from $245.8 \mathrm{ft}$, mid-Aeronian

Paratype: Plate II, 4, core 26, 245.8 ft, IGR 72256 (O44/3).

Material: 33 sorted specimens from core 26 in the Qusaiba-1 core hole but ca. 300 additional individuals in the remaining organic residue.

Diagnosis: Long and slender Conochitina species ( $\mathrm{L} / \mathrm{Dp}>6)$ with an elongate claviform to sub-cylindrical chamber; long neck flaring near the aperture; vesicle walls perfectly smooth; rounded margin; convex to truncate ogival bottom with a large protruding mucron.

Description: The total length of this very long and slender chitinozoan (mean vesicle length: ca. $425 \mu \mathrm{m}$; length of the holotype: $522.6 \mu \mathrm{m}$ ) shows important variations (see Table 4; Figs. 
10a-b) with $\mathrm{L}$ ranging in the measured specimens from ca. $310 \mu \mathrm{m}$ (collarette missing) to $686.7 \mu \mathrm{m}$ (Plate II, 4). The narrow chamber has gently tapering straight flanks (Plate II, 4) or a drawn out claviform profile (Plate II, 5). No flexure or shoulder is present at the junction between the chamber and the long cylindrical neck, flaring near the aperture. The average ratio of the vesicle length (L) on chamber diameter (Dp) is ca. 7.6, and may exceed 10 (e.g., paratype, Plate II, 4). The length of the chamber is close to the length of the neck. A long prosome, usually with numerous septa, is located deeply in the neck. The lower part of this prosome (likely more robust) is frequently less flattened than the remaining part of the neck. The resulting differential flattening simulates a constriction in the middle part of the vesicle (Plate II, 4-5). The walls are perfectly smooth and rather thick, particularly near the margin (holotype not compressed, and thus no coefficient of correction used on Table 4). The bottom of the chamber is convex or has a truncated ogival profile due to the presence of a large circular mucron with a flat top (Plate II, 4b). The diameter of this mucron is close to half the diameter of the chamber.

Measurements (Table 4; Figs. 10a-b).

\begin{tabular}{|c|c|c|c|c|}
\hline & $\mathrm{L}$ & $\mathrm{Dp}$ & Dc & Dcoll. \\
\hline Holotype & 522.6 & (63.4) & $\begin{array}{l}(46.9) \\
* 37.5\end{array}$ & $\begin{array}{l}(57.0) \\
* * 39.9\end{array}$ \\
\hline Mean & 424.5 & $\begin{array}{l}\text { (55.5) } \\
* 44.4\end{array}$ & $\begin{array}{l}(45.3) \\
* 36.3\end{array}$ & $\begin{array}{l}\text { (55.9) } \\
* * 39.1\end{array}$ \\
\hline Maximum & 686.7 & $\begin{array}{l}(93.8) \\
* 75.1\end{array}$ & $\begin{array}{l}(58.7) \\
* 47.0\end{array}$ & $\begin{array}{l}(73.7) \\
* * 51.6\end{array}$ \\
\hline Minimum & 308.2 & $\begin{array}{l}(46.9) \\
* 37.6\end{array}$ & $\begin{array}{l}(33.5) \\
* 26.8\end{array}$ & $\begin{array}{l}(33.5) \\
* 26.8\end{array}$ \\
\hline
\end{tabular}


Table 4: Biometric data (micrometers) for Conochitina viiuae sp. nov. Means are based on 15 partly flattened specimens from the Qusaiba-1 core hole, core 26, at $245.8 \mathrm{ft}$ depth (raw data: between brackets; *correction factor: $0.8 ; * *$ correction factor: 0.7$)$.

Discussion: This new species is a typical Conochitina according the emended definition of this genus given by Paris et al. (1999). The specimen recorded at $251.1 \mathrm{ft}$ (Plate I, 2) is totally compressed and thus its original diameter was ca. $41 \mu \mathrm{m}$ (i.e. within the Dp range of the species; see Table 4). The folded and tilted base obscures its mucron.

Other very elongate Conochitina species $(\mathrm{L} / \mathrm{Dp}>6)$ have already been reported in the Ordovician and in the Silurian. Comparisons, however, are restricted here to Late Ordovician and to Silurian species. Conochitina incerta Eisenack, 1962 from the Late Ordovician of Baltoscandia has a sharper margin and a smaller mucron. Conochitina rotundata sp. nov. Paris et al. (this volume) from the late Katian of the Qusaiba-1 core hole has a sub-cylindrical vesicle and a base with a different shape (see discussion in Paris et al., this volume). Conochitina proboscifera Eisenack, 1937 and even the "forma truncata" described by Laufeld (1974) have much thicker walls and a less slender silhouette. In the Llandovery of well D1-31 in Cyrenaica (eastern Libya) Paris in Molyneux and Paris (1985) identified as $C$. proboscifera a chitinozoan with a silhouette and a mucron very close to those of $C$. viiuae sp. nov. In spite there are no statistical data available for the total length of the Libyan form, it is included in the synonymy of $C$. viiuae, sp. nov. Conochitina alargada Cramer, 1967 has a stouter vesicle and no protruding mucron. Conochitina leptostoma Laufeld, 1974 from the early Wenlock of Gotland has also a slim vesicle, but its mucron is smaller and its flanks taper up to the aperture. Conochitina praeproboscifera Nestor, 1994 is wider (L/Dp ca. 4-4.5) and has a mucron less well-developed than C. viiuae sp. nov (L/Dp>6). Conochitina rara Nestor, 1994 from the Aeronian of Estonia has an anti-apertural end, similar to that of C. viiuae sp. 
nov., but the vesicle is much shorter.

Range and geographic distribution: In the Qusaiba-1 core hole, Conochitina viiuae sp. nov. has been recorded in core $26(245.8 \mathrm{ft})$ where it represents $15 \%$ of the identified chitinozoans. A few less typical individuals are reported at $251.1 \mathrm{ft}$ (Plate I, 2) and at $238.2 \mathrm{ft}$ in the same well (Fig. 6; Table 19). These strata belong to the upper part of the qusaibaensis Biozone, which is assigned to the mid-Aeronian, based on the independent age control provided by graptolites of the convolutus Biozone (Zalasiewicz et al., 2007). This new species is likely rare and has a short range as it has not been reported yet in other subsurface chitinozoan assemblages from the Qusaiba Member. In all likelihood, the species is present (see synonymy) in a core sample from well D1-31 in Cyrenaica, eastern Libya (Molyneux and Paris, 1985; Paris, 1988a).

Subfamily Spinachitininae Paris, 1981

Genus Spinachitina Schallreuter, 1963 emend Paris et al., 1999

Type species: Conochitina cervicornis Eisenack, 1931

Spinachitina geerti sp. nov. Paris (Plate VII, 1, 4-5, 7-8)

? 1988 - Conochitina spp.; McClure, pl. VI, figs. 1-2 (non fig. 3).

1990 - Spinachitina spinosa nomen nudum; Van Grootel, pl. 8, figs. 11-15.

? 1991 - Spinachitina bulmani Jansonius, 1964; Al-Hajri, pl. 25 figs; 1-4 (non figs. 5-6).

v. 1991 - Spinachitina maennili (Nestor, 1980b); Paris, pl. 2 fig. 6a-b. 
v. 1991 - Spinachitina sp. aff. maennili (Nestor, 1980b); Paris, pl. 2 fig. 7a-b.

v. 1995 - Spinachitina maennili (Nestor, 1980b); Paris et al., fig. 2 p. 79.

Derivation of the name: This species is dedicated to Dr Geert Van Grootel who described this species in his doctoral thesis under the name Spinachitina spinosa sp. nov. Unfortunately this species remained unpublished and has to be considered as a nomen nudum (see discussion below).

Holotype: Plate VII, 7, core 28, 240.7 ft, IGR 72371 (P42/4).

Type locality: Baq'a-4 core hole, North Central Saudi Arabia.

Type stratum: Qusaiba Member of the Qalibah Formation; core 28, sample from $240.7 \mathrm{ft}$, Aeronian

Paratypes: Plate VII, 1, core 28, 240.7 ft, IGR 72371 (Q42/1); Plate VII, 4, core 28, 240.7 ft, IGR 72371 (Q41/2); Plate VII, 8, core 28, 240.7 ft, IGR 72371 (Q41).

Material: 25 sorted specimens (ca. 200 additional individuals in the remaining unpicked organic residue).

Diagnosis: Large Spinachitina species with a conical chamber prolonged by a neck flaring near its fringed aperture; crown of well developed spines on the margin; randomly distributed robust spines on the chamber and on the neck; this ornamentation decreases on the chamber bottom and on the neck.

Description: The total length of this quite long chitinozoan (mean length: $252 \mu \mathrm{m}$; length of the holotype: $231 \mu \mathrm{m}$ ) shows important variations (see Table 5; Figs. 11a-b) with L ranging from $322 \mu \mathrm{m}$ (Plate VII, 4) to $141 \mu \mathrm{m}$ (Plate VII, 5; the latter, however is possibly broken or teratological). The general silhouette of the vesicle is rather variable, with a fairly constant chamber width but a highly variable length due principally to the development of the neck. There is a positive correlation between the vesicle length $(\mathrm{L})$ and the chamber length (lp) (Fig. 
11b). Some elongate specimens have a long tubular neck ending with a flaring collarette. The aperture is serrated (Plate VII, 7a). The flanks taper progressively up to the base of the neck, which is separated from the chamber by a poorly differentiated shoulder and by a weak flexure (Plate VII, 1, 4). A slight constriction occurs in the third lower part of the chamber. A sharp margin corresponding to the maximum diameter of the chamber separates a slightly convex bottom from the flanks. The convexity of the anti-apertural end is accentuated by the folding downwards of the chamber bottom during compression (e.g. Plate VII, 7b). This fold usually obscures the apex of the vesicle and thus the antiapertural structure is not welldocumented. A large flat circular area surrounded by a low rim is present (Plate VII, 1). The main discriminating characters of this species are the combination of the crown of fairly long spines running along the margin, and the robust and well-developed spines on the chamber (Plate VII, 1, 7b, 8). The spiny crown is composed of ca. 30 quite long tapering spines (length up to $12 \mu \mathrm{m}$ ), densely and regularly distributed along the margin (Plate VII, 7b, 8) and directed anti-aperturalwards. Robust but shorter conical spines are randomly distributed on the chamber (Plate VII, 7b, 8). This spiny ornamentation fades away toward the neck where they are reduced to granules or to blunt cones. The chamber bottom below the crown surrounding the margin is smooth (Plate VII, 1) or carries small granules (Plate VII, 7b, 8). Measurements (Table 5; Figs. 11a-b).

\begin{tabular}{|l|l|l|l|l|l|l|}
\hline & L & lp & Dp & dc & dcoll. & l. spines \\
\hline Holotype & 231 & 171 & $(68.7)$ & $(55.3)$ & $(57.0)$ & 6.7 \\
& & & $* 55.0$ & $* * 38.7$ & $* * 40.0$ & \\
\hline Mean & 252 & 168 & $(82.4)$ & $(54.6)$ & $(58.3)$ & 5.7 \\
& & & $* 65.9$ & $* * 38.2$ & $* * 40.8$ & \\
\hline Maximum & 322 & 208 & $(101)$ & $(65.3)$ & $(65.3)$ & 10.1 \\
& & & $* 81$ & $* * 45.7$ & $* * 45.7$ & \\
\hline
\end{tabular}




\begin{tabular}{|l|l|l|l|l|l|l|}
\hline Minimum & 141 & 121 & $\begin{array}{l}(53.6) \\
* 42.9\end{array}$ & $\begin{array}{l}(43.6) \\
* * 30.6\end{array}$ & $\begin{array}{l}(43.6) \\
* * 30.6\end{array}$ & 3.5 \\
\hline
\end{tabular}

Table 5: Biometric data (micrometers) for Spinachitina geerti sp. nov. Means are based on 15 compressed specimens from the Baq'a-4 core hole, core 28 at $240.7 \mathrm{ft}$ depth (raw data: between brackets; *correction factor: $0.8 ; * *$ correction factor: 0.7$)$.

Discussion: Van Grootel (1990, p. 78-80) described a chitinozoan he named Spinachitina spinosa sp. nov. from the subsurface of the Brabant Massif (Belgium). Unfortunately this new species has not been published. According to the Zoological Code of Nomenclature it must be regarded as a nomen nudum. In his dissertation, Van Grootel gave an excellent description and provided a complete set of measurements of his new species. However, no SEM illustrations were provided and the reflected light microscope images (Van Grootel, 199; pl. 8, figs. 11-15) do not fully show the ornamentation. Consequently, for the stability of nomenclature it is preferred to designate another holotype from the present Saudi Arabian material and to leave "Spinachitina spinosa" as a nomen nudum. The specimens recorded by Van Grootel (1990) show the same important variations of the vesicle length (L) ranging from 140 to $333 \mu \mathrm{m}$ (mean: $226 \mu \mathrm{m}$ ) for the Belgian population (see Table 5, for comparison). Because the occurrence of a spiny ornamentation on its flanks, Spinachitina geerti sp. nov. clearly differentiates from the other early Silurian Spinachitina species, especially from $S$. fragilis (Nestor, 1980a), which has a similar silhouette (e.g., see Bourahrouh, 2002; Butcher, 2009). S. maennili (Nestor, 1980b) has a sub-cylindrical vesicle and no ornamentation on the chamber. A few Late Ordovician species have spiny walls such as S. cervicornis (Eisenack, 1931) and S. taugourdeaui (Eisenack, 1968). These two species, however, have more strongly developed processes on their margin. S. imperita (Dicevitchius, 1971) has a different silhouette as its cylindrical neck is longer than the chamber. Moreover, its wall seems 
glabrous.

During previous investigation on the subsurface chitinozoans from Saudi Arabia, rare Spinachitina specimens with a spiny ornamentation on the chamber have been recorded in cores 18 to 20 of the UDYN-1 well. Some of the recovered specimens with subcylindrical vesicles were tentatively referred to $S$. sp. aff. maennili by Paris (1991). Other ones with less obvious spines on the chamber were assigned to S. maennili (Nestor, 1980b). Owing to the variations recorded in the present population of $S$. geerti $\mathrm{sp}$. nov., the UDYN-1 specimens are included in the synonymy list of the new species. Other Spinachitina specimens recorded in well "QA" (Al-Hajri, 1991, pl. 25, figs. 1-4; see synonymy above) could also belong to $S$. geerti sp. nov. because the tiny granules occurring on their transparent neck may represent spine remains.

Range and geographic distribution: In the Baq'a-4 core hole, S. geerti sp. nov. has been recorded exclusively in cores $28(240.7 \mathrm{ft})$ where it is abundant, and in core $19(163.0 \mathrm{ft})$ (very rare; see Fig. 7). The corresponding strata belong to the upper part of the hemeri Biozone, which is assigned to the Aeronian, most likely to the mid-late Aeronian (see discussion above). Van Grootel (1990) recorded his "Spinachitina spinosa" nomen nudum in samples from the subsurface of the Brabant Massif (Belgium) in the Kortrijk 83W-421 (208.3 and 232.1 m), Kortrijk 83W-44 (168.0 to $215.5 \mathrm{~m}$ ) and Steenkerke 50E-134 (267.0 and 323.0 m) core holes. According to Van Grootel (1990, p. 80) the corresponding strata range from the Aeronian to the Telychian (middle part of the sedgwickii to the crispus graptolite zones). In Saudi Arabia, if one accepts the synonymy proposed here, S. geerti sp. nov. ranges through the Aeronian as documented in the UDYN-1 and Baq'a-4 wells. However, its relative abundance is very low in the early Aeronian. A specimen recorded in core $19(160.3 \mathrm{ft})$ in the Baq'a-4 well displays a crown of numerous (ca. 50) short blunt spines on the margin and bears tubercles on its flanks (Plate VIII, 2). It is provisionally referred to $S$. geerti sp. nov. as 
it may correspond to a corroded specimen. If the suggested synonymy of the specimens recorded by Al-Hajri (1991) in the "QA" well is confirmed by SEM observations, the species is also present in the Qusaiba Member in the subsurface of the Tabuk area (northern Saudi Arabia).

Family Lagenochitinidae Eisenack, 1931, emend Paris, 1981

Subfamily Cyathochitininae Paris, 1981

Genus Cyathochitina Eisenack, 1955b, emend Paris et al., 1999

Type species: Conochitina campanulaeformis Eisenack, 1931

Cyathochitina neolatipatagium sp. nov. Paris (Plate VI, 7-8, 11)

1988 - Cyathochitina campanulaeformis (Eisenack, 1931); McClure, pl. VII, fig. 16.

1991 - Cyathochitina latipatagium Jenkins, 1970; Al-Hajri, pl. 28, fig. 8; pl. 29, fig. 1.

1991 - Cyathochitina kuckersiana (Eisenack, 1934); Al-Hajri, pl. 37, figs. 3 and 6.

1994 - Cyathochitina kuckersiana (Eisenack, 1934); Nestor, pl. XXIII, figs. 7-8

v. 2003 - Cyathochitina neolatipatagium nomen nudum; Paris, pl. 6, figs. 7-8, 11.

Derivation of the name: the name indicates that this new species is similar to $C$. latipatagium, which is a Late Ordovician species.

Holotype: Plate VI, 8, core 14, 136.5 ft, IGR 72293, (Q40/4). 
Type locality: Qusaiba-1 core hole, core 14, North Central Saudi Arabia.

Type stratum: Qusaiba Member of the Qalibah Formation, core 14, $135.5 \mathrm{ft}$, mid-Aeronian (hemeri Biozone).

Paratypes: Plate VI, 7, core 14, at 133.45 ft, IGR 72298, (Q50); Plate VI, 11, core 14, at $136.5 \mathrm{ft}$, IGR 72293, (Q40).

Material: 1585 specimens picked from the organic residues of core 14 (4 samples, see Fig. 6) from the Qusaiba-1 core hole. Some of the sorted specimens were used for $\delta^{13} \mathrm{C}$ chit. analyses and for chemical organic analyses of the chitinozoan wall (Jacob et al., 2007); 114 specimens picked in cores 25 and 22 from the Baq'a-3 core hole (Fig. 8; Table 21).

Diagnosis: Large Cyathochitina species with a short cylindrical neck, a thickset conical chamber, and a very wide and rather thick carina extending perpendicularly from a thickwalled margin; the glabrous chamber has a corrugate surface; concentric rim pattern occurs on the carina.

Description: This Cyathochitina species is quite large with the diameter of the chamber (excluding the carina) ranging from 117 to ca. $240 \mu \mathrm{m}$ (mean diameter: $168 \mu \mathrm{m}$ ) (see Table 6; Fig. 12). The holotype is partially compressed along its longitudinal axis. Consequently, the actual lengths of the vesicle and neck are likely higher than the measures reported on Table 6 . This vertical compression is due to its wide diameter (maximum diameter of the vesicle, including the carina $=227 \mu \mathrm{m}$ ) exceeding the vesicle length and to the thickened margin that prevent the lateral flattening (the vesicle settles on its bottom, instead of on its flanks as is the rule for elongated vesicles). Such oriented deformation is frequently observed in the examined populations (Plate VI, 7-8). The neck is cylindrical and its length does not exceed the length of the thickset chamber. The flanks are normally straight (no shoulder) and taper rapidly toward the conspicuous flexure. The widened lower part of the chamber of the paratype (Plate VI, 7) is due to the differential compression of the flanks and of the occurrence of a thickened 
margin. The vesicle surface is glabrous, but variably developed corrugations are visible on the chamber wall. This pattern results from cross distribution of low longitudinal and horizontal elevations (or of discrete thickenings of the wall). The carina is well-developed (mean width: $22.7 \mu \mathrm{m}$; see Table 6) and displays concentric thickened rims or ridges (visible mainly in transmitted light microscope). This double-walled carina, with a rounded border (Plate VI, 7) is oriented perpendicular to the margin. Its width is variable (ranging from 10 to $44 \mu \mathrm{m}$ ) and seems generally correlated with the chamber diameter (Fig. 12). The lateral compression of the vesicle (flattening perpendicularly to the vesicle axis) generates radial folds of this carina (see left side of the carina on Plate VI, 7).

Measurements (Table 6; Fig. 12).

\begin{tabular}{|l|l|l|l|l|l|}
\hline & L & lc & Dp & Dc & l. carina \\
\hline Holotype & 175 & 87 & 160.1 & 50 & 31 \\
\hline Mean & 199.6 & 94.3 & 167.6 & 61.8 & 22.7 \\
\hline Maximum & 284.8 & 154.1 & 237.9 & 83.8 & 43.6 \\
\hline Minimum & 134 & 40.2 & 117.3 & 39.6 & 10.1 \\
\hline
\end{tabular}

Table 6: Biometric data (micrometers) for Cyathochitina neolatipatagium sp. nov. Means are based on 40 specimens from the Qusaiba-1 core hole, core 14 at 136.5 and $133.35 \mathrm{ft}$ depth (no correction factor for compression used as most vesicles are three-dimensional; see Pl. 6).

Discussion: C. neolatipatagium sp. nov. is distinguished from most the other Cyathochitina species, except from C. latipatagium Jenkins, 1969, which also has a very wide carina. The carina of the latter, however, is thinner than the carina of $C$. neolatipatagium, which chamber has a thickened margin. The widest part of this chamber is located just above the carina. The two species are very similar, but it is unlikely that $C$. latipatagium specimens can have a 
"Lazarus" distribution with more than 5 million years between their ranges. For that reason and based on the slight differences listed above this new species is proposed. McClure (1988, pl. VII, fig. 16) and Al-Hajri (1991) illustrated Cyathochitina specimens with a large carina from the Qusaiba Member of the Qalibah Formation from the subsurface of the Tabuk and Qasim areas that most likely belong also to $C$. neolatipatagium sp. nov. (see synonymy list). Nestor (1994) illustrated individuals identified as Cyathochitia kuckersiana (Eisenack 1934) from the Varkla core in Estonia. One of the specimens recorded by this author (pl. XXIII, fig. 8) in strata from the Raikülla regional stage (Aeronian) shows the circular rims and the rounded edge of $C$. neolatipatagium sp. nov. In our opinion, this justifies the synonymy proposed here, even if Nestor (1994, p. 80) considers the Late Ordovician and the early Silurian Cyathochitina with a morphology recalling C. kuckersiana as probable intraspecific variations of this species.

Range and geographic distribution: The new species is extremely abundant (up to $70 \%$ of the recorded specimens; see Fig. 6; Table 19) in the upper part (cores 14 to 16) of the Qusaiba-1 core hole. The corresponding strata represent part of the Qusaiba Member of the Qalibah Formation, assigned to the mid-Aeronian based on an independent graptolite control (Zalasiewicz et al., 2007). C. neolatipatagium sp. nov. occurs also in the Baq'a-3 core hole where it is the dominant species in core 22 at $206.9 \mathrm{ft}$ (39\% of the identified chitinozoans; Fig. 8). In core 25 , at $229.7 \mathrm{ft}$, it represents only $1 \%$, but in a much more abundant assemblage. In the Baq'a-3 well the corresponding samples are still from the Qusaiba Member, but they are referred to the upper part of the obtusa Biozone, which is tentatively assigned to the mid-Telychian (see discussion above, and Fig. 9). The distribution of $C$. neolatipatagium sp. nov. in the Qusaiba Member is striking. It seems to be controlled by sporadic "blooms", by environmental changes (e.g., more silty facies; see Table 1 and 3) or by variations in their predation. C. neolatipatagium sp. nov. is only reported from Saudi Arabia. 
If one accepts the proposed synonymy, this new species occurs also in the Qusaiba Member of the Qalibah Formation of the Qasim and Tabuk areas in Saudi Arabia, and in the Aeronian of Estonia (Varkla core; see Nestor, 1994).

Subfamily Ancyrochitininae Paris, 1981

Genus Ancyrochitina Eisenack, 1955a

Type species: Conochitina ancyrea Eisenack, 1931

Ancyrochitina alhajrii sp. nov. Paris (Plate X, 2, 4; Plate XI, 6)

v. 2005- Ancyrochitina alhajrii nomen nudum; Paris, pl. 4, figs. 2a-b, 4a-b.

Derivation of the name: this new species is dedicated to Sa'id Al-Hajri (Saudi Aramco) for our fruitful and long-term scientific collaboration.

Holotype: Plate X, 4; core 47, at 431.7 ft, IGR 72339 (O40).

Type locality: Baq'a-3 core hole, North Central Saudi Arabia.

Type stratum: Qusaiba Member of the Qalibah Formation; core 47, sample from $431.7 \mathrm{ft}$, early Telychian

Paratype: Plate X, 2; core 47, at 431.7 ft, IGR 72339 (O45).

Material: 239 specimens picked in the organic residues from cores 47 to 42 (Fig. 8) of the Baq'a-3 core hole.

Diagnosis: Ancyrochitina species with a well-developed cylindrical neck, a flaring collarette 
and a thickset conical chamber with a flat to slightly convex bottom; four to six long hollow processes pointing down from the margin; densely distributed minute hairs-like spines on the flanks and base of the neck.

Description: This medium-sized new Ancyrochitina species (mean vesicle length ca. $127 \mu \mathrm{m}$; see Table 7; Figs. 13a-b) shares all the characteristics of the genus as defined by Eisenack (1955a). The well-developed cylindrical neck terminates in a slightly flaring membranous collarette. A straight lip surrounds the aperture (Plate X, 4a). The length of the neck and collarette exceeds that of the chamber (mean: lc/lp $>1$ ). A conspicuous flexure separates the neck from the chamber. No shoulder is observed on this thickset conical chamber, which diameter is larger than its length (i.e., Dp/lp $>1$ ). The bottom of the chamber is flat or slightly convex. This convexity is frequently accentuated during the compression of the vesicle, which causes the folding of the bottom wall inside of the chamber (Plate X, 4a). The margin is fairly sharp and bears four to six long and wide hollow processes (process length up to ca. $84 \mu \mathrm{m}$; diameter ca. $10 \mu \mathrm{m})$. These processes taper progressively toward their rounded distal end and are oriented more or less parallel to the longitudinal axis of the vesicle. The most discriminating character is the occurrence of randomly distributed thin hairs all over the vesicle. These slender hairs (diameter less than $0.5 \mu \mathrm{m}$; length ranging from 5 to $10 \mu \mathrm{m}$; see Plate X, 2b, 4b) are smaller towards the aperture. The granules stuck on the wall of some specimens (Plate X, 4b) are "exotic" (not part of the ornamentation of the vesicle). Measurements (Table 7; Figs. 13a-b).

\begin{tabular}{|l|l|l|l|l|l|l|}
\hline & L & Lc & Dp & Dc & Dcoll. & l. processes \\
\hline Holotype & 117.3 & 63.7 & $\begin{array}{l}(82.1) \\
* 65.7\end{array}$ & $\begin{array}{l}(30.2) \\
* * 21.2\end{array}$ & $\begin{array}{l}(40.2) \\
* * 28.2\end{array}$ & 46.9 \\
\hline Mean & 126.7 & 63.1 & $(79.5)$ & $(33.1)$ & $(42.3)$ & 50.8 \\
& & & $* 63.6$ & $* * 23.2$ & $* * 29.6$ & \\
\hline
\end{tabular}




\begin{tabular}{|l|l|l|l|l|l|l|}
\hline Maximum & 160.8 & 93.8 & $\begin{array}{l}(93.8) \\
* 75.1\end{array}$ & $\begin{array}{l}(41.9) \\
* * 29.4\end{array}$ & $\begin{array}{l}(50.3) \\
* * 35.2\end{array}$ & 83.8 \\
\hline Minimum & 100.5 & 46,9 & $(67.0)$ & $(38.5)$ & $(33.5)$ & 23.5 \\
& & & $* 53.6$ & $* * 27.0$ & $* * 23.5$ & \\
\hline
\end{tabular}

Table 7: Biometric data (micrometers) for Ancyrochitina alhajrii sp. nov. Means are based on 37 compressed specimens from the Ba'qa-3 core hole, core 47 at $431.7 \mathrm{ft}$ depth (raw data: between brackets; $*$ correction factor: $0.8 ; * *$ correction factor: 0.7$)$.

Discussion: Many Ancyrochitina species have a silhouette, or processes similar to those of $A$. alhajrii sp. nov. The latter, however, is easily distinguished by its distinct hair-like vesicle ornamentation. The specimen (Plate XI, 6), from the Baq'a-3 well (core 47 at $431.7 \mathrm{ft}$ ) does not clearly show the hair-like ornamentation of the chamber because organic matter coats the wall. The apparent branching of one process of this specimen is interpreted as an artifact (organic fragment stuck on the process). In some cases the hollow processes of A. alhajrii show a more or less cellular pattern like the processes of Plectochitina pseudoagglutinans. The latter, however, lacks the hairy ornamentation on its chamber.

Range and geographic distribution: A. alhajrii sp. nov. is only recorded in the Baq'a-3 core hole, in cores 47 to 42 (431.7 to $388 \mathrm{ft}$; Fig. 8; Table 21). It is the dominant species in three samples (e.g. $42 \%$ at $408.7 \mathrm{ft}$; see Fig. 8; Table 21) belonging to the Qusaiba Member of the Qalibah Formation. The corresponding interval corresponds to the lower part of the macclurei Biozone (merrelli and crassicarinata subbiozones pro-parte) and is assigned to the early Telychian (Figs. 8-9), based on graptolite evidence (turriculatus Biozone). 
v. 2005- Angochitina camilleae nomen nudum; Paris, pl. 2, figs. 1 and 6.

Derivation of the name: this species is dedicated to my granddaughter Camille Paris Holotype: Plate VIII, 1, core 19, at 163.0 ft, IGR 72364 (P41/4).

Type locality: Baq'a-4 core hole, North Central Saudi Arabia.

Type stratum: Qusaiba Member of the Qalibah Formation; core 19, sample from $163.0 \mathrm{ft}$, Aeronian.

Paratype: Plate VIII, 6, core 19, at 163.0 ft, IGR 72364 (P44).

Material: 35 specimens have been picked from the organic residues of cores 19 to 23 (Fig. 7;

Table 20) from the Baq'a-4 core hole (about 350 specimens in the organic residue, as only $10 \%$ was picked; Table 2).

Diagnosis: Ancyrochitina species with a thickset conical chamber; fairly short neck terminated by a flaring collarette with serrate lips; smooth vesicle walls; six very long tapering processes briefly branched distally.

Description: This small sized species (mean vesicle length ca. $110 \mu \mathrm{m}$; Table 8; Figs. 14a-b) displays all the generic characters listed by Eisenack (1955a) for Ancyrochitina. The conical chamber has straight (Plate VIII, 1) or slightly convex flanks (no shoulder) tapering toward a conspicuous flexure (the convexity of the flanks may be accentuated during the compression of the vesicle). The diameter and the length of the chamber are in the same range of values, ca. 80 to $90 \mu \mathrm{m}$. The short cylindrical part of the neck is prolonged with a well-developed collarette (collarette length close to the half of the length of the neck). The prosome is usually implanted in the base of the neck, which is therefore not fully compressed (correction factor of 0.9). Short spines (Plate VIII, 1) or minute serrations (Plate VIII, 6) border the lips surrounding the aperture. The vesicle wall is usually smooth; the granules on the holotype 
(Plate VIII, 1) result from amorphous organic matter adhering to the wall. The structure of the six long processes originating on the margin, sub-perpendicular to the vesicle axis, constitutes the most distinct character of this new species. These extremely long hollow processes (mean total length of the processes, including their branches $=55 \mu \mathrm{m}$, but reaching $87 \mu \mathrm{m}$ for some specimens) taper very gently distally from a short conical base. The first branching occurs at about the last fourth of the total length. The resulting short branches are thinner and may subdivide up to four times. These successive short branches simulate a sort of distal fleuron; Plate VIII, 1, 6).

Measurements (Table 8; Figs. 14a-b).

\begin{tabular}{|l|l|l|l|l|l|l|}
\hline & L & lc & Dp & dc & dcoll. & l. proc. \\
\hline Holotype & 103.9 & 46.9 & $(80.4)$ & $(31.8)$ & $(43.6)$ & 74 \\
& & & $* 64.3$ & $* * * 28.6$ & $* * 30.5$ & \\
\hline Mean & 109.4 & 51.0 & $(81.0)$ & $(30.0)$ & $(39.6)$ & 55 \\
& & & $* 64.8$ & $* * * 27.0$ & $* * 27.8$ & \\
\hline Maximum & 140.7 & 70.4 & $(93.8)$ & $(36.9)$ & $(55.3)$ & 87.1 \\
& & & $* 75.0$ & $* * * 33.2$ & $* * 38.7$ & \\
\hline Minimum & 93.8 & 36.9 & $(63.7)$ & $(23.5)$ & $(30.2)$ & 33.5 \\
& & & $* 51.0$ & $* * * 21.2$ & $* * 21.2$ & \\
\hline
\end{tabular}

Table 8: Biometric data (micrometers) for Ancyrochitina camilleae sp. nov. Means are based on 30 compressed specimens from the Ba'qa-4 core hole, core 19 at $163.0 \mathrm{ft}$ depth (raw data: between brackets; $*$ correction factor: $0.8 ; * *$ correction factor: $0.7 ; * * *$ correction factor: 0.9 .

Discussion: This new species is reminiscent of several other Late Ordovician or early Silurian Ancyrochitina with very long processes and without spines on the neck or on the chamber. Among the closest species, A. ramosaspina Nestor, 1994 is larger and the branching of its 
processes occurs at about one half of their total length; each resulting branch is more robust. Fairly similar chitinozoans (but with a different branching pattern) tentatively identified as $A$. cf. ramosaspina occur in the lower Llandovery of the Murzuk Basin, Libya (Paris et al., 2012, pl. 4, figs. 2, 5-6). A. porrectaspina Nestor, 1994 has shorter processes with a different branching pattern (less numerous). A. longispina Achab, 1978 has a quite close silhouette. However, its neck is better developed and the pattern of the branching of its long processes is also different (first branches perpendicular to the main trunk and occurring more proximally than in A. camilleae sp. nov.). Quite similar specimens previously identified as A. cf. longispina have been recorded in the basal Silurian of the Kufra Basin, Libya (Paris, unpublished).

Range and geographic distribution: A. camilleae sp. nov. is only recorded in the Baq'a-4 well, in cores 19 to 23 from the Qusaiba Member of the Qalibah Formation. The corresponding strata are assigned to the Aeronian, and most likely to the late Aeronian as early Telychian graptolites of the guerichi Biozone occur quite close above these strata (Zalasiewicz et al., 2007). A camilleae is the index species of the chitinozoan subbiozone defined herein, in the upper part of the hemeri Biozone (Fig. 9).

Genus Plectochitina Cramer, 1964

Type species: Plectochitina carminae Cramer, 1964.

Plectochitina alisawyiahensis sp. nov. Paris (Plate IX, 4, 6-7; Plate XI, 4; Plate XII, 7; Plate $\mathrm{XV}, 4-6,8-9)$ 
1988 - Clathrochitina sylvanica Jenkins, 1970; McClure, pl. XI, figs. 4-6, 8-9 (non fig. 10)

1988 - Plectochitina carminae Cramer, 1964; McClure, pl. XI, fig. 12.

? 1991 - Plectochitina pseudoagglutinans Taugourdeau, 1963; Al-Hajri, pl. 34, fig. 6 (non figs. 2-5).

v. 1993 - Plectochitina combazii Cramer, 1967; Paris, pl. 1, figs. 7-8.

v. 2005 - Plectochitina alisawyiahensis nomen nudum; Paris, pl. 3, figs. 4,6; pl. 5, fig. 4; pl. 6, fig. 7; pl. 9, figs. 4-5, 8 .

Derivation of the name: The species name refers to the locality Al Isawyiah, in Saudi Arabia. The ISWH EW-9 well drilled in this locality yielded the first specimens of the new species described here.

Holotype: Plate XII, 7, core 40, sample from 370.4 ft, IGR 72332 (P44/3).

Type locality: Baq'a-3 core hole, North Central Saudi Arabia.

Type stratum: Qusaiba Member of the Qalibah Formation; core 40, sample from $370.4 \mathrm{ft}$, early Telychian.

Paratypes: Plate XV, 4, core 30, sample from 271.8 ft. IGR 72319 (Q45/3); Plate XV, 5, core 30, sample from $271.8 \mathrm{ft}$. IGR 72319 (R45); Plate XV, 8, core 30, sample from $271.8 \mathrm{ft}$, IGR 72319 (R45/1); Plate XV, 9, core 27, sample from 250.5 ft, IGR 72316 (R41/1).

Material: 304 specimens have been picked from the organic residues from Baq'a-3, cores 16 to 56 (Fig. 8; Table 21) and 112 specimens from the organic residues from Baq'a-4, cores 7 to 17 (Fig. 7; Table 20). Several hundred additional specimens were available in the unpicked organic residues (see Tables 2-3) and in the ISWH EW-9 material (see below).

Diagnosis: Plectochitina species with flat-based conical chamber and short cylindrical neck flaring around the aperture; fairly sharp margin carrying a crown of long and wide cell-like processes; these simple or anastomosed processes are connected at their distal end, either as 
several separated sets, or all together.

Description: This spectacular and rather polymorphic species (Table 9; Figs. 15a-b; Plate XV, 4-6, 8-9) shows all the generic characters of Plectochitina as defined by Cramer (1964), i.e. a differentiated chamber/neck and cell-like processes. The vesicle is relatively small (average vesicle length: ca. $110 \mu \mathrm{m}$ ) with regard to the processes (lproc.: up to $130 \mu \mathrm{m}$ length) (see Table 9 and Fig. 15b). The conical chamber has a flat base and a sharp margin. The straight flank (no shoulder) passes to a short flaring neck through a weakly individualized flexure. This neck, including the collarette, represents close to the half of the vesicle length (processes not included) (Plate XV, 4-5, 9). A membranous flared lip surrounds the straight aperture. The vesicle walls are usually entirely smooth. A specimen with a few random spines on the flexure has been observed (Plate IX, 7). The discriminating character is the very large crown of cell-like (vesicular) processes that runs around the margin. These numerous processes (about 15) are frequently much longer than the chamber. The diameter of these processes is quite variable, ranging from very wide, cylindrical or gently tapering isolated processes (e.g. Plate XV, 5) to slender elements anastomosing distally (Plate XV, 8). The end of the processes are connected, either by a hollow rim (Plate $\mathrm{XV}, 5$ ) or more frequently arranged into three or four "buckle-like" structures around the margin (Plate XV, 4, 8-9). The processes originate directly from the margin wall, or from a membranous carina -like expansion (Plate XV, 6)

Measurements (Table 9; Figs. 15a-b).

\begin{tabular}{|c|c|c|c|c|c|c|}
\hline & $\mathrm{L}$ & lc & $\mathrm{Dp}$ & lc & lcoll. & lproc. \\
\hline Holotype & 127.3 & 60.3 & $\begin{array}{l}(77.1) \\
* 61.70\end{array}$ & $\begin{array}{l}(33.5) \\
* * 23.5\end{array}$ & $\begin{array}{l}(35.2) \\
* * 24.6\end{array}$ & 83.8 \\
\hline Mean & 109,6 & 49,6 & $\begin{array}{l}(78,1) \\
* 62.5\end{array}$ & $\begin{array}{l}(32.5) \\
* * 22.8\end{array}$ & $\begin{array}{l}(36.0) \\
* * 25.2\end{array}$ & 67.4 \\
\hline
\end{tabular}




\begin{tabular}{|l|l|l|l|l|l|l|}
\hline Maximum & 140.7 & 83.8 & $\begin{array}{l}(100.5) \\
* 80.4\end{array}$ & $\begin{array}{l}(50.2) \\
* * 35.2\end{array}$ & $\begin{array}{l}(43.6) \\
* * 30.5\end{array}$ & 130.7 \\
\hline Minimum & 83.8 & 30.2 & $(63.7)$ & $(23.5)$ & $(23.5)$ & 33.5 \\
& & & $* 51$ & $* * 16.5$ & $* * 16.5$ & \\
\hline
\end{tabular}

Table 9: Biometric data (micrometers) for Plectochitina alisawyiahensis sp. nov. Means are based on 30 compressed specimens from the Ba'qa-3 core hole, core 40 at $370.4 \mathrm{ft}$ depth, and core 49 at $450.1 \mathrm{ft}$ depth (raw data: between brackets; *correction factor: 0.8 ; ** correction factor: 0.7).

Discussion: The specimens identified as Clathrochitina sylvanica by McClure (1988; pl. XI, figs. 4-6, 8-9,11) from the subsurface of Tabuk and Qasim areas show the same variable pattern of arrangement of their cell-like processes as $P$. alisawyiahensis sp. nov., from the Baq'a-4 and Baq'a-3 core holes. With the exception of the specimen (pl. XI, fig. 10), which is referred to $P$. clathrospinosa, all McClure's (1988) specimens are therefore included in the synonymy list of $P$. alisawyiahensis sp. nov.

Several other Plectochitina species have been described in the Silurian of northern Gondwana regions. P. saharica (Taugourdeau, 1962) from the early Silurian of SE Algerian Sahara is probably the most similar species. Its processes appear less well-developed and the available illustration does not allow a detailed comparison. P. fenesdiculae Al-Ameri, 1989, and $P$. lubnia (Al-Ameri, 1989), from the subsurface of Tripolitania (Libya) have longer necks and a different arrangement of their processes. P. combazii Cramer, 1967 described in the Llandovery of Spain has numerous very thin processes. The provided illustration, however, does not demonstrate the presence of an external rim joining the distal end of the processes. $P$. irregularis Cramer and Diez, 1978 described from the Lochkovian of Spain has very thin anastomosing processes and a better-developed neck. $P$. carminae is quite close to $P$. 
alisawyiahensis sp. nov., but it displays a different arrangement of its cell-like processes (fewer and thinner proximal branches; higher number of anastomosing knots). $P$. sansalvadorensis (Schweineberg, 1987) from the Gorstian of Spain has processes with a similar anastomosing pattern, but its neck is much more developed than that in $P$. alisawyiahensis sp. nov.

Some Late Ordovician species have morphologies similar to $P$. alisawyiahensis sp. nov. The processes of P. concinna (Achab, 1978) from the Late Ordovician of eastern Canada has quite a similar anastomosing pattern but the resulting "buckle-like" sets of processes are much shorter than those of P. alisawyiahensis sp. nov. P. sylvanica (Jenkins, 1970) from the late Katian of Oklahoma has thinner processes with a different anastomosing pattern.

Range and geographic distribution: P. alisawyiahensis sp. nov. is extremely well-represented in the upper part of the Qusaiba Member of the Qalibah Formation in Saudi Arabia. It is quite abundant in the upper part of the Baq'a-4 well (Fig. 7; Table 20), where it occurs with A. macclurei, and with graptolites of the guerichi Biozone (Fig. 9). P. alisawyiahensis sp. nov. occurs irregularly along the investigated ca. $367.9 \mathrm{ft}$ (113.2 m) thick sequence in the Baq'a-3 well (from core 56 to core 16 inclusive). It is a rather long ranging species, which is recorded in the macclurei through silurica chitinozoan biozones (Fig. 8; Table 21) of Telychian age (Figs. 8-9). This new species has been reported under various names (see synonymy list) in other wells in Saudi Arabia (McClure, 1988; Al-Hajri, 1991). The most productive samples were from ISWH EW-9 well, where the species is the dominant chitinozoan species in cutting samples from $3478 \mathrm{ft}(1058 \mathrm{~m})$ to $3603 \mathrm{ft}(1096 \mathrm{~m})$, and in a core sample from $3694.7 \mathrm{ft}$ (1093.5 m). It is less abundant in the other investigated core samples at $1095.5 \mathrm{~m}$ to $1098 \mathrm{~m}$ (Paris, 1993). This species and the associated chitinozoans allow now to firmly assign this part of the ISWH EW-9 well to the Telychian. 
Plectochitina alnaimi sp. nov. Paris (Plate III, 6; Plate IV, 9; Plate V, 2, 10)

1991 - Plectochitina sp. 1; Al-Hajri, pl. 30, fig. 5.

2005 - Ancyrochitina nov. sp. A; Paris, pl. 3, fig. 9; pl. 2, figs. 3 and 10.

Derivation of the name: This new species is dedicated to Abdulla Al-Naim, the Vice President for Exploration in Saudi Aramco who has been an active supporter of the CIMP/Saudi Aramco project from its inception.

Holotype: Plate V, 2, core 14, sample from 140.10 ft; IGR 72291 (Q42).

Type locality: Qusaiba-1 core hole, North Central Saudi Arabia.

Type stratum: Qusaiba Member of the Qalibah Formation; core 14, sample from $140.1 \mathrm{ft}$, Aeronian.

Paratype: Plate V, 10, core 16, sample from 150.8 ft, IGR 72286 (R44).

Material: 2178 specimens picked from cores 27 to 32 (136.5 to $217.2 \mathrm{ft}$ depth) from the Qusaiba-1 core hole (Fig. 6) and several thousand additional specimens in the corresponding unpicked residue (Table 1).

Diagnosis: Small Plectochitina species with a conical chamber and a short cylindrical neck (L/lc close to 2) ended by a flaring collarette; granules or blunt cones cover the vesicle wall; up to eight bi- or more rarely multi-rooted processes with a spongy to cell-like (vesicular) internal structure.

Description: This chitinozoan is quite small: its vesicle length (L) ranges from ca. 74 to 134 $\mu \mathrm{m}$, with an average length of ca. $110 \mu \mathrm{m}$. The holotype $(\mathrm{L}=103.9 \mu \mathrm{m})$ is shorter because the lips are partly folded within the aperture (Plate V, 2). The straight flanks (no shoulder observed) taper rapidly toward a conspicuous flexure. This gives a thickset aspect to the 
chamber, where the width is usually greater than its length (mean Dp/lp close to 1.35), even after correction for compression (see Table 10). Randomly distributed granules or fairly large blunt cones occur on the vesicle wall, including the chamber bottom (Plate V, 10). These granules fade away on the neck. Minute interrupted ridges present between the granules make a sort of irregular array with a more or less horizontal pattern (only visible by SEM). The subcylindrical neck ends with a membranous collarette flaring toward the aperture (straight to finely serrate lips). The chamber bottom is flat to slightly convex but depending on the compression pattern, its wall may be folded within the chamber (Plate V, 10) or it can be totally tilted (Plate V, 2). Six to eight processes of variable length and with a "spongy" to celllike (vesicular) internal structure (visible in transmitted light) are located on the margin. They are bi-rooted (Plate V, 2), occasionally multi-rooted and rarely simple with a widened base. These processes are very brittle and only the proximal part may be preserved. For that reason the average length (ca. $20 \mu \mathrm{m}$ ) of the processes given on Table 10 is largely under-estimated. When fully preserved the tapering distal part of the processes represents at least two third of their total length (Plate V,2).

Measurements (Table 10; Figs. 16a-b).

\begin{tabular}{|l|l|l|l|l|l|l|}
\hline & L & lc & Dp & dc & dcoll. & lproc. \\
\hline Holotype & 103.9 & 53.7 & $\begin{array}{l}(70.1) \\
* 56.1\end{array}$ & $\begin{array}{l}(26.8) \\
* 21.5\end{array}$ & $\begin{array}{l}(40.2) \\
* * 28.2\end{array}$ & 33.5 \\
\hline Mean & 110.1 & 56.1 & $(72.5)$ & $(30.5)$ & $(39.3)$ & 19.5 \\
& & & $* 58$ & $* 24.5$ & $* * 27.5$ & \\
\hline Maximum & 134.0 & 73.7 & $(102.2)$ & $(36.9)$ & $(42.3)$ & 49.9 \\
& & & $* 81.8$ & $* 29.5$ & $* * 29.7$ & \\
\hline Minimum & 73.7 & 30.2 & $(60.3)$ & $(20.1)$ & $(26.8)$ & $>3.5$ \\
& & & $* 48.3$ & $* 16.1$ & $* * 18.8$ & \\
\hline
\end{tabular}


Table 10: Biometric data (micrometers) for Plectochitina alnaimi sp. nov. Means are based on 55 compressed specimens from the Qusaiba-1 core hole, core 14 at $140.1 \mathrm{ft}$ depth (raw data: between brackets; *correction factor: $0.8 ; * *$ correction factor: 0.7$)$.

Discussion: When collecting the biometric data with a transmitted light microscope at high magnification, the processes of this chitinozoan show constant spongy internal structure. Cramer (1964) and Paris et al. (1999) regarded this character as diagnostic for Plectochitina. The former generic assignment of this new species to Ancyrochitina, based exclusively on SEM, is therefore modified here (see synonymy). Al-Hajri (1991, pl. 30, fig. 5) illustrated a chitinozoan sp. nov. with a silhouette, multi-based processes and dimensions fitting with the present definition $P$. alnaimi sp. nov. (see synonymy).

Plectochitina alnaimi sp. nov. belongs to the Plectochitina forms with bi- or multi-rooted relatively short processes. Such taxa are quite common in the early Silurian and may be confused with Ancyrochitina species illustrated by SEM. A. diabolo Eisenack, 1937 from the Silurian of the Baltic area has a similar silhouette, but its robust processes are not described as bi-rooted or with a spongy internal structure. A. magna Nestor, 1982 from the Wenlock of Baltoscandia is much larger and has processes with a wider proximal part. A. obesa Tsegelnjuk, 1982 from the early Wenlock of Podolia has a similar silhouette, but not bi-rooted processes. A. spinosa Al-Ameri, 1989 has a conspicuous shoulder and no bi-rooted processes. A. alhajrii sp. nov. is differentiated from P. alnaimi sp. nov. by the lack of processes with a spongy to cell-like structure, and because of its hair-like ornamentation covering the vesicle walls.

Range and geographic distribution: Plectochitina alnaimi sp. nov. is extremely abundant in most of the samples from the Qusaiba-1 core hole (Fig. 6; Table 19). It is the dominating species of the hemeri Biozone (70\% of the chitinozoans recorded at $140.1 \mathrm{ft}$ in the type 
stratum). The species, which has apparently its LAD at $136.5 \mathrm{ft}$, is already present but less abundant in the upper part of the qusaibaensis Biozone penetrated by the Qusaiba-1 core hole (Fig. 6; Table 19). Surprisingly it is missing in the main part of the alargada Biozone (Fig. 6). In the Qusaiba-1 core hole, the coexistence of $P$. alnaimi sp. nov. with graptolites of the convolutus Biozone supports a mid-Aeronian age for the range of the species. If one accepts the proposed synonymy, the new species is also present in northern Saudi Arabia, in sample 10 from the "QA" well of the Tabuk area (Al-Hajri, 1991).

Plectochitina jacquelineae sp. nov. Paris (Plate XIV, 4, 6)

1988 - Ancyrochitina sp.; McClure, pl. X, fig. 3.

1988 - Ancyrochitina merga Jenkins, 1970; McClure, pl. X, fig. 8.

? 1988 - Ancyrochitina erichseni Sommer and Van Boekel, 1963; McClure, pl. X, fig. 7.

? 1988 - Clathrochitina clathrata Eisenack, 1959, 1963; McClure, pl. XI, fig. 1 (non. fig. 2). v. 1993 - Plectochitina jiangsuensis Geng et al., 1987; Paris, fig. 2.

Derivation of the name: The species is dedicated to my wife Jacqueline Paris for her patient support during my career.

Holotype: Plate XIV, 6, core 34, sample from 306.0 ft, IGR 72323 (P43).

Type locality: Baq'a-3 core hole, North Central Saudi Arabia.

Type stratum: Qusaiba Member of the Qalibah Formation; core 34, sample from $306.0 \mathrm{ft}$, early Telychian.

Paratype: Plate XIV, 4, core 34, sample from $306.0 \mathrm{ft}$, IGR 72323 (R43).

Material: 52 specimens were picked from the organic residue of core 34 of the Baq'a-3 core 
hole (Fig. 8; Table 21). More than one hundred additional specimens are available in the remaining organic residue (see Table 3) and in the material from the ISWH EW-9 well (see below).

Diagnosis: Plectochitina species with granulose flanks; conical chamber with a welldeveloped cylindrical neck flaring around the aperture; rounded margin with a crown of ca. 20 to 30 very short processes; these spongy processes are simple or have short branches at their distal end.

Description: This medium sized chitinozoan (L ranging from ca. 74 to $174 \mu \mathrm{m}$; mean length: $130 \mu \mathrm{m}$; holotype length: $144 \mu \mathrm{m}$; see Table 11) has a conical chamber with rapidly tapering flanks and a flat base. The vesicle wall is rugose to granular. No shoulder is present on the chamber but a conspicuous flexure separates the tapering straight flanks from a welldeveloped neck (mean value of the ratio lc/L close to 0.61; see Fig. 17). Straight or very finely serrate lips surround the aperture of this cylindrical to gently flaring neck (Plate XIV, 4a, 6a). Occasionally, a membranous expansion of the prosome (with septa) extends out of the aperture (Plate XIV, 6a). This prosome is located deeply within the neck (proximal part originating near the flexure). The rounded margin carries a crown of numerous (usually 20 to 30) short spongy processes (length ranging from 3.5 to $13.4 \mathrm{~mm}$; mean= $7.3 \mathrm{~mm}$ ). In a few cases, a very short membrane (less than $3 \mu \mathrm{m}$ ) joins the base of these processes, which may branch in a fleuron-like structure at their distal end (Plate XIV, 4b). In other cases the processes taper or have a blunt end (Plate XIV, 6b). In transmitted light microscope, the short processes display a spongy structure, which supports an assignment to Plectochitina, rather than to Ancyrochitina (see discussion below).

Measurements (Table 11; Figs. 17a-b).

\begin{tabular}{|l|l|l|l|l|l|l|}
\hline & L & Lc & Dp & Dc & Dcoll. & lproc. \\
\hline
\end{tabular}




\begin{tabular}{|c|c|c|c|c|c|c|}
\hline Holotype & 144.1 & 86.6 & $\begin{array}{l}(95.9) \\
* 76.7\end{array}$ & $\begin{array}{l}35.1) \\
* 28.1\end{array}$ & $\begin{array}{l}(48.4) \\
* * 33.9\end{array}$ & 10.1 \\
\hline Mean & 130.3 & 79.9 & $\begin{array}{l}(91.8) \\
* 73.4\end{array}$ & $\begin{array}{l}(35.8) \\
* * 25.1\end{array}$ & $\begin{array}{r}(43.2) \\
* * 30.3 \\
\end{array}$ & 7.3 \\
\hline Maximum & 174.2 & 107.2 & $\begin{array}{l}(108.9) \\
* 87.1\end{array}$ & $\begin{array}{l}(43.6) \\
* * 30.5\end{array}$ & $\begin{array}{l}(53.6) \\
* * 375\end{array}$ & 13.4 \\
\hline Minimum & 73.7 & 46.9 & $\begin{array}{l}(62.0) \\
* 49.6\end{array}$ & $\begin{array}{l}(30.2) \\
* * 21.2\end{array}$ & $\begin{array}{l}(26.8) \\
* * 18.8\end{array}$ & 3.5 \\
\hline
\end{tabular}

Table 11: Biometric data (micrometers) for Plectochitina jacquelineae sp. nov. Means are based on 40 compressed specimens from the Baq'a-3 core hole, core 34 at $306.0 \mathrm{ft}$ depth (raw data: between brackets; *correction factor: $0.8 ; * *$ correction factor: 0.7$)$.

Discussion: Because the occurrence of a membrane joining the base of the processes of some specimens this species could be assigned to Anthochitina. In the present material this character is very unusual and the most common feature is the existence of processes directly fixed to the margin, such as on the holotype (Plate XIV, 6b). A generic assignment to Ancyrochitina is also conceivable, but the spongy structure of the processes better supports the assignment to Plectochitina, even if the occurrence of very short and numerous processes is an uncommon feature for this genus. Al-Hajri (1991; pl. 30, fig. 4) illustrated a chitinozoan with a membranous expansion (ending with spines) around the margin. This form from the “QI” well (Qasim area) was assigned to Clathrochitina sp. by Al-Hajri (1991). It has not been included in the synonymy of $P$. jacquelineae sp. nov. in spite of its similar outline because of the occurrence of the spiny membrane also present in some Anthochitina species recorded in the Qusaiba-1 core hole (e.g., Anthochitina primula from core 15 at $145.9 \mathrm{ft}$; Plate V, 11-12). In the ISWH EW-9 well, chitinozoans with a crown of frequently bi-rooted and longer 
processes ( $P$. sp. aff. jiangsuensis in Paris, 1993, pl. 2, figs. 6-7) have been reported from strata assigned here to the crassicarinata subbiozone. They are slightly different from $P$. jacquelineae sp. nov. and are not included in the synonymy. They may represent ancestors of this new species and only the youngest specimens (cuttings from 1006 to $1070 \mathrm{~m}$ ) reported as P. jiangsuensis in Paris (1993, fig. 2) are included in the synonymy. The very peculiar silhouette related to the occurrence of a crown of numerous processes is only reported in Ancyrochitina erichseni Sommer and Van Boekel, 1963. In the Brazilian species, however, the processes are better developed and the ratio chamber length on the neck length is different. Plectochitina jiangsuensis described by Geng et al. (1987) from the Llandovery of China has a similar morphology but its processes are longer and joined at their distal end by a rim. Anthochitina primula Nestor, 1994 from the Llandovery of Estonia has a well-developed spiny neck and a membranous rim surrounding the margin.

Range and geographic distribution: P. jacquelineae sp. nov. is quite abundant in the upper part of the Qusaiba Member of the Qalibah Formation in Saudi Arabia. It is restricted to core 34, at $306.0 \mathrm{ft}$, from the Baq'a-3 core hole (Fig. 8; Table 21) where it occurs with graptolites of the turriculatus s.l. Biozone of early Telychian age (Fig. 9). The species was also recorded in the ISWH WE-9 well (cuttings from $1006 \mathrm{~m}$ to $1070 \mathrm{~m}$ ) under the name "Pl. jiangsuensis" but its FAD is difficult to locate precisely in this well because many specimens are likely caved. If one accepts the synonymy proposed here, $P$. jacquelineae sp. nov. is also present in the Qusaiba Member of the subsurface of the Tabuk and Qasim area (McClure, 1988).

Plectochitina lucasi sp. nov. Paris (Plate XV, 3, 7)

1993 - Ancyrochitina n. sp. B; Paris, pl. 2, figs. 1-2. 
Derivation of the name: This species is dedicated to my grandson Lucas Paris

Holotype: Plate XV, 7, core 30, sample from 271.8 ft, IGR 72319 (T43/4).

Type locality: Baq'a-3 core hole, North Central Saudi Arabia.

Type stratum: Qusaiba Member of the Qalibah Formation; core 30, sample from $271.8 \mathrm{ft}$,

Telychian.

Paratype: Plate XV, 3, core 30, sample from 271.8 ft, IGR 72319 (T43/1).

Material: 280 specimens were picked from the organic residues of the Baq'a-3, cores 27 to 32

(Fig. 8; Table 21); about 3500 specimens are present in the organic residues as only $10 \%$ was picked from the samples at $271.8 \mathrm{ft}$ and at $250.5 \mathrm{ft}$, and $2 \%$ at $289.1 \mathrm{ft}$ (see Table 3).

Diagnosis: Long Plectochitina species with a small flat-bottomed conical chamber; very long cylindrical neck ended by a flaring collarette; vesicle wall smooth; five to six "lyre-like" shaped processes, with multi-roots and a cell-like (vesicular) internal structure.

Description: This long chitinozoan (L ranging from 177.5 to $348 \mu \mathrm{m}$; mean length: $271.6 \mu \mathrm{m}$; holotype length: $254.6 \mu \mathrm{m}$ without processes). The straight to slightly convex flanks of the thickset chamber converge rapidly toward a conspicuous flexure (chamber diameter larger than the chamber length). The vesicle wall is smooth; the polygonal pattern visible around the margin of the holotype (Plate XV, 7b) is possibly a preservation artifact only visible with SEM at high magnification. No shoulder has been observed. The long and slender neck (mean length of the neck, including the collarette: ca. $197.5 \mu \mathrm{m})$ gives a distinctive silhouette to this species (ratio L/lc close to 1.4). The collarette flaring around the aperture has straight to finely serrate lips. The most discriminating character concerns the five to six quite short processes developed on the rounded margin. These cell-like processes originate from a peculiar multirooted structure (Plate XV, 7b) composed of ca. four short proximal "roots" directly fixed to the vesicle and merging into two distinct longer branches, which join themselves into a 
slender hollow process. This pattern is not visible on the paratype (Plate $\mathrm{XV}, 3$ ) because the chamber walls hide the proximal connection of the preserved processes. The presence of these multi-rooted processes and their "spongy" to cell-like internal structure is easily visible in transmitted light microscopy. The processes have a peculiar profile with a curved short proximal part oriented at $45^{\circ}$ with regard to the longitudinal axis of the vesicle and becoming parallel to this axis in the remaining part ("lyre-like" aspect).

Measurements (Table 12; Figs. 18a-b).

\begin{tabular}{|l|l|l|l|l|l|l|}
\hline & L & Lc & Dp & Dc & Dcoll. & l. processes \\
\hline Holotype & 254.6 & 174.2 & $(63.6)$ & $(26.8)$ & $(38.5)$ & 46.9 \\
& & & $* 50.9$ & $* * 18.7$ & $* * 27.0$ & \\
\hline Mean & 271.6 & 197.5 & $(73.2)$ & $(29.2)$ & $(41.4)$ & 49.8 \\
& & & $* 58.5$ & $* * 20.5$ & $* * 29.0$ & \\
\hline Maximum & 348 & 281 & $(85.4)$ & $(36.8)$ & $(53.6)$ & 80.4 \\
& & & $* 68.3$ & $* * 25.8$ & $* * 37.5$ & \\
\hline Minimum & 177.5 & 110.6 & $(60.3)$ & $(23.5)$ & $(33.5)$ & 23.5 \\
& & & $* 48.2$ & $* * 16.4$ & $* * 23.5$ & \\
\hline
\end{tabular}

Table 12: Biometric data (micrometers) for Plectochitina lucasi sp. nov. Means are based on 36 compressed specimens from the Baq'a-3 core hole, core 30 at $271.8 \mathrm{ft}$ depth (raw data: between brackets; $*$ correction factor: $0.8 ; * *$ correction factor: 0.7$)$.

Discussion: Plectochitina lucasi sp. nov. is one of the numerous Plectochitina with multirooted processes. In the present case, however, the rooting is rather short and is different from the rooting of the processes of $P$. alisawyiahensis sp. nov. (see above). Ancyrochitina species with large hollow processes (e.g. A. fragilis Eisenack, 1955a or A. magna Nestor, 1982) have 
frequently longitudinal cracks near the connection of these processes on the margin. These cracks to some extent may mirror the rooting of $P$. lucasi sp. nov. Among the long-necked Silurian Plectochitina species, P. clathrospinosa (Eisenack, 1968) has wide multi-rooted processes with very short and thin distal part (an assignment to Plectochitina is preferred here for this species; see Table 22). The general outline of the vesicle of A. parafragilis Al-Hajri and Paris, 1998 from the Sharawra Member is similar to that of A. lucasi sp. nov. but its chamber is more pear-shaped and its robust hollow processes have no multi-rooted proximal attachment, nor a cell-like internal structure. A. alhajrii sp. nov. is different in that it has processes without a spongy or vesicular internal structure.

In the upper part of the Baq'a-3 core hole, fairly long-necked chitinozoans have a silhouette similar to that of P. lucasi sp. nov. They are identified Plectochitina cf. lucasi and are differentiated from P. lucasi sp. nov. by their short and slender multi-rooted processes (Plate XVIII, 1b, 2b). Moreover, granules or cones are present on their chamber and neck (Plate XVIII, 1a, 1b).

Range and geographic distribution: P. lucasi sp. nov. is abundant in the Baq'a-3 well from 250.5 to $289.1 \mathrm{ft}$ (cores 27 to 32 ). It is the dominant species at $271.8 \mathrm{ft}$ (63\% of the recorded chitinozoans; see Fig. 8). P. lucasi sp. nov. is the index species of the eponymous subbiozone. This lucasi subbiozone is representative of the lower part of the obtusa Biozone referred to the Telychian (likely mid- to late Telychian; see stratigraphic discussion above, and Fig. 9). Identical chitinozoan specimens were recorded in the ISWH EW-9 well, in cutting samples from $3478 \mathrm{ft}$ to $3596.3 \mathrm{ft}$ (1058 $\mathrm{m}$ to $1094 \mathrm{~m}$ ) (Paris, 1993; pl. 2, figs. 1-2). These specimens provisionally called Ancyrochitina n. sp. B by Paris (1993) are included in the synonymy list of P. lucasi sp. nov. The corresponding samples from the ISWH EW-9 well are assigned to the lucasi subbiozone and are therefore of Telychian age (Fig. 9). 
Subfamily Angochitininae Paris, 1981

Genus Fungochitina Taugourdeau, 1966

Type species: Conochitina fungiformis Eisenack, 1931.

Fungochitina merrelli sp. nov. Paris (Plate IX, 1, 3; Plate X, 5)

? 1988 - Sphaerochitina lepta Jenkins, 1970; McClure, pl. VIII, figs. 11-12.

? 1991 - Ancyochitina merga Jenkins, 1970; Al-Hajri, pl. 30, figs.1-2, 4.

2005 - Angochitina milleri n. sp. nomen nudum; Paris, pl. 3, figs. 1, 3; pl. 4, figs. 5a-b.

Derivation of the name: The new specie is dedicated to Mr Merrell Miller for his long collaboration and his extensive studies on the Saudi Arabian palynomorphs.

Holotype: Plate IX, 1, core 49, sample from $450.1 \mathrm{ft}$, IGR 72340 (R45).

Type locality: Baq'a-3 core hole, North Central Saudi Arabia.

Type stratum: Qusaiba Member of the Qalibah Formation; core 49, sample from $450.1 \mathrm{ft}$, early Telychian.

Paratypes: Plate IX, 3, core 49, sample from 450.1 ft, IGR 72340 (S45/3); Plate X, 5, core 9, sample from $450.1 \mathrm{ft}$, IGR $72340(\mathrm{Q} 45 / 4)$.

Material: 13 specimens picked in the organic residues from cores 7 and 15 in the Baq'a-4 core hole (about 120 specimens in the remaining unpicked residues; see Table 2). 13 specimens picked in the organic residues from cores 47 to 49 in the Baq'a-3 core hole (about 43 in the remaining unpicked residues; Table 3). 
Diagnosis: Small Fungochitina species with a flat-based conical chamber and a short

cylindrical neck; conspicuous flexure; rounded margin; well-developed simple or "lambdatype" spines randomly arrayed on the vesicle, but longer near the margin.

Description: This small species (L ranging from ca. $94 \mu \mathrm{m}$ to $138 \mu \mathrm{m}$; mean length: 111.2 $\mu \mathrm{m}$; length of the holotype: $123.8 \mu \mathrm{m}$; see Table 13; Figs. 19a-b) has a thickset conical chamber with walls tapering rapidly toward a conspicuous flexure. The flanks are straight (no shoulder observed). The margin is rounded but this character as well as the flat bottom may be variously modified during the compression (Plate IX, 1, 3). The cylindrical neck is short (less than half of the total vesicle length) and shows a straight to weakly serrate aperture. The flaring aspect of the neck of the specimen illustrated on Plate IX, 3 is due to its twisted and folded wall. The discriminating character is the spiny ornamentation randomly distributed on the vesicle. These spines are generally simple, but some of them have a widened proximal part or a "lambda-type" insertion on the vesicle wall. These tapering spines or hairs (Plate X, $5 \mathrm{~b}$ ) are quite long (maximum length up to $15 \mu \mathrm{m}$ ). This ornamentation is better developed on the margin and on the lower half of the flanks. The spines are much shorter on the neck and on the bottom of the chamber and they are simple cones near the aperture (Plate IX, 1). Measurements (Table 13; Figs. 19a-b).

\begin{tabular}{|l|l|l|l|l|l|l|}
\hline & L & lc & Dp & dc & dcoll. & l. spines \\
\hline Holotype & 123.8 & 53.3 & $\begin{array}{l}(102.2) \\
* * 71.6\end{array}$ & $\begin{array}{l}(40.0) \\
* * 28.0\end{array}$ & $\begin{array}{l}(41.0) \\
* 32.8\end{array}$ & 6.7 \\
\hline Mean & 111.2 & 45.6 & $(84.6)$ & $(34.5)$ & $(38.2)$ & 7.2 \\
& & & $* 67.7$ & $* * 24.2$ & $* * 26.8$ & \\
\hline Maximum & 137.4 & 60.3 & $(102.2)$ & $(40.2)$ & $(46.9)$ & 13.4 \\
& & & $* * 71.6$ & $* * 28.2$ & $* * 32.9$ & \\
\hline Minimum & 93.8 & 33.5 & $(72.1)$ & $(26.8)$ & $(26.8)$ & 3.5 \\
\hline
\end{tabular}




\begin{tabular}{|l|l|l|l|l|l|l|}
\hline & & & $* 57.7$ & $* * 18.8$ & $* * 18.8$ & \\
\hline
\end{tabular}

Table 13: Biometric data (micrometers) for Fungochitina merrelli sp. nov. Means are based on 13 compressed specimens from the Baq'a-3 core hole, at $450.1 \mathrm{ft}$ depth and 9 specimens from the Baq'a-4 core hole core at 120.1 and $40.1 \mathrm{ft}$ (raw data: between brackets; *correction factor: $0.8 ; * *$ correction factor: 0.7$)$.

Discussion: Angochitina and Fungochitina genera are both spiny Lagenochitinidae, which have respectively an ovoid and a conical to lenticular chamber (Paris et al., 1999).

Fungochitina species normally have a flat bottom and a fairly sharp margin. In the present material, depending on the vesicle compression, the chamber bottom also seems flat, but this character is possibly accentuated by folding of the base into the chamber (Plate IX, 1; Plate X, 5a). The lateral compression has also accentuates the apparent width of the holotype and a coeff. of 0.7 has been used when restoring its chamber diameter (see Table 13). This small species could alternatively be attributed either to Fungochitina or to Angochitina and originally it was as a nomen nudum assigned to Angochitina because the hair-like ornamentation is more commonly observed in this genus. However, during the course of a revision of the Angochitininae, the new species merrelli is attributed to Fungochitina, in order to fit with the "compact" diagnosis of this genus in Paris et al. (1999). Al-Hajri (1991, pl. 29, figs. 2-4; pl. 30, figs. 1-2, 4) has illustrated and described specimens similar to $F$. merrelli sp. nov. Some of these specimens display longer spines on the margin (e.g. pl. 29, figs. 2-4) suggesting an assignment to Ancyrochitina. The two specimens from the Qusaiba Member of the Tabuk and Qasim areas illustrated by McClure (1988) under the name "Sphaerochitina lepta" (see synonymy) seem comparable to F. merrelli sp. nov. The illustration, however, does not permit a confident assignment to our new species. 
The silhouette of F. merrelli sp. nov. is comparable with that of some Devonian Fungochitina species, such as F. pilosa (Collinson and Scott, 1958) or F. hispida (Taugourdeau and de Jekhosky, 1960), which have more robust spines and longer necks. F. bernesgae (Cramer, 1967) from the Silurian of Spain has shorter spines and a better developed neck. $F$. illinoisensis Butcher, Mikulic and Kluessendorf, 2010 from the Rhuddanian of the Illinois, USA, has a larger vesicle, more robust conical spines and a flared collarette.

In the Qusaiba-1 core hole, specimens provisionally identified as Fungochitina? sp. aff. $F$. merrelli sp. nov. (Fig. 6; Table 19) were recorded in core 22 at $210.9 \mathrm{ft}$ (Plate III, 4a-b) and in core 15 at $145.9 \mathrm{ft}$ (Plate $\mathrm{V}, 4,8 \mathrm{a}-\mathrm{b}$ ). Their spiny ornamentation is more densely distributed than in the F. merrelli sp. nov., their ratio Dp/dc is lower and the spines seem better developed on the margin (Plate III, 4b). The last character to some extent evokes Ancyrochitina species (see McClure, 1988).

Range and geographic distribution: F. merrelli sp. nov. is recorded in the upper part of the Qusaiba Member in the Baq'a-4 and Baq'a-3 core holes (Figs. 7-8). This restricted distribution makes it suitable as the index species of the merrelli total-range subbiozone characterizing the upper part of the macclurei Biozone. The occurrence of F. merrelli with graptolites of the guerichi Biozone allows an age assignment of the corresponding strata to the early Telychian. F. merrelli sp. nov. is possibly represented (see synonymy above) in the Qusaiba Member of the Qalibah Formation in well "QA" of the Tabuk area (A1-Hajri, 1991; McClure, 1988).

Genus Muscochitina Paris, 1981 
Muscochitina olivieri sp. nov. Paris (Plate I, 1, 4, 6)

v. 1991 - Sphaerochitina sp. indet.; Paris, pl. 1, figs. 7a-b.

v. 1992 - Sphaerochitina sp. indet.; Paris, fig. 6.

v. 2005 - Muscochitina sp. nov. 1; Paris, pl. 6, figs. 1a-b, 4a-c.

Derivation of the name: The species is dedicated to my son Olivier Chang Paris, for his help in preparing my photographic plates, drawings and databases.

Holotype: Plate I, 4, core 27, sample at $251.1 \mathrm{ft}, \mathrm{IGR} 72253,(\mathrm{O} 49)$.

Type locality: Qusaiba-1 core hole, core 27, North Central Saudi Arabia.

Type stratum: Qusaiba Member of the Qalibah Formation, core 27, $251.1 \mathrm{ft}$, mid Aeronian (upper part of the qusaibaensis Biozone)

Paratype: Plate I, 1, core 27, sample at $251.1 \mathrm{ft}$, IGR 72253, (M44/1).

Material: 58 picked specimens from the organic residue of Qusaiba-1 core 27 at $251.1 \mathrm{ft}$, and about 240 additional specimens in the remaining unpicked residue (see Table 1)

Diagnosis: Muscochitina species with a flaring neck, well-differentiated from the ovoid to spherical chamber; vesicle covered with a mesh-like structure composed of thin threads radiating from dispersed short pillars or knobs.

Description: This medium sized Muscochitina species with a vesicle length (L) ranging from ca. $110 \mu \mathrm{m}$ to $195 \mu \mathrm{m}$ (L holotype: $147.4 \mu \mathrm{m}$; mean: $140.1 \mu \mathrm{m}$; see Table 14, Figs. 20a-b) has a well-developed flaring neck separated from the chamber by a conspicuous flexure. The shoulder is fairly weak as the chamber is ovoid to sub-spherical, especially when the wall is folded during the compression of the vesicle (Plate I, 4a). The neck gently flares aperturalwards, and represents one third to one half of the total vesicle length (length the neck 
of the holotype: $1 \mathrm{c}=67 \mu \mathrm{m})$. The lips around the aperture are straight or slightly notched (Plate I, 1a). The distinctive character of this species is the peculiar elevated mesh covering the whole vesicle. This ornamentation is composed of finial structures (fleuron-like) made of thin radial threads diverging from a central connection point or knot (Plate I, 1b, 4b-c). These connection points are fixed to the vesicle wall through very short pillars fairly regularly dispersed on the vesicle. The slender threads (up to ten threads per finial structure) taper distally (Plate I, 4c). This mesh-like ornamentation fades away on the neck. The mesh may trap small particles (Plate I, 1b, 4b-c) and thus simulates a granular wall surface in transmitted light microscopy.

Measurements (Table 14; Figs. 20a-b).

\begin{tabular}{|l|l|l|l|l|l|}
\hline & L & Lc & Dp & Dc & Dcoll. \\
\hline Holotype & 147.4 & 67 & $(82.1)$ & $(50.3)$ & $(53.6)$ \\
& & & $* 65.7$ & $* * 35.2$ & $* * 37.5$ \\
\hline Mean & 140.1 & 59.5 & $(77.2)$ & $(38.1)$ & $(44.0)$ \\
& & & $* 61.8$ & $* * 26.7$ & $* * 30.8$ \\
\hline Maximum & 194.3 & 90.5 & $(87.1)$ & $(50.3)$ & $(53.6)$ \\
& & & $* 69.7$ & $* * 35.2$ & $* * 37.5$ \\
\hline Minimum & 110.6 & 40.2 & $(50.3)$ & $(28.5)$ & $(33.5)$ \\
& & & $* 40.3$ & $* * 20.0$ & $* * 23.5$ \\
\hline
\end{tabular}

Table 11: Biometric data (micrometers) for Muscochitina olivieri sp. nov. Means are based on 37 compressed specimens from the Qusaiba-1 core hole, core 27 at $251.1 \mathrm{ft}$ depth (raw data: between brackets; *correction factor: $0.8 ; * *$ correction factor: 0.7$)$.

Discussion: Muscochitina muscosa Paris, 1981 has a better-developed neck and its ornamentation is made of a regularly and densely meshed network. The mesh-like 
ornamentation of Muscochitina samiri Boumendjel, 2002 is restricted to the margin and is not arranged in finial structures. When the finial ornamentation is eroded, M. olivieri sp. nov. may be confused with Sphaerochitina solitudina Paris, 1988 b as only granules corresponding to the scars of the minute pillars are preserved on the wall surface (see Plate I, 6). Because the tiny threads of the finial structures, SEM observations are required for identifying this new species.

Range and geographic distribution: In the Qusaiba-1 core hole, Muscochitina olivieri sp. nov. occurs in core 27 , at $251.1 \mathrm{ft}$ where it is abundant. Very rare specimens are also recorded in core 26 at $248.3 \mathrm{ft}$. The new species seems restricted to the upper part of the qusaibaensis chitinozoan biozone assigned to the mid Aeronian on graptolite evidence (convolutus Biozone; see discussion above). M. olivieri sp. nov. was also reported under the provisional name "Sphaerochitina sp. indet." from core 17, at $16635.7 \mathrm{ft}$ depth in the UDYN-1 well (Paris, 1991), and from core 20, at $16872 \mathrm{ft}$ depth in the TINT-2 well (Paris, 1992). The occurrence of $M$. olivieri sp. nov. allows a more refined correlation of parts of these two deep wells within the mid-Aeronian.

Order Operculatifera Eisenack, 1972

Family Desmochitinidae Eisenack, 1931, emend Paris, 1981

Subfamily Desmochitininae Paris, 1981

Genus Bursachitina Taugourdeau, 1966 
Type species: Desmochitina bursa Taugourdeau and de Jekhowsky, 1960

Bursachitina baqaensis sp. nov. Paris (Plate VIII, 3)

2005 - Bursachitina baqaensis nomen nudum; Paris, pl. 2, fig. 3.

Derivation of the name: from the Baq'a locality in north-western Central Saudi Arabia, where the Baq'a-4 core hole was drilled.

Holotype: Plate VIII, 3, core 19, sample at 163.0 ft, upper vesicle, IGR 72364 (O46/1).

Type locality: Baq'a-4 core hole, core 19, north-western Central Saudi Arabia

Type stratum: Qusaiba Member of the Qalibah Formation, core 19, sample at $163.0 \mathrm{ft}$, late Aeronian (upper part of the hemeri Biozone).

Paratype: Plate VIII, 3, core 19, 163.0 ft, lower vesicle, IGR 72364 (O46/1).

Material: 32 isolated vesicles and four connected vesicles (as two twins) from core 19, at $163.0 \mathrm{ft}$ in the Baq'a-4 core hole.

Diagnosis: Bursachitina species with a distinct sharp margin; vesicle thick at margin and smooth; slightly convex base with a circular scar; thin collarette with finely serrate lips. Description: The observed vesicles are perfectly smooth (the granules on the lower specimen on Plate VIII, 3 are small mineral crystals that formed during the drying of the specimen). The vesicle is rather small ( $\mathrm{L}$ ranging from ca. $74 \mu \mathrm{m}$ to $164 \mu \mathrm{m}$; L holotype: $110.6 \mu \mathrm{m}$; Dp holotype near the margin: $97.2 \mu \mathrm{m}$ ) (Table 15; Fig. 21a). The rather thickset chamber (Dp close to lp; Fig. 21b) is conical with flanks gently tapering toward the collarette. This collarette (lcoll. ranging from $10 \mu \mathrm{m}$ to $50 \mu \mathrm{m}$ ) has membranous finely serrate lips. The imprint of the folded operculum is visible in the lower vesicle (Plate VIII, 3). It gives the original diameter of the aperture $(53 \mu \mathrm{m})$ prior to the compression, which altered the 
silhouette of the vesicle. The operculum corresponds usually to a fairly long cylindrical plug composed of a disc with a thin-walled rica (total length up to $30 \mu \mathrm{m}$ ). In specimens with a well-developed collarette, this operculum is located quite deep, near the chamber-collarette junction. In the available material, the collarette and most of the chamber are completely flattened but the fairly sharp margin, because of its thicker walls is less deformed. The differential compression due to differences in the thickness of the walls resulted in an accentuation of the convexity of the flanks (normally straight or slightly convex). As a consequence the wider part of the chamber is no longer on the margin (its original position before this differential compression) but moved towards the middle part of the chamber. The chamber bottom is slightly convex, but the original convexity is accentuated during the compression that caused the tear near the central callus of the lower vesicle (Plate VIII, 3). The callus has a wide rim (diameter close to $20 \mu \mathrm{m}$ ) surrounding a slightly depressed area. Measurements (Table 15; Figs. 21a-b).

\begin{tabular}{|c|c|c|c|c|c|}
\hline & $\mathrm{L}$ & $\mathrm{lp}$ & lcoll. & $\mathrm{Dp}$ & Dcoll. \\
\hline Holotype & 110.6 & 83.8 & 24.5 & $\begin{array}{l}(97.2) \\
* 77.8\end{array}$ & $\begin{array}{l}(60.3) \\
* * 42.2\end{array}$ \\
\hline Mean & 113.6 & 85.1 & 30.0 & $\begin{array}{l}(92.2) \\
* 73.8\end{array}$ & $\begin{array}{l}(60.4) \\
* * 42.3\end{array}$ \\
\hline Maximum & 164.0 & 137.4 & 50.3 & $\begin{array}{l}(120.6) \\
* 96.5\end{array}$ & $\begin{array}{l}99.2 \\
* * 69.5\end{array}$ \\
\hline Minimum & 73.7 & 57.0 & 10.1 & $\begin{array}{l}(73.7) \\
* 59.0\end{array}$ & $\begin{array}{l}(45.6) \\
* * 32.0\end{array}$ \\
\hline
\end{tabular}

Table 15: Biometric data (micrometers) for Bursachitina baqaensis sp. nov. Means are based on 36 flattened specimens from the Ba'qa-4 core hole, core 19, at $163.0 \mathrm{ft}$ depth (raw data: between brackets; *correction factor: $0.8 ; * *$ correction factor: 0.7$)$. 
Discussion: The length of the chamber (lp: vesicle length minus the well-developed collarette) of this new species is close to its width (mean ratio lp/Dp: 0.92 but approximately 1.15 when the flattening is corrected; see Table 15 and Fig. 21b). This leads to its assignment to the genus Bursachitina as Euconochitina has a lp/Dp ratio exceeding one. Only a few specimens with an unusually short collarette with regard to the chamber length have been recorded (see Fig. 21b). B. pachygaster (Taugourdeau, 1963), B. lagenicula Eisenack, 1971 and B. concava Eisenack, 1972 have sigmoid flanks and the two latter have a rounded margin. B. bursa (Taugourdeau and de Jekhowsky, 1960) and B. timpaniformis Tsegelnjuk, 1982 have a more thickset vesicle. The vesicle of $B$. nana (Nestor, 1994) from the early Silurian of Estonia is smaller.

Range and geographic distribution: Bursachitina baqaensis sp. nov. is only recorded in the Qusaiba Member in the Baq'a-4 well. It is rare at $180.4 \mathrm{ft}$ (core 21) but more abundant at $160.0 \mathrm{ft}$ (core 19). The corresponding samples are bracketed between strata yielding graptolites respectively of the convolutus and of the guerichi Zones. Consequently, they are referred to the late Aeronian (see Fig. 9).

Subfamily Cutichitininae Achab, Asselin and Soufiane, 1993

Genus Cutichitina Achab, Asselin and Soufiane, 1993

Type species: Cutichitina legrandi Achab, Asselin and Soufiane, 1993

Cutichitina minivelata sp. nov. Paris (Plate III, 9; Plate VI, 12) 
? 1988 - Pterochitina? perivelata (Eisenack, 1937); McClure, pl. VI, fig. 8.

? 1988 - Hoegisphaera complanata (Eisenack, 1932); McClure, pl. VI, fig. 13 (non fig. 12). 1991 - Pterochitina deichaii Taugourdeau, 1963; Al-Hajri, pl. 38, figs. 2-3, (non fig. 6).

v. 1992 - Calpichitina cf. densa Eisenack, 1962; Paris, pl. 1, fig. 5.

v. 2003 - Calpichitina n. sp. 1 (spongy); Paris, pl. 1, 12a-b; pl. 4, fig. 9.

v. 2005 - Pterochitina deichaii Taugourdeau, 1963; Paris, pl. 3, fig. 5.

Derivation of the name: The name refers to the short velum that covers the vesicle.

Holotype: Plate III, 9 (second vesicle from the top), core 24, sample at $228.8 \mathrm{ft}$, IGR 72264 (S46/1).

Type locality: Qusaiba-1 core hole, core 24, North Central Saudi Arabia.

Type stratum: Qusaiba Member of the Qalibah Formation, core 24, at $228.8 \mathrm{ft}$, mid-Aeronian (alargada Biozone)

Paratypes: Plate III, 9 (vesicles other than the holotype in the chain-like structure), core 24, at 228.8 ft, IGR $72264($ S46/4).

Material: Several hundred vesicles, mostly in chain-like structures with up to fifty connected vesicles in cores 14 to 27 from the Qusaiba-1 core hole (Fig. 6; Table 19) and in cores 21 to 40 from the Baq'a-3 core hole (Fig. 8; Table 21); several hundred additional specimens, mostly in chain-like structures, were recorded in the TINT-2 and UDYN-1 wells. Diagnosis: Small lenticular to thickset barrel-like vesicle without neck or collarette; felt-like to spongy membrane (velum) encapsulating the chamber; wide aperture with flat operculum; chain-like structure with resistant inter-vesicle connections.

Description: This very small chitinozoan (mean vesicle length close to $63 \mu \mathrm{m}$ ) has a lenticular chamber with rounded flanks and rather flat apertural and antiapertural surfaces. It usually 
occurs in long chain-like structures compressed laterally (Plate III, 9; Plate VI, 12). In that case, each vesicle looks like a very thickset barrel (L/Dp close to 0.5; see Table 16 and Fig. 22a). Important variations of the size and of the shape of the vesicles are noticed between different chain-like structures. This is obvious on Figure 22 a where the four chain-like structures used for the measurements appear as separate clusters. A slight difference is also recorded along each "chain" as illustrated on Figure 22b (see also Plate VI, 12a). Closer connected individuals occur at one extremity of the chain whereas the larger and betterseparated vesicles are at the end. This suggests that these chain-like structures correspond to early stages of a lay out (likely intra-oviduct connected ovules, according to the interpretation given by Paris and Nõlvak, 1999). No neck or collarette are present around the large aperture with a diameter about half size of the chamber, and which is closed by a discoid operculum (Plate III, 9). The antiapertural and apertural poles are usually difficult to identify because the folding and the buckling of the chamber hide the aperture in the catenary structures. The latter are extremely common in the recovered organic residues and indicate a strong intra-vesicle linkage. One of the distinctive features of this species is the spongy to felt-like outer layer extending laterally when the vesicles are totally flattened. This character is more visible in transmitted light microscopy. When the vesicles are severely compressed laterally, this unstuck thin-walled layer wraps the chamber and appears as a less opaque area surrounding chamber walls, especially along the flanks. This fairly transparent zone (only outer layer involved) can be shifted on one side of the vesicle during the compression and in that case it may be easily confused with the carina of a Pterochitina species (see discussion below). Measurements (Table 16; Figs. 22a-b).

\begin{tabular}{|l|l|l|l|}
\hline & L & Dp & l."sleeve” \\
\hline Holotype & 33.5 & 57.0 & 6.7 \\
\hline
\end{tabular}




\begin{tabular}{|c|c|c|c|}
\hline & & $* 45.6$ & \\
\hline Mean & 63.1 & $\begin{array}{l}(93.6) \\
* 74.7\end{array}$ & 10.5 \\
\hline Maximum & 57.0 & $\begin{array}{l}(124.0) \\
* 99.2\end{array}$ & 20.1 \\
\hline Minimum & 28.5 & $\begin{array}{l}(57.0) \\
* 45.6\end{array}$ & 5.1 \\
\hline
\end{tabular}

Table 16: Biometric data (micrometers) for Cutichitina minivelata sp. nov. Means are based on 53 compressed specimens from the Qusaiba-1 core hole, core 24 at $228.8 \mathrm{ft}$ and core 14 at $136.5 \mathrm{ft}$ depth (raw data: between brackets; *correction factor: 0.8 ).

Discussion: It may be tempting to assign the specimens recovered in core samples from the Qusaiba-1 and Baq'a-3 core holes either to Pterochitina or to Calpichitina, as these two genera have also a lenticular chamber (Paris et al., 1999). An extensive discussion of Cutichitina and Pterochitina, which may be easily confused when the vesicle are compressed, is given by Paris in Rickards et al (2010, p. 115). Concerning the Qusaiba material, the threedimensional reconstruction of the flattened vesicles leads to a preferred assignment to Cutichitina Achab, Asselin and Soufiane, 1993, even if this genus was created for the Desmochitinidae with an ovoid chamber (so far no genus has been created for the chitinozoans with a lenticular chamber surrounded by a detached velum). In all likelihood Cutichitina minivelata sp. nov. has been confused (see synonymy) with $P$. deichaii as their total-range overlaps. SEM observations prove that the specimens of P. deichaii (e. g., Plate II, 3a-b; Plate XVI, 8) associated with C. minivelata sp. nov. in the Qusaiba-1 core hole have a different flattening pattern, and display a disk-like aspect when flattened and even buckled (Plate II, 3a-b). The specimen illustrated by McClure (1988, pl. VI, fig. 13) as H. complanata 
may be a $C$. minivelata sp. nov. compressed laterally as some spongy remains seem present on the flanks. The specimen tentatively referred to P. perivelata by McClure (1988, pl. VI, fig. 8) is axially compressed and is surrounded by a spongy structure recalling that of $C$. minivelata sp. nov. Some specimens are puzzling such as the three vesicles illustrated on Plate IX, 5 and assigned to $P$. deichaii. They have a spongy surface but in transmitted light microscopy, a carina is visible on the lower vesicle, which shows in addition a short collarette around a narrow aperture.

C. minivelata sp. nov. is abundant in core 17 from the UDYN-1 well and in cores $18-20$ from TINT-2 well (see synonymy) where it was provisionally referred to Calpichitina $\mathrm{cf}$. densa (Paris, 1991,1992). Calpichitina Wilson and Hedlund, 1964 was indeed an alternative generic assignment for the Qusaiba specimens because their lenticular chamber (see synonymy list). Moreover, Calpichitina may have a spongy surface, e.g., C. spongiloricata (Wrona, 1980) but no completely separated membrane is reported in this genus. Other Calpichitina species have partly folded outer layer, e.g. C. squamosa (Laufeld, 1974) from the Ludlow of Gotland, or $C$. velata (Wrona, 1980), from the upper Silurian of Poland. Both species have a membranous collarette and are not commonly arranged in resistant chain-like structures like Cutichitina minivelata sp. nov. The specimen recorded in the Baq'a-3 core hole at $350.0 \mathrm{ft}$ (Plate XIII, 6) has a spongy outer layer stuck on the chamber. It is tentatively assigned to Cutichitina minivelata sp. nov.

Range and geographic distribution: Cutichitina minivelata sp. nov. is a rather long ranging species, which is irregularly distributed in the Qusaiba Member of the Qalibah Formation in the Qusaiba-1 and in the Baq'a-3 core holes (Figs. 6 and 8). The corresponding strata are assigned to the Aeronian and to the Telychian pro parte. Based on the proposed synonymy, the new species is most likely present in the Qusaiba Member of the Qalibah Formation in the subsurface of the Qasim area in samples 6a and 7a from the "QU" well (Al-Hajri, 1991). C. 
minivelata sp. nov. is abundant in the upper part of core 17 from the UDYN-1 well and in cores 17 to 20 in the TINT-2 well (Paris, 1991, 1992). Based on the present calibration of the chitinozoans of the Qusaiba Member by graptolites (Zalasiewicz et al., 2007), the corresponding strata are assigned to the mid-Aeronian to early Telychian (Fig. 9).

Subfamily Pterochitininae Paris, 1981

Genus Armoricochitina Paris, 1981

Type species: Linochitina ? ceneratiensis Paris, 1976.

Armoricochitina crassicarinata sp. nov. Paris (Plate XI, 2; Plate XII, 2, 6; Plate XIV, 7)

1988 - Linochitina cingulata (Eisenack, 1937); McClure, pl. VII, fig. 2.

? 1991 - Armoricochitina nigerica (Bouché, 1965); Al-Hajri, pl. 26, figs. 1-2, 4 (non fig. 3). 1993 - Armoricochitina ? n. sp. A; Paris, pl. 2, figs. 4-5.

2005 - Armoricochitina crassicarinata nomen nudum; Paris pl. 5, 2; pl. 6, figs. 2, 6; pl. fig. 7.

Derivation of the name: the name refers to the thickness (Latin "crassus" for thick) of the carina.

Holotype: Plate XII, 2; core 40, sample from 370.4 ft, IGR 72332 (S48/1).

Type locality: Baq'a-3 core hole, core 40, north-western Central Saudi Arabia

Type stratum: Qusaiba Member of the Qalibah Formation, core 40, $370.4 \mathrm{ft}$, early Telychian (upper part of the macclurei Biozone). 
Paratypes: Plate XII, 6; core 40, sample from 370.4 ft, IGR 72332 (Q48/2).

Material: 166 picked vesicles from the organic residues from the Baq'a-3 cores 36 to 45 (Fig. 8; Table 21) and several hundred specimens in the corresponding unpicked organic residues (see Table 3).

Diagnosis: Small Armoricochitina species with a thick-walled ovoid chamber; weakly corrugated walls; short membranous collarette; thickened carina below the margin.

Description: This species shares all the characters of the genus Armoricochitina. The ovoid to pear-shaped chamber has a slightly convex bottom but this aspect is frequently hidden when the bottom wall is folded inwards the chamber in laterally compressed vesicles. The larger diameter is situated over the lower third of the chamber. The chamber width (Dp) represents about three quarter of the vesicle length (L) (Fig. 23a; mean L/Dp is close to 1.35; L/Dp of the holotype=1.26). The vesicle wall is quite thick (ca. $3 \mu \mathrm{m}$; the thickness is measured on the lower vesicle on Plate XII, 6). Its surface shows a corrugated pattern (minute depressions; see Plate XI, 2b) fading away toward the aperture. The flat discoid operculum is located at the base of a thin-walled cylindrical (Plate XII, 6) to gently flaring collarette (Plate XII, 2). The variable development of the collarette (up to $82.5 \mu \mathrm{m}$ length) intervenes in the general silhouette of the vesicle, especially in the few longer individuals recorded (Table 17, Fig. 23b). The most discriminating character is the thick and very short carina (mean length about $3.5 \mu \mathrm{m}$ ) located just below the margin (Plate XII, 2; Plate XIV, 7). The carina has a rounded distal border and may look like a rim (Plate XI, 2b). Occasionally, some "twins" have been observed (inter-vesicle linkage by simple juxtaposition; see, Plate XII, 6). A small scar exists on the apex of the vesicle.

Measurements (Table 17; Figs. 23a-b).

\begin{tabular}{|l|l|l|l|l|l|}
\hline & L & lcoll. & Dp & dcoll. & l carina \\
\hline
\end{tabular}




\begin{tabular}{|l|l|l|l|l|l|}
\hline Holotype & 117.3 & 23.5 & $\begin{array}{l}(93.2) \\
* 74.6\end{array}$ & $\begin{array}{l}(60.3) \\
* * 42.3\end{array}$ & 3.5 \\
\hline Mean & 123.6 & 33.0 & $\begin{array}{l}(91.9) \\
* 73.5\end{array}$ & $\begin{array}{l}(57.7) \\
* * 40.4\end{array}$ & 3.5 \\
\hline Maximum & 198.0 & 82.5 & $(120.6)$ & $(80.4)$ & 6.7 \\
\hline Minimum & 83.8 & 6.7 & $* 96.5$ & $* * 56.3$ & \\
\hline & & & $* 57.0)$ & $(43.6)$ & 1.7 \\
\hline
\end{tabular}

Table 17: Biometric data (micrometers) for Armoricochitina crassicarinata sp. nov. Means are based on 45 compressed specimens from the Ba'qa-3 core hole, core 40 at $370.4 \mathrm{ft}$ depth (raw data: between brackets; *correction factor: $0.8 ; * *$ correction factor: 0.7 ).

Discussion: As frequently observed in Armoricochitina species (e.g. A. nigerica; see Paris et al., this volume), significant intraspecific morphological variations are noticed in the recovered populations of $A$. crassicarinata sp. nov. These variations concern mainly the length of the collarette (Fig. 23b). They may also implicate the development of the carina (slightly longer or thinner in some specimens) and the degree of curving of the sigmoid flanks. This curving may modify significantly the outline of the vesicles (e.g., holotype on Plate XII, 2, versus paratype, Plate XII, 6). The resulting variable morphologies are regarded as simple intraspecific fluctuations as no trend through time is observed.

Only a few other Armoricochitina have been described. Compared to A. crassicarinata sp. nov., A. nigerica (Bouché, 1965) from the Late Ordovician of northern Gondwana has a better-developed membranous carina and bears small granules on its wall (see Paris et al., this volume). A. armoricana (Rauscher and Doubinger, 1967) is a Darriwilian species with a more 
slender vesicle and a better developed carina. A. ceneratiensis (Paris, 1976) from the Lower Devonian of Brittany has a more ovoid chamber and smooth walls.

In the Baq'a-3 well, a few specimens with a long neck/collarette are provisionally referred to A. cf. crassicarinata sp. nov. (Plate XIII, 7) as they may be end members of a polymorphic population (Figs. 23a-b). To some extents, the silhouette of $A$. cf. crassicarinata sp. nov. (Plate XIII, 7) is reminiscent of those of A. armoricana (Rauscher and Doubinger, 1967) or of A. granulifera Nõlvak and Grahn, 1993. A. crassicarinata sp. nov. is distinguished from $A$. gengi sp. nov. by its thick rim-like carina (see discussion of $A$. gengi sp. nov. below). Some Armoricochitina illustrated by Al-Hajri (1991, pl. 26, figs. 1-2, 4) from the Tabuk area (sample 9 from well "QA") have a short and fairly thick carina similar to that of $A$. crassicarinata sp. nov. They are therefore tentatively included in its synonymy list (see above).

Range and geographic distribution: A. crassicarinata sp. nov. may be abundant in the Qusaiba Member of the Qalibah Formation in the Baq'a-3 core hole (24\% of the recorded chitinozoans at $350.1 \mathrm{ft}$; Fig. 8). In this well it ranges at least over $78.3 \mathrm{ft}(23.8 \mathrm{~m})$ from core 36 to core 45 and likely more as there is ca. $23 \mathrm{ft}(7 \mathrm{~m})$ separating these cores from the closest ones devoid of $A$. crassicarinata sp. nov. (Fig. 8; Table 21). This new species is selected as the index species of a subbiozone characterizing the upper part of the macclurei Biozone. This crassicarinata subbiozone is assigned to the early Telychian as the corresponding strata yield graptolites of the turriculatus Biozone (Fig. 9; see discussion above).

If one accepts the synonymy proposed here, A. crassicarinata sp. nov. occurs in cutting samples of the ISWH EW. 9 well from $3517.4 \mathrm{ft}$ to $3602.9 \mathrm{ft}$ (1070 m to $1096 \mathrm{~m}$ ) (Paris, 1993). In this well, it is the dominating species in the core samples at $3594.7 \mathrm{ft}$ to $3609.5 \mathrm{ft}$. (1093.5 $\mathrm{m}$ to $1098 \mathrm{~m}$ ), which therefore have an early Telychian age.

The new species is probably also present in the Qusaiba Member of the Qalibah Formation in 
the subsurface of the Tabuk area (sample 9 from well "QA").

Armoricochitina gengi sp. nov. Paris (Plate XV, 1; Plate XVIII, 5)

1993 - Armoricochitina n. sp. aff. A. panzuda (Cramer, 1964); Paris, pl. 2, fig. 3.

1988 - Cyathochitina sp.; McClure, pl. VII, fig. 11.

Derivation of the name: this new species is dedicated to Professor Geng Liang-Yu (Nanjing, China) for his impressive work on the Silurian chitinozoans from China.

Holotype: Plate XV, 1; core 27, sample from 250.5 ft, IGR 72316 (S45/1).

Type locality: Baq'a-3 core hole, core 27, at $250.5 \mathrm{ft}$, north-western Central Saudi Arabia Type stratum: Qusaiba Member of the Qalibah Formation, core 27, at $250.5 \mathrm{ft}$, Telychian (obtusa Biozone).

Material: Sixteen picked specimens from the organic residue from $250.5 \mathrm{ft}$ (core 27) and 62 specimens from $150.4 \mathrm{ft}$ (core 16) in the Baq'a-3 core hole (Table 3, Fig. 8); about 600 specimens in the corresponding unpicked organic residues.

Diagnosis: Armoricochitina species with a conical to pear-shaped chamber; walls fairly thick with a weakly corrugate surface; membranous carina located closely below the margin; chamber bottom gently convex.

Description: This new species has gently tapering flanks with an inflexion of their convergence over the middle part of the chamber. Because important variations in the development of the neck/collarette (lcoll. is measured from this inflexion to the border of the lips; Table 18; Fig. 24b), the total length of the vesicle (L) shows greater variations than the chamber width (Table 18; Fig. 24a). The sigmoid profile of the flanks may be deeply 
modified by differential compression of the vesicle. When totally flattened (Plate XV, 1), the maximum width of the chamber fits with the margin, whereas when the lower part of the chamber is not totally flattened the maximum width is situated at the lower forth or fifth of the vesicle length (Plate XVIII, 5). The surface of the rather thick chamber wall displays small corrugations generating a "wavy" pattern more or less parallel to the margin. The thickness of the chamber wall (ca. $2.5 \mu \mathrm{m}$ ) is visible on lateral cracks of the compressed holotype (Plate $\mathrm{XV}, 1)$. A membranous collarette with straight lips surrounds the aperture. The chamber bottom is slightly convex but this character may be modified when the bottom wall is folded into the chamber in compressed vesicles. A membranous carina (mean length ca. $13 \mu \mathrm{m}$ ) is located just below the margin. This critical taxonomical character is sometime difficult to evaluate on compressed specimens, e.g. the holotype (Plate $\mathrm{XV}, 1$ ), or when the carina is folded up on the margin (Plate XVIII, 5). A circular scar (not visible on the illustrated material) occurs on the bottom of the chamber.

Measurements (Table 18; Figs. 24a-b).

\begin{tabular}{|l|l|l|l|l|l|}
\hline & L & lcoll. & Dp & Dcoll. & l carina \\
\hline Holotype & 140.7 & 73.7 & $\begin{array}{l}(105.6) \\
* 84.5\end{array}$ & $\begin{array}{l}(67.0) \\
* * 46.9\end{array}$ & 16.8 \\
\hline Mean & 142.1 & 69.5 & $(99.6)$ & $(65.2)$ & 13 \\
& & & $* 79.7$ & $* * 45.7$ & \\
\hline Maximum & 190.0 & 90.5 & $(118.9)$ & $(77.1)$ & 18.5 \\
& & & $* 95.2$ & $* * 54.0$ & \\
\hline Minimum & 90.5 & 43.6 & $(77.1)$ & $(50.3)$ & 6.7 \\
& & & $* 61.7$ & $* * 35.2$ & \\
\hline
\end{tabular}


Table 18: Biometric data (micrometers) for Armoricochitina gengi sp. nov. Means are based on 16 compressed specimens from the Ba'qa-3 core hole, core 27 at $250.5 \mathrm{ft}$ depth (raw data: between brackets; *correction factor: $0.8 ; * *$ correction factor: 0.7$)$.

Discussion: An assignment to the genus Armoricochitina rather than to Cingulochitina is preferred because the widest part of the chamber is above the margin. In addition, the chamber wall is fairly thick and displays micro-corrugations. Both are features uncommon in Cingulochitina species.

A. gengi sp. nov. is similar to A. crassicarinata sp. nov., but the latter has a distinct thick rimlike carina. A. panzuda (Cramer, 1964) from the Emsian of northern Gondwana regions (Paris et al., 2000) has a carina located well below the margin. A. gengi sp. nov. resembles several Silurian Cingulochitina species with a short carina. C. burdinalensis Verniers, 1999 and $C$. bouniensis Verniers, 1999 have a more ovoid chamber. C. serrata (Taugourdeau and de Jekhowsky, 1960) has a smooth wall, a more convex chamber bottom and a mucron. The chitinozoan "chain" recorded at $350.1 \mathrm{ft}$ in the Baq'a-3 well, and provisionally identified Armoricochitina? sp. (Plate XIII, 2) possibly represents teratologic specimens (thickset vesicles) of $A$. gengi sp. nov.

Other individuals, possibly belonging to this new species, are provisionally identified Armoricochitina cf. gengi sp. nov. (Plate XVII, 1-2) because the characteristic features, i.e. the membranous carina or the corrugated wall surface are less obvious (Plate XVII: 1a, 2a). The large circular rim on their convex bottom (Plate XVII, 1b, 2b) suggests that they were usually arranged in chain-like structures such as the "twins recorded" at $350.5 \mathrm{ft}$ (Plate XIII, 2).

Range and geographic distribution: In the Baq'a-3 core hole, A. gengi sp. nov. is recorded in the upper part of the Qusaiba Member of the Qalibah Formation from core 27 to core 16 
where it is more common (Fig. 8; Table 21). The species ranges through the obtusa and the silurica biozones, which are referred to the Telychian (see Fig. 9 and the stratigraphical discussion above).

A. gengi sp nov. is very rare and irregularly represented in the ISWH EW-9 well. It was provisionally called "Armoricochitina n. sp. aff. panzuda" (see synonymy) and occurs in cutting samples from $3254.5 \mathrm{ft}$ to $3576.6 \mathrm{ft}$ (990 m to $1088 \mathrm{~m}$ ) (Paris, 1993).

Appendix C. Lithostratigraphy, chronostratigraphy, biozonation of the investigated samples and range of the recorded chitinozoans (Tables 19-21)

Appendix D. List of the cited chitinozoans (Table 22)

Ancyrochitina aculeata Taugourdeau and de Jekhowsky, 1960

Ancyrochitina alhajrii sp. nov. Paris

*Ancyrochitina ansarviensis Laufeld 1974

Ancyrochitina camilleae sp. nov. Paris

*Ancyrochitina diabolo Eisenack, 1937

*Ancyrochitina erichseni Sommer and Van Boekel, 1963

*Ancyrochitina fragilis Eisenack, 1955a

*Ancyrochitina longispina Achab, 1978

*Ancyrochitina magna Nestor, 1982

*Ancyrochitina merga Jenkins 1970

*Ancyrochitina obesa Tsegelnjuk, 1982

*Ancyrochitina parafragilis Al-Hajri and Paris, 1998 
*Ancyrochitina porrectaspinosa Nestor, 1994

*Ancyrochitina ramosaspina Nestor, 1994

*Ancyrochitina spinosa Al-Ameri, 1989

Ancyrochitina cf. aculeata Taugourdeau and de Jekhowsky, 1960

*Ancyrochitina cf. longispina Achab, 1978

*Ancyrochitina cf. ramosaspina Nestor, 1994

Ancyrochitina gr. aculeata Taugourdeau and de Jekhowsky, 1960

Ancyrochitina gr. ancyrea (Eisenack, 1931)

*Ancyrochitina $\mathrm{n}$. sp. B

Ancyrochitina sp.

Angochitina hemeri Paris and Al Hajri, 1995

Angochitina hemeri? Paris and Al Hajri, 1995

Angochitina macclurei Paris and Al Hajri, 1995

Angochitina macclurei? Paris and Al Hajri, 1995

Angochitina qusaibaensis Paris and Al Hajri, 1995

*Anthochitina jawfensis Al-Hajri and Paris, 1998

Anthochitina primula Nestor, 1994

Anthochitina? sp.

*Armoricochitina armoricana (Rauscher and Doubinger, 1967)

Armoricochitina crassicarinata sp. nov. Paris

Armoricochitina gengi sp. nov. Paris

*Armoricochitina granulifera Nõlvak and Grahn, 1993

*Armoricochitina n. sp. aff. panzuda (Cramer, 1964)

*Armoricochitina nigerica (Bouché, 1965)

Armoricochitina cf. crassicarinata sp. nov. Paris 
Armoricochitina cf. gengi sp. nov. Paris

Armoricochitina? sp.

Belonechitina arabiensis Paris and Al Hajri, 1995

Belonechitina paravitrea Paris and Al Hajri, 1995

Belonechitina pseudarabiensis Butcher, 2009

Bursachitina baqaensis sp. nov. Paris

* Bursachitina bursa (Taugourdeau and de Jekhowsky, 1960)

*Bursachitina concava Eisenack, 1972

*Bursachitina lagenicula Eisenack, 1971

*Bursachitina nana (Nestor, 1994)

*Bursachitina pachygaster (Taugourdeau, 1963)

*Bursachitina timpaniformis Tsegelnjuk, 1982

Bursachitina? sp.

Calpichitina densa (Eisenack, 1962)

*Calpichitina spongiloricata (Wrona, 1980)

*Calpichitina squamosa (Laufeld, 1974)

*Calpichitina velata (Wrona, 1980)

Calpichitina cf. acollaris (Eisenack, 1959)

Calpichitina sp. aff. densa (Eisenack, 1962)

Calpichitina sp.

*Cingulochitina bouniensis Verniers, 1999

*Cingulochitina burdinalensis Verniers, 1999

* Cingulochitina serrata (Taugourdeau and de Jekhowsky, 1960)

*Clathrochitina clathrata Eisenack, 1959

*Clathrochitina sylvanica Jenkins, 1970 
Conochitina alargada Cramer, 1967

*Conochitina campanulaeformis Eisenack 1931

*Conochitina claviformis Eisenack, 1931

Conochitina edjelensis Taugourdeau, 1963

Conochitina elongata Taugourdeau, 1963

* Conochitina fungiformis Eisenack, 1931

*Conochitina incerta Eisenack, 1962

*Conochitina leptostoma Laufeld, 1974

*Conochitina praeproboscifera Nestor, 1994

*Conochitina proboscifera Eisenack, 1937

*Conochitina rara Nestor, 1994

*Conochitina rotundata $\mathrm{sp}$. nov. Paris et al. (this volume)

Conochitina vitrea (Taugourdeau, 1962)

Conochitina viiuae sp. nov. Paris

Conochitina cf. alargada Cramer, 1967

Conochitina cf. edjelensis Taugourdeau, 1963

Conochitina gr. armillata Taugourdeau and de Jekhowsky, 1960

Conochitina sp. aff. vitrea (Taugourdeau, 1962)

Conochitina sp.

Conochitina? sp.

* Conochitina spp.

*Cutichitina legrandi Achab, Asselin and Soufiane, 1993

Cutichitina minivelata sp. nov. Paris

*Cyathochitina campanulaeformis (Eisenack 1931)

Cyathochitina caputoi Da Costa, 1971 
*Cyathochitina kuckersiana (Eisenack, 1934)

*Cyathochitina latipatagium Jenkins, 1969

Cyathochitina neolatipatagium sp. nov. Paris

Cyathochitina cf. caputoi Da Costa, 1971

Cyathochitina gr. caputoi Da Costa, 1971

Cyathochitina sp.

Euconochitina silurica (Taugourdeau, 1963

Euconochitina sp.

*Fungochitina bernesgae (Cramer, 1967)

*Fungochitina hispida (Taugourdeau and de Jekhowsky, 1960)

*Fungochitina illinoisensis Butcher, Mikulic and Kluessendorf, 2010

Fungochitina merrelli sp. nov. Paris

*Fungochitina pilosa (Collinson and Scott, 1958)

Fungochitina? sp. aff. merrelli sp. nov. Paris

Fungochitina? sp.

*Hoegisphaera complanata (Eisenack, 1932)

*Lagenochitina nuayyimensis Paris and Al-Hajri, 1995

* Linochitina ceneratiensis Paris, 1976

* Linochitina cingulata (Eisenack, 1937)

Linochitina? sp.

*Margachitina banwyensis Mullins, 2000

*Margachitina margaritana (Eisenack, 1937)

*? Margachitina leonensis (Cramer, 1964)

Muscochitina olivieri sp. nov. Paris

*Muscochitina muscosa Paris, 1981 
*Muscochitina samiri Boumendjel, 2002

Plectochitina alisawyiahensis sp. nov. Paris

Plectochitina alnaimi sp. nov. Paris

* Plectochitina carminae Cramer, 1964

*Plectochitina clathrospinosa (Eisenack, 1968)

*Plectochitina combazii Cramer, 1967

*Plectochitina concinna Achab, 1978

*Plectochitina fenesdiculae Al-Ameri, 1989

*Plectochitina irregularis Cramer and Diez, 1978

Plectochitina jacquelineae sp. nov. Paris

*Plectochitina jiangsuensis Geng, Grahn and Qian, 1987

Plectochitina longicornis (Taugourdeau and de Jekhowsky, 1960)

*Plectochitina lubnia (Al-Ameri, 1989)

Plectochitina lucasi sp. nov. Paris

*Plectochitina nodosa (Taugourdeau and de Jekhowsky, 1960)

Plectochitina paraguayensis Wood and Miller, 1991

Plectochitina pseudoagglutinans (Taugourdeau, 1963)

*Plectochitina saharica (Taugourdeau, 1962)

*Plectochitina sansalvadorensis (Schweineberg, 1987)

*Plectochitina sylvanica (Jenkins, 1970)

Plectochitina cf. alisawyiahensis sp. nov. Paris

Plectochitina cf. clathrospinosa (Eisenack, 1968)

Plectochitina cf. lucasi sp. nov. Paris

Plectochitina cf. pseudoagglutinans (Taugourdeau, 1963)

Plectochitina sp. aff. alisawyiahensis sp. nov. Paris 
Plectochitina sp. aff. pseudoagglutinans (Taugourdeau, 1963)

Plectochitina sp.

Plectochitina? sp.

Pterochitina deichaii Taugourdeau, 1963

*Pterochitina? perivelata (Eisenack, 1937)

*Sphaerochitina lepta Jenkins 1970

*Sphaerochitina longicollis forma A Paris 1992

*Sphaerochitina longicollis forma B Paris 1992

*Sphaerochitina solitudina Paris, 1988b

*Sphaerochitina sp. indet. Paris, 1991

*Spinachitina bulmani Jansonius, 1964

*Spinachitina cervicornis (Eisenack, 1931)

*Spinachitina fragilis (Nestor, 1980a)

Spinachitina geerti sp. nov, Paris

*Spinachitina imperita (Dicevitchius, 1971)

*Spinachitina maennili (Nestor, 1980b)

*Spinachitina spinosa Van Grootel, 1990 nomen nudum

*Spinachitina taugourdeaui (Eisenack, 1968)

*Spinachitina sp. aff. maennili

Spinachitina cf. geerti sp. nov. Paris

Spinachitina sp.

Tanuchitina obtusa (Taugourdeau and de Jekhowsky, 1960)

\section{Acknowledgements}


The authors thank the Saudi Arabian Ministry of Petroleum and Mineral Resources and the

Saudi Arabian Oil Company (Saudi Aramco) for granting permission to publish this paper.

They also thank very warmly Bernard Owens who initiated the very first steps of this CIMP/Aramco research project.

Olivier Chang Paris prepared the plates and the figures of this paper and organised the repository of the palynological slides and the loading of the relate material in databases. The authors are grateful to the two reviewers, Antony Butcher (Portsmouth University, UK) and Jacques Verniers, (Ghent University, Belgium), for valuable remarks and comments.

\section{REFERENCES}

Achab, A. 1978. Les Chitinozoaires de l'Ordovicien supérieur, Formation de Vauréal et d'Ellis Bay de l'Ile d'Anticosti, Québec. Palinologia (Num. ext.), v. 1, p. 1-19.

Achab, A. 1981. Biostratigraphie par les Chitinozoaires de l'Ordovicien Supérieur-Silurien inférieur de l'Ile de Anticosti. Résultats préliminaires. In J.P. Lespérance (Ed.) Field meeting, Anticosti-Gaspé Québec. II: Stratigraphie et paléontologie. Subcommission on Silurian Statigraphy and Ordovician-Silurian Boundary Working Group, Montréal, p. 143-137.

Achab, A., E. Asselin and A. Soufiane 1993. New morphological characters observed in the order Operculatifera and their implications for the suprageneric chitinozoan classification. Palynology, v. 17, p. 1-9.

Al-Ameri, T.K. 1989. Chitinozoa of the Tanezzuft and Acacus formations, Libya. Iraqi Journal of Sciences, v. 30, p. 203-242.

Al-Hajri, S. 1991. Systematics and biostratigraphy of Middle Ordovician to Lower Silurian chitinozoans of the Arabian Peninsula. MSc thesis, Geosciences, University of 
Pennsylvania, 311 p. (unpublished).

Al-Hajri, S. and F. Paris 1998. Age and palaeoenvironment of the Sharawra Member (Silurian of North-Eastern Saudi Arabia). Geobios, v. 31, p. 3-12.

Aoudeh, S. and S. Al-Hajri 1995. Regional distribution and chronostratigraphy of the Qusaiba Member of the Qalibah Formation in the Nafud Basin, Northwestern Saudi Arabia. The Middle East Petroleum Geosciences, Gulf PetroLink, v. 1, p. 143-154.

Bouché, P.M. 1965. Chitinozoaires du Silurien s.l. du Djado (Sahara nigérien). Revue de micropaléontologie, v. 8, p. 151-164.

Boumendjel, K. 2002. Nouvelles espèces de chitinozoaires du Silurien Supérieur et du Dévonien Inférieur du bassin de Timimoun (Sahara central, Algérie). Review of Palaeobotany and Palynology, v. 118, p. 29-46

Bourahrouh, A. 2002. Chitinozoaires et palynomorphs de l'Ordovicien Supérieur nord gondwanien; impact de la glaciation ashgilienne. Doctoral thesis of Rennes University, 192 p. (unpublished).

Butcher, A., D. 2009. Early Llandovery chitinozoans from Jordan. Palaeontology, v. 52, p. 593-629.

Butcher, A., D. Mikulic and J. Kluessendorf 2010. Late Ordovician-Early Silurian chitinozoans from north-eastern Illinois, USA. Review of Palaeobotany and Palynology, v. 159, p.81-93.

Collinson, C. and A.J. Scott. 1958. Chitinozoan-Faunule of the Devonian Cedar Valley Formation. Illinois State Geological Survey, v. 247, p. 1-34.

Cramer, F.H. 1964. Microplancton from three Palaeozoic formations in the Province of León (NW Spain). Leidse Geologische Mededelingen, v. 30, p. 255-361.

Cramer, F.H. 1967. Chitinozoans of a composite section of Upper Llandoverian to basal Lower Gedinnian sediments in northern Leon, Spain. Bulletin de la Société belge de 
Géologie, v. 75, p. 69-129.

Cramer, F.H. and M.C. Diez 1978. Iberian Chitinozoans. 1. Introduction and summary of PreDevonian data. Palinologia, (Num. ext.), v. 1, p. 149-201.

Da Costa, N.M. 1971. Quitinozoarios silurianos do Igarape da Rainha, Estado do Pará. Departamento Nacional de Produção Mineral. Divicão de Geologia e Mineralogia, Bolletin, v. 255, p. 1-101.

Dicevitchius, E. 1971. Some new species of Chitinozoa from Ordovician and Silurian deposits of the south Baltic and of northwestern Byelorussia. 1. Acanthochitina and some Conochitina. In: Palaeontology and Stratigraphy of Peribaltic and Byelorussia. p. 77-95. Nauka, Moscow (in Russian).

Eisenack, A. 1931. Neue Mikrofossilien des baltischen Silurs I. Paläontologische Zeitschrift, v. 13, p. 74-118.

Eisenack, A. 1932. Neue Mikrofossilien des baltischen Silurs II. Paläontologische Zeitschrift, v. 14 , p. $257-277$.

Eisenack, A. 1934. Neue Mikrofossilien des baltischen Silurs III und neue Mikrofossilien des bohmischen Silurs, I. Paläontologische Zeitschrift, v. 16, p. 52-76.

Eisenack, A. 1937. Neue Mikrofossilien des baltischen Silurs IV. Paläontologische Zeitschrift, v. 19, p. 217-243.

Eisenack, A. 1955a. Chitinozoen, Hystrichosphaeren und andere Mikrofossilien aus dem Beyrichia-Kalk. Senckenbergiana Lethaea, v. 36, p. 157-188.

Eisenack, A. 1955b. Neue Chitinozoen aus dem Silur des Baltikums und dem Devon der Eifel. Senckenbergiana Lethaea, v. 36, p. 311-319.

Eisenack, A. 1959. Neotypen baltischer Silur-Chitinozoen und neue Arten. Neues Jahrbuch für Geologie und Paläontologie, Abhandlungen, v. 108, p. 1-20.

Eisenack, A. 1962. Neotypen baltischer Silur-Chitinozoen und neue Arten. Neues Jahrbuch 
für Geologie und Paläontologie, Abhandlungen, v. 114, p. 291-316.

Eisenack, A. 1968. Microfossilien eines Geschiebes der Borkholmer Stufe, baltisches

Ordovicium, F2. Mitt. Geologisch Staatinstitut Hamburg, v. 37, p. 81-94.

Eisenack, A. 1971. Weitere Mikrofossilien aus dem Beyrichienkalk (Silur). Neues Jahrbuch für Geologie und Paläontologie, Monatshefte, v. 8, p. 449-460.

Eisenack, A. 1972. Chitinozoen und andere Mikrofossilien aus der Bohrung Leba, Pommern. Palaeontographica A, v. 139, p. 64-87.

Geng Liang-Yu, Y. Grahn and Qian Ze-Shu 1987. Llandoverian Chitinozoa from Borehole DI-2 AT Dadua, Xinghua, Jiangsu. Acta Palaeontologica Sinica, v. 26, p. 728-736.

Grahn, Y., and F. Paris 2011. Emergence, biodiversification and extinction of the chitinozoan group. Geological Magazine, v. 148, p. 226-236.

Hill, P.J., F. Paris and J.B. Richardson 1985. Silurian palynomorphs. In B. Thusu, and B. Owens (Eds.), Palynostratigraphy of North-East Libya. Journal of Micropalaeontology, v. 4, p. 27-48.

Jacob, J., F. Paris, O. Monod, M.A. Miller, P. Tang, S.C. George and J-M. Bény 2007. New insights into the chemical composition of the chitinozoans. Organic Geochemistry, v. 38, p. $1782-1788$.

Jansonius, J. 1964. Morphology and classification of some Chitinozoa. Bulletin of Canadian Petroleum Geologists, v. 12, p. 901-918.

Jenkins, W.A.M. 1969. Chitinozoa from the Ordovician Viola and Fernvale Limestones of the Arbuckle Mountains, Oklahoma. Palaeontology, Special Paper, v. 5, p. 1-44.

Jenkins, W.A.M. 1970. Chitinozoa from the Ordovician Sylvan Shale of the Arbuckle Mountains, Oklahoma. Palaeontology, v. 13, p. 261-288.

Laufeld, S. 1974. Silurian Chitinozoa from Gotland. Fossils and Strata, v. 5, p. 1-130.

Loydell, D.K., D. Kaljo and P. Männik 1998. Integrated biostratigraphy of the lower Silurian 
of the Aizpute-41 core, Latvia. Geological Magazine, v. 140, p. 205-229.

Loydell, D.K., P. Männik and V. Nestor 2003. Integrated biostratigraphy of the lower Silurian of the Ohesaare core, Saarema, Estonia. Geological Magazine, v. 135, p. 769-783.

Loydell, D.K., V. Nestor and P. Männik 2010. Integrated biostratigraphy of the lower Silurian of the Kolka-54 core, Latvia. Geological Magazine, v. 147, p. 253-280.

Männil, R. 1971. Distribution of selected Ordovician chitinozoan assemblages and species in northern Europe and their stratigraphical evaluation. Mémoires du Bureau de recherches géologiques et minières, v. 73, p. 309-311.

McClure, H.A. 1988. Chitinozoan and acritarch assemblages, stratigraphy and biogeography of the Early Palaeozoic of Northwest Arabia. Review of Palaeobotany and Palynology, v. 56, p. $41-60$.

Melvin, J. 2014. Lithostratigraphy and depositional history of Upper Ordovician and lowermost Silurian sediments recovered from the Qusaiba-1 shallow core hole, Qasim region, central Saudi Arabia. Review of Palaeobotany and Palynology. (this volume)

Miller, M. and J. Melvin 2005. Significant new biostratigraphic horizons in the Qusaiba Member of the Silurian Qalibah Formation of central Saudi Arabia, and their sedimentological expression in a sequence stratigraphic context. GeoArabia, v. 10, p. 49-92.

Molyneux, S..G. and F. Paris 1985. Late Ordovician palynomorphs. In B. Thusu and B. Owens (Eds.), Palynostratigraphy of Northeast Libya. Journal of Micropalaeontology, v. 4, p. 11-26.

Mullins, G.L. 2000. A chitinozoan morphological lineage and its importance in lower Silurian stratigraphy. Palaeontology, v. 43, p. 359-373.

Mullins, G.L. and D.K. Loydell 2001. Integrated Silurian chitinozoan and graptolite biostratigraphy in the Banwy River section. Palaeontology, v. 44, p. 731-781. 
Nestor, V. 1980a. New Chitinozoan species from the Lower Llandoverian of Estonia. Eesti NSV Teaduste Akadeemia Toimetised, v. 29, p. 98-107.

Nestor, V. 1980b. Middle Llandoverian Chitinozoans from Estonia. Eesti NSV Teaduste Akadeemia Toimetised, v. 29, p. 136-142.

Nestor, V. 1982. New Wenlockian species of Conochitina from Estonia. Proceedings of Estonian Academy of Sciences. Geology, v. 31, p. 105-110.

Nestor, V. 1990. Silurian chitinozoans. In D. Kaljo and H. Nestor (Eds.) Field meeting, Estonia. An Excursion Guidebook. Tallinn, p. 80-83.

Nestor, V. 1994. Early Silurian chitinozoans of Estonia and North Latvia. Academia, v. 4, p. $1-163$.

Nõlvak, J. and Y. Grahn 1993. Ordovician chitinozoan zones from Baltoscandia. Review of Palaeobotany and Palynology, v. 79, p. 245-269.

Paris, F. 1976. Les Chitinozoaires. In H. Lardeux (Ed.). Les Schistes et Calcaires éodévonien de Saint-Céneré (Massif armoricain, France). Mémoire de la Société géologique et minéralogique de Bretagne, v. 19, p. 93-133.

Paris, F. 1978. Apports du microscope électronique à balayage dans l'étude des chitinozoaires opaques. Annales des Mines de Belgique, v. 2, p. 193-202.

Paris, F. 1981. Les chitinozoaires dans le Paléozoïque du sud-ouest de l'Europe (Cadre géologique - Etude systématique - Biostratigraphie). Mémoire de la Société géologique et minéralogique de Bretagne, v. 26, p. 1-496.

Paris, F. 1988a. Late Ordovician and Early Silurian chitinozoans from central and southern Cyrenaica. In A. El Arnauti et al. (Editors.), Subsurface Palynostratigraphy of Northeast Libya. Garyounis University Publication, Benghazi, pp. 61-71.

Paris, F. 1988b. New Chitinozoans from the Late Ordovician - Late Devonian of northeast Libya. In: A. El Arnauti, B. Thusu and B. Owens (Editors), Subsurface 
Palynostratigraphy of Northeast Libya. Garyounis University Publication, Bengazi, pp. 73-87.

Paris, F. 1991. Final report on chitinozoans from well UDAYNAN. 1 (UDYN. 1; 88 samples from cores 17, 18, 19 and 20). Report no. 4 for Saudi Aramco, 29 p., 2 pls. (unpublished).

Paris, F. 1992. Final report on the chitinozoans recorded in well TINAT. 2 (cores 16, 17, 18, 19, 20, 21 and 22). Report no. 7 for Saudi Aramco, 25 p., 2 pls. (unpublished).

Paris, F. 1993. Final report on chitinozoans from well ALISAWYIAH EW-9. Report no. 9 for Saudi Aramco, 17 p., 3 pls. (unpublished).

Paris, F. 2003. Ranges and abundances of early Silurian chitinozoans in Qusaiba-1 shallow core (NE Saudi Arabia). Internal Report for Saudi Aramco, 31 p., 6 pls. (unpublished).

Paris, F. 2005. High resolution biostratigraphy of early Silurian chitinozoans in Baq'a-3 and no. 4 shallow cores (NE Saudi Arabia). Internal Report for Saudi Aramco, 50 p., 12 pls. (unpublished).

Paris, F. 2006. Chitinozoans: a fascinating and mysterious microfossil group. Technical-card and direction for use. Document of Rennes University, p. 1-80 (unpublished).

Paris, F. and S. Al-Hajri 1995. New chitinozoan species from Llandoverian subsurface strata of Saudi Arabia. Revue de micropaléontologie v. 38, p. 311-328.

Paris, F. and J. Nõlvak, 1999. Biological interpretation and paleobiodiversity of a cryptic fossil group: "the chitinozoan animal”. Geobios, v. 32, p. 315-324.

Paris, F., J. Verniers, S. Al-Hajri and H. Al-Tayyar 1995. Biostratigraphy and palaeogeographic affinities of early Silurian chitinozoans from Saudi Arabia. Review of Palaeobotany and Palynology, v. 89, p. 75-90. 
Paris, F., T. Winchester-Seeto, K. Boumendjel, and Y. Grahn 2000. Toward a global biozonation of Devonian chitinozoans. Courrier Forschungsinstitut Senckenberg, v. 220 , p. $39-55$.

Paris, F., M. Miller, S. Al-Hajri' J. Zalasiewicz and M. Williams. 2008. Aeronian and Telychian chitinozoans from Central Saudi Arabia. IPC, Bonn 2008. Abstract, Terra Nostra , p. 215.

Paris, F., Y. Grahn, V. Nestor and A. Lakova 1999. A revised chitinozoan classification. Journal of Paleontology, v. 73, p. 547-568.

Paris, F., B. Thusu, G. Meinhold, J.P. Howard, S. Rasul, D. Strogen, Y. Abutarruma, M. Elgadry and A.G. Whitham 2012. Palynological and palynofacies analysis of early Silurian shales from the shallow borehole CDEG-2a in Dor el Gussa, eastern Murzuq Basin, Libya. Review of Palaeobotany and Palynology, v. 174, p. 1-26.

Paris, F., J. Verniers, M. Miller, S. Al-Hajri' J. Melvin 2014. Late Ordovician- earliest Silurian chitinozoans from the Qusaiba-1 core hole, (North Central Saudi Arabia) and relation to the Hirnantian glaciation. Review of Palaeobotany and Palynology. (this volume)

Rauscher, R. and J. Doubinger 1967. Associations de Chitinozoaires de Normandie et comparaisons avec les faunes déjà décrites. Bulletin du Service de la carte géologiques d'Alsace-Lorraine, v. 20, p. 307-328.

Rickards, B.R, G.A. Booth, F. Paris and A.P. Heward 2010. Marine flooding events of the Early and Middle Ordovician of Oman and the United Arab Emirates and their graptolite, acritarch and chitinozoan associations. GeoArabia, v. 15, p. 81-120.

Schallreuter, R. 1963. Neue Chitinozoen aus ordovizischen Geschieben und Bemerkungen zur Gattung Illichitina. Paläontologische Abhandlungen, v.1, p. 392-405.

Schweineberg, J. 1987. Silurische Chitinozoen aus der Provinz Palencia (Kantabrisches Gebirge, N-Spanien). Gottinger Arbeiten zur Geologie und Paläontologie, v. 33, p. 1- 
94.

Sommer, F.W. and N.M. Van Boekel 1963. Quitinozoários do furo 56, Itaituba, Pará. Anais da Academia Brasileira de Ciênscias, v. 35, p. 571-573.

Taugourdeau, P. 1962. Association de Chitinozoaires dans quelques sondages de la région de Edjelé (Sahara). Revue de micropaléontologie, v. 4, p. 229-236.

Taugourdeau, P. 1963. Etudes de quelques espèces critiques de Chitinozoaires de la région d'Edjelé et compléments à la faune locale. Revue de micropaléontologie, v. 6, p. 130144.

Taugourdeau, P. 1966. Les Chitinozoaires, techniques d'études, morphologie et classification. Mémoire de la Société Géologique de France, nouvelle série, v. 45, p. 1-64.

Taugourdeau, P. and B. de Jekhowsky 1960. Répartition et description des Chitinozoaires siluro-dévoniens de quelques sondages de la C.R.E.P.S., de la C.F.P.A. et de la S.N. Repal au Sahara. Revue de l’Institut Français du Pétrole, v. 15, p. 1199-1260.

Tsegelnjuk, P.D. 1982. Silurian Chitinozoa from Podolia. Naukova Dumka, Kiev. 160 p. (in Russian).

Van Grootel, G. 1990. Litho- en Biostratigrafische studie met Chitinozoa in het westelijk deel van het Massief van Brabant. Thesis of Ghent University (unpublished).

Verniers, J. 1999. Calibration of Chitinozoa versus graptolite biozonation in the Wenlock of Built Wells district (Wales, U. K.), compared with other areas in Avalonia and Baltica Bollettino della Societa Paleontologica Italiana, v. 38, p. 359-380.

Verniers, J., V. Nestor, F. Paris, P. Dufka, S. Sutherland and G. Van Grootel 1995. A global Chitinozoa biozonation for the Silurian. Geological Magazine, v. 132, p. 651-666.

Wilson, L.R. and R.W. Hedlund 1964. Calpichitina scabiosa, a new Chitinozoan from the Sylvan Shale (Ordovician) of Oklahoma. Oklahoma Geological Notes, v. 24, p. 161-164. Wood, G.D. and M.A. Miller 1991. Distinctive Silurian chitinozoans from the Itacurubí 
Group (Vargas Peña Shale), Chaco Basin, Paraguay. Palynology, v. 15, p. 181-192.

Wrona, R. 1980. Upper Silurian - Lower Devonian Chitinozoa from the subsurface of southeastern Poland. Palaeontologia Polonica, v. 41, p. 103-165.

Zalasiewicz, J., M. Williams, M. Miller, A. Page and E. Blackett 2007. Early Silurian (Llandovery) graptolites from Central Saudi Arabia: first documented record of Telychian faunas from the Arabian Peninsula. GeoArabia, v. 12, p. 15-36.

Zalasiewicz, J.A., L. Taylor, A.W.A. Rushton, D.K. Loydell, R.B. Rickards and M. Williams 2009. Graptolites in British stratigraphy. Geological Magazine, v. 146, p. 785-850. 
Captions of tables 1-3 and 19-22 (N. B. Captions of Tables 4 to 18 are already

introduced in the text)

Note to the editor: in order to fulfil the requests of the chief editor, tables 1-3 are removed from the main text and introduced in Appendix A. Because the lettering was too small in the stratabug diagrams, they are replaced by classical palynological diagrams (Figs. 6-8) and the corresponding staratbug diagrams are transferred in a new Appendix $C$ as Table 19 to Table 21. As a consequence, the former "Table 19" is transferred in a new Appendix D as Table 22.

Table 1. Data concerning the lithology, the processing, and the faunal content of the core samples processed in the Silurian part of the Qusaiba-1 core hole.

Table 2. Data concerning the lithology, the processing, and the faunal content of the core samples processed in the Baq'a-4 core hole.

Table 3. Data concerning the lithology, the processing, and the faunal content of the core samples processed in the Baq'a-3 core hole.

Table 19. Chitinozoans of the early Rhuddanian and mid-Aeronian samples from the Qusaiba Member of the Qusaiba-1 core hole plotted on a stratabug diagram. The author(s) and the year of publication of the recorded chitinozoans taxa are given on Table 22.

Table 20. Chitinozoans of the mid-Aeronian and early Telychian samples from the Qusaiba Member of the Baq'a-4 core hole plotted on a stratabug diagram. The author(s) and the year of publication of the recorded chitinozoans taxa are given on Table 22. 
Table 21. Chitinozoans of the Telychian samples from the Qusaiba Member of the Baq'a-3 core hole plotted on a stratabug diagram. The author(s) and the year of publication of the recorded chitinozoans taxa are given on Table 22.

Table 22. List of the chitinozoan taxa recorded in the Qusaiba-1, Baq'a-3 and Baq'a-4 core holes. The chitinozoan species cited in the text but not present in the studied material have an asterisk.

\section{Captions of the figures}

Figs. 1a-c. Location map showing the study areas in Saudi Arabia (1a) and the position of the previously studied wells. (1b) location of the Qusaiba-1 core hole, (1c) location of the Baq'a-3 and Baq'a-4 core holes (modified from Zalasiewicz et al., 2007).

Fig. 2. Lithostratigraphy, and Early Palaeozoic stratigraphic nomenclature in Saudi Arabia (modified from Miller and Melvin, 2005; Melvin, this volume). (generalized lithology: sand dominated in yellow; shale dominated in brown).

Fig. 3. Lithological column and location of the studied core samples in the early Silurian Qusaiba Member of the Qalibah Formation in the Qusaiba-1 core hole. (lithology: sand dominated in yellow; shale dominated in brown).

Fig. 4. Location of the studied core samples in the early Silurian Qusaiba Member of the 
Qalibah Formation in the Baq'a-4 core hole. (lithology: shale dominated in brown).

Fig. 5. Location of the studied core samples in the early Silurian Qusaiba Member of the Qalibah Formation in the Baq'a-3 core hole. (lithology: shale dominated in brown).

Fig. 6. Biozonation, ranges and abundances of the chitinozoans recorded in the early Rhuddanian and in the mid-Aeronian samples from the Qusaiba Member of the Qusaiba-1 core hole. The author(s) and the year of publication of the recorded chitinozoans taxa are given on Table 22.

Fig. 7. Biozonation, ranges and abundances of the chitinozoans recorded in the mid-Aeronian and early Telychian samples from the Qusaiba Member of the Baq'a-4 core hole. The author(s) and the year of publication of the recorded chitinozoans taxa are given on Table 22.

Fig. 8. Biozonation, ranges and abundances of the chitinozoans recorded in the Telychian samples from the Qusaiba Member of the Baq'a-3 core hole. The author(s) and the year of publication of the recorded chitinozoans taxa are given on Table 22.

Fig. 9. Chitinozoan biozones and subbiozones identified in the Qusaiba-1, Baq'a-4 and Baq'a3 core holes. Correlation with the ISWH EW-9, and age assignments with regard to the early Silurian graptolite zonation (Zalasiewicz et al., 2007, 2009) and to the standard Silurian chronostratigraphy with the same colour code as in Figures 6-8. 
Figs. 10a-b. Cross plots of the measurements of Conochitina viiuae sp. nov. Paris from the Qusaiba-1 core hole, core 26, at $245.8 \mathrm{ft} .10 \mathrm{a}$ : the chamber diameter (Dp) plotted against the vesicle length (L); 10b: the chamber diameter (Dp) plotted against the neck diameter (Dc). The compression affecting the diameter of the chamber and of the neck is not corrected for. (Holotype: red diamond).

Figs. 11a-b. Cross plots of the measurements of Spinachitina geerti sp. nov. Paris from the Ba'qa-4 core hole, core 28 , at $240.7 \mathrm{ft} .11 \mathrm{a}$ : the chamber diameter (Dp) plotted against the vesicle length $(\mathrm{L})$; 11b: vesicle length $(\mathrm{L})$ plotted against the chamber length $(\mathrm{lp})$. The compression affecting the chamber diameter is not corrected (Holotype: red diamond).

Fig. 12. Cross plots of the measurements of Cyathochitina neolatipatagium sp. nov. Paris from the Qusaiba-1 core hole, core 14, $136.5 \mathrm{ft}$ and $133.35 \mathrm{ft}$. The chamber diameter (Dp) is plotted against the carina width (1 carina). (Holotype: red diamond).

Figs. 13a-b. Cross plots of the measurements of Ancyrochitina alhajrii sp. nov. Paris from the Baq'a-3 core hole, core 47, at $441.7 \mathrm{ft} .13 \mathrm{a}$ : vesicle length (L) plotted against the neck length (lc); 13b: the chamber diameter (Dp) plotted against the vesicle length (L). (Holotype: red diamond).

Figs. 14a-b. Cross plots of the measurements of Ancyrochitina camilleae sp. nov. Paris from the Baq'a-4, core 19, at $163.0 \mathrm{ft} .11 \mathrm{a}$ : vesicle length (L) plotted against the chamber diameter (Dp); 11b: the processes length (1 proc.) plotted against the vesicle length $(\mathrm{L})$. (Holotype: red diamond). 
Figs. 15a-b. Cross plots of the measurements of Plectochitina alisawyiahensis sp. nov. Paris from the Ba'qa-3 core hole, core 40 at $370.4 \mathrm{ft}$, and core 49 at $450.1 \mathrm{ft} .15 \mathrm{a}$ : vesicle length (L) plotted against the neck length (lc); 15b: the processes length (1 proc.) plotted against the vesicle length (L). (Holotype: red diamond).

Figs. 16a-b. Cross plots of the measurements of Plectochitina alnaimi sp. nov. Paris from the Qusaiba-1 core hole, core 14 at 140.1 ft. 16a: vesicle length (L) plotted against the chamber diameter (Dp); 16b: the neck length (lc) plotted against the vesicle length (L). (Holotype: red diamond).

Figs. 17a-b. Cross plots of the measurements of Plectochitina jacquelineae sp. nov. Paris from the Baq'a-3 core hole, core 34 at $306.0 \mathrm{ft}$. 17a: vesicle length (L) plotted against the neck length (lc); 17b: the chamber diameter (Dp) plotted against the vesicle length (L). (Holotype: red diamond).

Figs. 18a-b. Cross plots of the measurements of Plectochitina lucasi sp. nov. Paris from the Baq'a-3 core hole, core 30 at $271.8 \mathrm{ft}$ depth. 18a: vesicle length (L) plotted against the chamber diameter (Dp); 18b: the neck length (lc) plotted against the vesicle length (L). (Holotype: red diamond).

Figs. 19a-b. Cross plots of the measurements of Fungochitina merrelli sp. nov. Paris from the Baq'a-3 core hole, at $450.1 \mathrm{ft}$ depth, and 9 specimens from the Baq'a-4 core hole core at 120.1 and $40.1 \mathrm{ft}$ depth. 19a: vesicle length (L) plotted against the chamber diameter 
(Dp); 19b: the neck length (lc) plotted against the vesicle length (L). (Holotype: red diamond).

Figs. 20a-b. Cross plots of the measurements of Muscochitina olivieri sp. nov. Paris from the Baq'a-3, core 27, sample from $251.1 \mathrm{ft}$. 20a: vesicle length (L) plotted against the chamber diameter (Dp); 20b: the neck length (lc) plotted against the vesicle length (L). (Holotype: red diamond).

Figs. 21a-b. Cross plots of the measurements of Bursachitina baqaensis sp. nov. Paris from the Baq'a-4, core 19, sample from $163.0 \mathrm{ft}$. 21a: vesicle length (L) plotted against the chamber diameter $(\mathrm{Dp}) ; 21 \mathrm{~b}$ : the chamber diameter (Dp) plotted against the chamber length (lp). (Holotype: red diamond).

Figs. 22a-b. Cross plots of the measurements of Cutichitina minivelata sp. nov. Paris from the Baq'a-3, core 24, sample from $228.8 \mathrm{ft}$ and core 14 at $136.5 \mathrm{ft} .22 \mathrm{a}$ : vesicle length (L) plotted against the chamber diameter (Dp); 22b: vesicle length (L) plotted against the chamber diameter (Dp) in a one chain-like structure. (Holotype: red diamond).

Figs. 23a-b. Cross plots of the measurements of Armoricochitina crassicarinata sp. nov. Paris from t the Baq'a-3, core 40, sample from $370.4 \mathrm{ft}$. 23a: vesicle length (L) plotted against the chamber diameter (Dp); 23b: the collarette/neck length (lcoll.) plotted against the vesicle length (L). (Holotype: red diamond).

Figs. 24a-b. Cross plots of the measurements of Armoricochitina gengi sp. nov. Paris from the Baq'a-3, core 27, sample from $250.5 \mathrm{ft}$. 24a: vesicle length (L) plotted against the 
chamber diameter (Dp); 24b: the vesicle length (L) plotted against the neck/collarette length (lcoll.). (Holotype: red diamond).

\section{Plate captions}

Plate I. Mid-Aeronian chitinozoans (upper qusaibaensis Biozone) from the Qusaiba-1 core hole. Scale bar represents 100 micrometers, except for 1b, 3b, 4b, 4c, 5b, 6b and 8 (10 micrometers).

1, 4, 6. Muscochitina olivieri sp. nov. 251.10 ft. (1): paratype, IGR 72253, (M44/1). (4): holotype, IGR 72253, (O49). (1b, 4b-c): note the very peculiar ornamentation composed of finial structures with thin filaments connecting the tips of granuleshaped pillars. (6): IGR 72253 (Q44/2). This specimen is assigned to Muscochitina olivieri sp. nov. in spite the thin filaments connecting granule-shaped pillars are eroded.

2. Conochitina viiuae sp. nov. $251.10 \mathrm{ft}$; IGR 72253 (M44). In this totally compressed vesicle, the tilted chamber bottom hides the mucron.

3, 9. Conochitina elongata Taugourdeau, 1963. 251.10 ft. (3a): IGR 72253 (M47/1). Note the thickened rim corresponding to the margin. (9): IGR 72253 (O45).

5. Angochitina qusaibaensis Paris and Al-Hajri, 1995. 251.10 ft; IGR 72253 (Q44). Possibly a new form with a long slender neck acting as a transitional form between A. qusaibaensis and "true" A. hemeri. The prosome of these specimens is prolonged by a thin walled tubular structure (see also Plate II, 6-9). 
7. Plectochitina pseudoagglutinans (Taugourdeau, 1963). $251.10 \mathrm{ft}$; IGR 72253 (P46/4).

8. Conochitina edjelensis Taugourdeau, 1963. 251.10 ft; IGR 72253 (O45/2).

Plate II. Mid-Aeronian chitinozoans (upper quasibaensis Biozone) from the Qusaiba-1 core. Scale bar represents 100 micrometers, except for $3 b, 4 b, 6 b$ and 9 (10 micrometers).

1-2. Cyathochitina caputoi Da Costa, 1971. 245.80 ft. (1): IGR 72256 (P43). (2): IGR $72256(\mathrm{R} 43 / 4)$.

3. Pterochitina deichaii Taugourdeau, 1963. 245.80 ft; IGR 72256 (Q43). Detail of a catenary structure showing the modification of the general shape of the vesicle after compression. Note the peculiar operculum with radial "ribs" around the central circular scar corresponding to the inter-vesicle connection.

4-5. Conochitina viiuae sp. nov. $245.80 \mathrm{ft}$. (4): paratype, IGR 72256 (O44/3), note the elongate vesicle with a constriction, and (4b) the protruding mucron. (5) holotype, IGR 72256 (M44/4).

6-9. Angochitina qusaibaensis Paris and Al-Hajri, 1995. These represent possibly a new long and slender-necked transitional form between typical A. qusaibaensis and A. hemeri. 245.80 ft. (6): IGR 72256 (P47/4). (7): IGR 72256 (P47/4). (8): IGR 72256 (R48). (9): IGR 72256 (R47/4). The prosome of these specimens is extended by an extruded thin-walled tubular structure at least as long as the vesicle itself. $(6 b, 9)$ : close-up of the lips surrounding this structure.

10. Plectochitina cf. P. alnaimi sp. nov. 245.80 ft; IGR 72256 (R47) (lost specimen). Note the serrate aperture. 
Plate III. Mid-Aeronian chitinozoans (alargada Biozone) from the Qusaiba-1 core hole.

Scale bar represents 100 micrometers, except for $2 b, 3 b, 4 b, 10 b$ and 11 (10 micrometers).

1-2. Conochitina sp. 210.90 ft. (1): IGR 72270 (P46). (2a): IGR 72270 (Q47/1). (2b): detail of the mucron with a central pit.

3. Belonechitina paravitrea Paris and Al-Hajri, 1995. $210.90 \mathrm{ft}$; IGR 72270 (O43/2).

4. Fungochitina ? sp. aff. F. merrelli sp. nov. 210.90 ft. (4): IGR 72270 (N42/2); (4b): note the crown of simple to bi-rooted, very short processes around the margin.

5. Calpichitina sp. aff. densa (Eisenack, 1962). 210.90 ft; IGR 72270 (O44/1). Catenary structure with the operculum of one vesicle still fixed to the apex of the neighbouring vesicle.

6. Plectochitina alnaimi sp. nov. $210.90 \mathrm{ft}$, IGR $72270(\mathrm{Q} 42 / 3)$.

7-8. Plectochitina pseudoagglutinans (Taugourdeau, 1963). (7): 210.90 ft IGR 72270 (S42/1). (8): $228.80 \mathrm{ft} ;$ IGR 72264 (P43/3).

9. Cutichitina minivelata sp. nov. $228.80 \mathrm{ft}$; IGR 72264 (S46/1). The holotype is the second vesicle (note the tilted disc-like operculum); the paratypes are the seven other vesicles of the chain-like structure.

10. Angochitina qusaibaensis? Paris and Al-Hajri, 1995. $228.80 \mathrm{ft}$; IGR 72264 (R48/3). (10a) This puzzling specimen shares some characters with A. hemeri and A. macclurei. (10b) Note the progressive change from a granular ornamentation on the flanks to a more spiny ornamentation near the margin. 
11. Pterochitina deichaii Taugourdeau, 1963. 228.80 ft; IGR 72270 (S48). Three dimensional vesicle with the carina near the equator of the chamber and the small disc-like operculum.

Plate IV. Mid-Aeronian chitinozoans (hemeri Biozone) from the Qusaiba-1 core hole.

Scale bar represents 100 micrometers, except for $5 \mathrm{~b}$ (10 micrometers).

1. Cyathochitina caputoi Da Costa, 1971. $167.70 \mathrm{ft}$; IGR 722782 (P38/2); (1a): note the short carina with rounded borders.

2-4. Conochitina gr. armillata Taugourdeau and de Jekhowsky, 1960. (2a): 167.70 ft; IGR 722782 (N40), note the three connected vesicles, the widened chamber of the species, and the mucron. (3): $167.70 \mathrm{ft}$ IGR 722782 (P43/1). (4): $176.05 \mathrm{ft}$; IGR $72279(\mathrm{R} 45 / 3)$.

5-6. Angochitina hemeri Paris and Al-Hajri, 1995. 176.05 ft. (5a): IGR 72279 (T46/2). (5b): note the well-developed spines on the chamber. (6): IGR 72279 (Q46/4).

7-8. Plectochitina paraguayensis Wood and Miller, 1991. 176.05 ft. (7): IGR 72279 (Q49/4). (8): IGR 72279 (S49), note the very long processes (close to 250 micrometers length).

9. Plectochitina alnaimi sp. nov. 176.05 ft; IGR 72279 (R47).

Plate V. Aeronian chitinozoans (hemeri Biozone) from the Qusaiba-1 core hole. Scale bar represents 100 micrometers, except for $2-3,6,8 \mathrm{~b}$ and $13 \mathrm{~b}$ (10 micrometers). 
1. Angochitina hemeri Paris and Al-Hajri, 1995. 140.10 ft; IGR 72291 (N42). Very elongate specimen with eroded ornamentation (spines preserved only in a fold of the chamber).

2, 10. Plectochitina alnaimi sp. nov. (2): holotype, $140.10 \mathrm{ft}$; IGR 72291 (Q42); note the "lambda-type" processes. (10):paratype, core sample from $150.80 \mathrm{ft}$; ; IGR 72286 (R44).

3, 11-12. Anthochitina primula Nestor, 1994. 145.90 ft. (3): IGR 72288, close up showing the serrate membranous rim located along the margin. (11): IGR 72288 (P42), well-developed membranous serrate rim around the margin. (12): IGR 72288 (O43), partly compressed specimen with a tilted bottom.

4. $\quad$ Fungochitina? sp. aff. F. merrelli sp. nov. 145.90 ft, IGR 72288 (O42/4), antiapertural view showing short spines on the chamber bottom.

5, 9. Plectochitina paraguayensis Wood and Miller, 1991. (5): $145.90 \mathrm{ft}$.; IGR 72288 (S45): long processes possibly connected at their distal end. (9): core sample from 150.80 ft; IGR 72286 (P43/4).

6. Plectochitina cf. clathrospinosa (Eisenack, 1968). $145.90 \mathrm{ft}$; IGR 72288 (Q47), specimen with a tilted bottom showing the peculiar rooting pattern of the processes.

7. Conochitina gr. armillata Taugourdeau and de Jekhowsky, 1960. 145.90 ft; IGR 72288 (N44). Note the presence of a mucron, and the inverted orientation of these stuck vesicles.

8. $\quad$ Fungochitina ? sp. aff. F. merrelli sp. nov. 145.90 ft; IGR 72288 (R44/2). (8a) Note the densely distributed well-developed spines on the chamber, and the longer spines (often of "lambda-type") surrounding the margin (8b). 
13. Belonechitina paravitrea Paris and Al-Hajri, 1995. 150.80 ft; IGR 72286 (P41/2).

(13a) Note the thinness of the wall, and the random and scarce minute spines concentrated close to the margin (13b).

Plate VI. Aeronian chitinozoans (hemeri Biozone) from the Qusaiba-1 core hole. Scale bar represents 100 micrometers, except for $3 \mathrm{~b}$ and 5 (10 micrometers).

1-2. Linochitina ? sp. 132.05 ft. (1): IGR 72299 (N44/3). (2): IGR 72299 (O43). These connected specimens show vesicle outline and a connection pattern identical to those of Linochitina Eisenack, 1968 emend Paris, 1981. Because the tubular copula has not been seen, these specimens could also belong to Euconochitina. They are therefore provisionally kept in open nomenclature.

3. Angochitina hemeri Paris and Al-Hajri, 1995. 132.05 ft. (3a): IGR 72299 (S43/2). (3b): note the partially eroded spines on the chamber similar to the ornamentation of A. qusaibaensis Paris and Al-Hajri, 1995.

4-5. Belonechitina arabiensis Paris and Al-Hajri, 1995. 133.45 ft. (4): IGR 72298 (P50/3). (5): IGR 72298 (P50/1), specimen with unusually densely and welldeveloped spines (possibly a different species).

6. Plectochitina sp. 132.05 ft; IGR 72299 (S45/2). Note long cell-like processes with simple branching at their half length.

7-8, 11. Cyathochitina neolatipatagium sp. nov. (7): paratype, $133.45 \mathrm{ft}$; IGR 72298 (Q50). (8): holotype, 136.50 ft; IGR 72293 (Q40/4). (11): paratype, IGR 72293 (Q40). Note the thickened rim around the margin, and the large carina.

9. Ancyrochitina gr. ancyrea (Eisenack 1931. 134.20 ft; IGR 72296 (P44/4). 
10. Calpichitina sp. aff. densa (Eisenack, 1962). 134.20 ft; IGR 72296 (N46/4). Folded and compressed chain-like structure. The large disc-like operculum surrounded by a short lip is visible on the second vesicle on the right side.

12. Cutichitina minivelata sp. nov. 136.50 ft; IGR 72293 (N40). (12a): compressed catenary structure showing a morphological differentiation in the curved part of the chain (poorly separated and smaller vesicles). (12b): close up of the upper part of the chain showing the spongy outer layer "extruded" laterally during the lateral compression of the chain-like structure.

Plate VII. Aeronian and early Telychian chitinozoans (hemeri and macclurei biozones) from the Baq'a-4 core hole. Scale bar represents 100 micrometers, except for 3b, $7 \mathrm{~b}$ and 8 (10 micrometers).

1, 4-5, 7-8. Spinachitina geerti sp. nov. Core 28, sample from $240.7 \mathrm{ft}$. Note the large range in vesicle silhouette, and the short spines randomly distributed on the chamber. (1): paratype, IGR 72371 (Q42/1). (4): paratype, IGR 72371 (Q41/2). (5): atypical specimen with a very short sub-conical vesicle, IGR 72371 (O42/2). (7a): holotype, IGR 72371 (P42/4) and detail of the spines on its margin (7b). (8): paratype, IGR 72371 (Q41), detail of the long spines on the margin.

2-3. Angochitina macclurei Paris and Al-Hajri, 1995. (2) core 7, sample from $40.1 \mathrm{ft}$; IGR $72351(\mathrm{~N} 44 / 3)$. The specimen is shorter than typical A. macclurei but the short spines are present on the chamber and on the neck. (3a): core 28, sample from $240.7 \mathrm{ft}$, IGR 72371 (P39/2). (3b): note the short spines on the chamber and on the neck.

6. Plectochitina pseudoagglutinans (Taugourdeau, 1963). Core 7, sample from $40.1 \mathrm{ft}$; 
IGR 72351 (O47/1). Note long processes and the blunt spines on the chamber and on the neck.

Plate VIII. Aeronian and early Telychian chitinozoans (hemeri and macclurei biozones) from the Baq'a-4 core hole. Scale bar represents 100 micrometers, except for $2 \mathrm{~b}$ (10 micrometers).

1, 6. Ancyrochitina camilleae sp. nov. Core 19, sample from $163.0 \mathrm{ft}$. Note the short vesicle and the long and slender processes branching several times distally. (1): holotype, IGR 72364 (P41/4). (6): paratype, IGR 72364 (P44).

2. Spinachitina cf. geerti sp. nov. Core 19, sample from 163.0 ft; IGR 72364 (N43). Note the short blunt spines densely distributed along the margin. (2b): minute tubercles occur on the lower part of the chamber (eroded spines?).

3. Bursachitina baqaensis sp. nov. Core 19, sample from $163.0 \mathrm{ft}$ IGR 72364 (O46/1). Twins showing the sharp margin; the upper vesicle is the holotype, and the lower a paratype.

4. Conochitina cf. alargada Cramer, 1967. Core 19, sample from 163.0 ft; IGR 72364 (N44/4).

5, 8. Belonechitina paravitrea Paris and Al-Hajri, 1995. Core 19, sample from 163.0 ft. (5): IGR 72364 (N45/4). (8): IGR 72364 (N44), specimen shorter than the type material.

7. Calpichitina densa (Eisenack, 1962). Core 7, sample from $40.7 \mathrm{ft}$; IGR 72351 (M45/3).

Plate IX. Early Telychian chitinozoans (macclurei Biozone) from the Baq'a-3 core hole. Scale bar represents 100 micrometers, except for $2 b$ and 7 (10 micrometers). 
1, 3. Fungochitina merrelli sp. nov. Core 49, sample from 450.1 ft. (1): holotype, IGR 72340 (R45), densely distributed spiny ornamentation extending on the neck. (3): paratype, IGR 72340 (S45/3); "lambda-based" spines on the chamber and on the neck; the spines around the margin are probably partly destroyed.

2. Angochitina macclurei Paris and Al-Hajri, 1995. Core 49, sample from $450.1 \mathrm{ft}$. (2a): IGR 72340 (U44). (2b): close up of the spiny ornamentation with cones ended by a slender spine.

4, 6. Plectochitina alisawyiahensis sp. nov. Core 49, sample from $450.1 \mathrm{ft}$. (4): IGR 72340 (P43), specimen with few processes connected at their distal end with a rim. (6): IGR 72340 (T43/2), specimen in lateral view showing the racket-like arrangement of the sets of processes.

5. Pterochitina deichaii Taugourdeau, 1963. Core 49, sample from $450.1 \mathrm{ft}$; IGR 72340 (O43/4). Chain compressed perpendicular to the vesicle equator.

7. Plectochitina alisawyiahensis sp. nov. Core 49, sample from $450.1 \mathrm{ft}$; IGR 72340 (R41). Close up of the random spines on the flexure.

Plate X. Early Telychian chitinozoans (macclurei Biozone) from the Baq'a-3 core hole. Scale bar represents 100 micrometers, except for $2 \mathrm{~b}, 3 \mathrm{a}-\mathrm{b}, 4 \mathrm{~b}$ and $5 \mathrm{~b}$ (10 micrometers).

1. Angochitina macclurei Paris and Al-Hajri, 1995. Core 47, sample from $431.7 \mathrm{ft}$; IGR 72339 (Q45/3), cluster of compressed individuals with a fairly short neck.

2, 4. Ancyrochitina alhajrii sp. nov. Core 47, sample from 431.7 ft. (2a): paratype, IGR 72339 (O40) with minute spines on the wall (2b). (4a): holotype, IGR 72339 (O45), 
note the long processes, and the minute spines (length is less than 10 micrometers and their diameter less than 1 micrometer) randomly distributed on the chamber and on the base of the neck (4b).

3. Angochitina macclurei Paris and Al-Hajri, 1995. Core 47, sample from 431.7 ft. (3a):

IGR 72339 (M43/2), three-dimensional vesicle showing the original spherical chamber. (3b): detail of the short thickset spines.

5. Fungochitina merrelli sp. nov. Core 49, sample from $450.1 \mathrm{ft}$. (5a): paratype, IGR 72340 (Q45/4); note the slender spines on the chamber; (5b): spines with lambda proximal ends and exceeding 10 micrometers length.

Plate XI. Early Telychian chitinozoans (macclurei Biozone) from the Baq'a-3 core hole. Scale bar represents 100 micrometers, except for $1 \mathrm{~b}$ and $2 \mathrm{~b}$ (10 micrometers).

1. Angochitina macclurei Paris and Al-Hajri, 1995. (1a) Core 42, sample from $388.0 \mathrm{ft}$; IGR 72335 (N46/4), short form; (1b): detail of the short conical spines.

2. Armoricochitina crassicarinata sp. nov. Core 40, sample from $370.4 \mathrm{ft}$. (2a): IGR 72332 (N44/4), distorted specimen with an unusually wide margin. (2b): detail of the slightly wrinkled surface and of the thick, but short, carina looking like a rim on the margin.

3. Plectochitina paraguayensis Wood and Miller, 1991. Core 42, sample from $388.0 \mathrm{ft}$; IGR 72335 (Q50).

4. $\quad$ Plectochitina alisawyiahensis sp. nov. (4) Core 42, sample from $388.0 \mathrm{ft}$; IGR 72335 $(\mathrm{O} 48 / 3)$. Note the blunt spines on the neck.

5. Plectochitina sp. aff. alisawyiahensis sp. nov. Core 42, sample from 388.0 ft; IGR 
72335 (R50/2). Note the bi-rooted processes and their branching distally.

6. Ancyrochitina alhajrii sp. nov. Core 47, sample from $431.7 \mathrm{ft}$; IGR 72339 (L43/4), the apparent branching of one of the processes is an artifact (organic fragment stuck on it).

7. Transitional form between Plectochitina longicornis (Taugourdeau and de Jekhowsky, 1960) and Plectochitina paraguayensis Wood and Miller, 1991. Core 42, sample from $388.0 \mathrm{ft}$; IGR 72335 (P48/1). This specimen has broad processes, recalling those of $P$. paraguayensis. The latter species, except its holotype, has a shorter neck and a more ovoid chamber.

Plate XII. Early Telychian chitinozoans (macclurei Biozone) from the Baq'a-3 core hole.

Scale bar represents 100 micrometers, except for $5 b$ and $7 b$ (10 micrometers).

1. Ancyrochitina aculeata Taugourdeau and de Jekhowsky, 1960. Core 38, sample from $350.1 \mathrm{ft}$; IGR 72329 (O48/1), granules on the chamber (scars of spines?) and the larger spines on the neck.

2, 6. Armoricochitina crassicarinata sp. nov. Core 40, sample from 370.4 ft. (2): holotype, IGR 72332 (S48/1), finely wrinkled chamber surface (micro-corrugations) and thickened rim below the margin; (6): paratype, IGR 72332 (Q48/2), twins showing the type of inter-vesicle linkage.

3. Plectochitina cf. alisawyiahensis sp. nov. Core 40, sample from 370.4 ft; IGR 72332 (Q47).

4-5. Angochitina macclurei Paris and Al-Hajri, 1995. (4): core 40, sample from $370.4 \mathrm{ft}$, typical specimens with a spherical chamber and a neck length close to / or exceeding 3 times the chamber length, IGR 72332 (P49). (5a): core 40, sample from $370.4 \mathrm{ft}$, IGR 
72332 (O44); (5b): typical spines on the chamber (hemispherical to ovoid base extending into a thin spine).

7. Plectochitina alisawyiahensis sp. nov. Core 40, sample from 370.4 ft; IGR 72332 (P44/3). Holotype, note the "eye" (ring-structure) at mid-length of some processes, and the distal linkage of the processes with a rim.

8. $\quad$ Calpichitina densa (Eisenack 1962). Core 40, sample from $370.4 \mathrm{ft}$; IGR 72332 (R46). (8a): these specimens arranged in chain-like structure show folding of the outer layer of their operculum $(8 b)$ in relation with the flattening of the vesicles. This form seems to announce the first appearance of the genus Margachitina (i.e., M. banwyensis Mullins, 2000).

Plate XIII. Early Telychian chitinozoans (macclurei and obtusa biozones) from the Baq'a-3 core hole. Scale bar represents 100 micrometers, except for $4 b, 6 b$ and $7 b$ (10 micrometers).

1. Angochitina macclurei Paris and Al-Hajri, 1995. Core 38, sample from $350.1 \mathrm{ft}$; IGR 72329 (N46); typical specimen (spherical chamber and a neck length close to 3 times the chamber length).

2. Armoricochitina ? sp. Core 38, sample from $350.1 \mathrm{ft}$; IGR 72329 (P46/1). These connected very short vesicles are possibly teratologic individuals of $A$. gengi sp. nov. or the very first representative of the genus Cingulochitina.

3. Calpichitina densa (Eisenack, 1962). Core 38, sample from $350.1 \mathrm{ft}$; IGR 72329 (R47/3).

4-5. Tanuchitina obtusa (Taugourdeau and de Jekhowsky, 1960). Core 38, sample from $350.1 \mathrm{ft}$. (4a): IGR 72329 (R47); (4b): detail of the carina. (5): IGR 72329 (M48/4). 
6. $\quad$ Cutichitina cf. minivelata sp. nov. (6a) core 38, sample from $350.1 \mathrm{ft}$. IGR 72329 $(\mathrm{O} 48 / 3) ;(6 \mathrm{~b})$ : the spongy outer layer is still partly stuck on the chamber of this questionable specimen compressed along the vesicle axis.

7. Armoricochitina cf. crassicarinata sp. nov. Core 38, sample from $350.1 \mathrm{ft}$; IGR 72329 (Q47). This elongate specimen separates from the other representatives of the species by its flexure and by a better-developed neck/collarette. (7b): close up of the microcorrugations and of the carina.

8. Ancyrochitina aculeata Taugourdeau and de Jekhowsky, 1960. Core 38, sample from $350.1 \mathrm{ft}$; IGR 72329 (Q49); large spines on the neck and on the upper part of the chamber.

Plate XIV. Early Telychian chitinozoans (macclurei and obtusa biozones) from the Baq'a-3 core hole. Scale bar represents 100 micrometers, except for $1 \mathrm{~b}, 4 \mathrm{~b}$, and $6 \mathrm{~b}$ (10 micrometers).

1, 5. Angochitina macclurei Paris and Al Hajri, 1995. Core 34, sample at $306.0 \mathrm{ft}$; (1a): IGR 72323 (N45). (5): IGR 72323 (O45/3), short specimen.

2. Ancyrochitina aculeata Taugourdeau and de Jekhowsky, 1960. Core 34, sample at $306.0 \mathrm{ft}$; IGR 72323 (R43). Atypical specimen with an elongate neck and only granules on the chamber.

3. Cyathochitina gr. caputoi Da Costa 1971. Core 34, sample at $306.0 \mathrm{ft}$; IGR 72323 (N45/1), this specimen referred to the caputoi complex is one of the ultimate Cyathochitina recorded in the Qusaiba Member.

4, 6. Plectochitina jacquelineae sp. nov. Core 34, sample at $306.0 \mathrm{ft}$. (4a): paratype, IGR 72323 (R43); (4b): close up showing the crown of blunt short spines (ca. 10 
micrometers) extending from a very short carina. (6a): holotype, IGR 72323 (P43), specimen with spines directly erected on the margin; (6b): close up of the spines, which may have a very short branching distal end.

7. Armoricochitina crassicarinata sp. nov. Core 38, sample from $350.1 \mathrm{ft}$; IGR 72329 $(\mathrm{Q} 45 / 4)$.

Plate XV. Early Telychian chitinozoans (obtusa Biozone) from the Baq'a-3 core hole. Scale bar represents 100 micrometers, except for $7 \mathrm{~b}$ and 8 (10 micrometers).

1. Armoricochitina gengi sp. nov. Core 27, sample from $250.5 \mathrm{ft}$. Holotype, IGR 72316 (S45/1), well-developed membranous carina (up to 20 micrometers) and the microcorrugations on the chamber.

2. Spinachitina sp. Core 27, sample from 250.5 ft; IGR 72316 (R41/2), long subcylindrical chitinozoan carrying a crown of very short spines on its margin.

3, 7. Plectochitina lucasi sp. nov. Core 30, sample from $271.8 \mathrm{ft}$. (3): paratype, IGR 72319 (T43/1). (7a): holotype, IGR 72319 (T43/4), (7b) detail of the bi-rooted processes of the holotype.

4-5, 8-9. Plectochitina alisawyiahensis sp. nov. Core 30, sample from $271.8 \mathrm{ft}$. Various patterns of connection of the processes. (4): paratype, IGR 72319 (Q45/3). (5): paratype, IGR 72319 (R45); (8): paratype, IGR 72319 (R45/1), detail of connections in a "buckle-like" set of processes.

6. Plectochitina cf. alisawyiahensis sp. nov. Core 30, sample from 271.8 ft; IGR 72319 (Q45). This chitinozoan with a membranous carina extending into processes likely represents atypical Plectochitina alisawyiahensis sp. nov. with broken processes. 
9. Plectochitina alisawyiahensis sp. nov. Core 28, sample from $250.5 \mathrm{ft}$; paratype, IGR 72316 (R41/1), apertural view showing three sets of processes; in each set, the processes are connected through their tips.

Plate XVI. Early Telychian chitinozoans (obtusa Biozone) from the Baq'a-3 core hole.

Scale bar represents 100 micrometers.

1, 3, 9. Ancyrochitina cf. aculeata Taugourdeau and de Jekhowsky, 1960. Core 27, sample from 250.5 ft. (1): IGR $72316(\mathrm{O} 45)$, short form with serrate lips ending a short flaring neck. (3): IGR 72316 (N42/2). (9): IGR 72316 (S45).

2. Armoricochitina cf. gengi sp. nov. Core 21, sample from 192.5 ft; IGR 72310 (P36/4). The outline of this specimen recalls those of Conochitina elongata. However, the thickened rim running below the margin constitutes a true carina.

4. Conochitina elongata Taugourdeau, 1963. Core 27, sample from $250.5 \mathrm{ft}$; IGR 72316 (P42). Note the rim corresponding to the thickened margin.

5. Plectochitina paraguayensis Wood and Miller, 1991. Core 27, sample from $250.5 \mathrm{ft}$; IGR 72316 (Q45). This morphotype with broad processes and a rather short neck (length of the chamber close to the length of the neck) is regarded here as typical for this species (= P. paraguayensis form A in Paris, 1993).

6. Tanuchitina obtusa (Taugourdeau and de Jekhowsky, 1960). Core 27, sample from $250.5 \mathrm{ft}$; IGR $72316(\mathrm{R} 46 / 2)$.

7. Plectochitina longicornis (Taugourdeau and de Jekhowsky, 1960). Core 27, sample from $250.5 \mathrm{ft}$; IGR 72316 (O42). This species with very long and slender processes (up to two times the vesicle length) and a well-developed cylindrical neck has been 
identified previously as Plectochitina paraguayensis form B in Paris (1993).

8. Pterochitina deichaii Taugourdeau, 1963. Core 21, sample from 192.5 ft; IGR 72310 (O42/3). Chain of three buckled and flattened vesicles.

Plate XVII. Early Telychian chitinozoans from the Baq'a-3 core hole. Scale bar represents 100 micrometers, except for $1 b, 2 b$ and 6 (10 microns).

1. Armoricochitina cf. gengi sp. nov. Core 16, sample from 150.4 ft; IGR 72304 (N42/3). The widened chamber results from its partial flattening. (1b): large protruding apical structure composed of a large rim surrounding a flat area and a small central pit.

2. Armoricochitina cf. gengi sp. nov. Core 18, sample from $170.9 \mathrm{ft}$; IGR 72307 (R40/1). This specimen recalls some short Tanuchitina species (see discussion in the Systematic section).

3-5. Fungochitina? sp. Core 18, sample from $170.9 \mathrm{ft}$. A crown of robust cones occurs on the margin; smaller cones are randomly dispersed on the fungiform chamber and on the neck of these specimens. (3): IGR 72307 (O41), three dimensional fungiform chamber; (4): IGR 72316 (Q38/4) (5): IGR 72316 (P40/2).

6, 8. Calpichitina cf. acollaris (Eisenack 1959). Core 18, sample from 170.9 ft. (6): vesicle in antiapertural view, IGR 72307 (O39/4). (8): IGR 72307 (O40), operculum within the chamber; this specimen is significantly smaller than the Baltic species.

7. Plectochitina sp. Core 21, sample from 192.5 ft; IGR 72310 (Q41/1).

Plate XVIII. Early Telychian chitinozoans (silurica Biozone) from the Baq'a-3 core hole. 
Scale bar represents 100 micrometers, except for $1 \mathrm{~b}$ and $2 \mathrm{~b}$ (10 micrometers).

1-2. Plectochitina cf. lucasi sp. nov. Core 14, sample from 130.0 ft. (1a): IGR 72302 (P46), (1b): processes with bi-rooted proximal parts. (2a): IGR 72302 (P48), slender vesicle; most of the granules on the vesicle wall are artefacts; (2b): detail of the bi-rooted processes.

3-4. Euconochitina silurica (Taugourdeau, 1963). Core 14, sample from 130.0 ft. (3): IGR 72302 (Q49/3), small vesicle with slightly serrate lips. (4): IGR 72302 (R44/4), partly compressed vesicle with an "extruded" bottom showing an apical mark. N.B. Conochitina oelandica subsp. silurica defined by Taugourdeau (1963, p. 134-137) is raised here to specific level.

5. Armoricochitina gengi sp. nov. Core 16, sample from 150.4 ft; IGR 72304 (O45), membranous carina folded and stuck above the margin.

6. Tanuchitina obtusa (Taugourdeau and de Jekhowsky, 1960). Core 16, sample from 150.4 ft; IGR 72304 (Q43), slender and gently tapering conical vesicle; less cylindrical than T. cylindrica (Taugourdeau and de Jekhowsky, 1960).

7. Plectochitina sp. aff. alisawyiahensis sp. nov. Core 16, sample from $150.4 \mathrm{ft}$; IGR 72307 (N42), specimen tentatively referred to $P$. alisawyiahensis because of its general outline and the size of its spongy processes.

8. Ancyrochitina aculeata Taugourdeau and de Jekhowsky, 1960. Core 16, sample from $150.4 \mathrm{ft}$; IGR 72307 (N41/4). 
Table 1

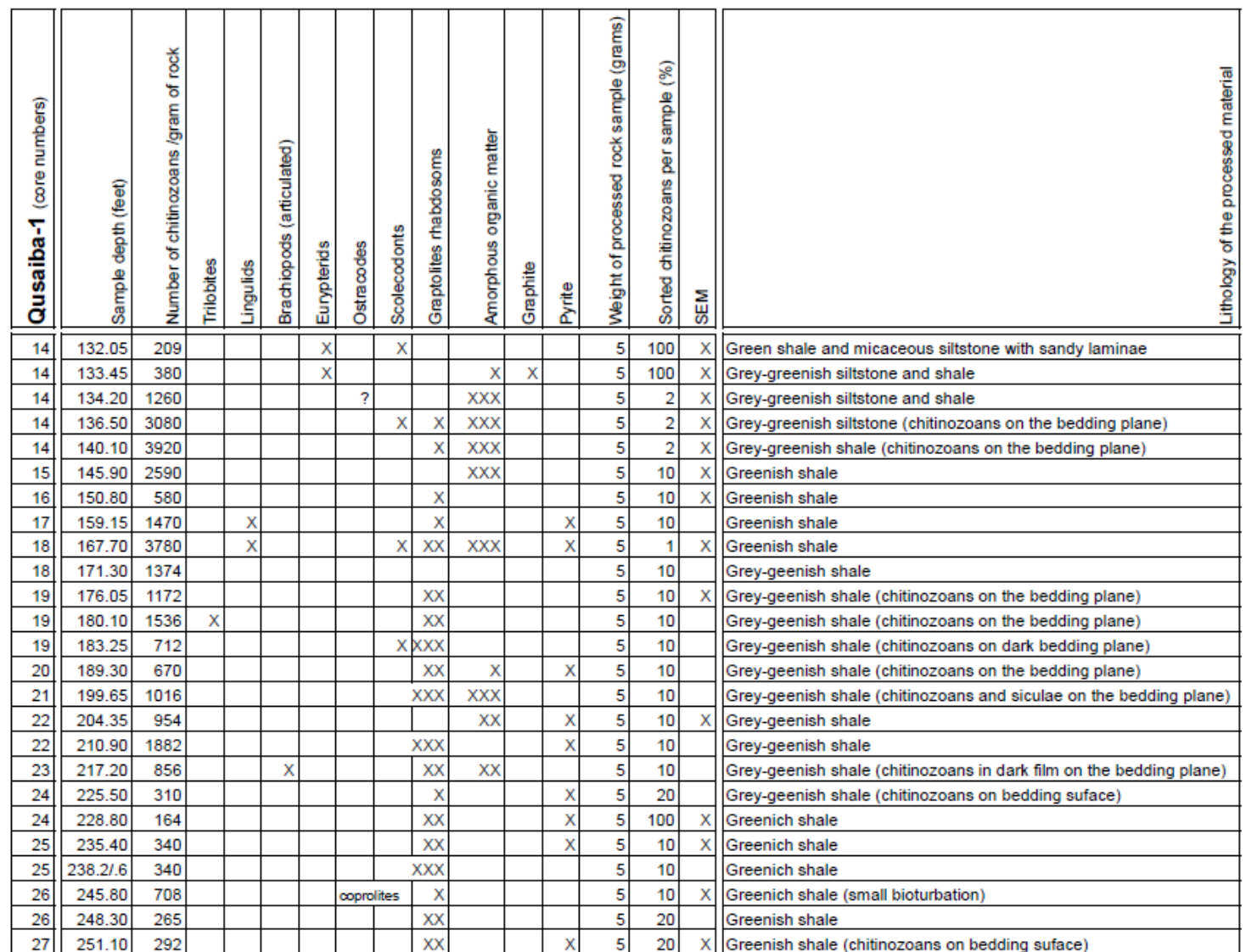


Table 2

\begin{tabular}{|c|c|c|c|c|c|c|c|c|c|c|c|}
\hline 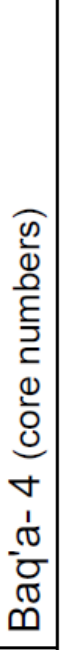 & 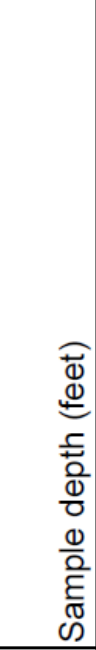 & 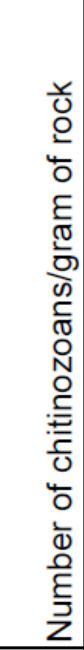 & 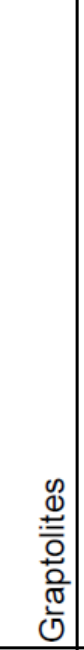 & 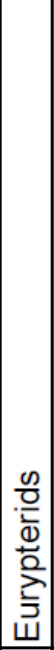 & 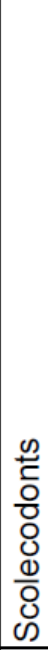 & 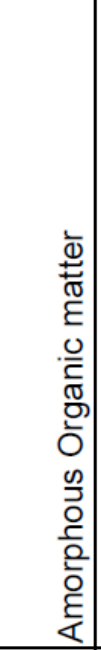 & 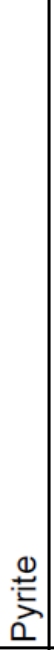 & 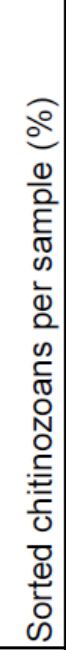 & 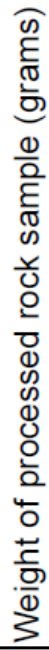 & 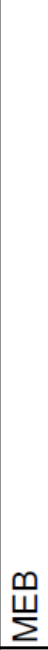 & 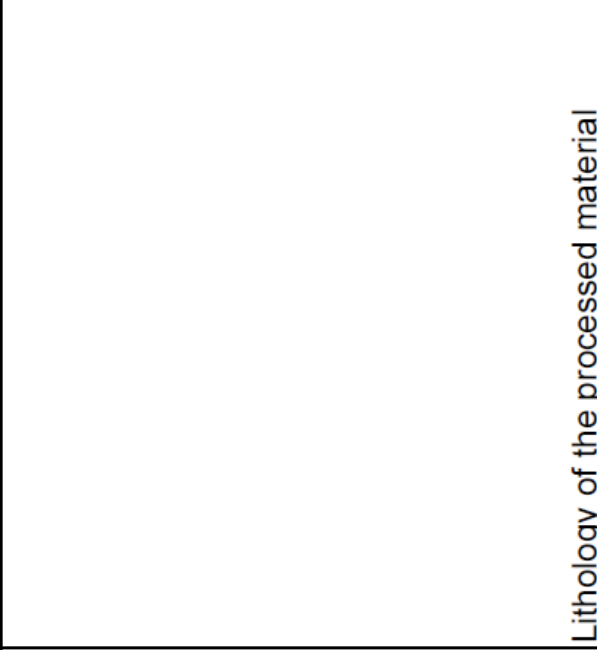 \\
\hline 7 & 40.1 & 470 & $\mathrm{X}$ & & & $\bar{x}$ & & 10 & 5 & & grey silty-shale \\
\hline 9 & 60.1 & 110 & $\overline{X X X}$ & $\mathrm{X}$ & $\mathrm{X}$ & $\mathrm{X}$ & & 20 & 5 & & grey silty-shale \\
\hline 11 & 80.3 & 680 & $\mathrm{XX}$ & & & $\mathrm{XXX}$ & $\mathrm{X}$ & 1 & 5 & & grey-greenish shale, silty-shale laminae \\
\hline 13 & 100.0 & 1120 & $\mathrm{XX}$ & & & $\mathrm{XXXX}$ & & 2 & 5 & & grey shale, white laminae, grey-green part \\
\hline 15 & 120.1 & 124 & $\overline{X X X}$ & & & $\mathrm{X}$ & & 10 & 5 & & grey-greenish shale \\
\hline 17 & 140.6 & 1774 & $\overline{X X X}$ & & & $\mathrm{XXX}$ & & 10 & 5 & & grey-greenish shale \\
\hline 19 & 163.0 & 182 & $\mathrm{XX}$ & & & $\mathrm{X}$ & & 10 & 5 & & grey-greenish shale, small muscovites \\
\hline 21 & 180.4 & 190 & & & & $\mathrm{X}$ & & 10 & 5 & & grey-greenish shale, laminae \\
\hline 23 & 201.2 & 220 & $\mathrm{X}$ & & & $\mathrm{X}$ & & 10 & 5 & & grey shale, white laminae, grey-green part \\
\hline 26 & 221.2 & 190 & $\mathrm{X}$ & & & $\mathrm{XXX}$ & & 10 & 5 & & grey-greenish shale \\
\hline 28 & 240.7 & 30 & $\mathrm{X}$ & & & $\mathrm{X}$ & & 100 & 5 & $\mathrm{X}$ & grey shale, white silty laminae \\
\hline 30 & 261.2 & 1950 & $\overline{X X X}$ & & & $\mathrm{XX}$ & & 2 & 5 & & grey shale and silty-shale \\
\hline 31 & 269.0 & 1466 & $\mathrm{X}$ & & & $\mathrm{XXX}$ & $\mathrm{X}$ & 2 & 5 & & grey shale, white silty laminae \\
\hline
\end{tabular}


Table 3

\begin{tabular}{|c|c|c|c|c|c|c|c|c|c|c|c|c|c|}
\hline 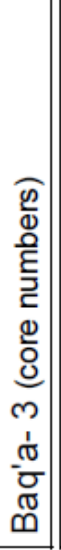 & 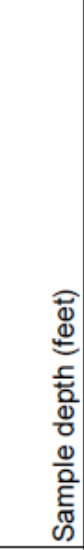 & 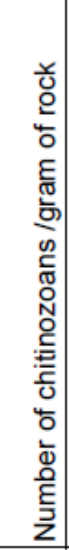 & 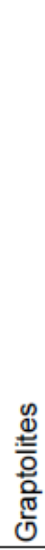 & 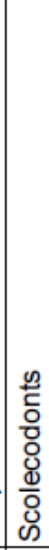 & 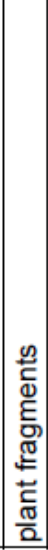 & 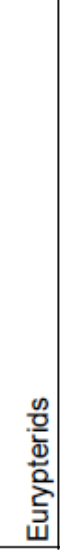 & 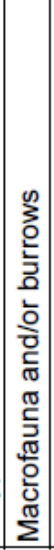 & . & 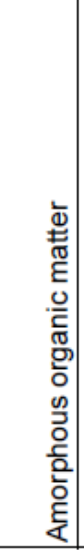 & 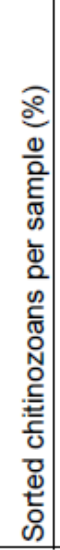 & 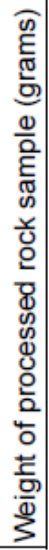 & & 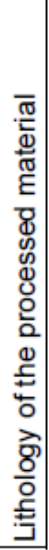 \\
\hline 14 & 130.0 & 27 & & & $?$ & $\mathrm{XX}$ & $\mathrm{x}$ & & $\mathrm{X}$ & 80 & 5 & grey siltstone+white sandy laminae & \\
\hline 16 & 150.4 & 274 & & & & $\mathrm{X}$ & & $\mathrm{X}$ & $\mathrm{XX}$ & 10 & 10 & grey-greenish shale, small muscovites & \\
\hline 18 & 170.9 & 240 & & & $?$ & $\mathrm{x}$ & & $\mathrm{X}$ & $\mathrm{XX}$ & 10 & 5 & grey shale, small muscovites & \\
\hline 21 & 192.5 & 51 & & & & $\mathrm{XX}$ & & & $\mathrm{XX}$ & 100 & 5 & grey shale, sliding surfaces & \\
\hline 22 & 206.9 & 57 & $\bar{X}$ & & & $\mathrm{x}$ & $\mathrm{x}$ & & $\mathrm{XX}$ & 100 & 5 & grey shale, silty-shale & \\
\hline 25 & 229.7 & 1038 & $\bar{x}$ & & & & & $\mathrm{X}$ & $\mathrm{XX}$ & 10 & 5 & fine grey siltstone, small muscovites & \\
\hline 27 & 250.5 & 410 & & & & $\mathrm{x}$ & & $\mathrm{x}$ & $\mathrm{XX}$ & 10 & 5 & grey-greenish shale, small muscovites & \\
\hline 30 & 271.8 & 602 & & & & & & $\mathrm{x}$ & $\mathrm{XX}$ & 10 & 5 & fine grey siltstone, small muscovites & \\
\hline 32 & 289.1 & 1840 & & & & & & $\mathrm{X}$ & $\mathrm{XXX}$ & 2 & 5 & grey-greenish shale, small muscovites & \\
\hline 34 & 306.0 & 1090 & $\mathrm{X}$ & & & & & & $\mathrm{XXX}$ & 2 & 5 & grey-greenish silty-shale & \\
\hline 36 & 330.4 & 85 & $\mathrm{x}$ & & & $\mathrm{XX}$ & & & $\mathrm{X}$ & 20 & 5 & grey-greenish silty-shale & \\
\hline 38 & 350.1 & 542 & $\mathrm{x}$ & & & $\mathrm{x}$ & & & $\mathrm{XX}$ & 10 & 5 & grey-greenish shale+ white siltstone laminae & \\
\hline 40 & 370.4 & 1230 & & $\mathrm{X}$ & & & & & $\mathrm{XXX}$ & 10 & 5 & grey-greenish shale, small muscovites & \\
\hline 42 & 388.0 & 424 & $\mathrm{X}$ & & & & & & $\mathrm{XXXX}$ & 10 & 5 & grey-greenish shale & \\
\hline 45 & 408.7 & 67 & $\mathrm{x}$ & & & $\mathrm{X}$ & & & $x X$ & 100 & 5 & grey-greenish shale & \\
\hline 47 & 431.7 & 348 & & & & & & & $x X X X$ & 5 & 5 & $\begin{array}{l}\text { grey-greenish shale } \\
\text { grats }\end{array}$ & \\
\hline 49 & 450.1 & 94 & $\bar{X}$ & & & & & & $X X$ & 20 & 5 & grey-greenish shale & \\
\hline 51 & 469.8 & 620 & $\bar{X}$ & & & & & & $\mathrm{XX}$ & 2 & 5 & grey-greenish shale & \\
\hline 54 & 490.3 & 1680 & $\bar{X}$ & & & & & & $\mathrm{XXX}$ & 2 & 5 & grey-greenish shale & \\
\hline 56 & 518.3 & 1400 & $\underline{X}$ & & & & & & $X X X X$ & 2 & 10 & grey-greenish shale, dark grey laminae & \\
\hline
\end{tabular}


Table 19

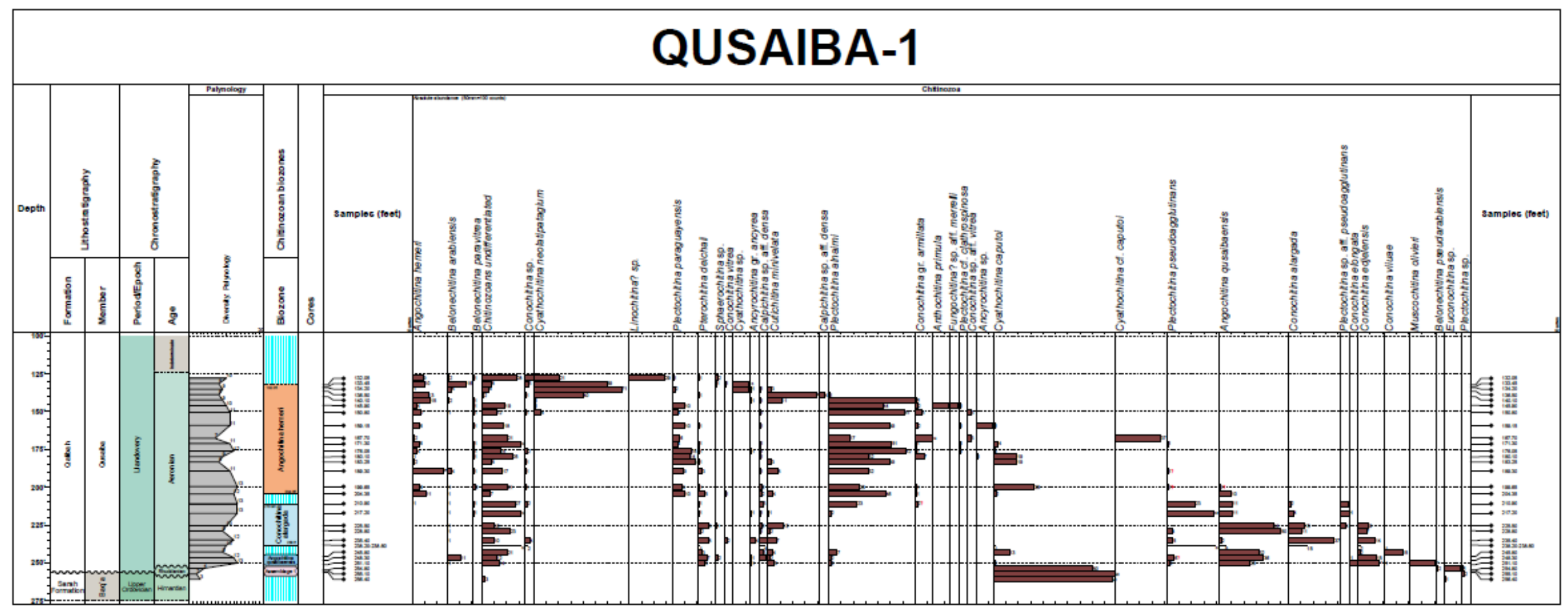


Table 20

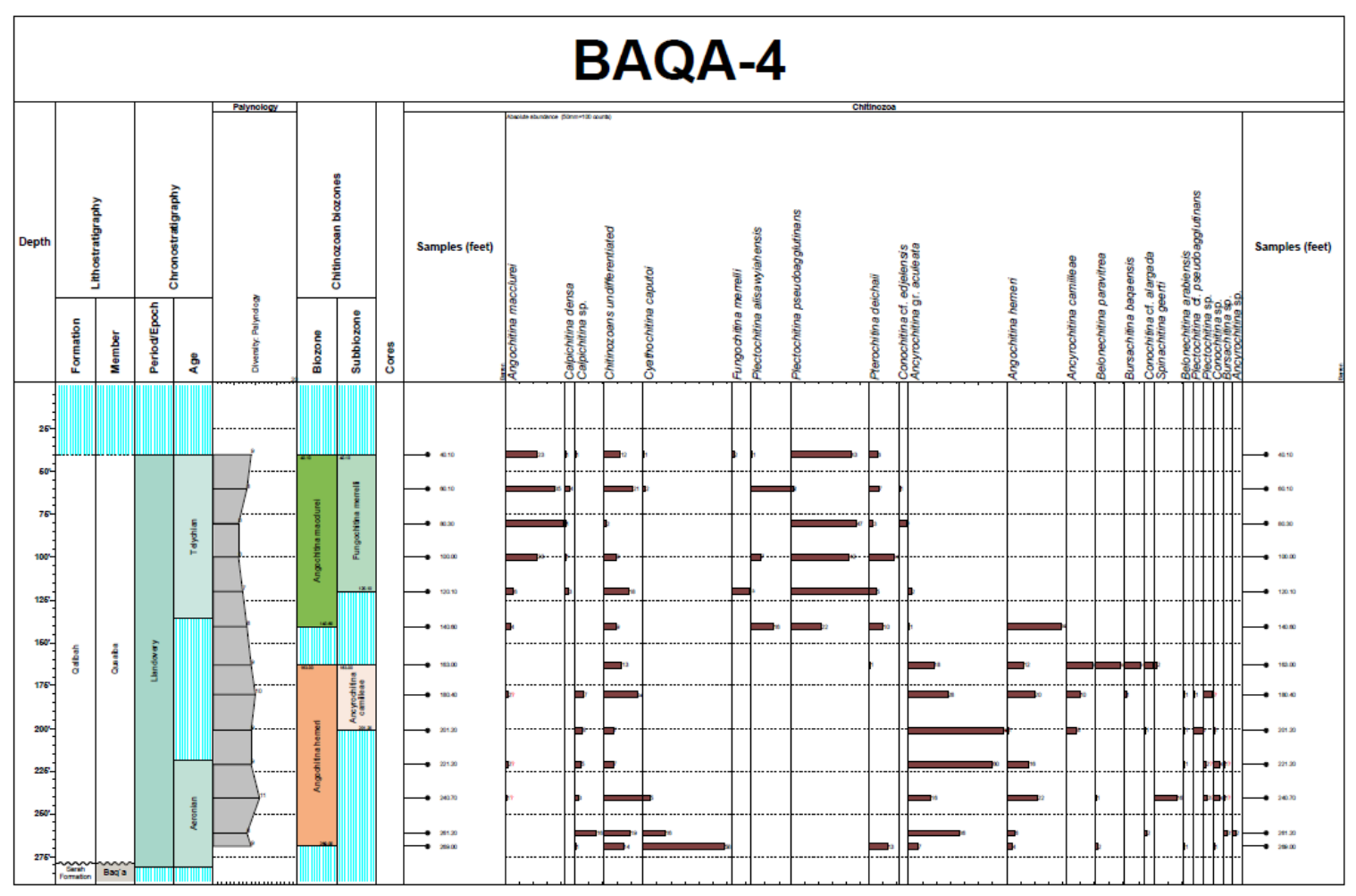


Table 21

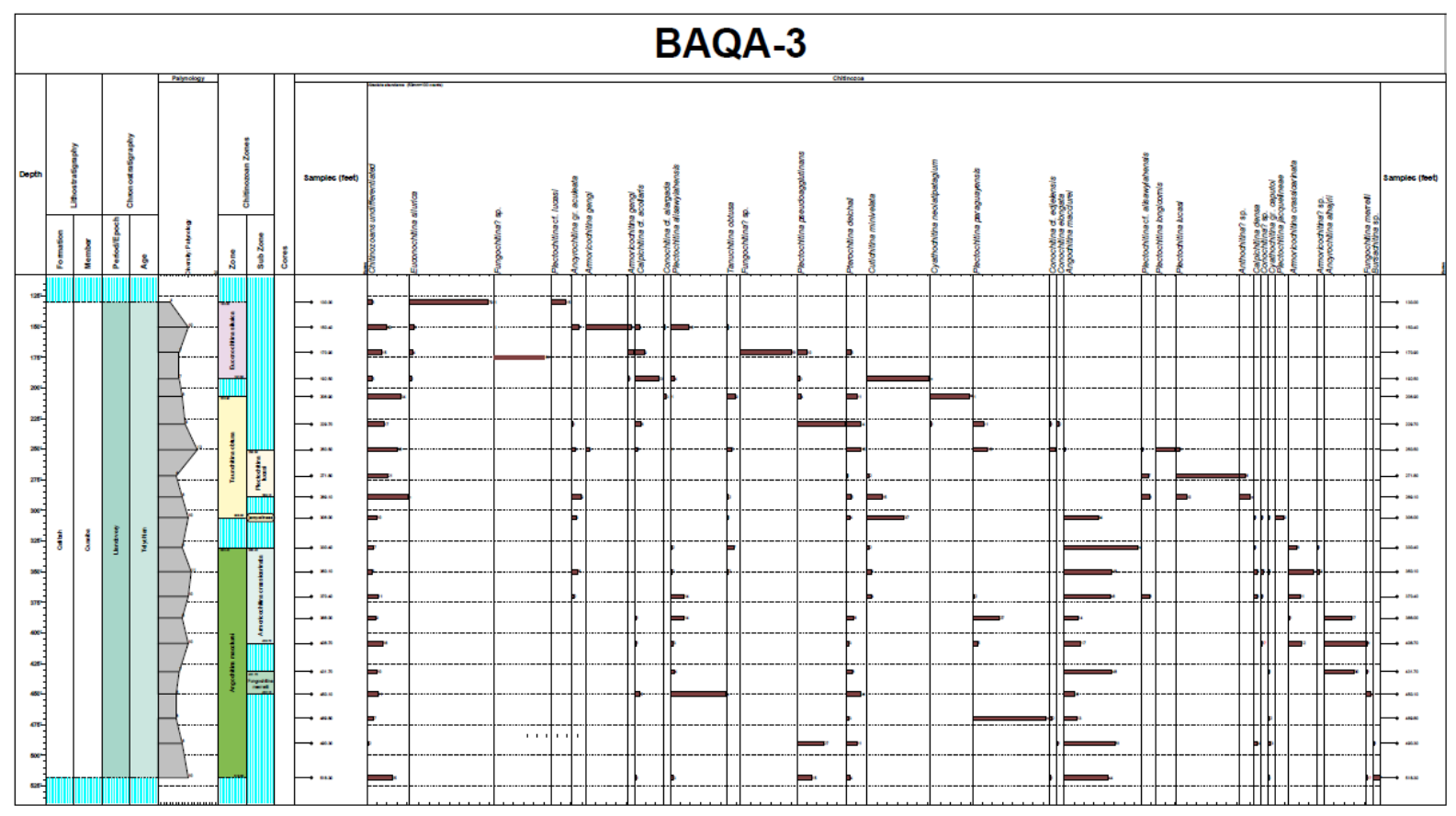


Table 22

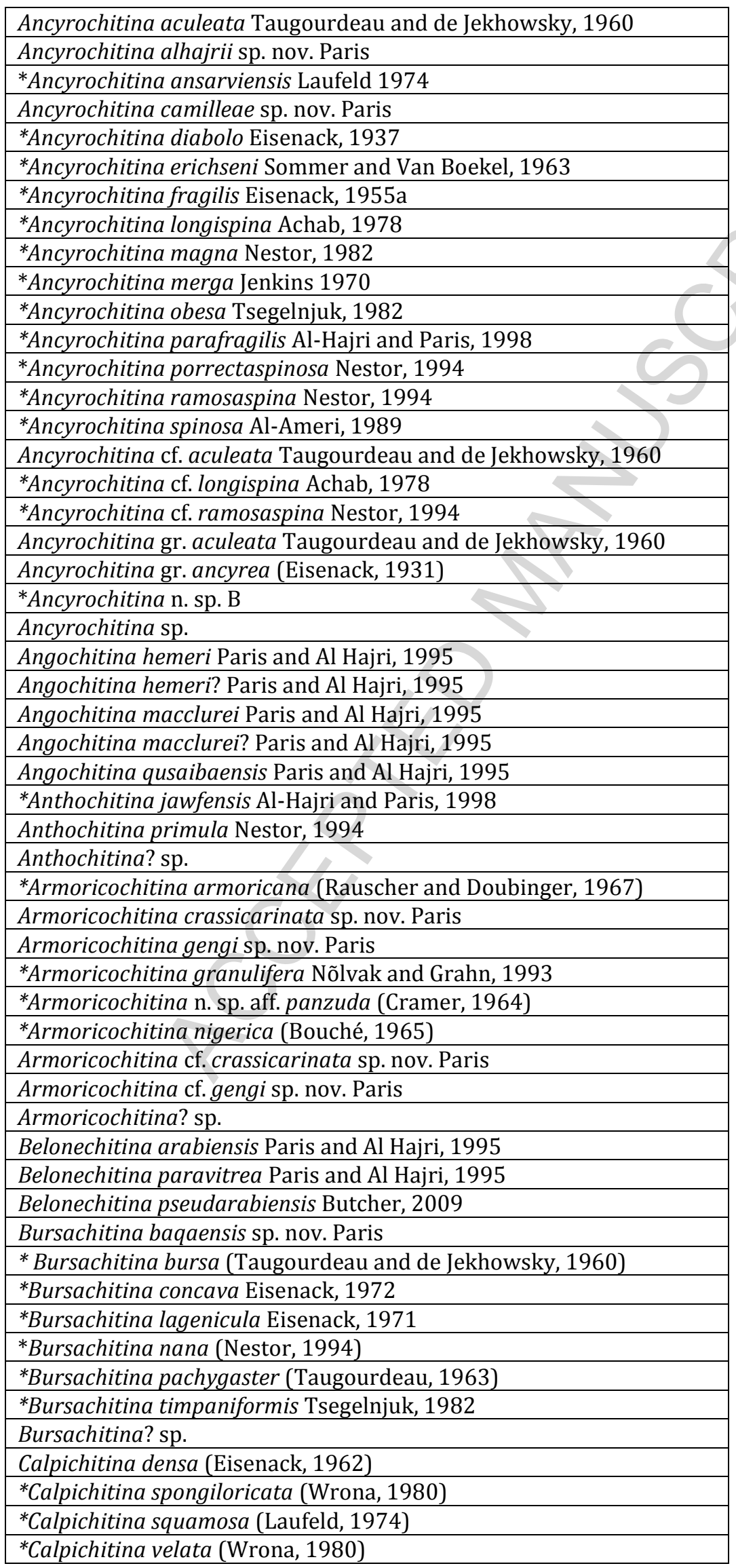


Calpichitina cf. acollaris (Eisenack, 1959)

Calpichitina sp. aff. densa (Eisenack, 1962)

Calpichitina sp.

${ }^{*}$ Cingulochitina bouniensis Verniers, 1999

*Cingulochitina burdinalensis Verniers, 1999

* Cingulochitina serrata (Taugourdeau and de Jekhowsky, 1960)

*Clathrochitina clathrata Eisenack, 1959

*Clathrochitina sylvanica Jenkins, 1970

Conochitina alargada Cramer, 1967

*Conochitina campanulaeformis Eisenack 1931

*Conochitina claviformis Eisenack, 1931

Conochitina edjelensis Taugourdeau, 1963

Conochitina elongata Taugourdeau, 1963

* Conochitina fungiformis Eisenack, 1931

${ }^{*}$ Conochitina incerta Eisenack, 1962

*Conochitina leptostoma Laufeld, 1974

*Conochitina praeproboscifera Nestor, 1994

*Conochitina proboscifera Eisenack, 1937

*Conochitina rara Nestor, 1994

*Conochitina rotundata sp. nov. Paris et al. (this volume)

Conochitina vitrea (Taugourdeau, 1962)

Conochitina viiuae sp. nov. Paris

Conochitina cf. alargada Cramer, 1967

Conochitina cf. edjelensis Taugourdeau, 1963

Conochitina gr. armillata Taugourdeau and de Jekhowsky, 1960

Conochitina sp. aff. vitrea (Taugourdeau, 1962)

Conochitina sp.

Conochitina? sp.

* Conochitina spp.

*Cutichitina legrandi Achab, Asselin and Soufiane, 1993

Cutichitina minivelata sp. nov. Paris

*Cyathochitina campanulaeformis (Eisenack 1931)

Cyathochitina caputoi Da Costa, 1971

*Cyathochitina kuckersiana (Eisenack, 1934)

${ }^{*}$ Cyathochitina latipatagium Jenkins, 1969

Cyathochitina neolatipatagium sp. nov. Paris

Cyathochitina cf. caputoi Da Costa, 1971

Cyathochitina gr. caputoi Da Costa, 1971

Cyathochitina sp.

Euconochitina silurica (Taugourdeau, 1963

Euconochitina sp.

*Fungochitina bernesgae (Cramer, 1967)

*Fungochitina hispida (Taugourdeau and de Jekhowsky, 1960)

${ }^{*}$ Fungochitina illinoisensis Butcher, Mikulic and Kluessendorf, 2010

Fungochitina merrelli sp. nov. Paris

${ }^{*}$ Fungochitina pilosa (Collinson and Scott, 1958)

Fungochitina? sp. aff. merrelli sp. nov. Paris

Fungochitina? sp.

${ }^{*}$ Hoegisphaera complanata (Eisenack, 1932)

${ }^{*}$ Lagenochitina nuayyimensis Paris and Al-Hajri, 1995

* Linochitina ceneratiensis Paris, 1976

* Linochitina cingulata (Eisenack, 1937)

Linochitina? sp.

*Margachitina banwyensis Mullins, 2000

*Margachitina margaritana (Eisenack, 1937)

*? Margachitina leonensis (Cramer, 1964)

Muscochitina olivieri sp. nov. Paris 


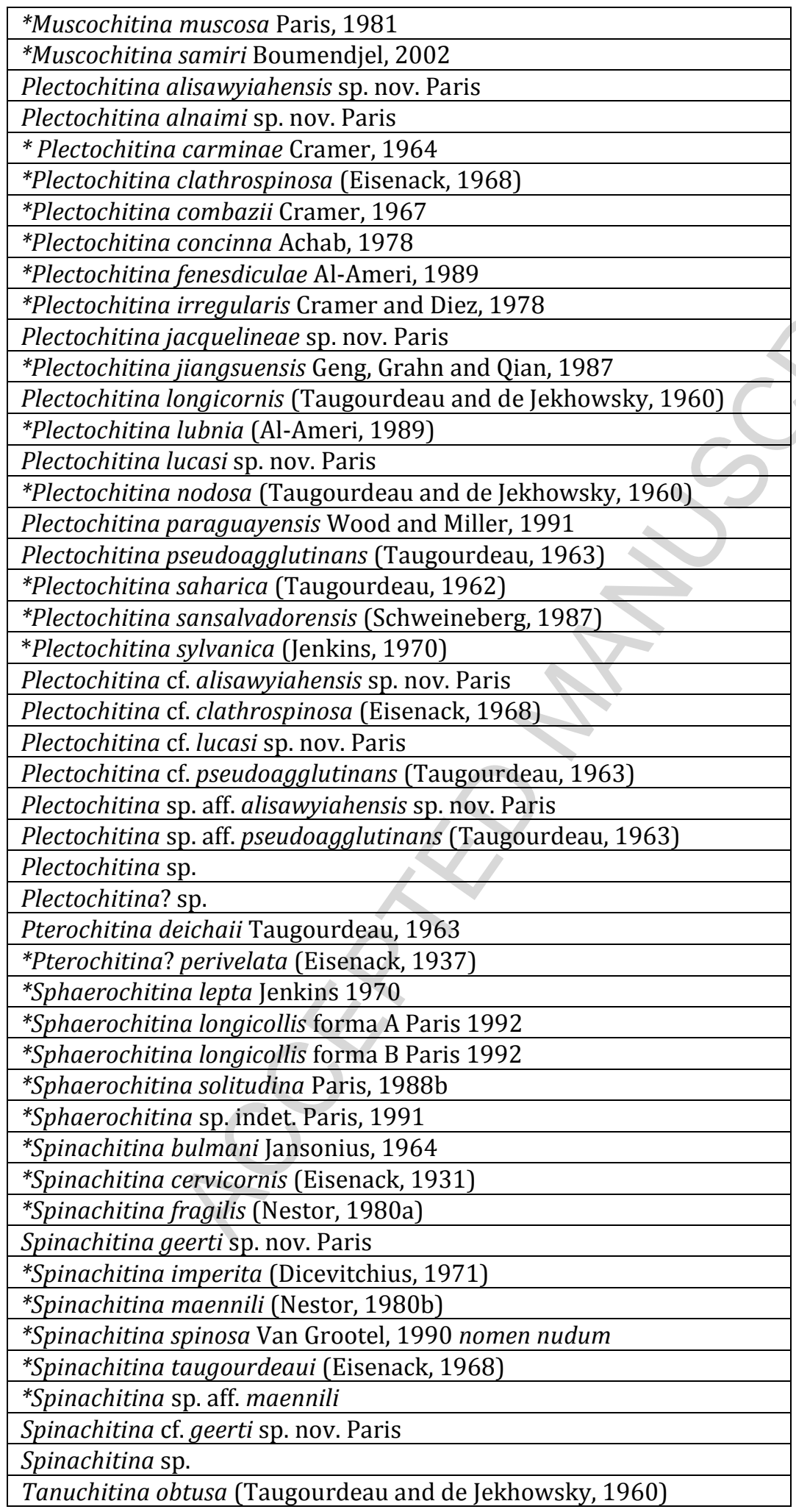




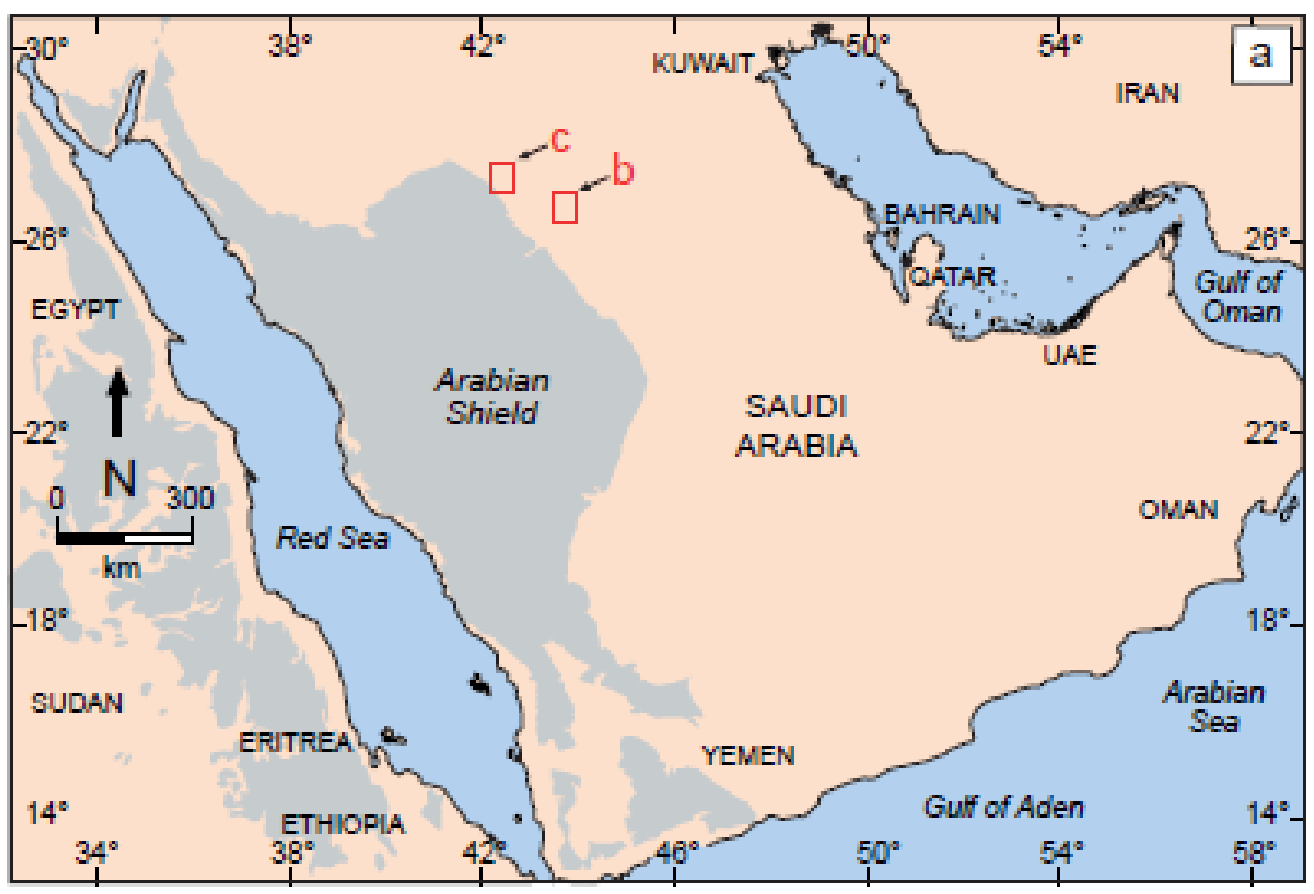




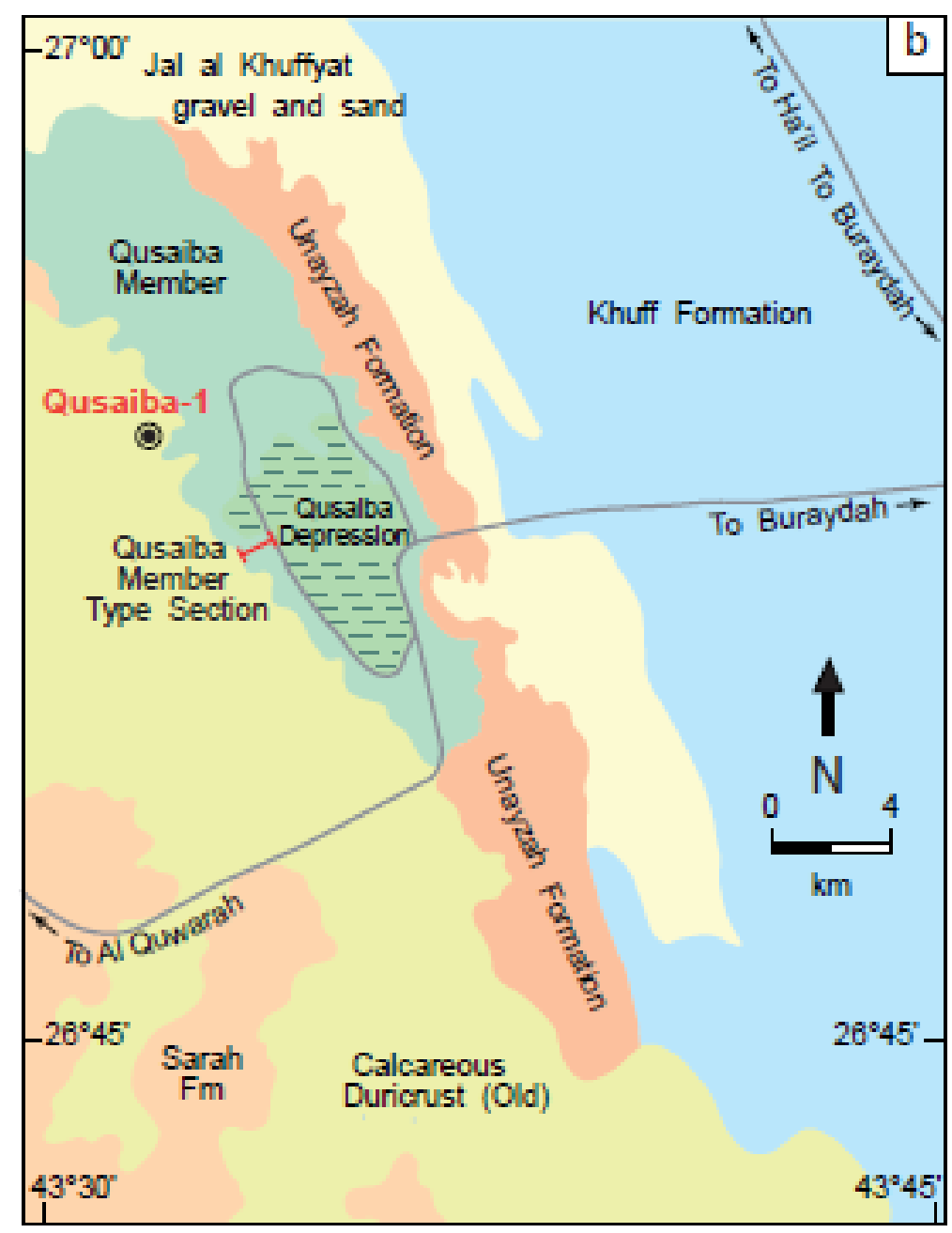




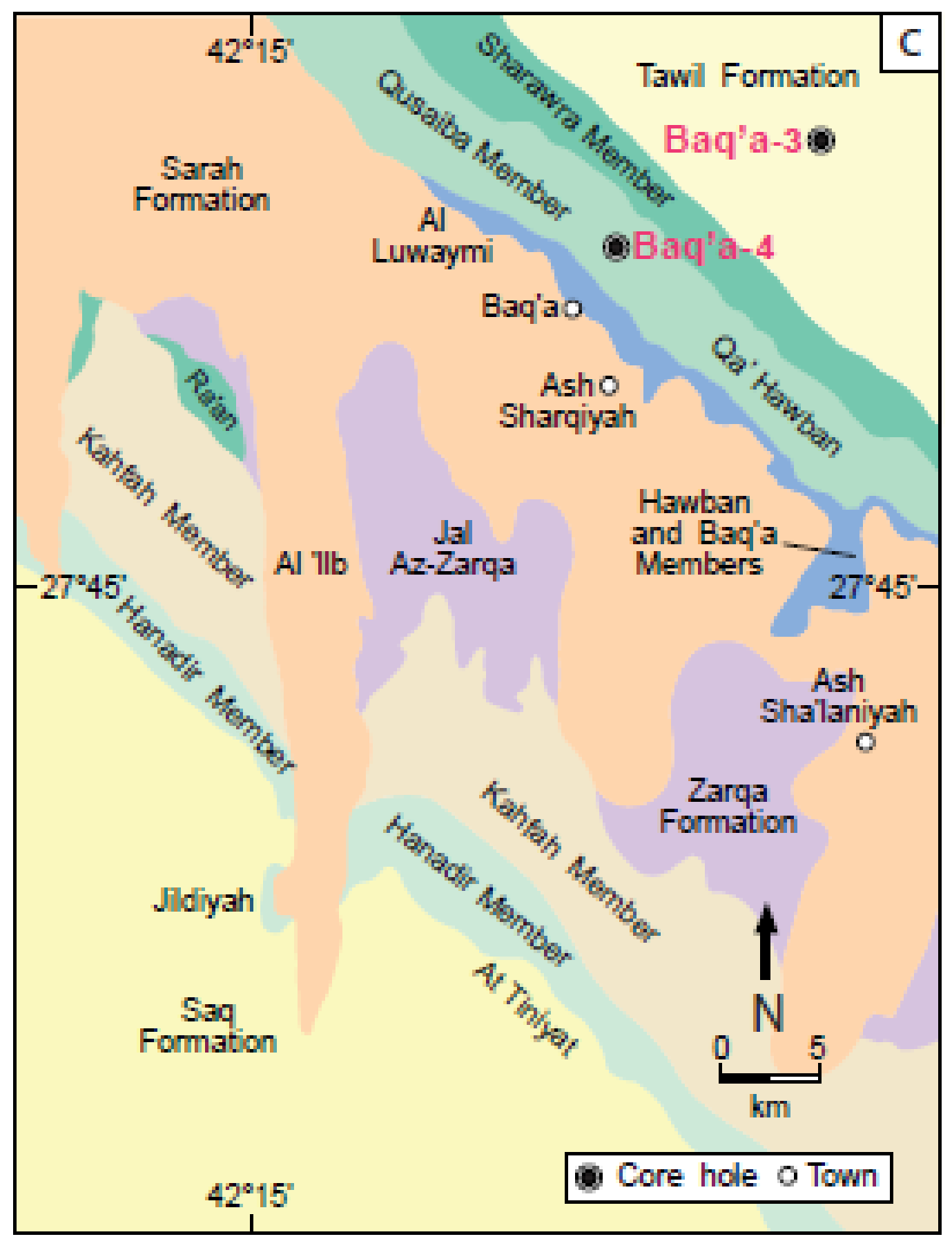

Figure 1 


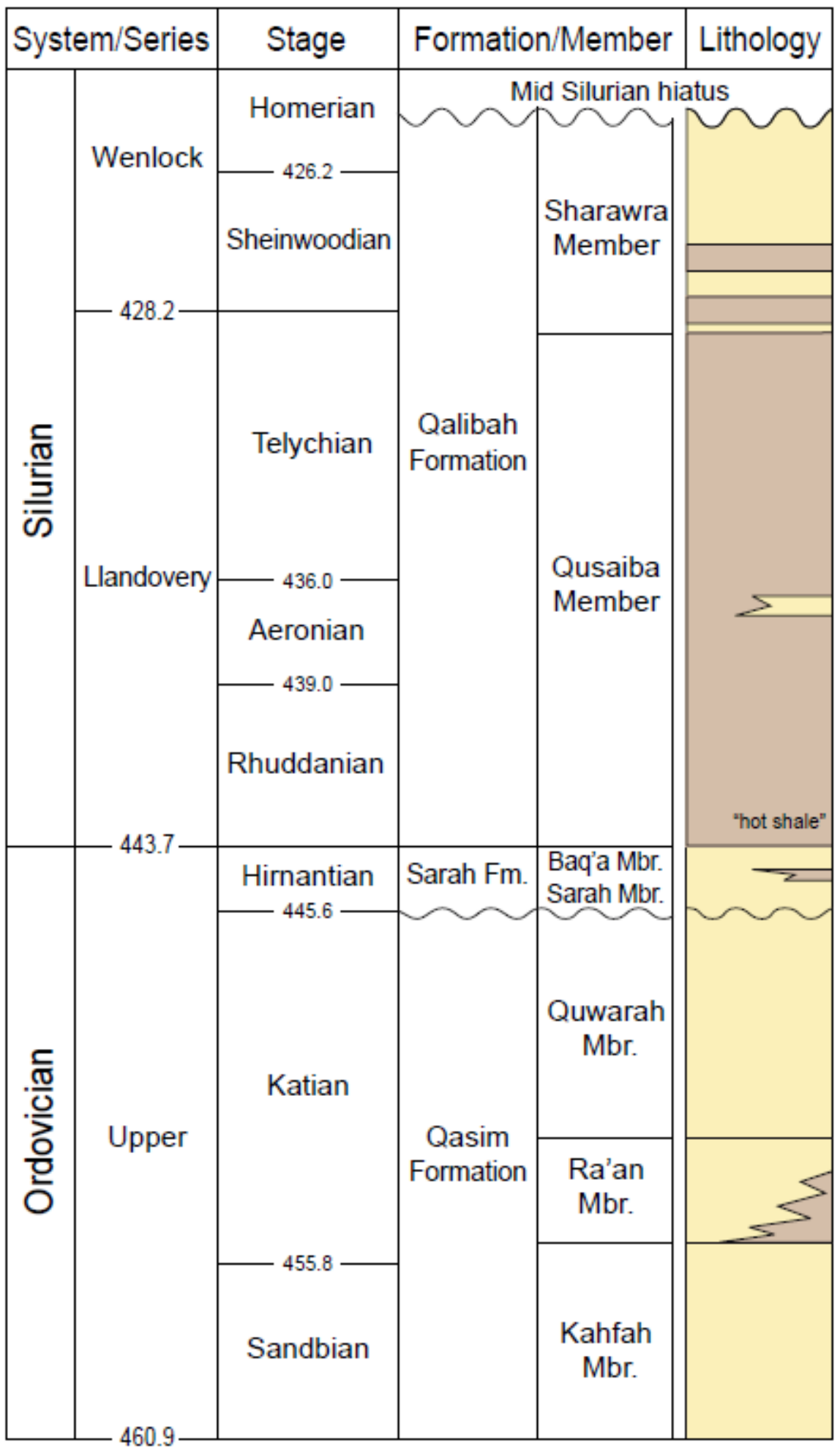

Figure 2 


\section{Qusaiba-1}

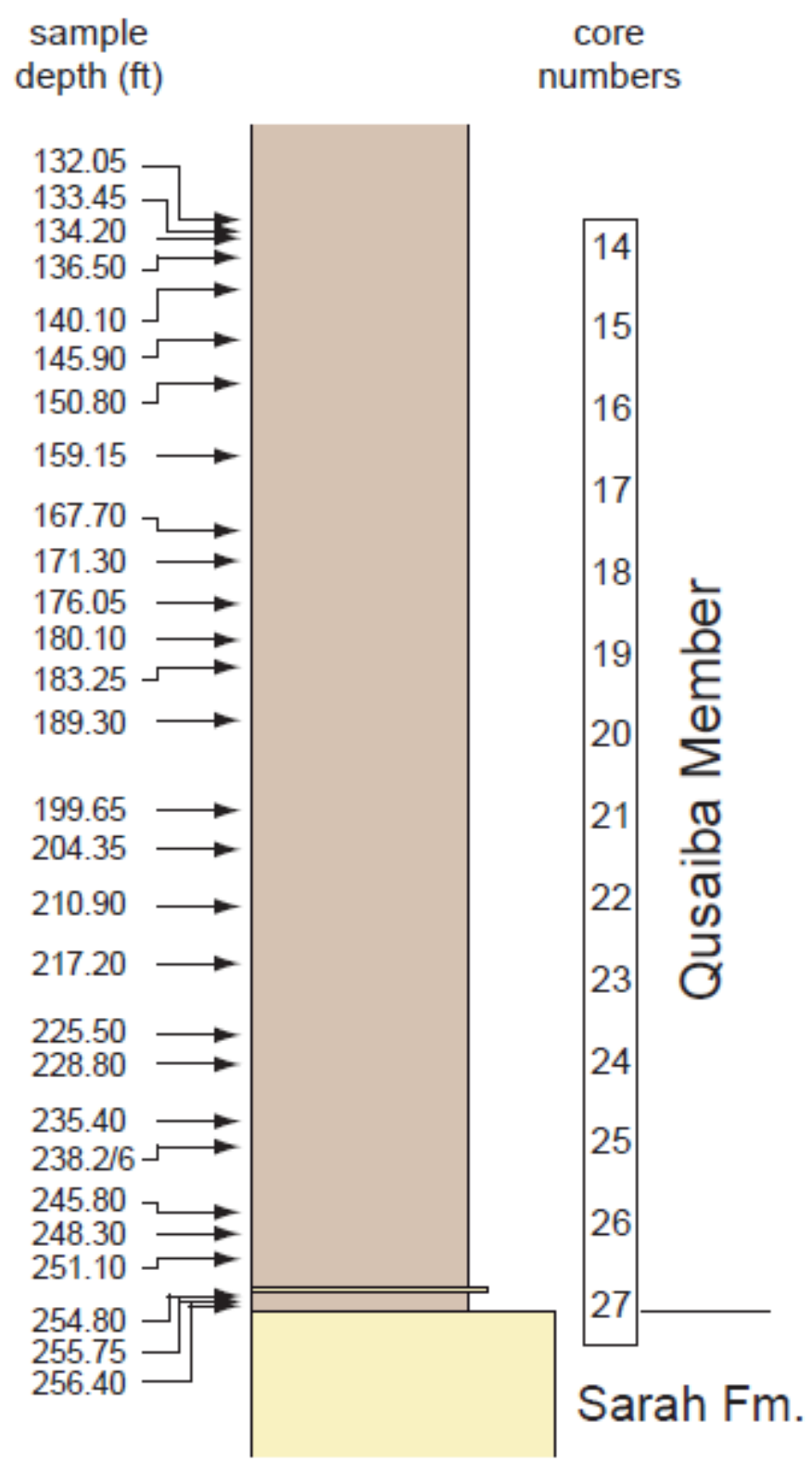

Figure 3 


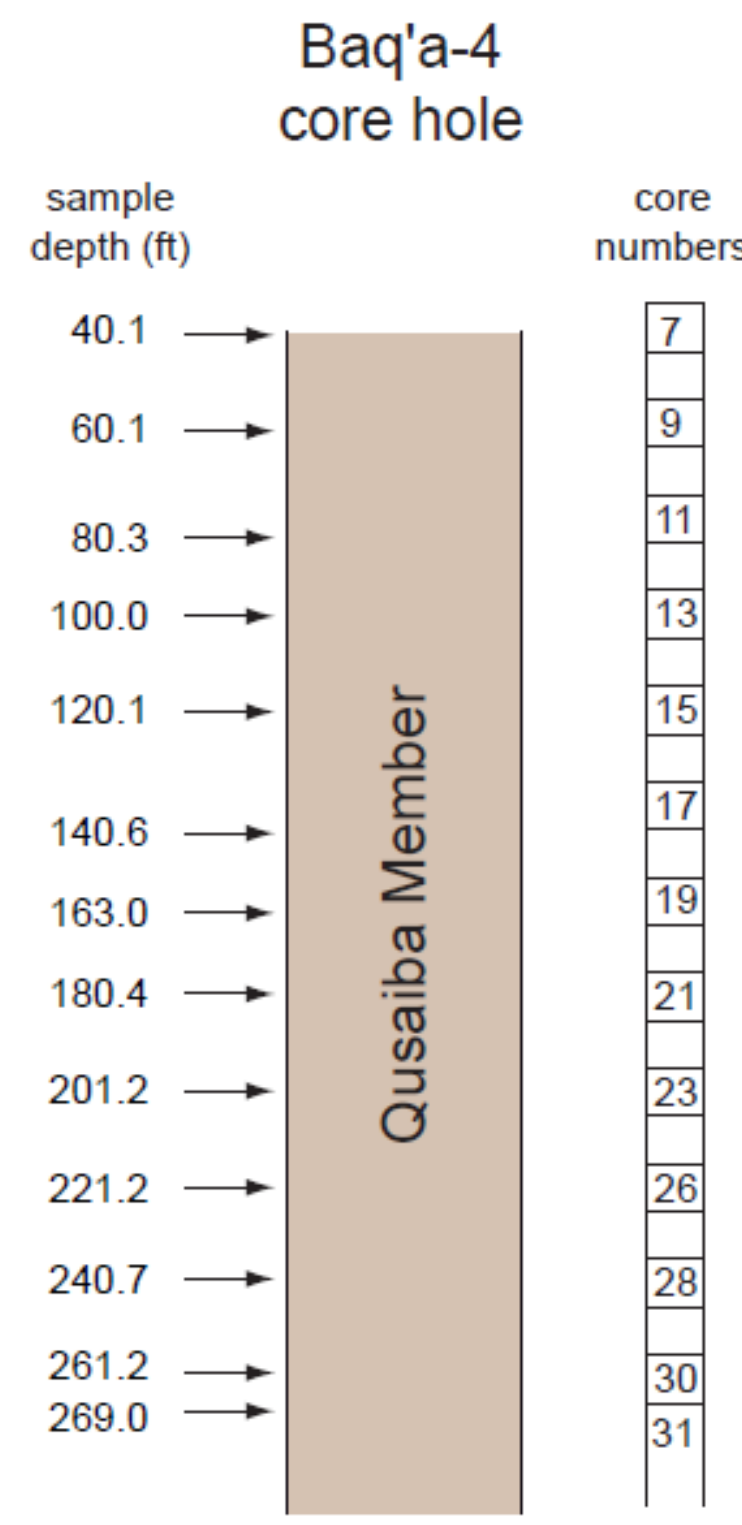

Figure 4 


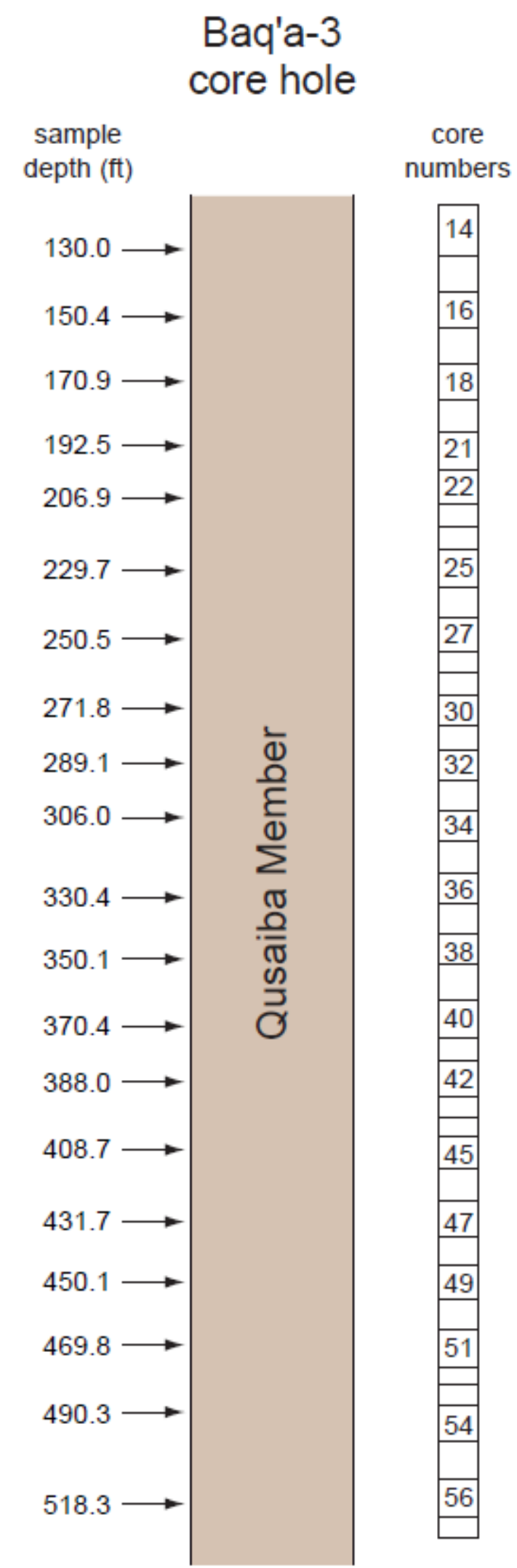

Figure 5 


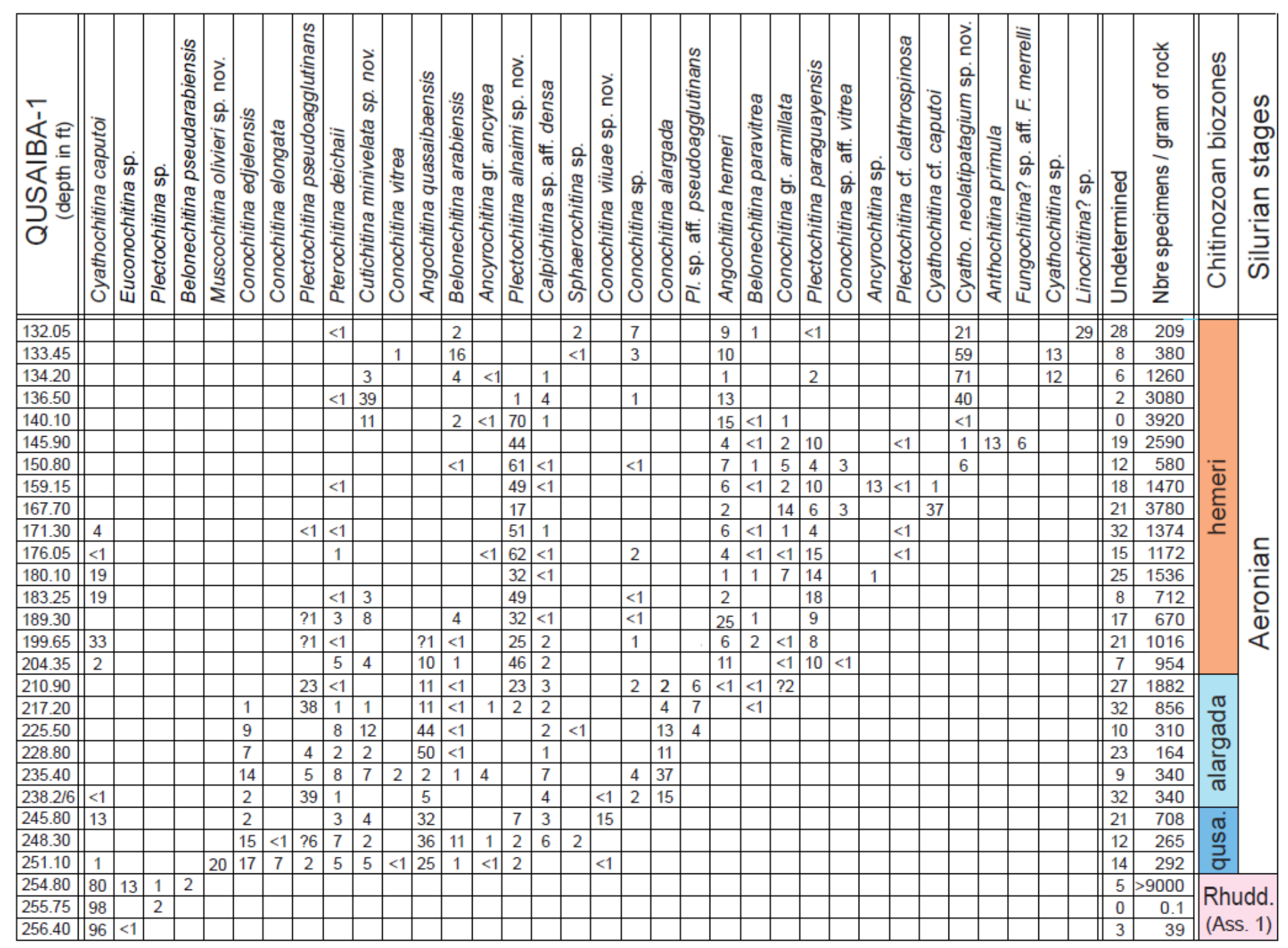

Figure 6 


\begin{tabular}{|c|c|c|c|c|c|c|c|c|c|c|c|c|c|c|c|c|c|c|c|c|c|c|c|c|c|c|c|}
\hline 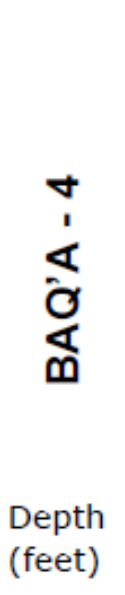 & 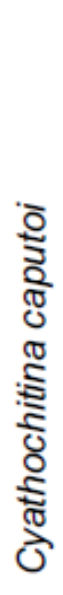 & 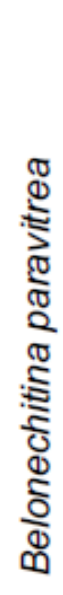 & 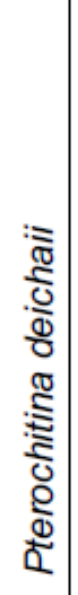 & 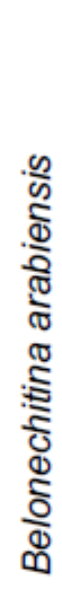 & 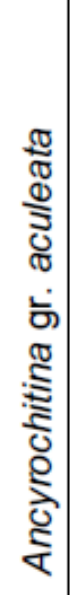 & 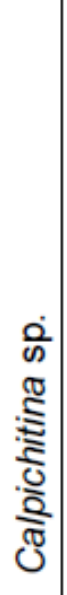 & 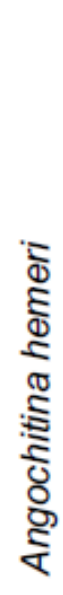 & 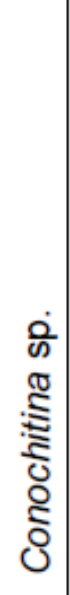 & 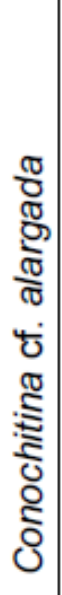 & 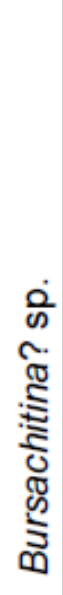 & 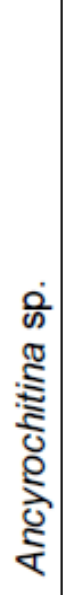 & 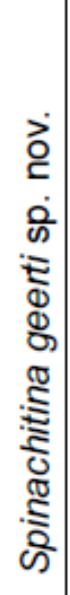 & 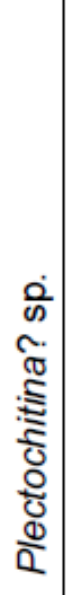 & 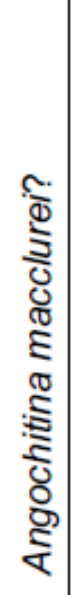 & 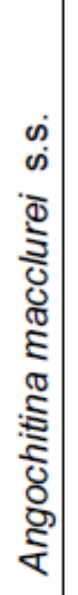 & 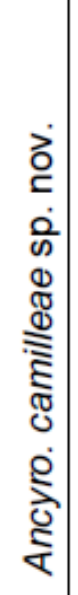 & 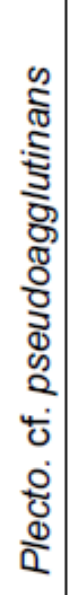 & 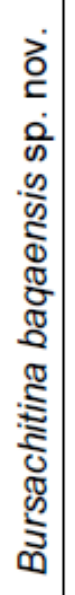 & 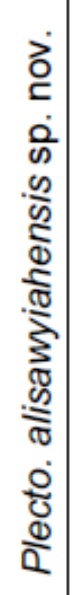 & 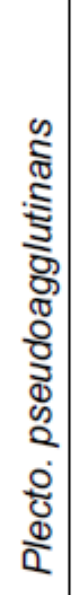 & 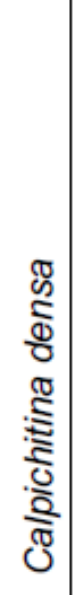 & 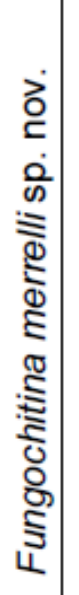 & 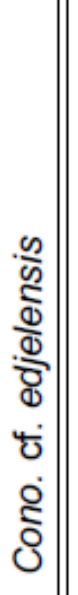 & 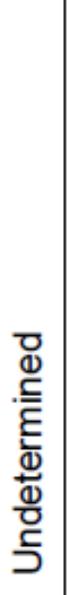 & 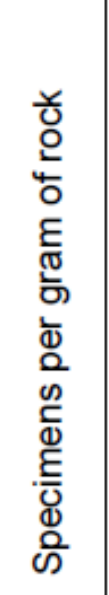 & 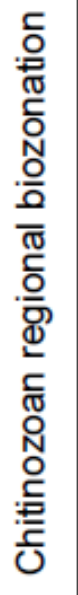 & 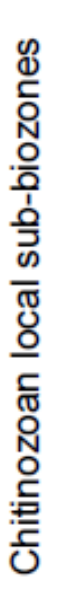 \\
\hline 40.1 & $<1$ & & 6 & & & 1 & & & & & & & & & 23 & & & & 1 & 43 & $<1$ & 2 & & 12 & 470 & \multirow{6}{*}{$\begin{array}{l}\text { '홀 } \\
\text { 릉 } \\
\text { हू } \\
\text { हू }\end{array}$} & \multirow{5}{*}{$\begin{array}{l}\stackrel{\overline{\bar{D}}}{\frac{\mathrm{L}}{\Phi}} \\
\text { है }\end{array}$} \\
\hline 60.1 & 2 & & 7 & & & & & & & & & & & & 35 & & & & 28 & 2 & 4 & & 1 & 21 & 110 & & \\
\hline 80.3 & & & 3 & & & & & & & & & & & & 41 & & & & & 47 & 1 & & 6 & 2 & 680 & & \\
\hline 100.0 & & & 18 & & & & & & & & & & & & 23 & & & & 7 & 42 & 1 & & & 9 & 1120 & & \\
\hline 120.1 & & & 5 & & 2 & & & & & & & & & & 6 & & & & & 56 & 3 & 13 & & 18 & 310 & & \\
\hline 140.6 & & & 10 & & $<1$ & & 39 & & & & & & & $<1$ & 3 & & & & 16 & 22 & & & & 9 & 1774 & & \\
\hline 163.0 & & 18 & 1 & & 18 & & 12 & & 6 & & & 2 & & & & 19 & & 11 & & & & & & 13 & 182 & \multirow{7}{*}{ '동 } & \multirow{7}{*}{ 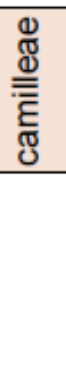 } \\
\hline 180.4 & & & & 1 & 28 & 7 & 20 & & & & & & 6 & 2 & & 10 & 1 & 1 & & & & & & 24 & 190 & & \\
\hline 201.2 & & & & 1 & 68 & 6 & 1 & 1 & 1 & & & & & & & 8 & 7 & & & & & & & 7 & 220 & & \\
\hline 221.2 & & & & 1 & 60 & 5 & 16 & 5 & & 1 & & & 2 & 2 & & & & & & & & & & 7 & 190 & & \\
\hline 240.7 & 5 & 1 & & & 16 & 3 & 22 & 5 & & 1 & & 16 & 3 & $<1$ & & & & & & & & & & 28 & 30 & & \\
\hline 261.2 & 16 & & & & 36 & 16 & 6 & & 2 & 3 & 2 & & & & & & & & & & & & & 19 & 1950 & & \\
\hline 269.0 & 58 & 2 & 13 & 1 & 7 & 1 & 4 & $<1$ & & & & & & & & & & & & & & & & 14 & 1466 & & \\
\hline
\end{tabular}

Figure 7 


\begin{tabular}{|c|c|c|c|c|c|c|c|c|c|c|c|c|c|c|c|c|c|c|c|c|c|c|c|c|c|c|c|c|c|c|c|c|c|c|c|}
\hline 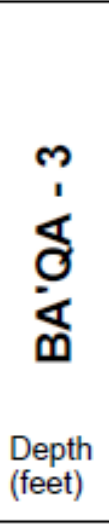 & 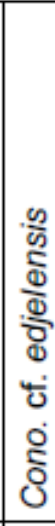 & 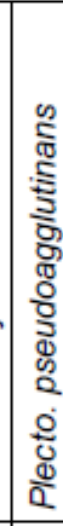 & 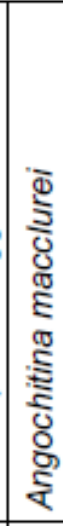 & 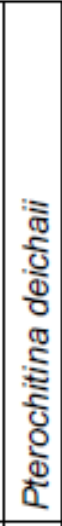 & 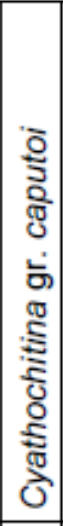 & 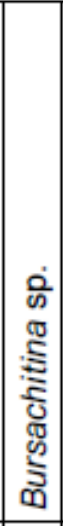 & 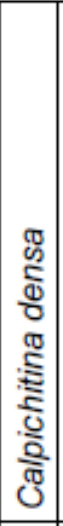 & 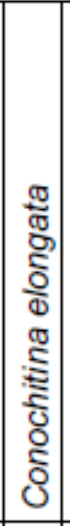 & 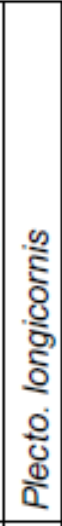 & 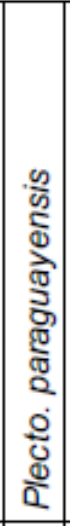 & 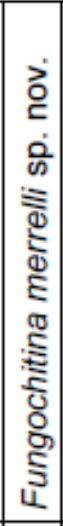 & 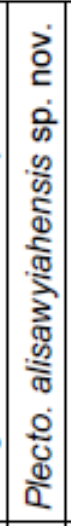 & 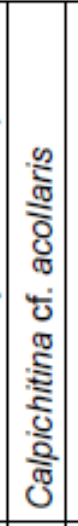 & 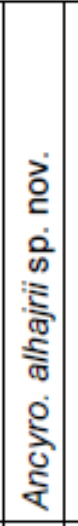 & 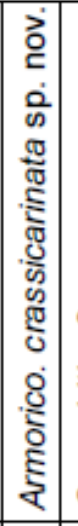 & 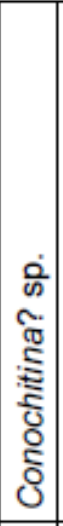 & 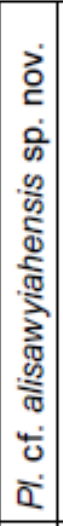 & 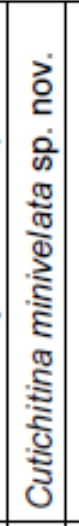 & 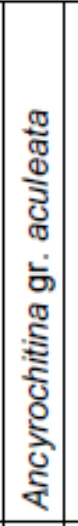 & 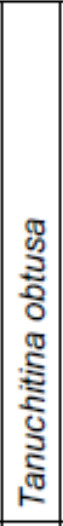 & 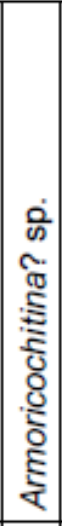 & 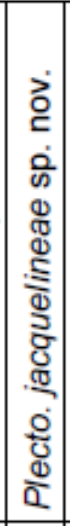 & 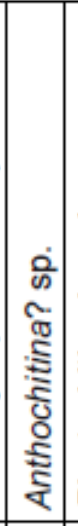 & 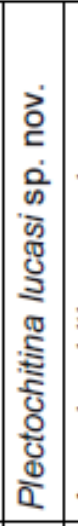 & 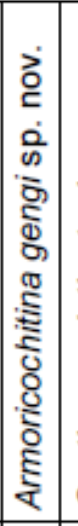 & 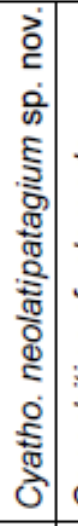 & 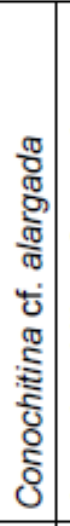 & 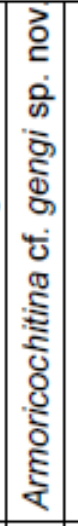 & 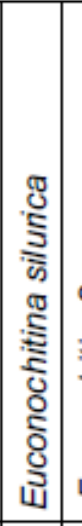 & 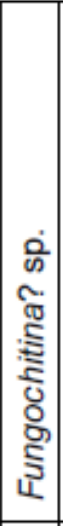 & 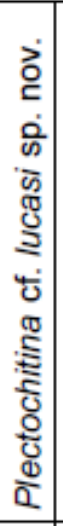 & 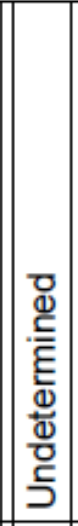 & 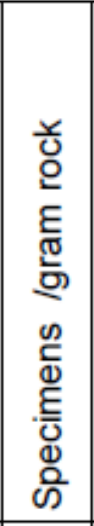 & 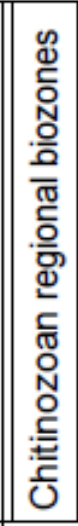 & 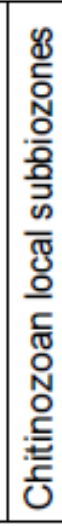 \\
\hline 130.0 & & & & & & & & & & & & & & & & & & & & & & & & & & & & & \begin{tabular}{|l|}
79 \\
\end{tabular} & 1 & 15 & 5 & 27 & & \\
\hline 150.4 & & & & & & & & & & & & 18 & 4 & & & & & & 7 & $<1$ & & & & & 42 & & $<1$ & 3 & \begin{tabular}{|l|}
5 \\
\end{tabular} & 1 & & 20 & 274 & .은 & \\
\hline 170.9 & & 10 & & 5 & & & & & & & & & 9 & & & & & & & & & & & & & & & 6 & \begin{tabular}{l|l}
4 \\
\end{tabular} & 51 & & 15 & 240 & 르 & \\
\hline 192.5 & & 3 & & & & & & & & & & 4 & 23 & & & & & 62 & & & & & & & & & & \begin{tabular}{|l|} 
\\
\end{tabular} & 2 & & & 5 & 51 & "ब & \\
\hline 206.9 & & 4 & & 11 & & & & & & 1 & & $<1$ & & & & & & & & 9 & & & & & & 39 & \begin{tabular}{l|l}
3 \\
\end{tabular} & & & & & 34 & 57 & & \\
\hline 229.7 & $<1$ & 48 & & 14 & & & & 2 & & 11 & & & 6 & & & & & & 1 & & & & & & & 1 & & & & & & 17 & \begin{tabular}{|l|}
1038 \\
\end{tabular} & & \\
\hline 250.5 & 5 & & $<1$ & 15 & & & & & 20 & 15 & & 1 & 2 & & & & $<1$ & & 3 & 5 & & & & 3 & 3 & & & & & & & $30 \mid$ & 410 & W & $\bar{\omega}$ \\
\hline 271.8 & & & & 1 & & & & & & & & & & & & & 7 & 2 & & & & & 6 & 63 & & & & & & & & 21 & 602 & 롱 & है \\
\hline 289.1 & & & & 5 & & & & & & & & & & & & & \begin{tabular}{|l|}
8 \\
\end{tabular} & 15 & 9 & 2 & & & \begin{tabular}{|l|}
10 \\
\end{tabular} & 10 & & & & & & & & 41 & 1840 & ठ० & \\
\hline 306.0 & & & 34 & 4 & 1 & & $<1$ & & & & & & & & & $<1$ & & \begin{tabular}{|l|}
37 \\
\end{tabular} & 4 & 1 & & 9 & & & & & & & & & & 10 & 1090 & & jac \\
\hline 330.4 & & & 73 & & & & $<1$ & & & & & 2 & & & 8 & & & \begin{tabular}{|l|}
2 \\
\end{tabular} & & 7 & 1 & & & & & & & & & & & 7 & \begin{tabular}{|r|}
85 \\
\end{tabular} & & 9 \\
\hline 350.1 & & & 48 & & $<1$ & & 3 & & & & & 2 & & & 24 & 2 & & 4 & 6 & 2 & 3 & & & & & & & & & & & 5 & 542 & & \\
\hline 370.4 & & & 46 & & & & 3 & & & 2 & & 14 & & & \begin{tabular}{|l|l} 
& 11 \\
\end{tabular} & $<1$ & 8 & 4 & 2 & & & & & & & & & & & & & 11 & 1230 & & . \\
\hline 388.0 & & & 14 & 8 & & & & & & 27 & & 14 & $\mid<1$ & \begin{tabular}{|l|}
27 \\
\end{tabular} & \begin{tabular}{|l|l|}
1 \\
\end{tabular} & & & & & & & & & & & & & & & & & \begin{tabular}{|l|}
9 \\
\end{tabular} & 424 & & 曲 \\
\hline 408.7 & & & 17 & 3 & & & & & & 5 & $<1$ & 3 & \begin{tabular}{|c|} 
\\
\end{tabular} & \begin{tabular}{|l|}
42 \\
\end{tabular} & \begin{tabular}{|l|l|}
12 \\
\end{tabular} & $<1$ & & & & & & & & & & & & & & & & 16 & 67 & $\overline{0}$ & 5 \\
\hline 431.7 & & & 48 & 6 & 1 & & & & & & 1 & \begin{tabular}{|l|}
4 \\
\end{tabular} & & \begin{tabular}{|l|l|}
30 \\
\end{tabular} & & & & & & & & & & & & & & & & & & 10 & 348 & ర్ర & 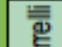 \\
\hline 450.1 & & & 10 & 14 & & & & & & & 5 & 55 & 5 & & & & & & & & & & & & & & & & & & & 11 & 94 & E & है \\
\hline 469.8 & 2 & & 13 & 3 & 2 & & & & & 73 & & & & & & & & & & & & & & & & & & & & & & 7 & 620 & & \\
\hline 490.3 & & 27 & 51 & \begin{tabular}{|l|}
11 \\
\end{tabular} & 3 & $<1$ & 4 & 1 & & & & & & & & & & & & & & & & & & & & & & & & 2 & 1680 & & \\
\hline 518.3 & $<1$ & 15 & 44 & 4 & $<1$ & \begin{tabular}{|l|}
7 \\
\end{tabular} & & & & & ? & 3 & $\mid<1$ & & & & & & & & & & & & & & & & & & & 25 & 1400 & & \\
\hline
\end{tabular}

Figure 8 


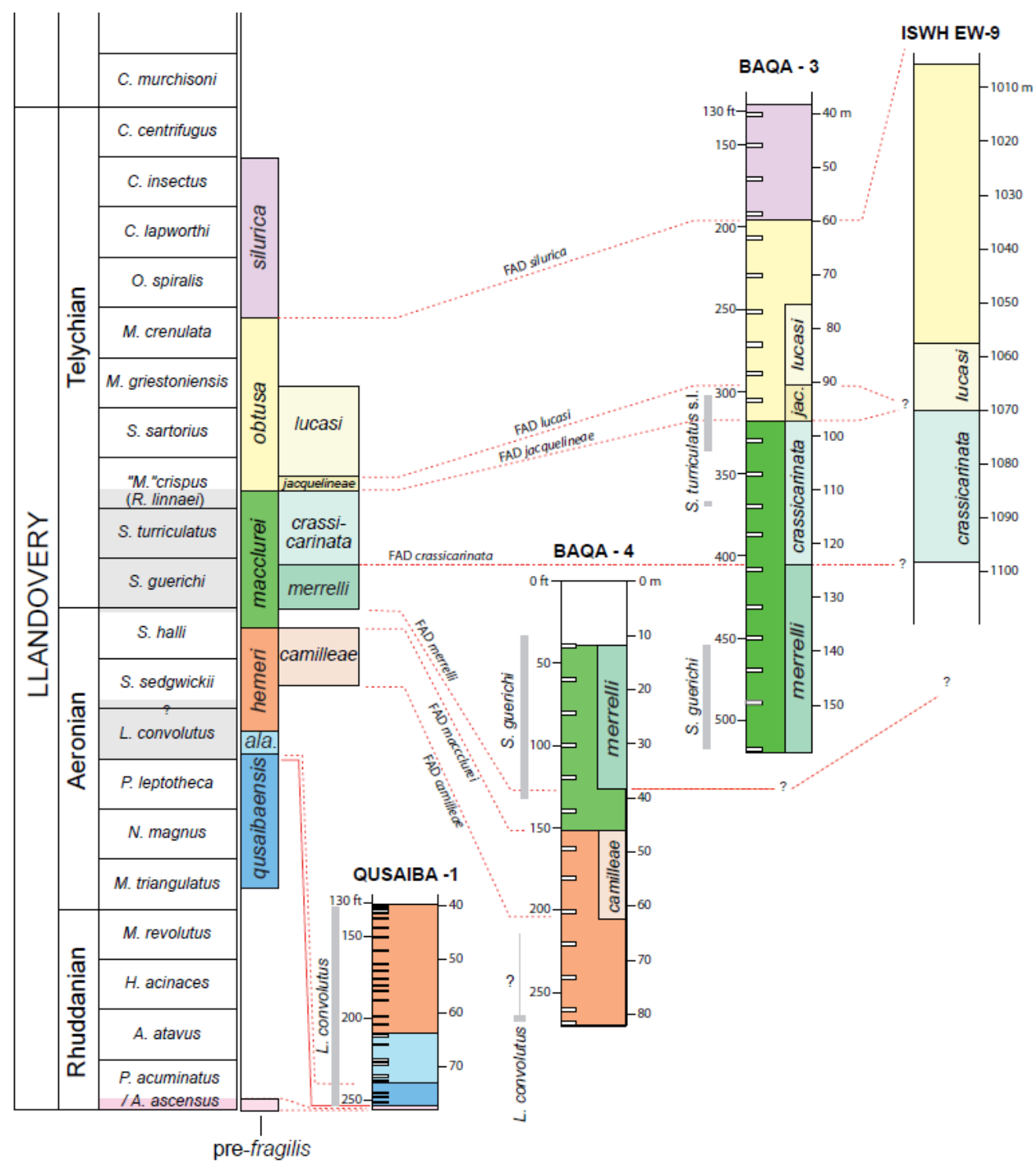

Figure 9 
$\mathrm{Dp} \mu \mathrm{m}$

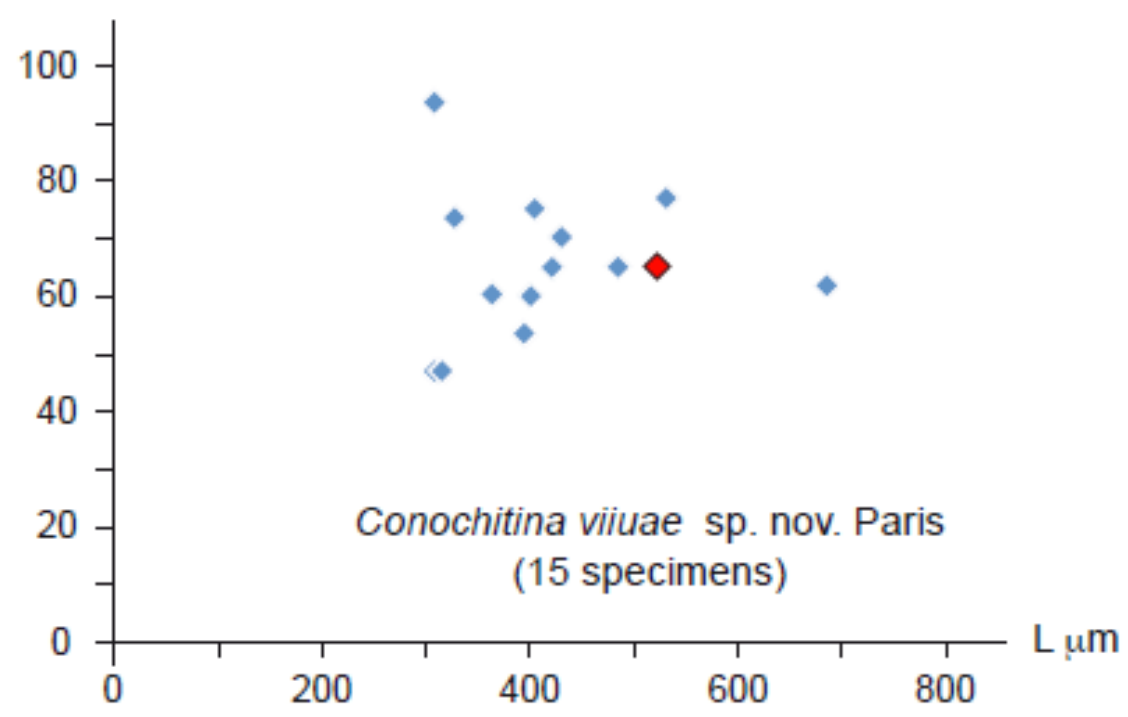

Dc $\mu \mathrm{m}$

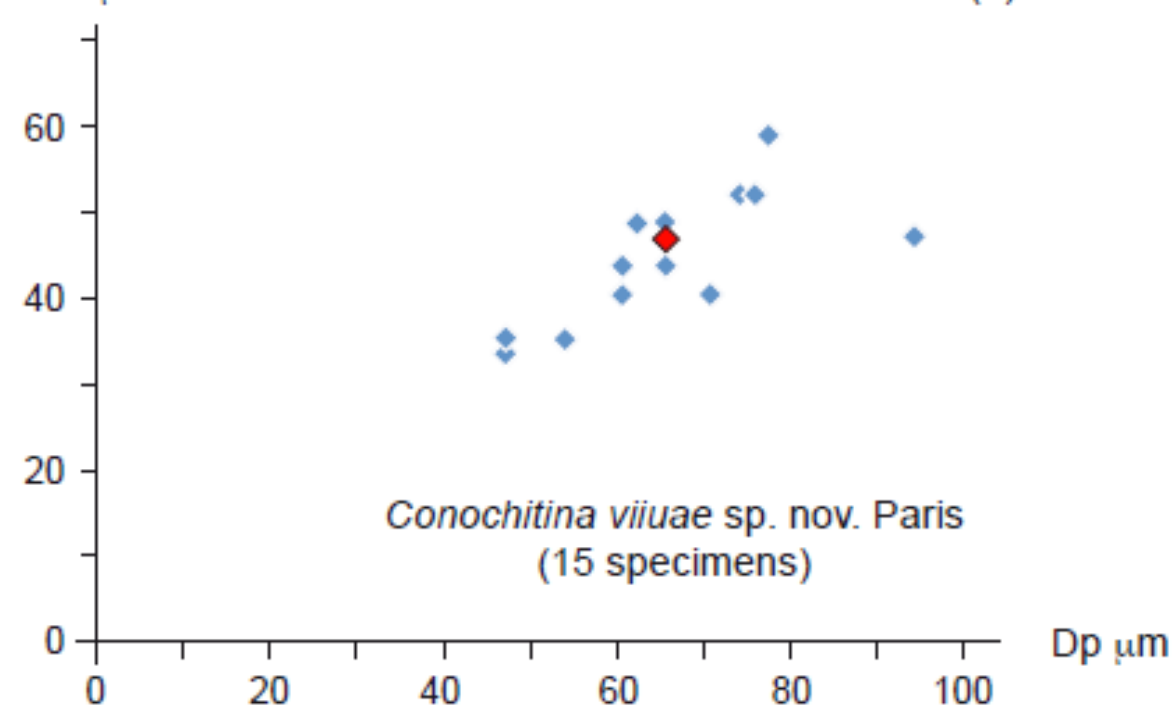

Figure 10 

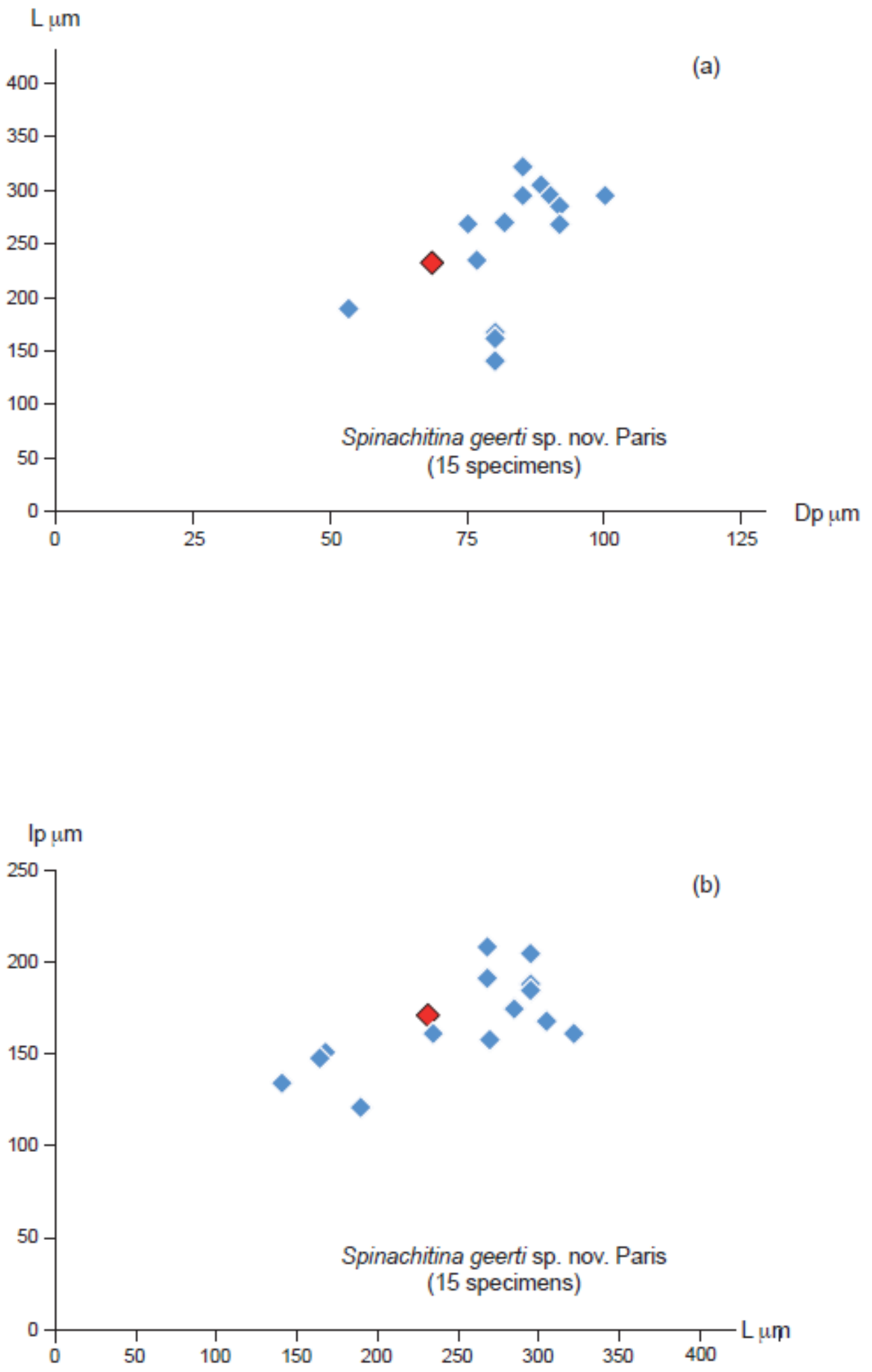

Figure 11 


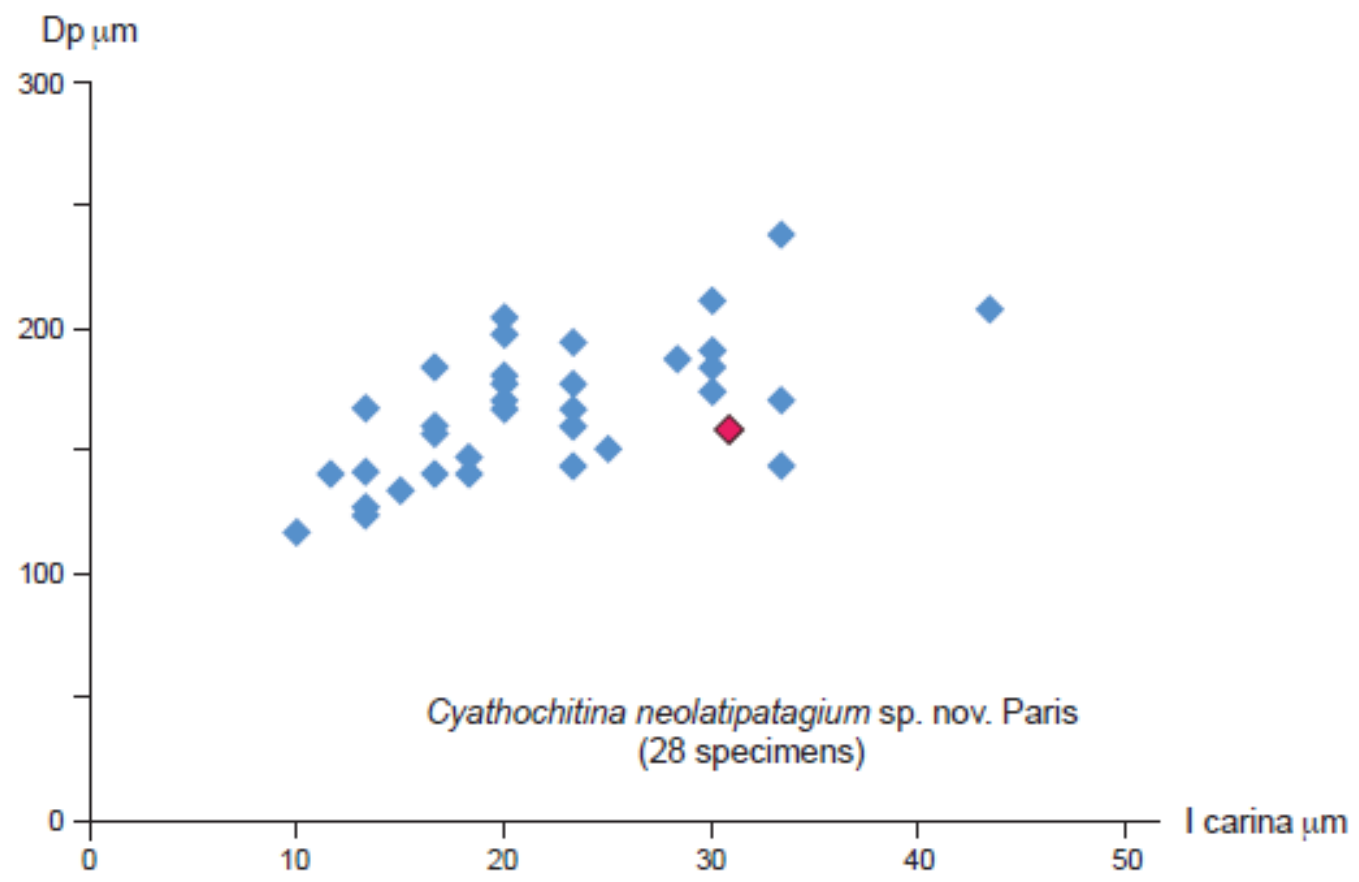

Figure 12 


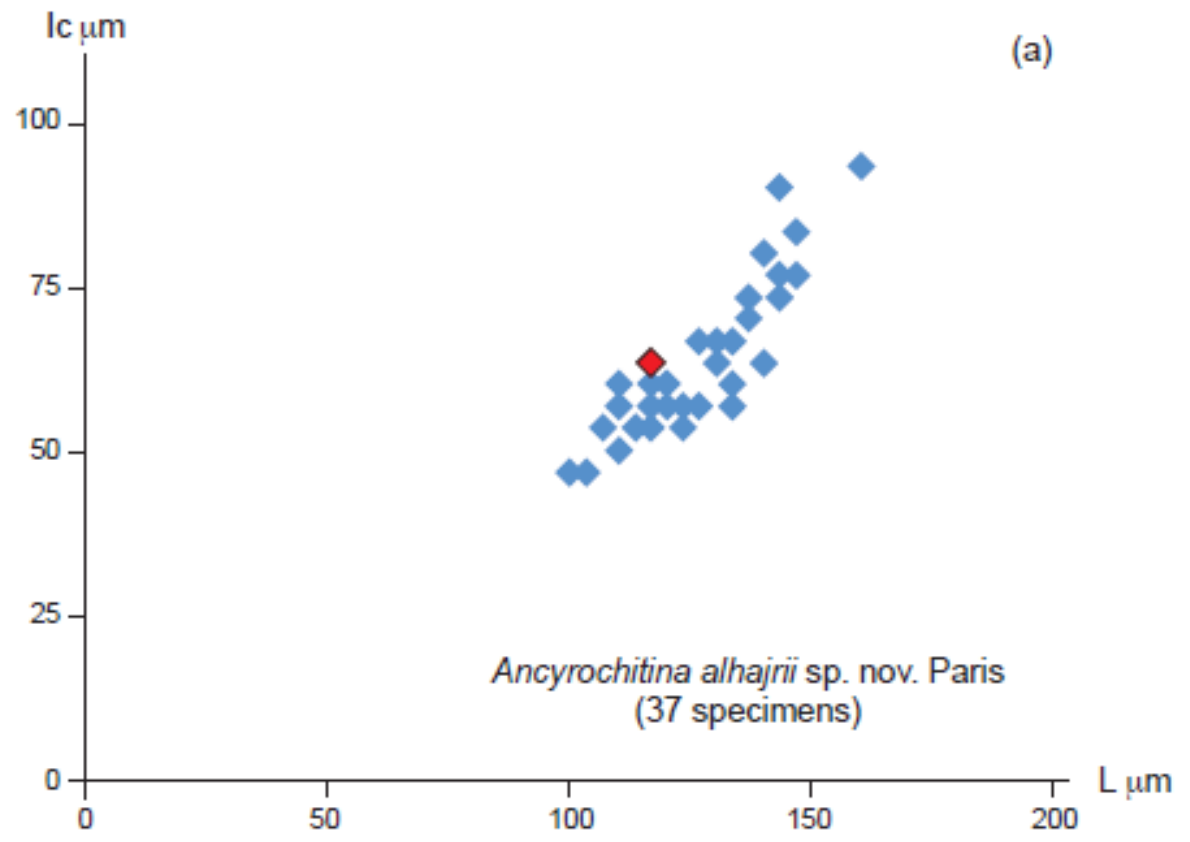

$\mathrm{L} \mu \mathrm{m}$

(b)

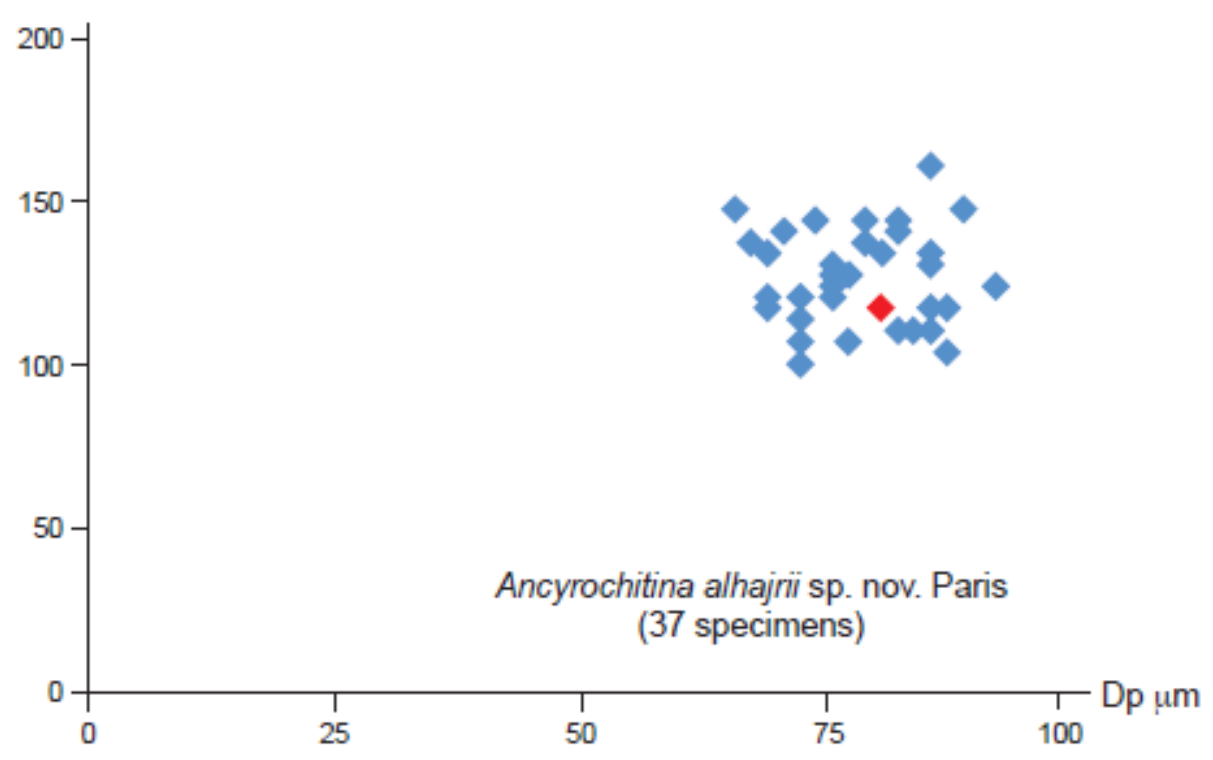

Figure 13 

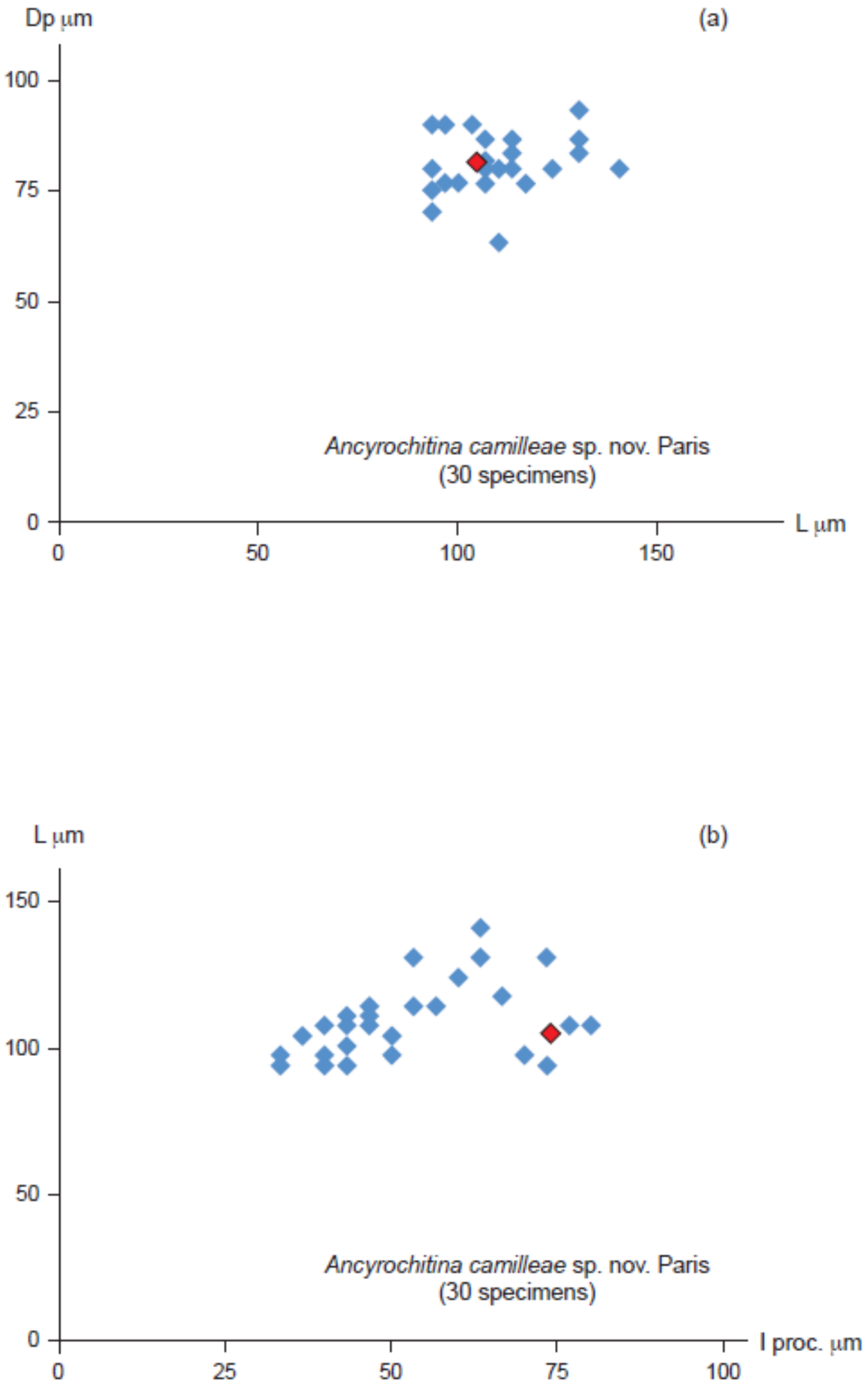

Figure 14 

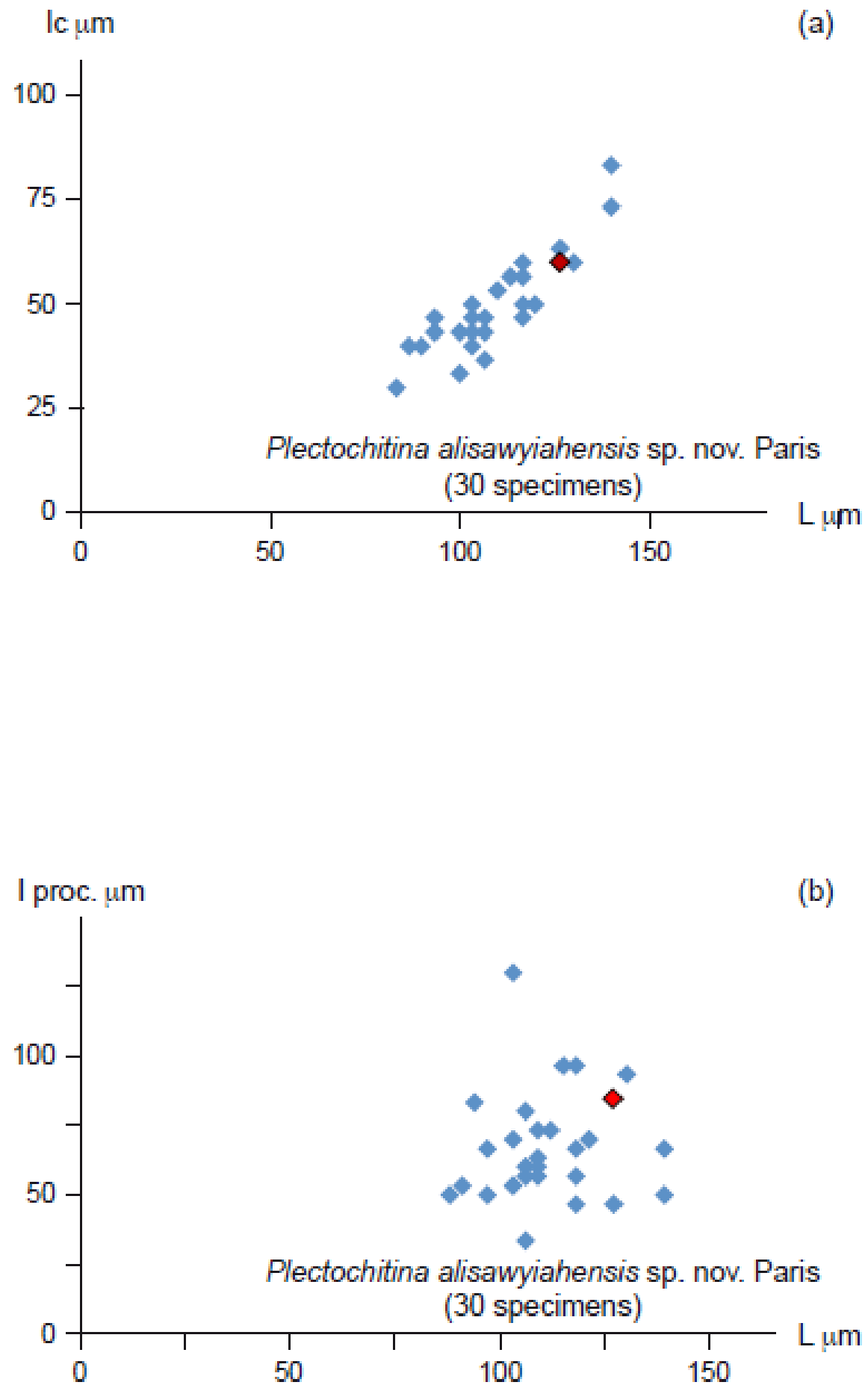

Figure 15 
L um

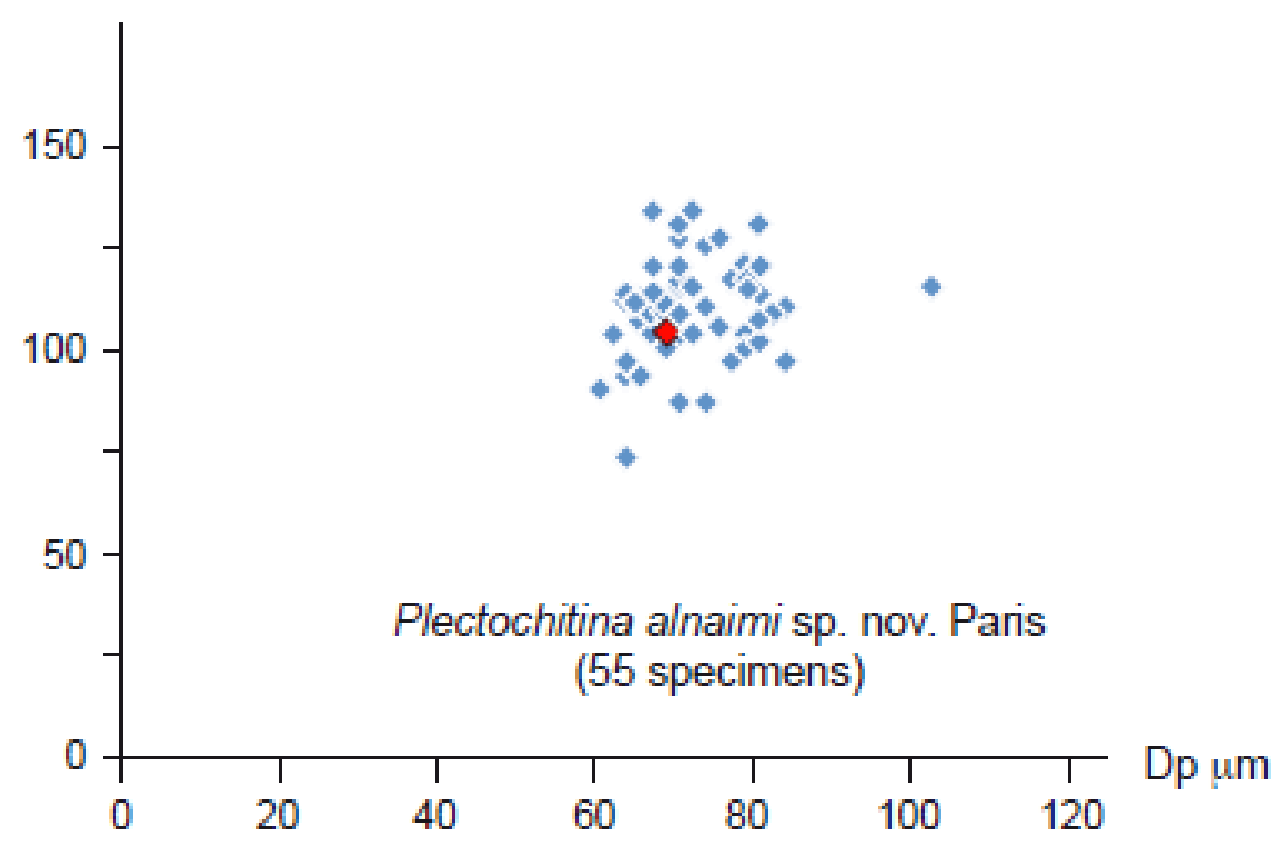

Ic um

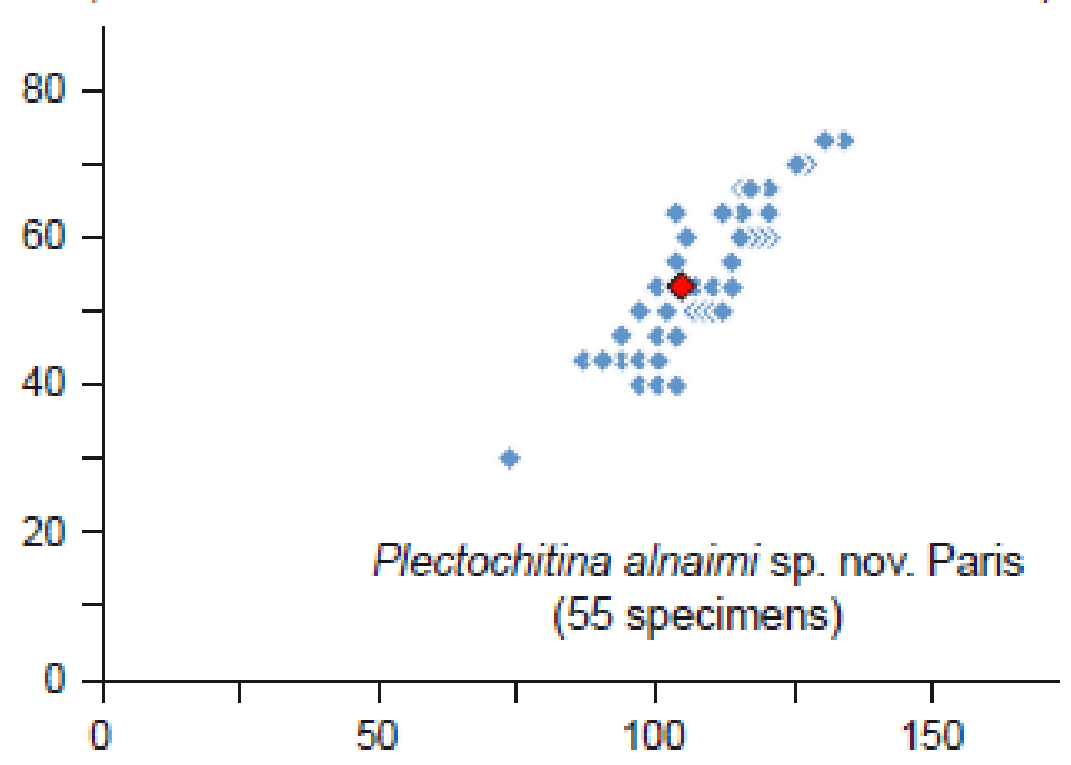

(b)

(a) 
Ic $\mu \mathrm{m}$

(a)

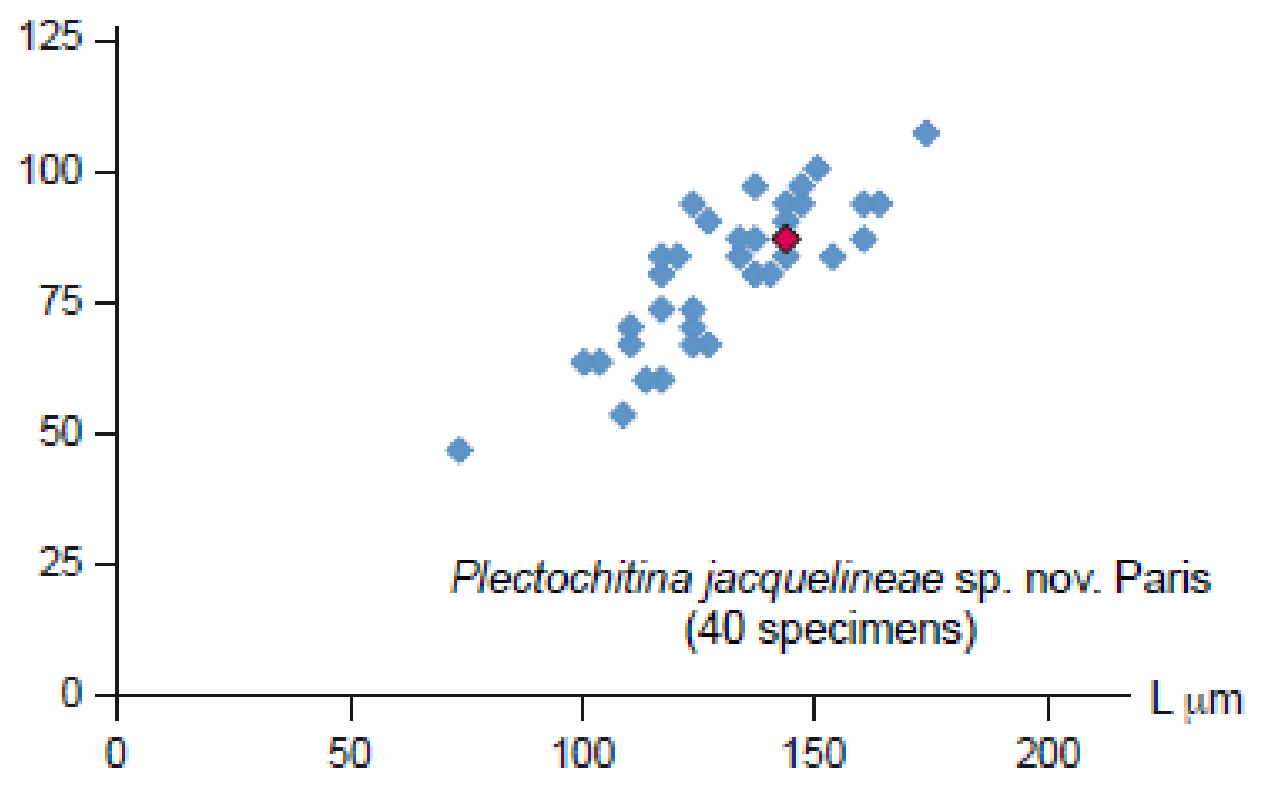

$\mathrm{L} \mu \mathrm{m}$

(b)

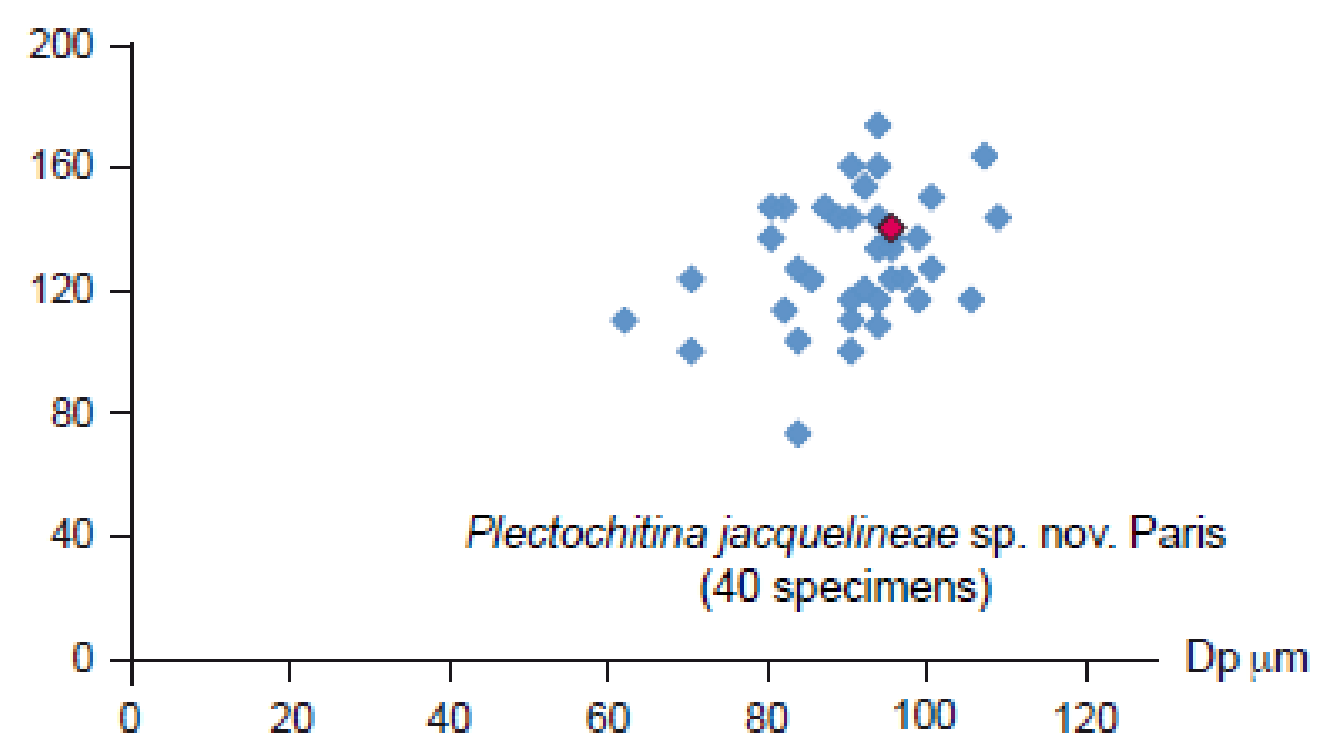

Figure 17 
$\mathrm{L} u \mathrm{~m}$

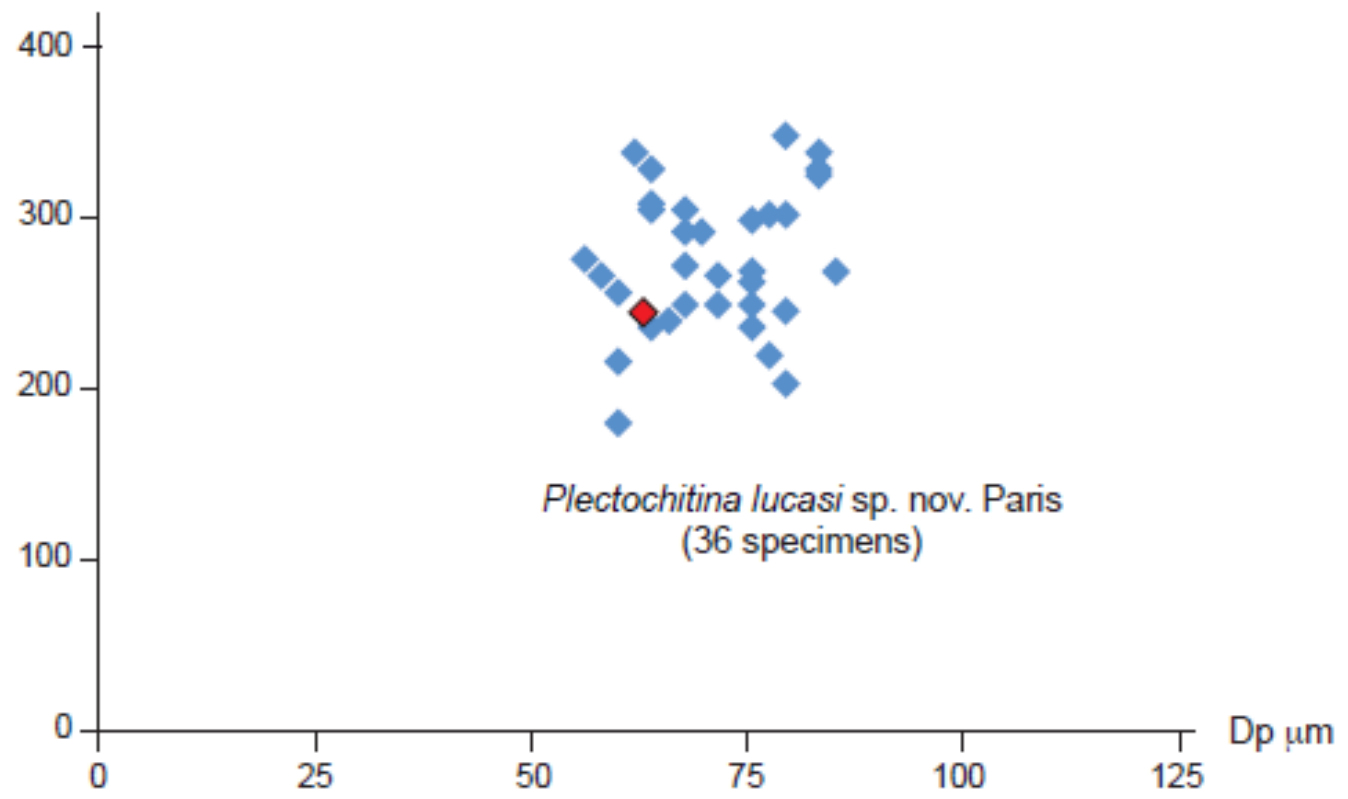

Ic $\mu \mathrm{m}$

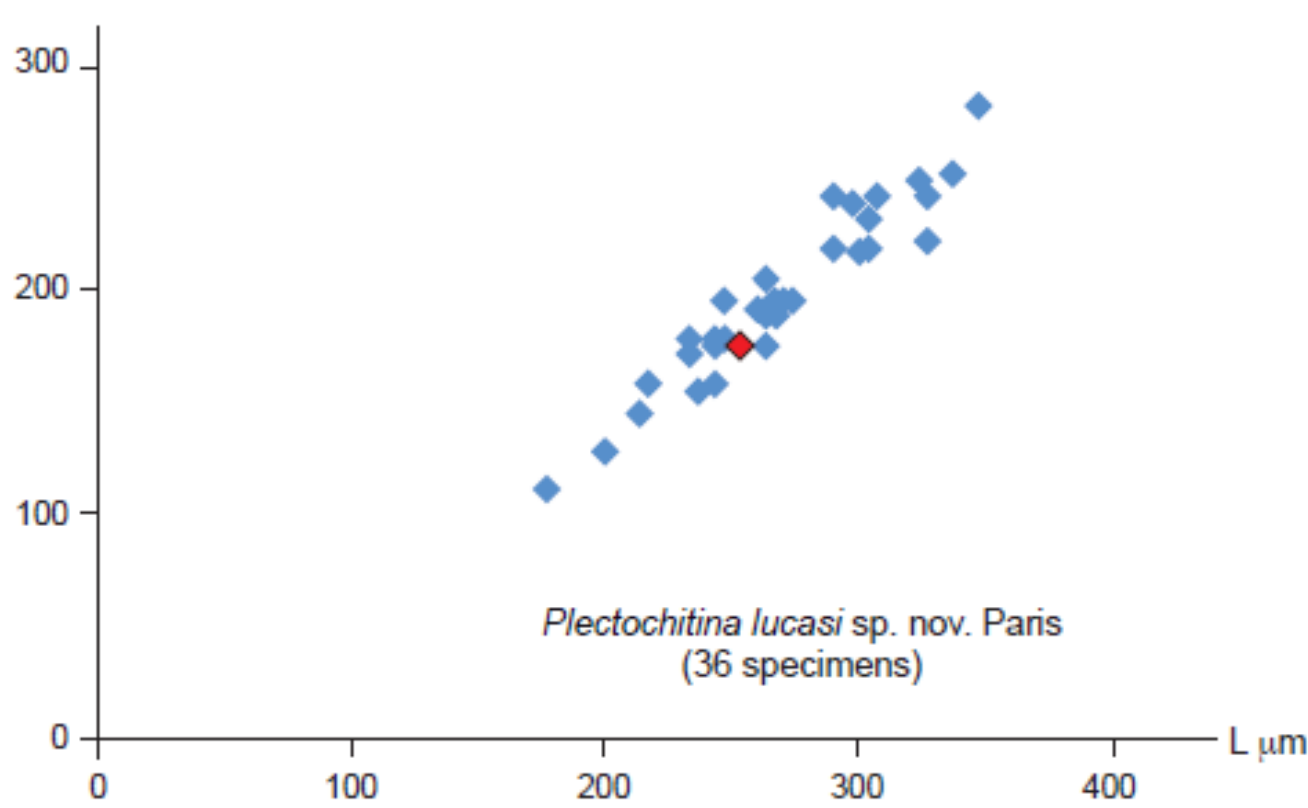

Figure 18 


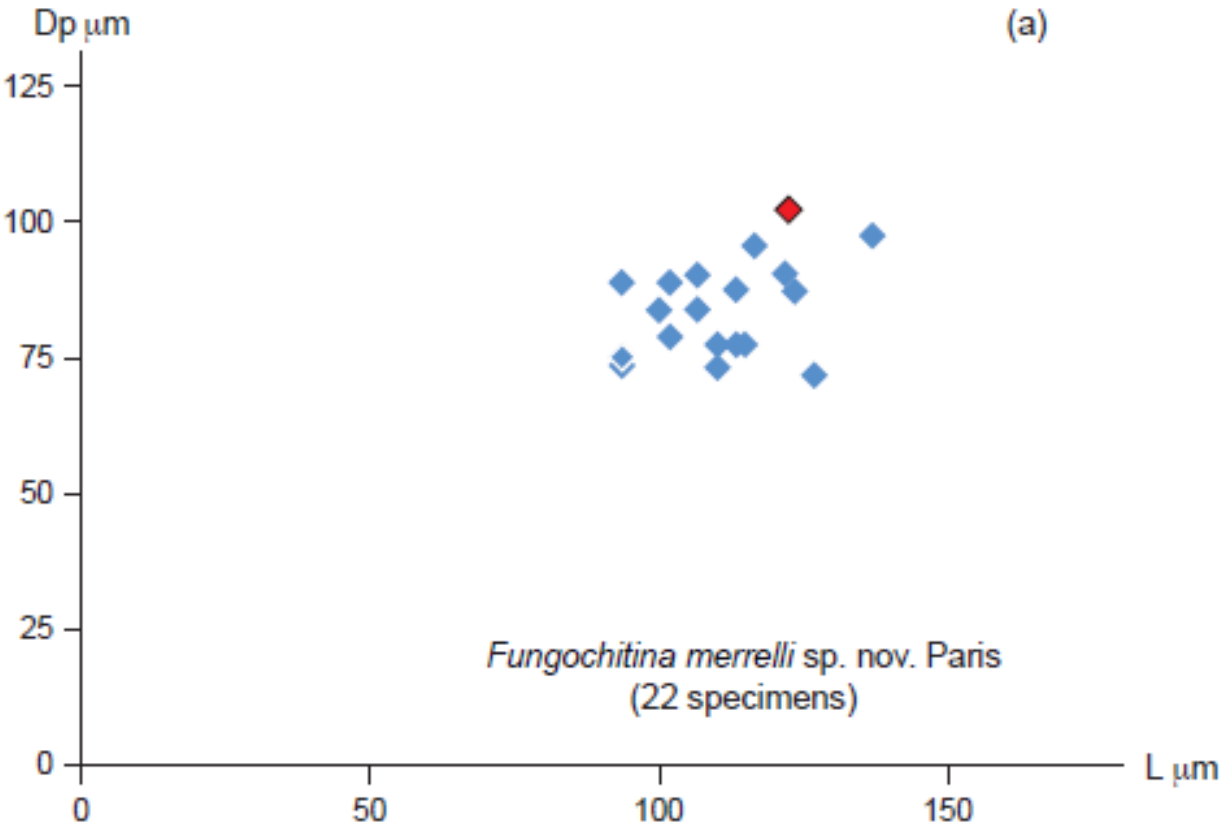

Ic $\mu \mathrm{m}$

(b)

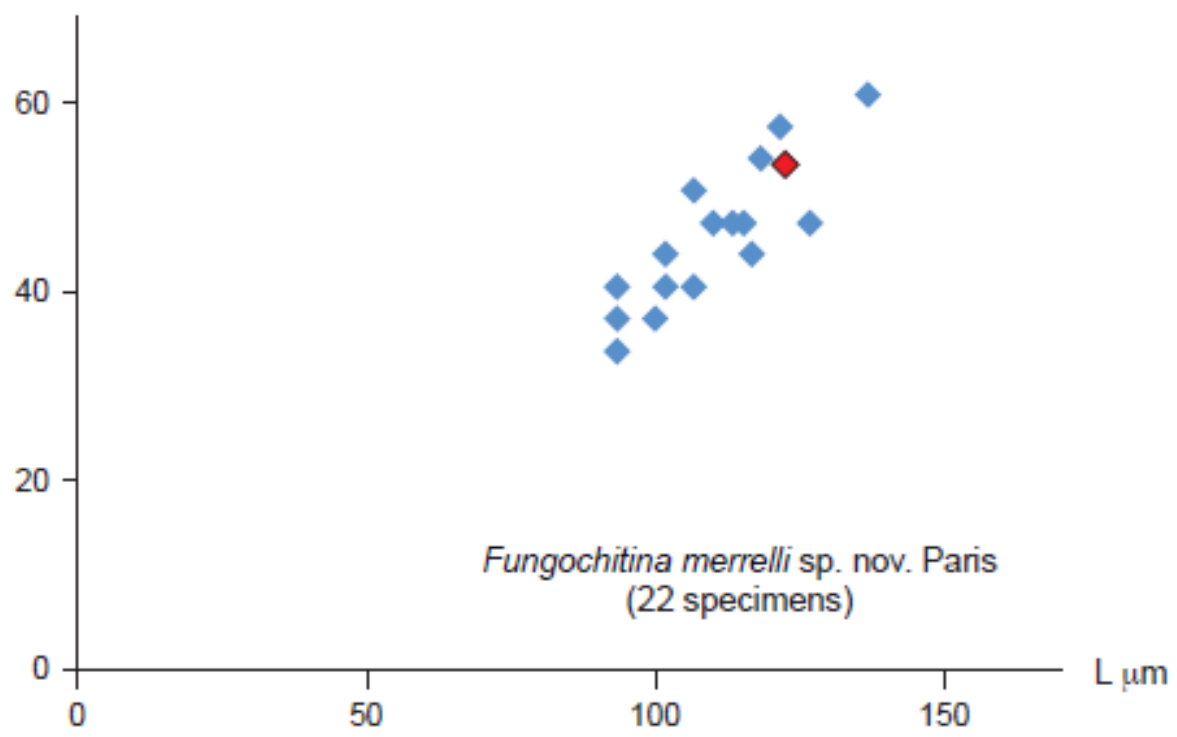

Figure 19 
$\mathrm{L} \mu \mathrm{m}$

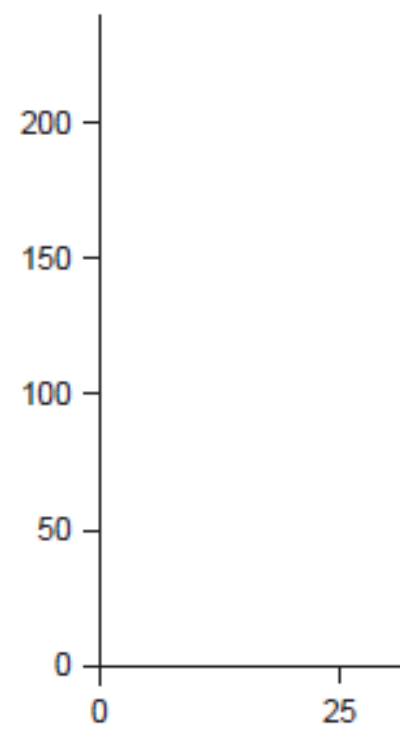

(a)
Ic $\mu \mathrm{m}$

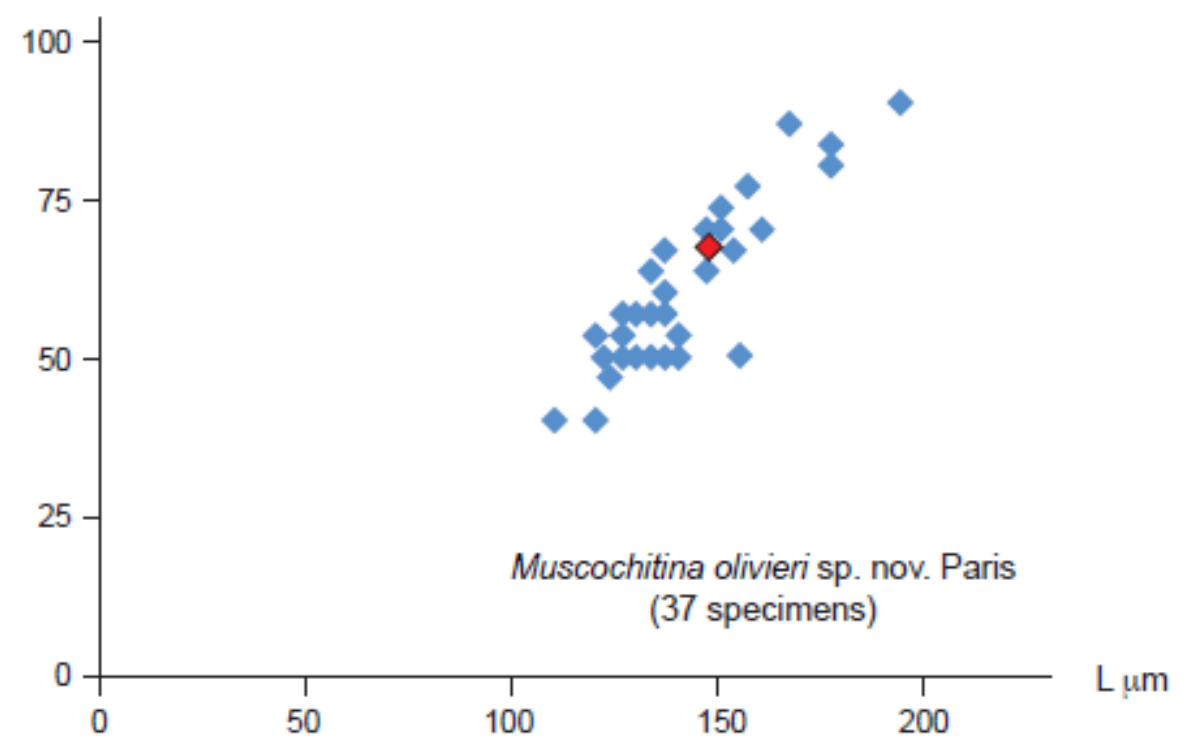

Figure 20

Muscochitina olivierisp. nov. Paris (37 specimens) 

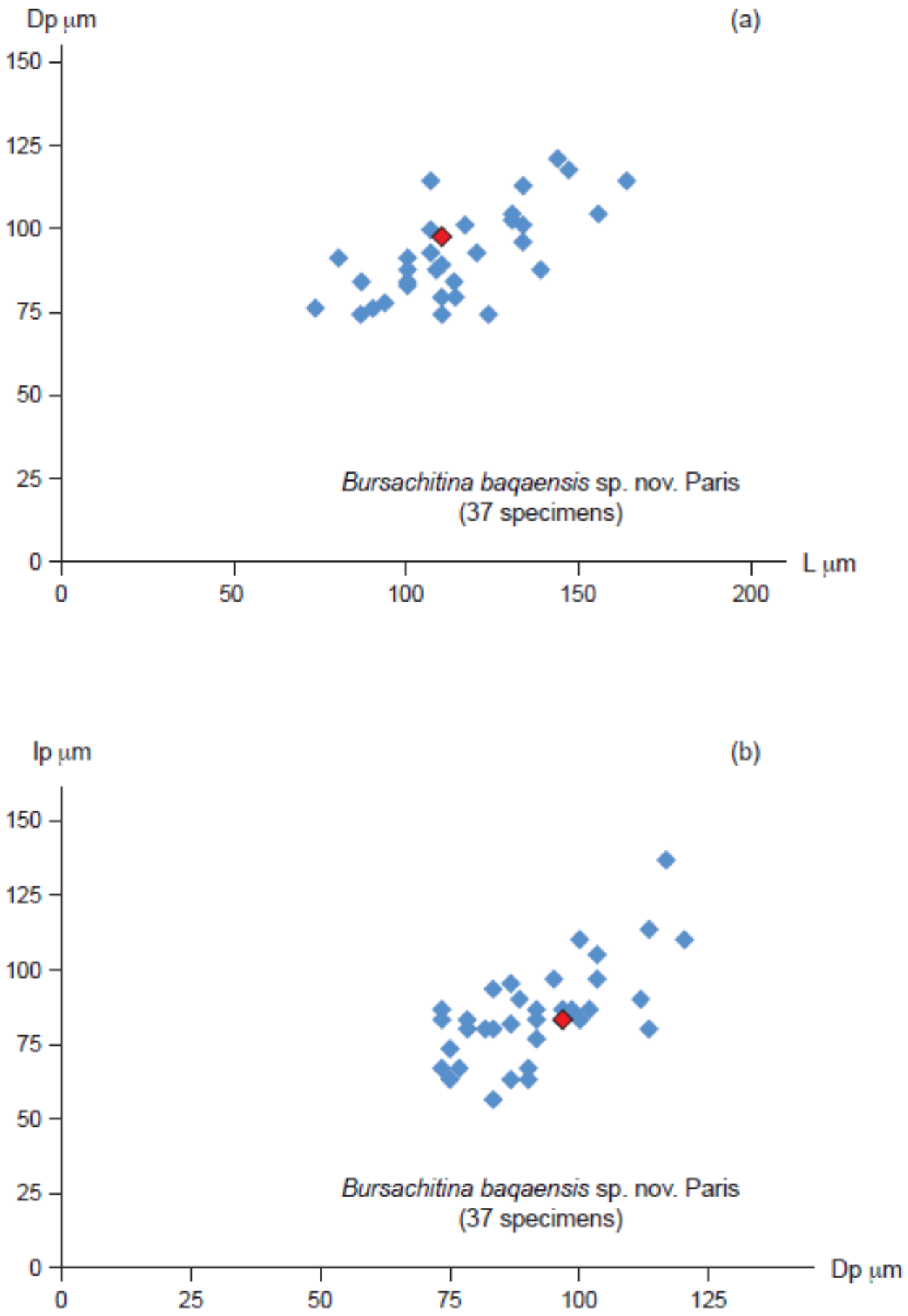

Figure 21 
$\mathrm{L} \mu \mathrm{m}$

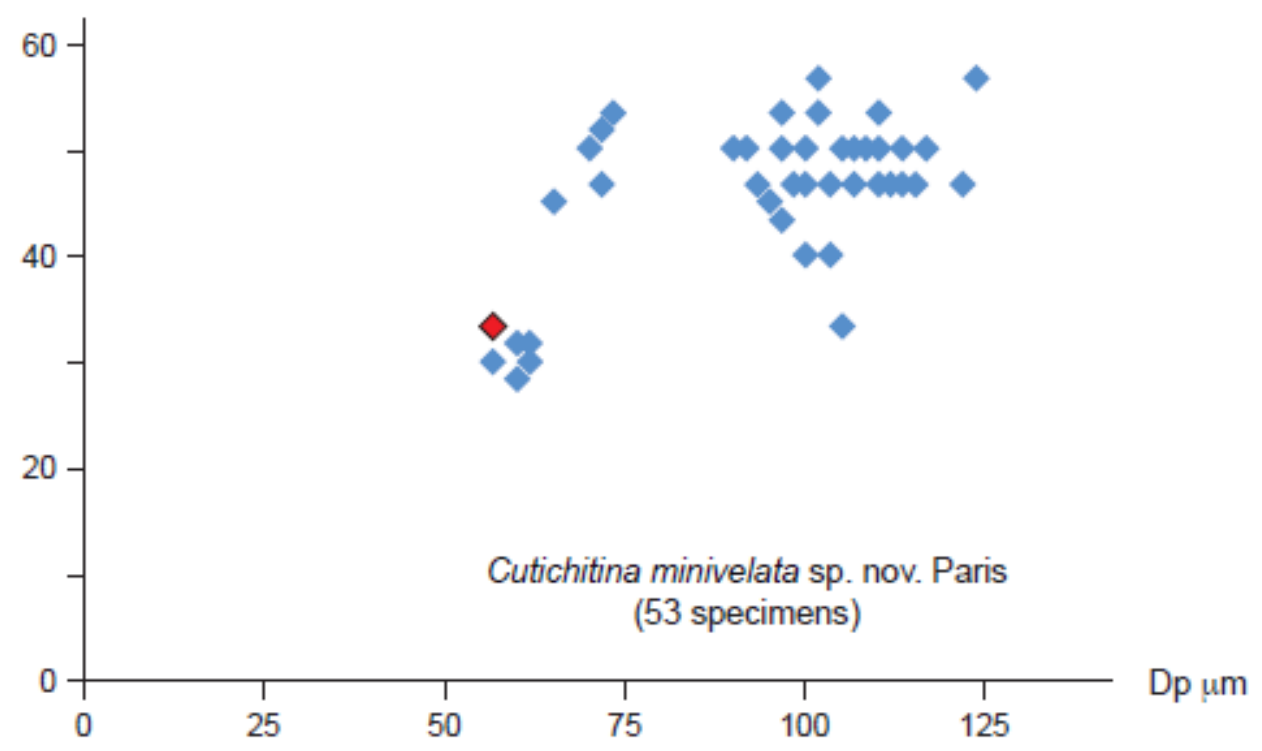

$\mathrm{L} \mu \mathrm{m}$

60

$60-$

$40-$

$-$

20

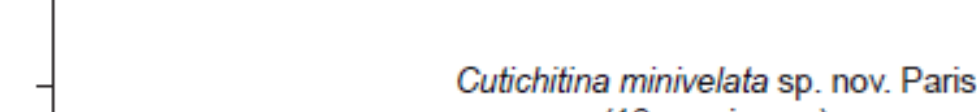

(18 specimens)

(b)

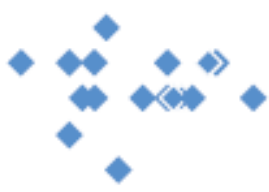

(a) 
$\mathrm{L} \mu \mathrm{m}$

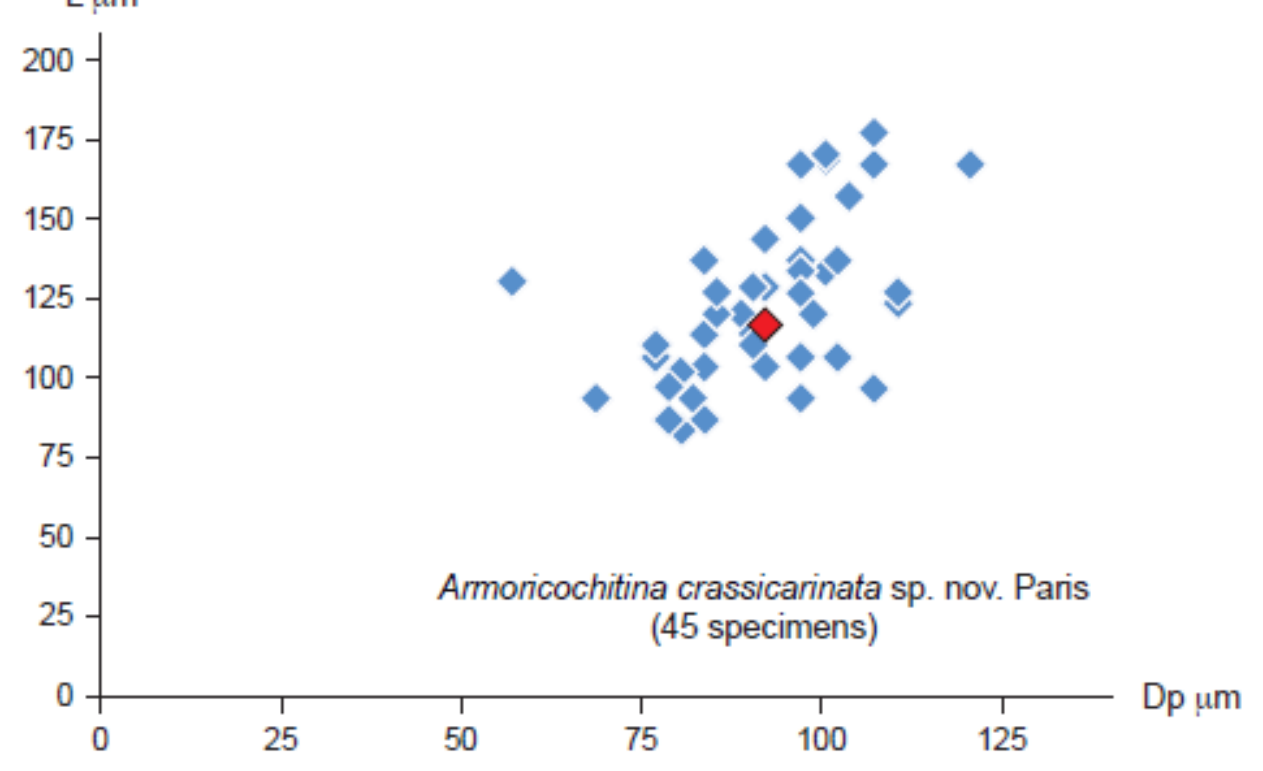

Icoll. $\mu \mathrm{m}$

(b)

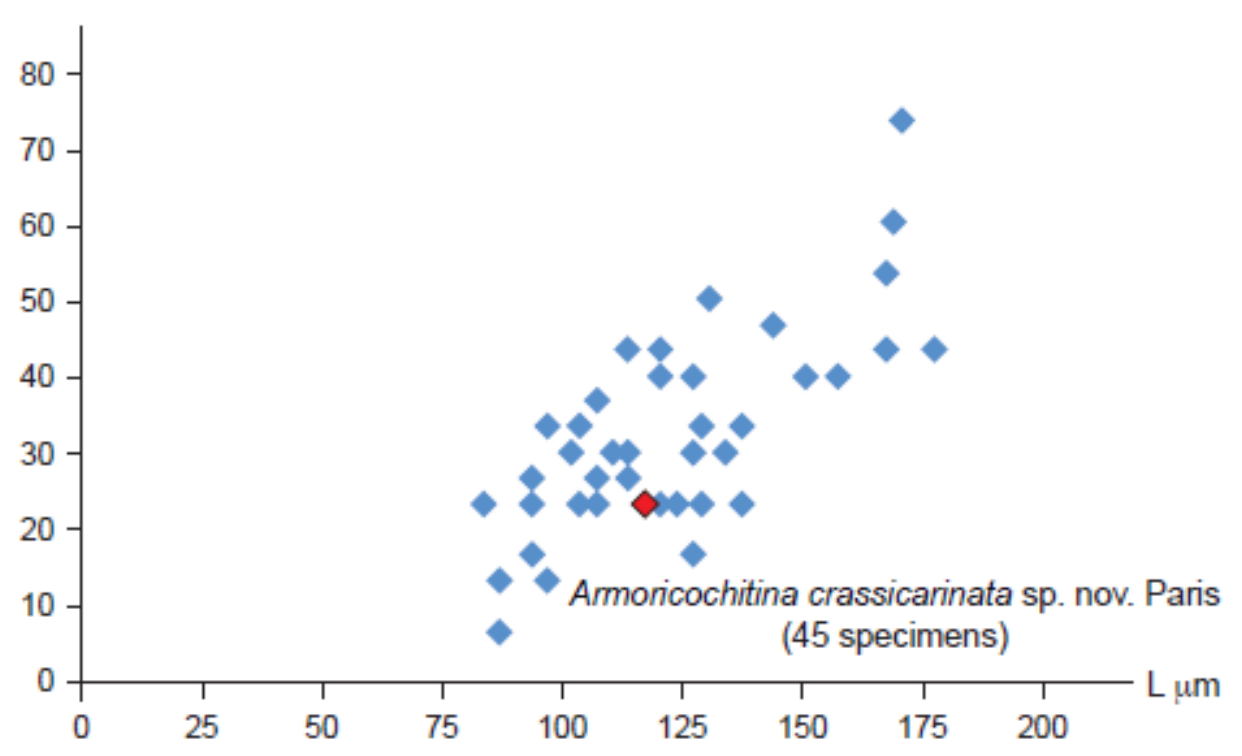

Figure 23 
$\mathrm{Dp} \mu \mathrm{m}$

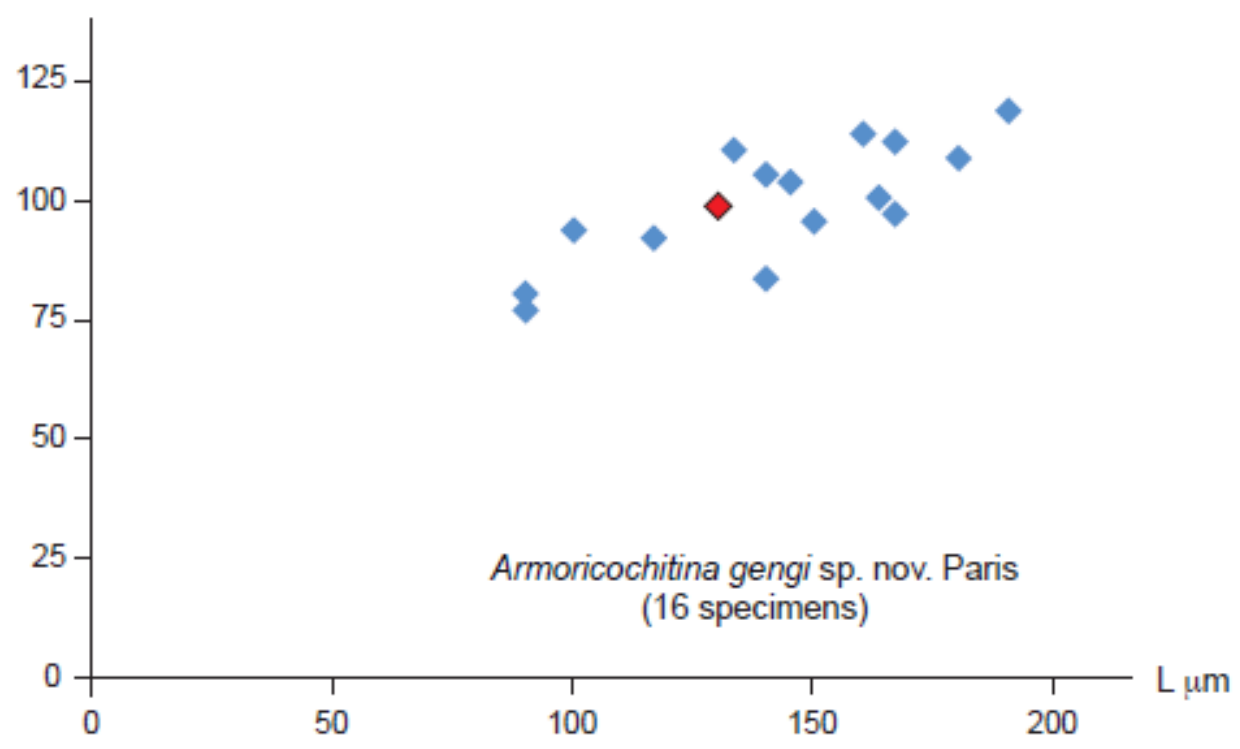

$\mathrm{L} u \mathrm{~m}$

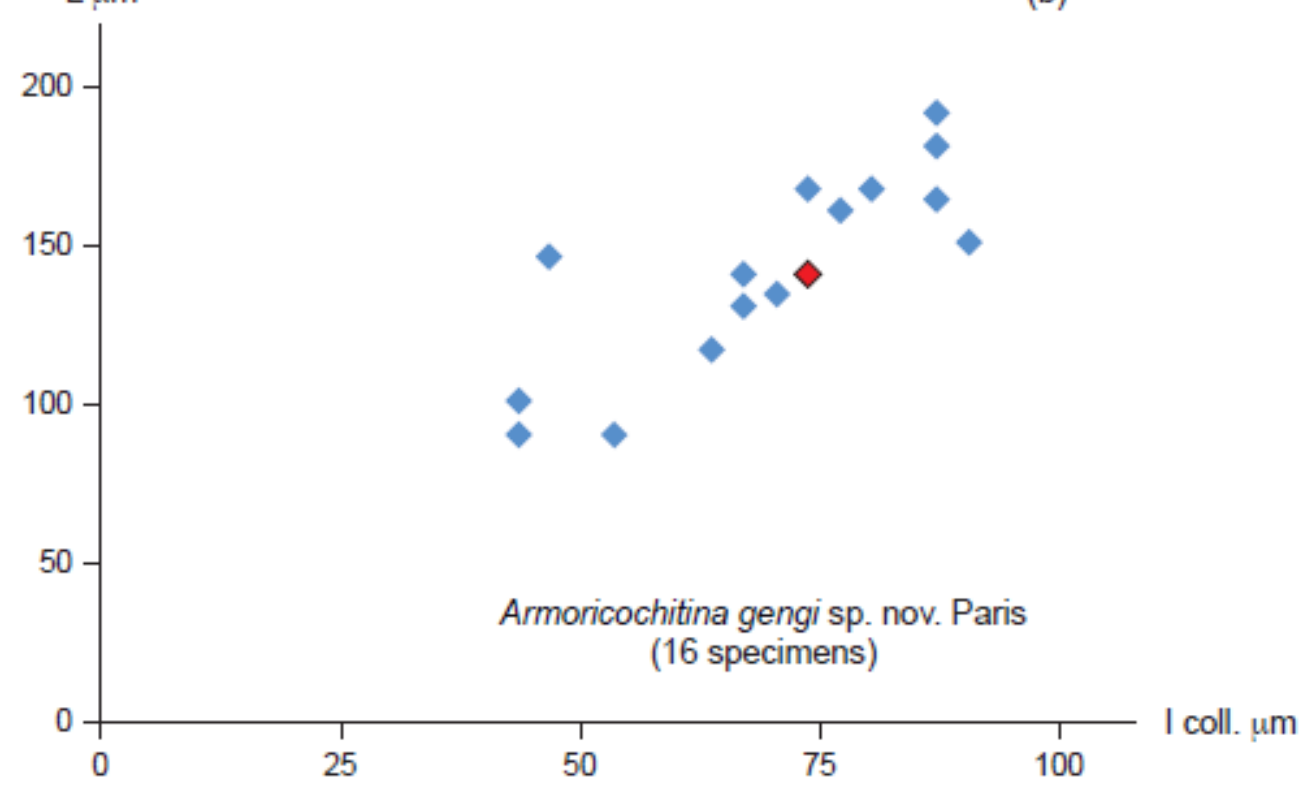

Figure 24 

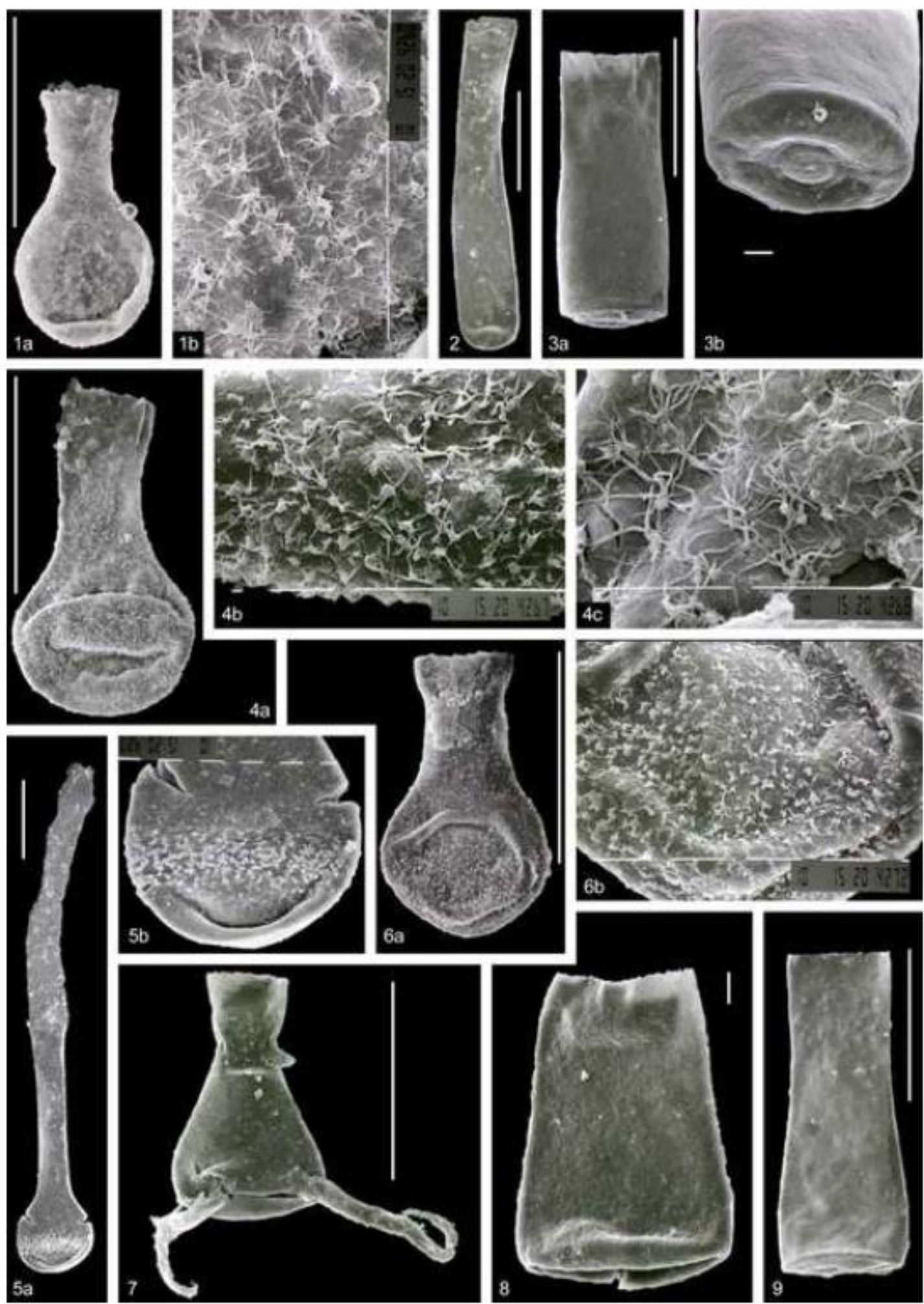

Plate I 

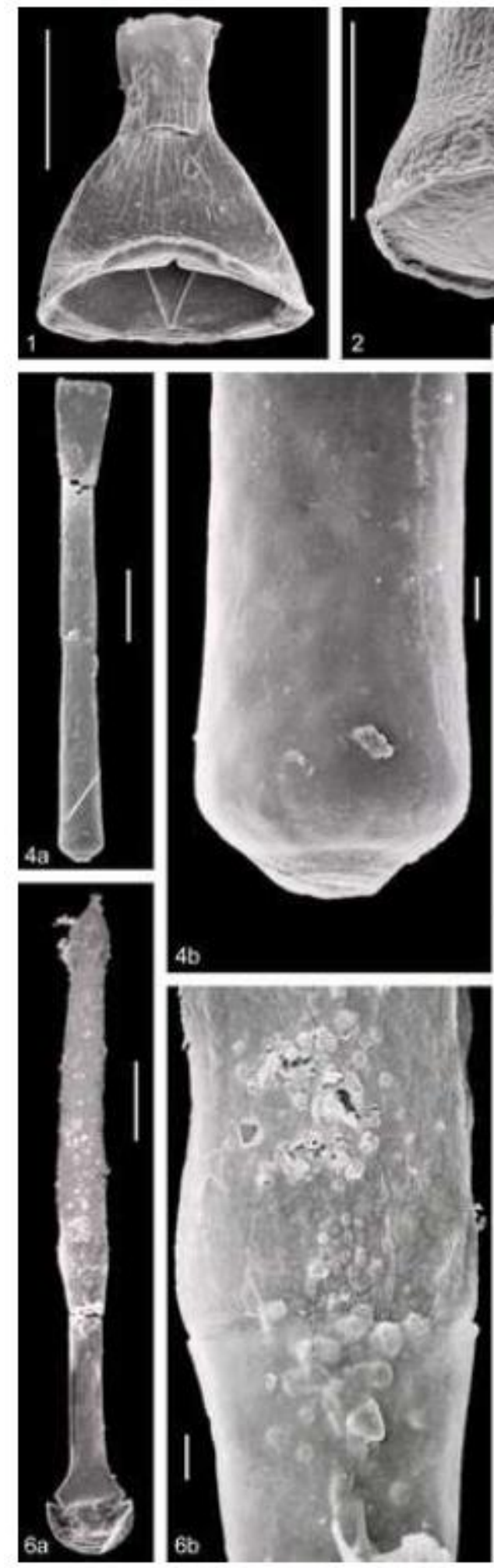
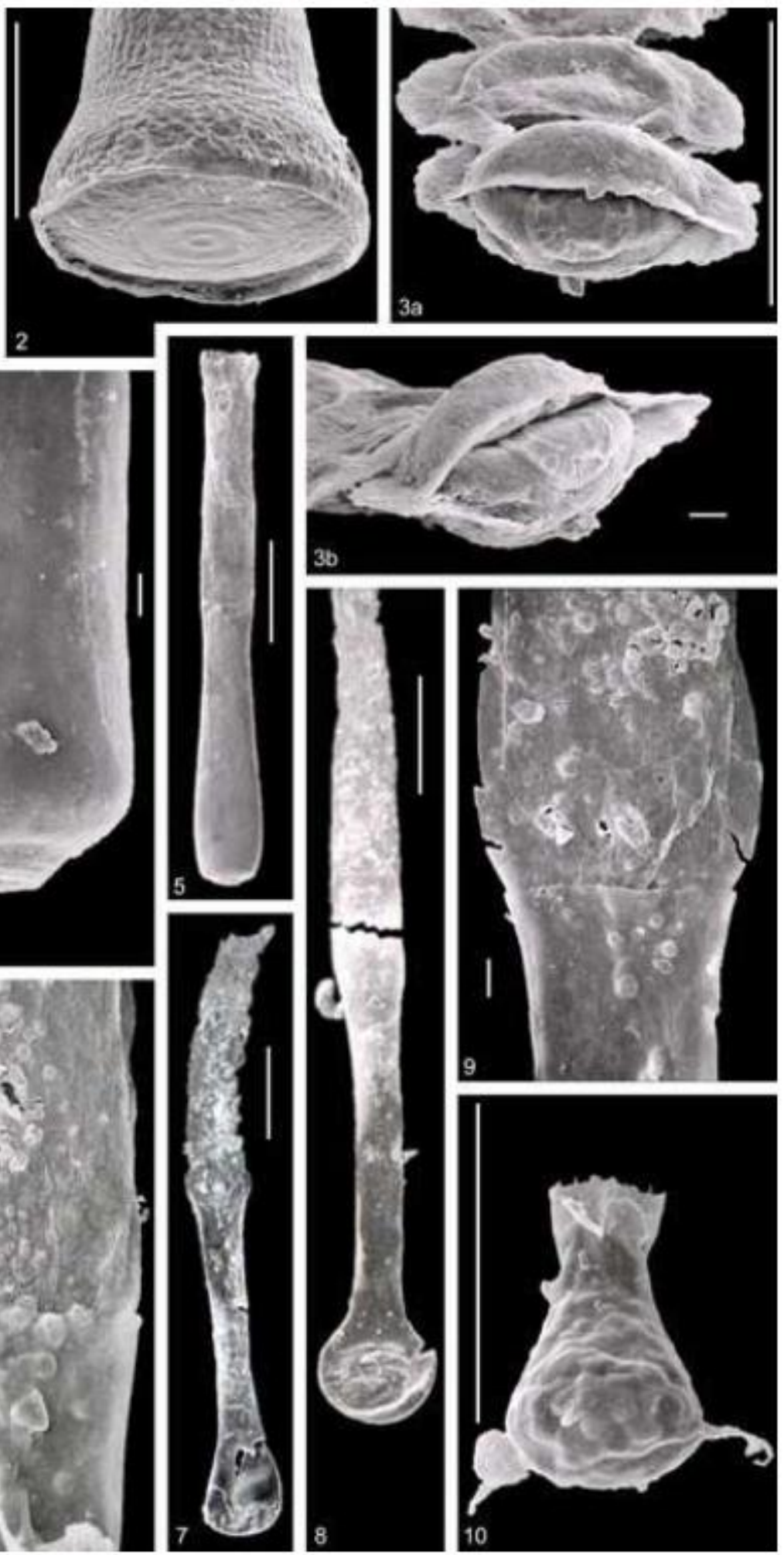

Plate II 

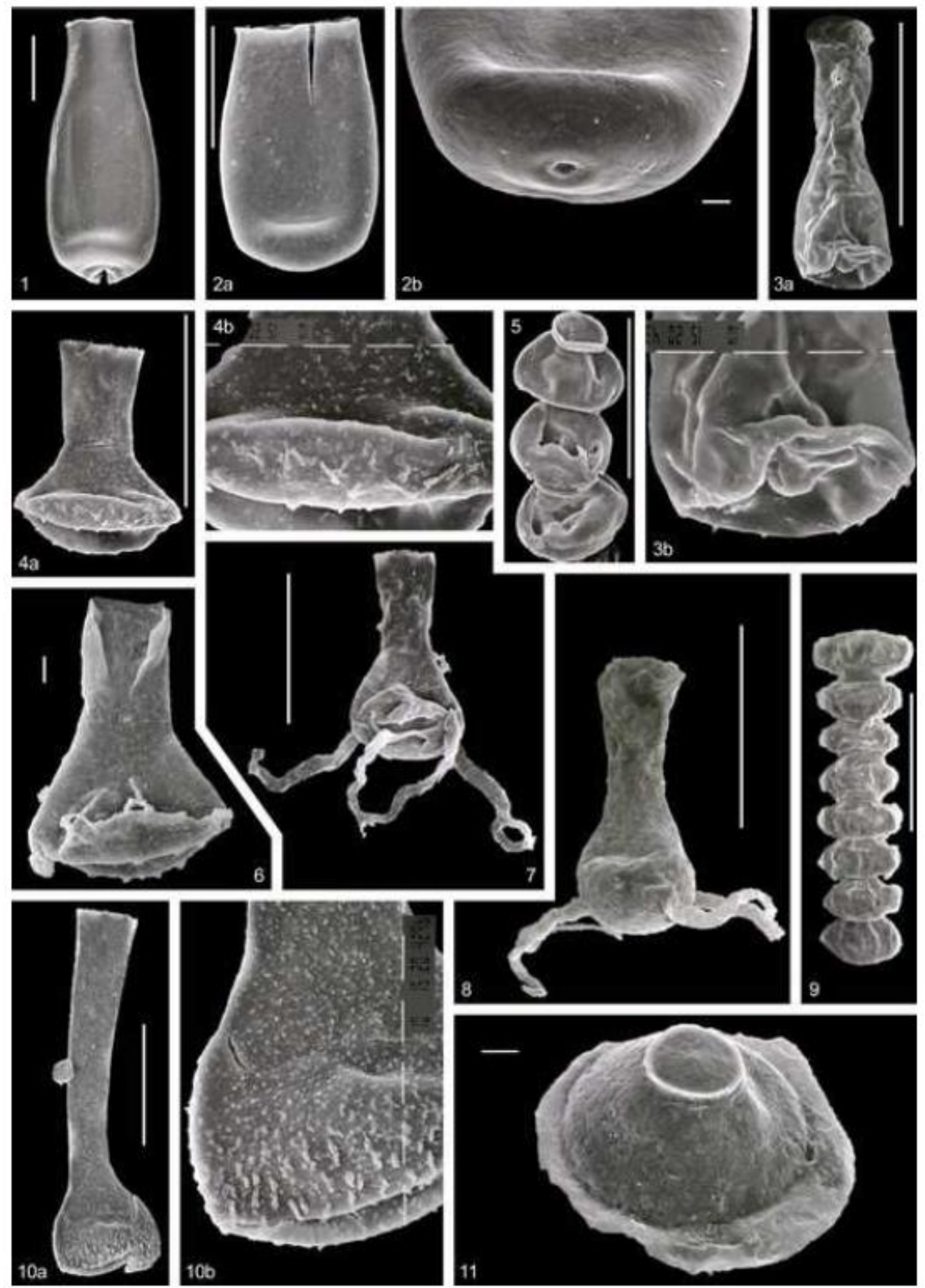

Plate III

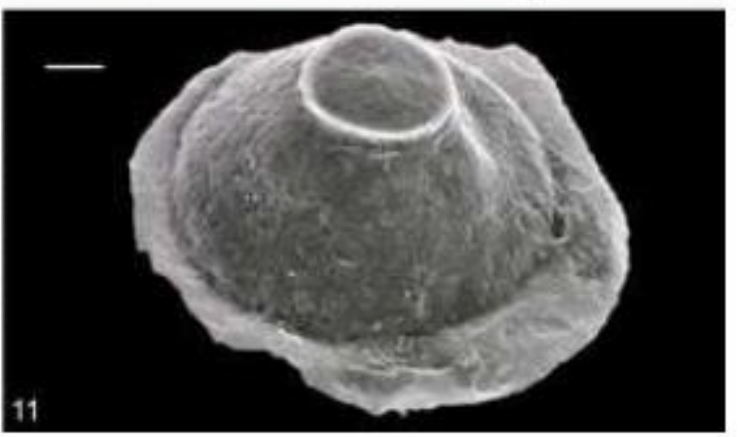



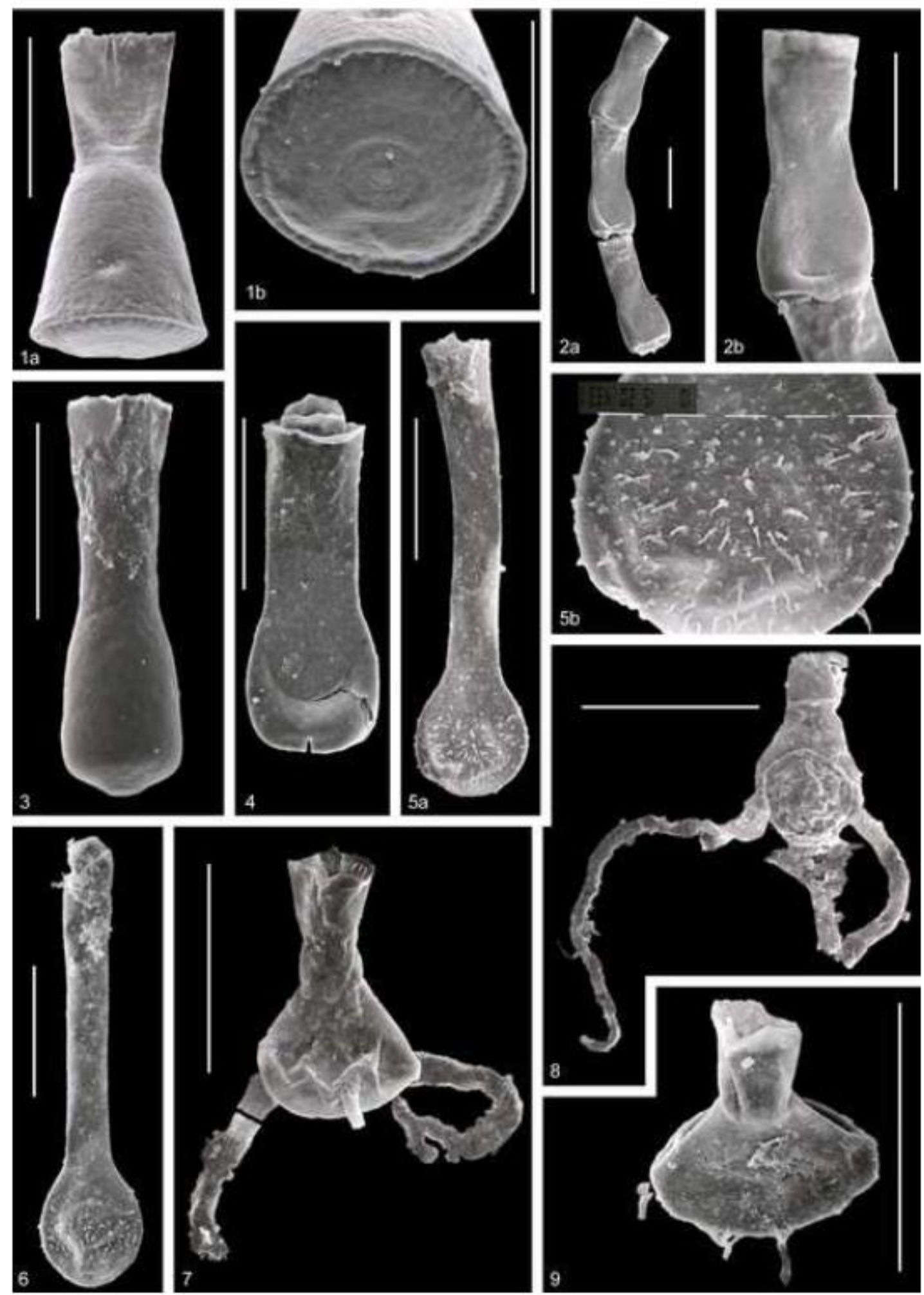

Plate IV 


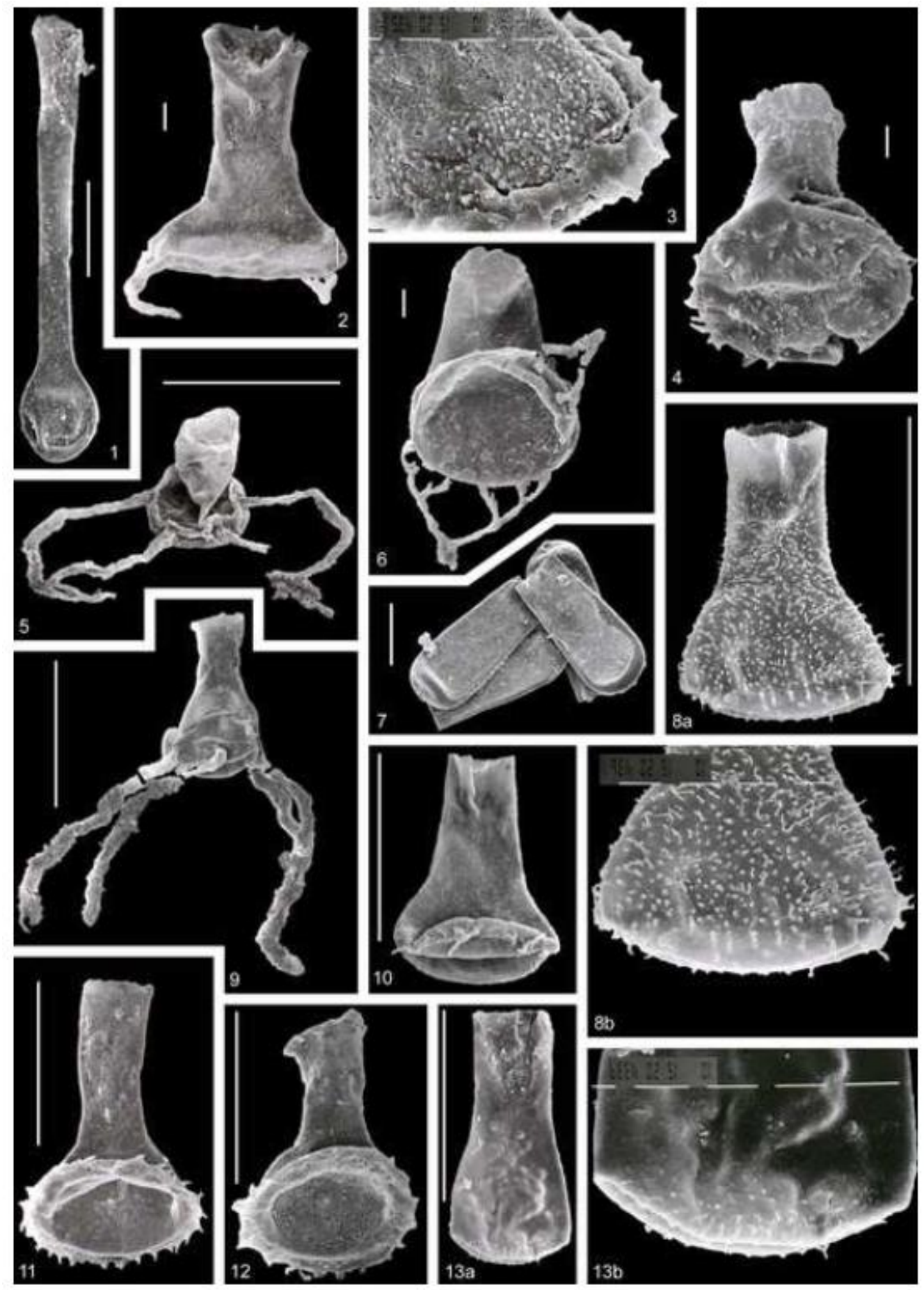

Plate V 

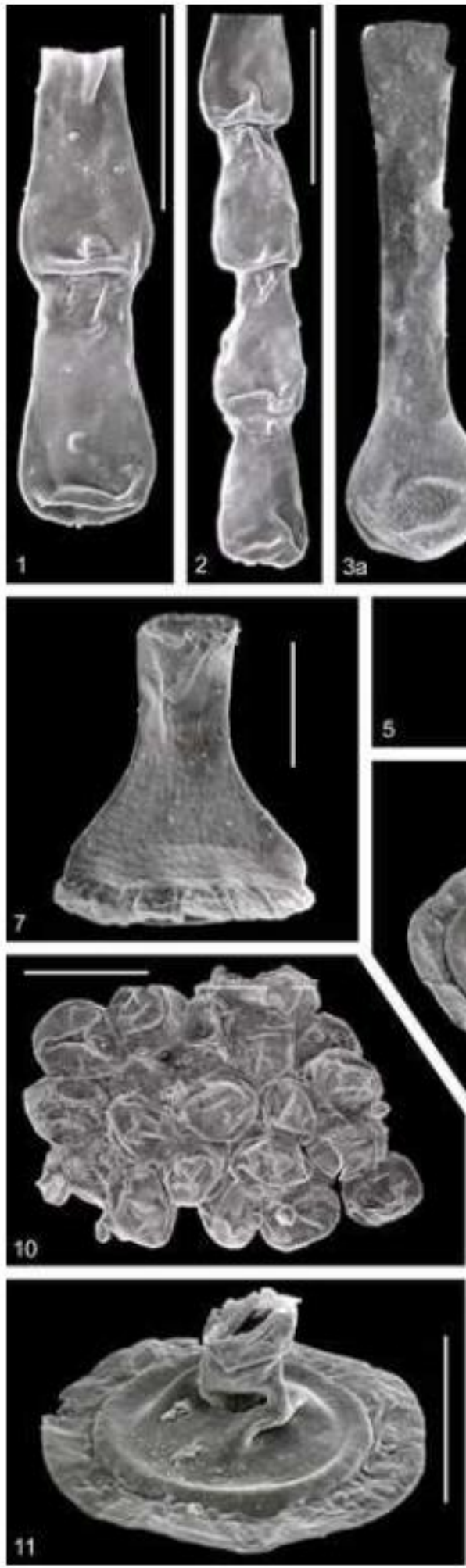

5
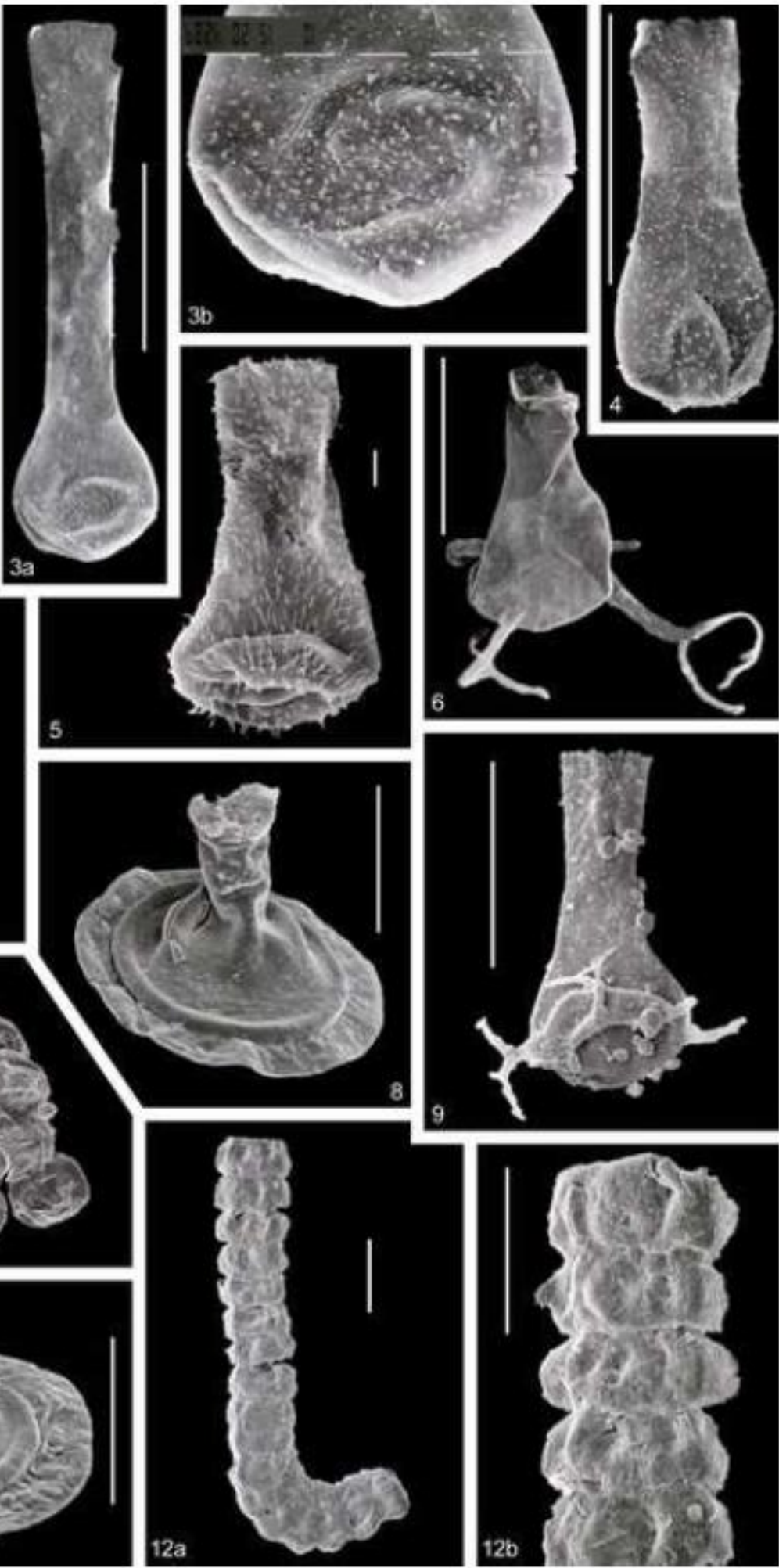

Plate VI 

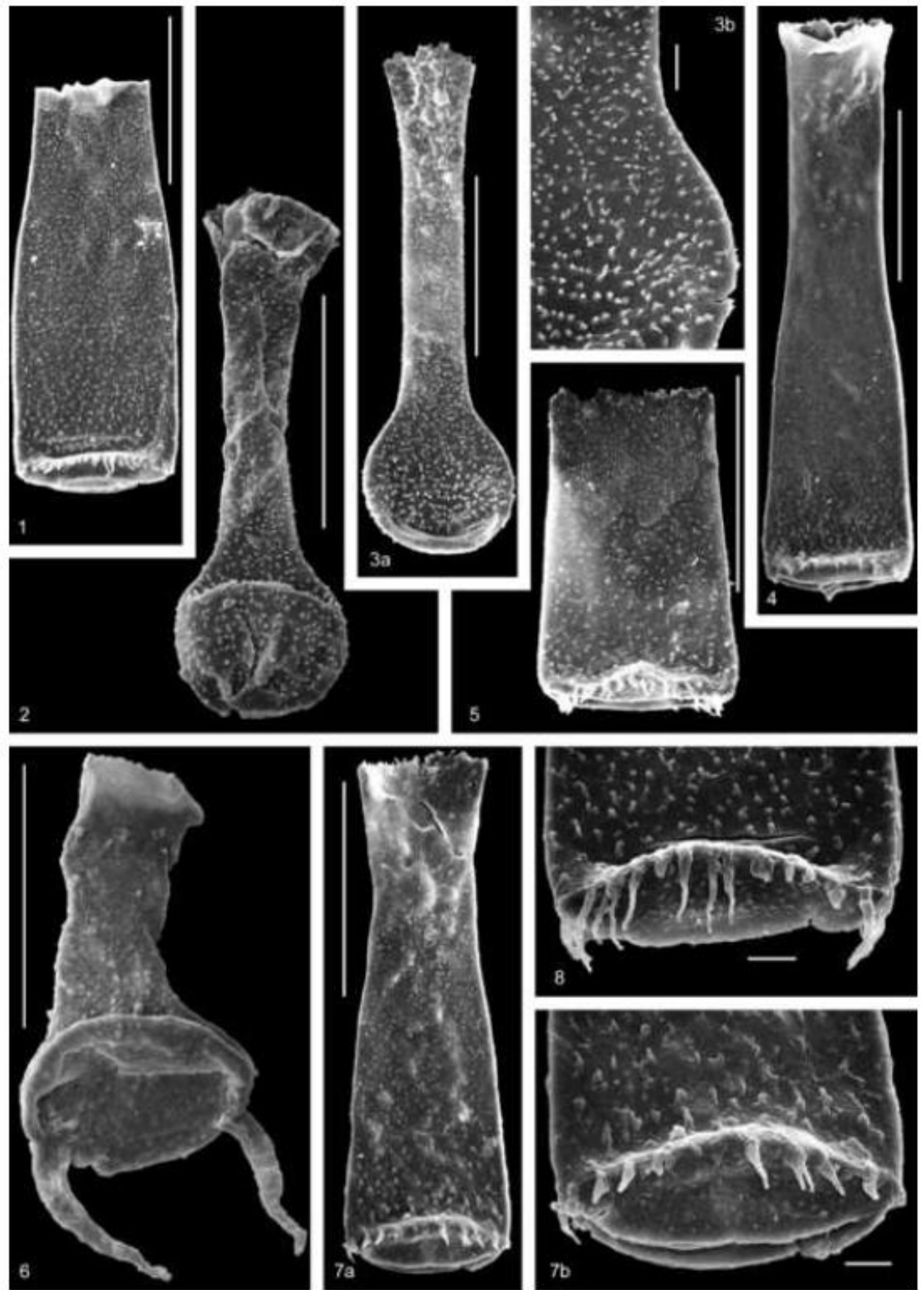

Plate VII 


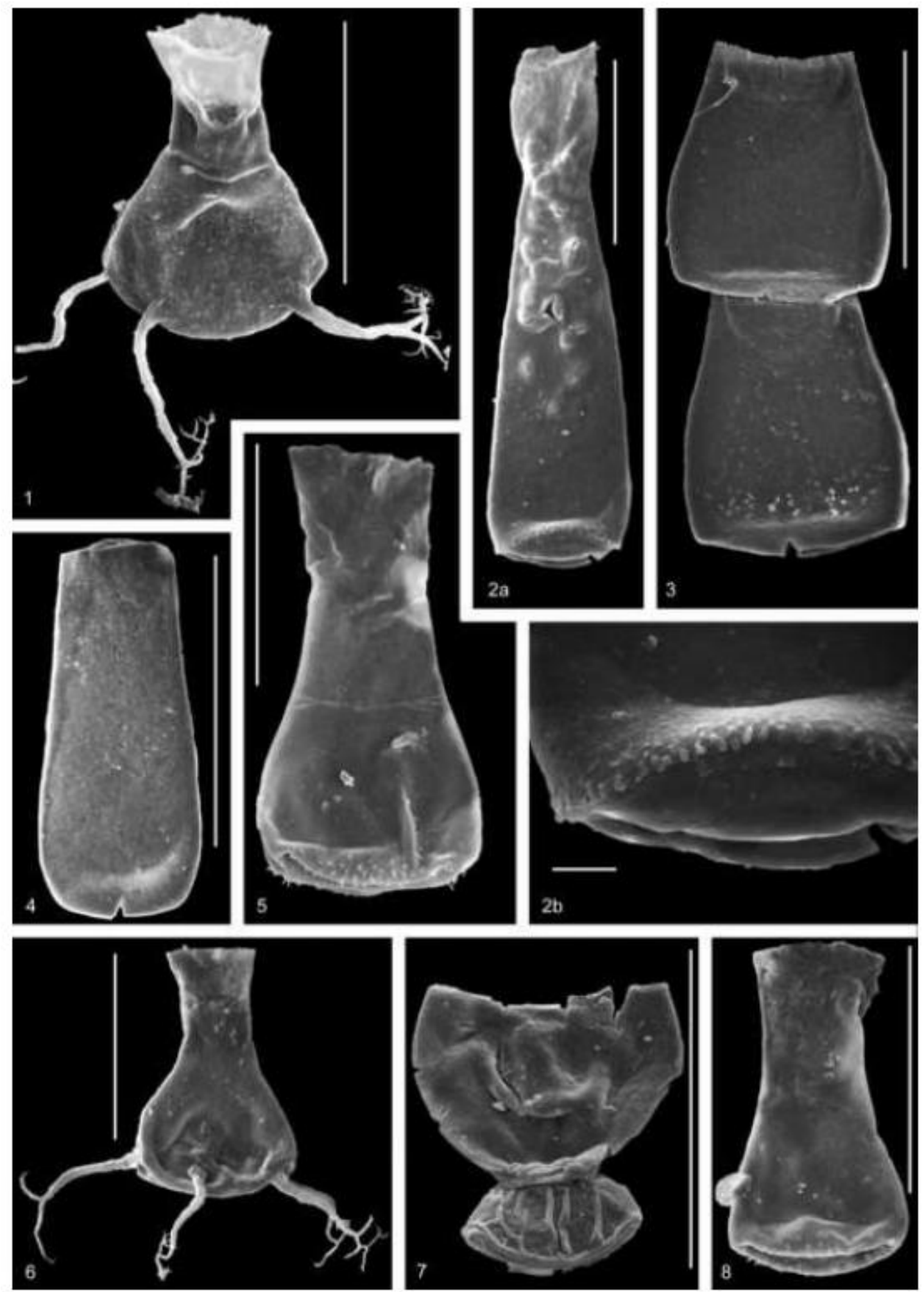

Plate VIII 

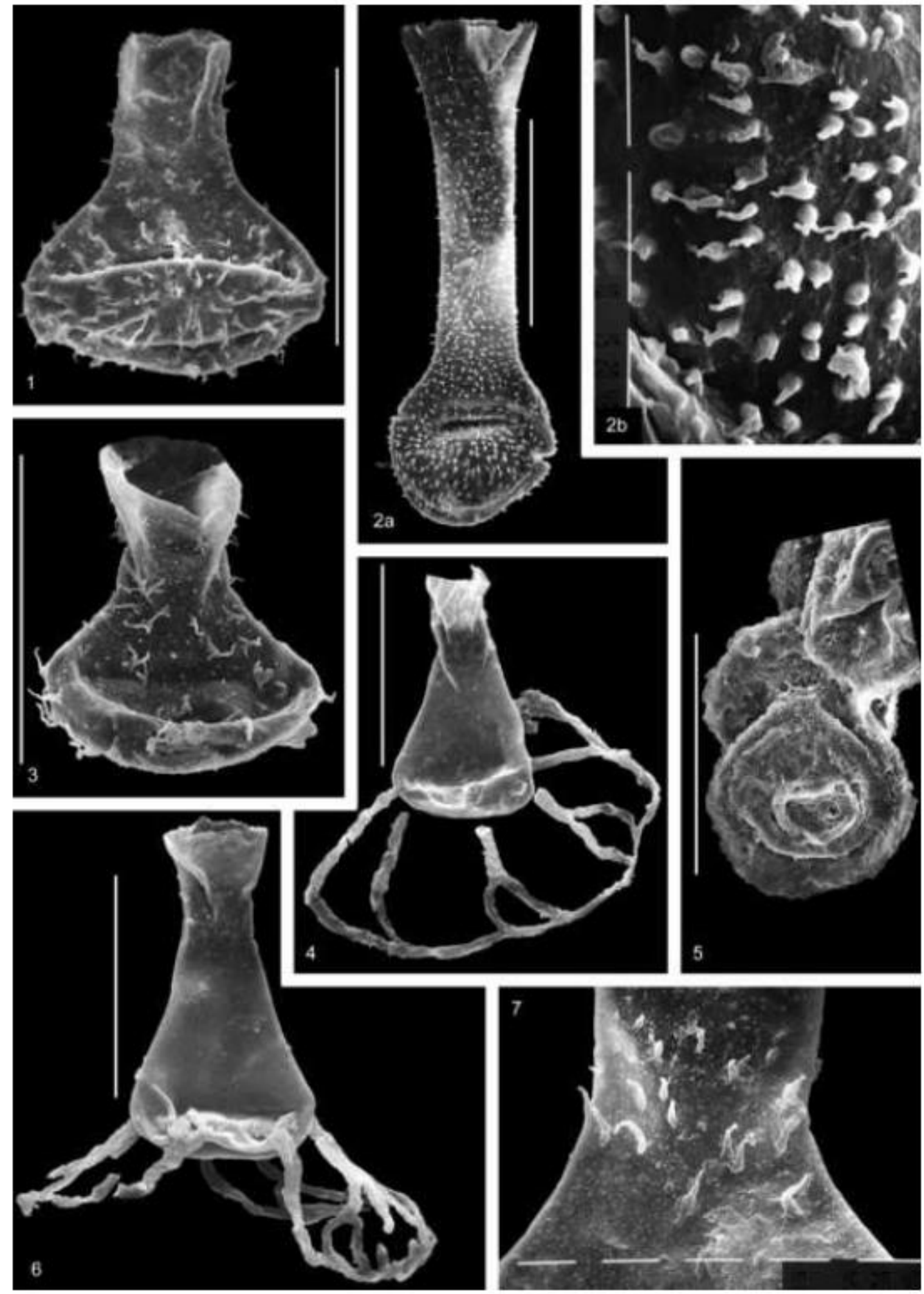

Plate IX 

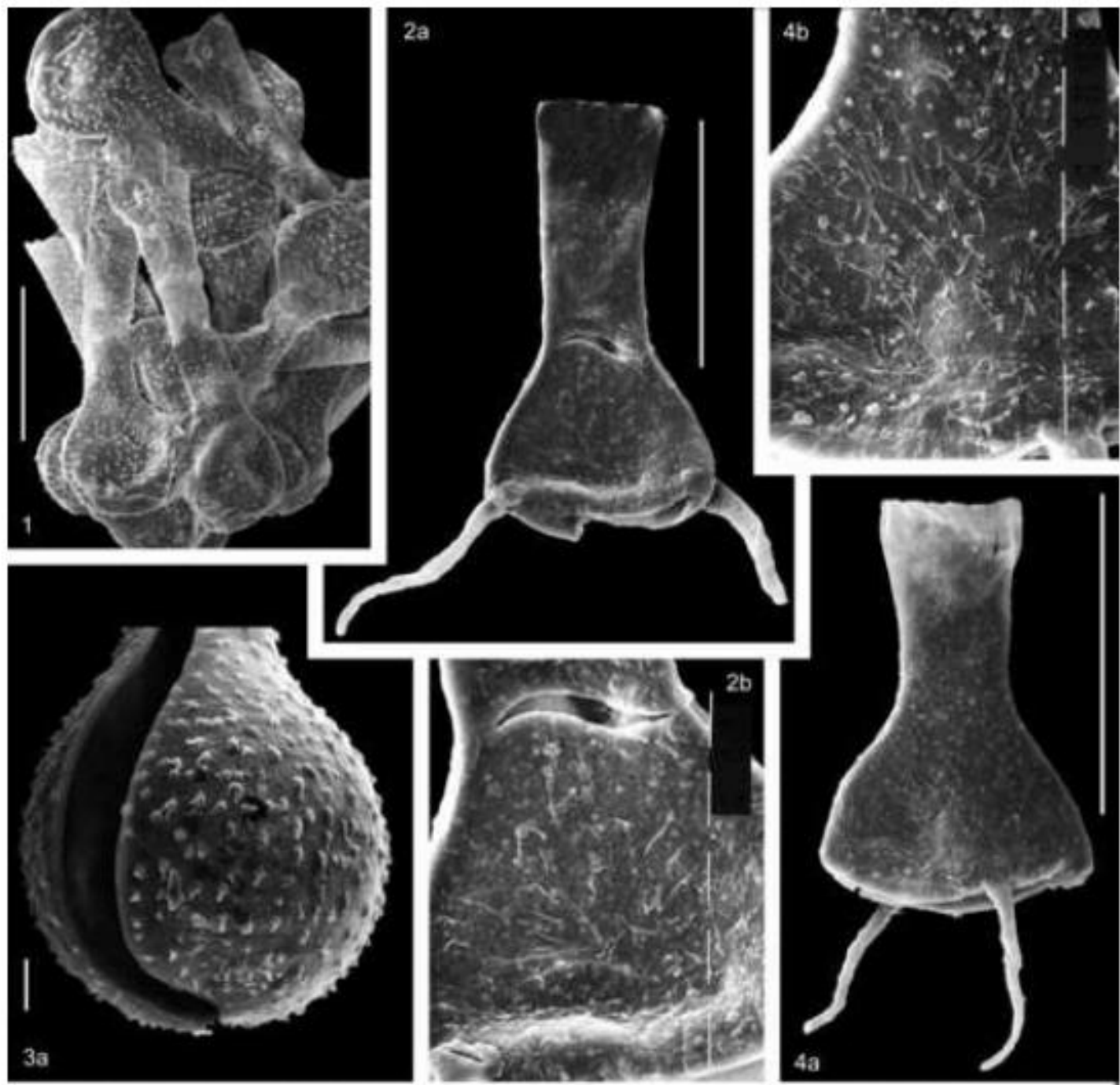

$3 \mathrm{a}$
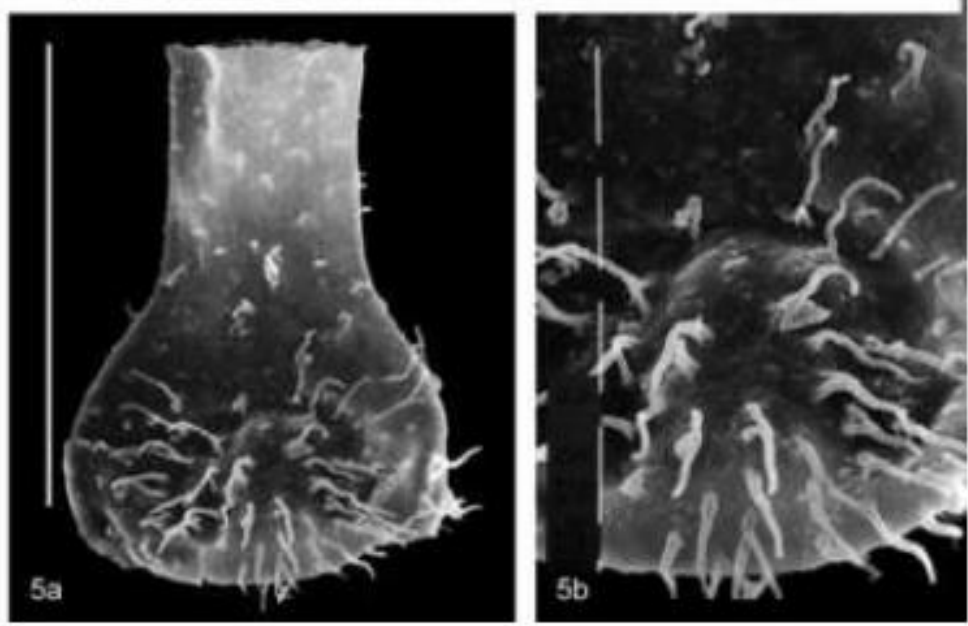

Plate X 

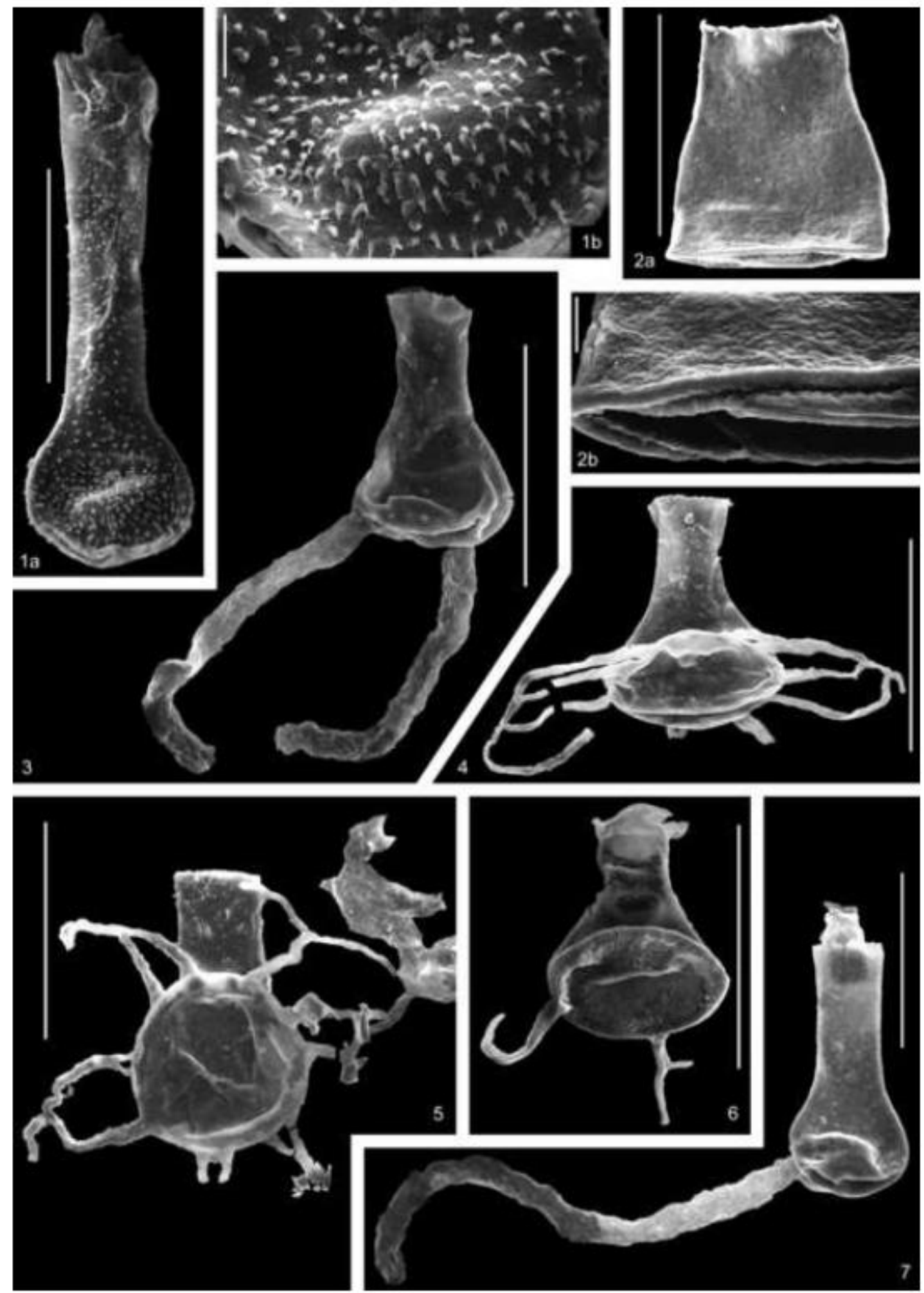

Plate XI 

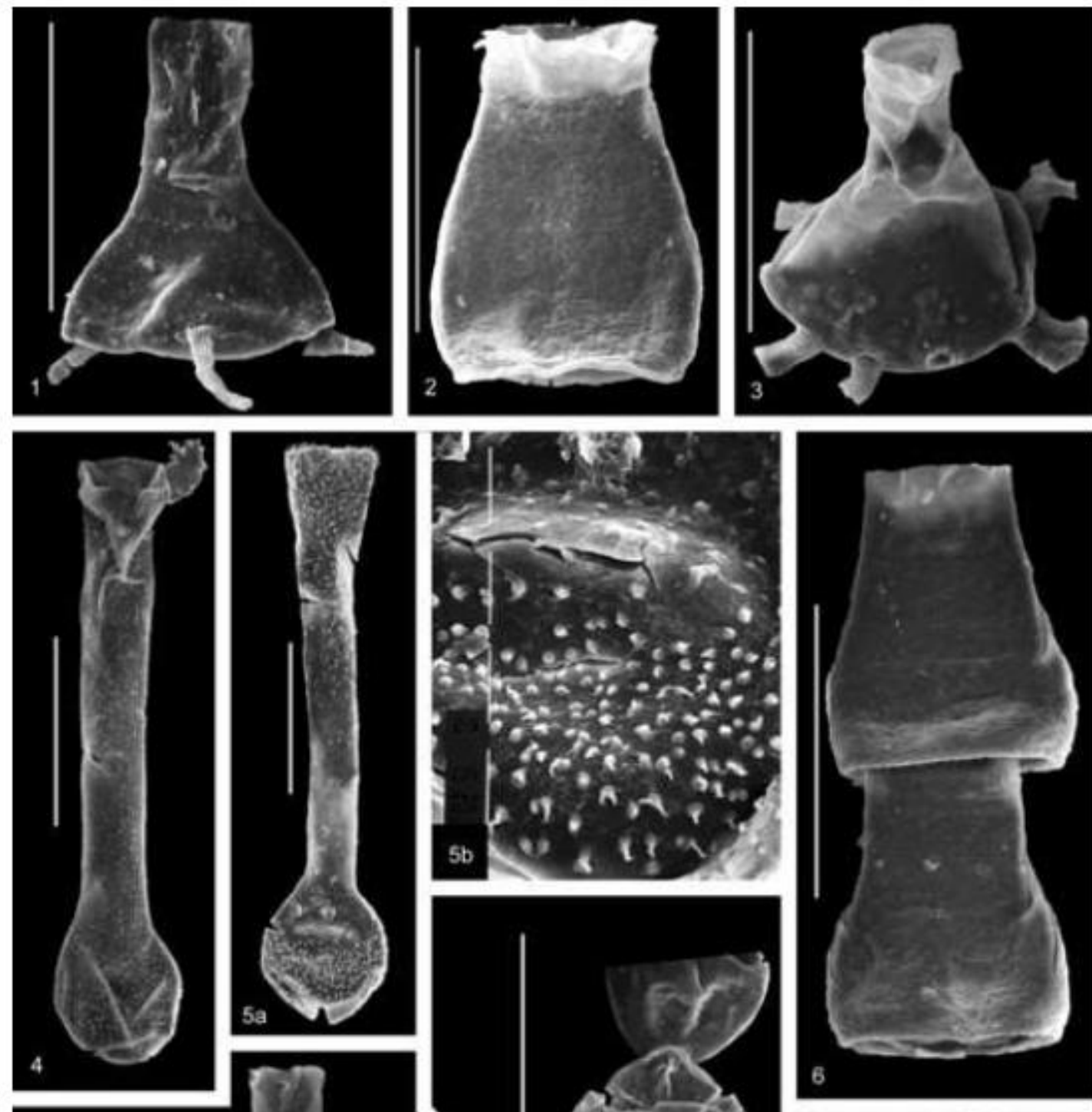

$5 b$

s 6
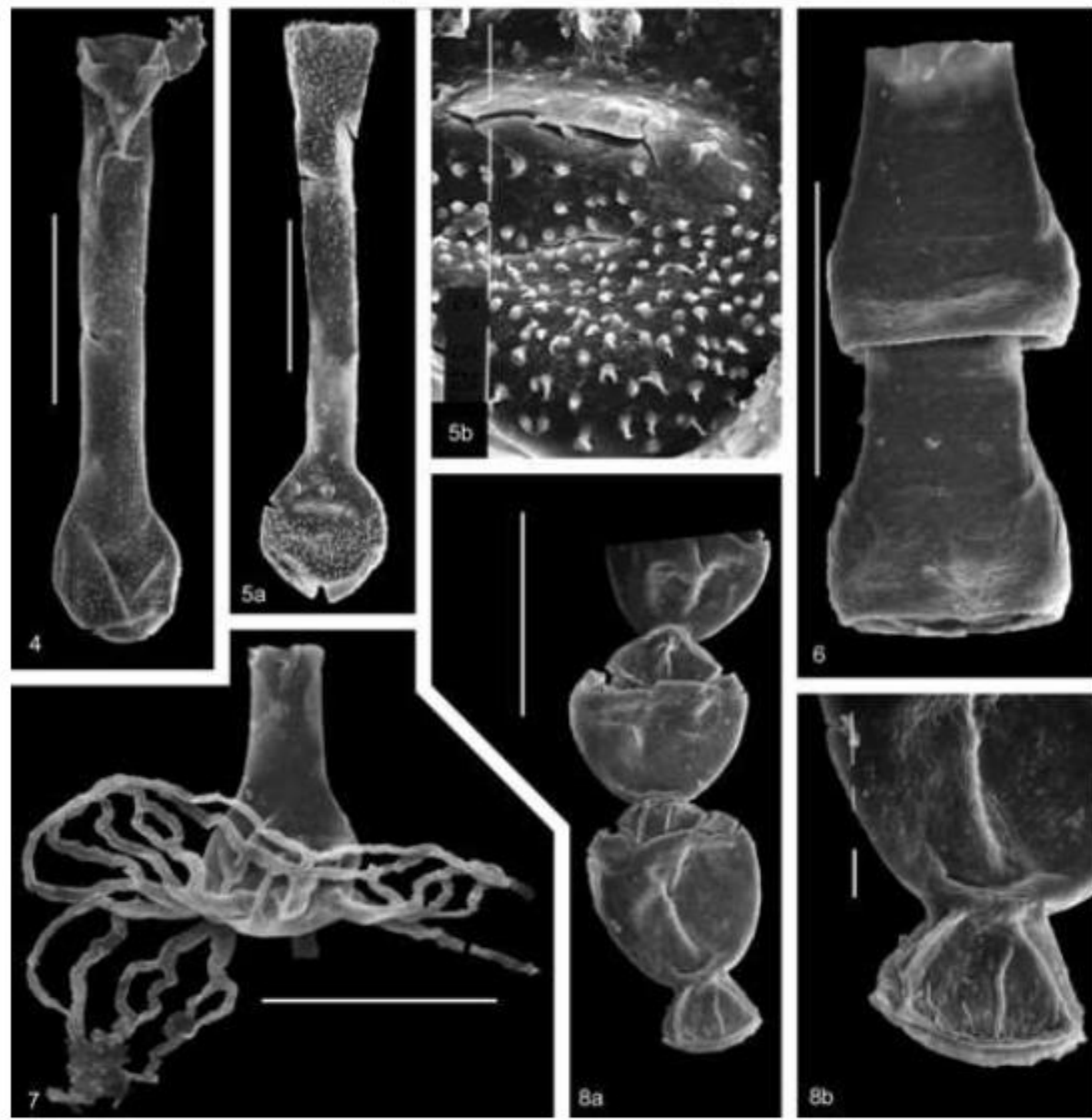

Plate XII 

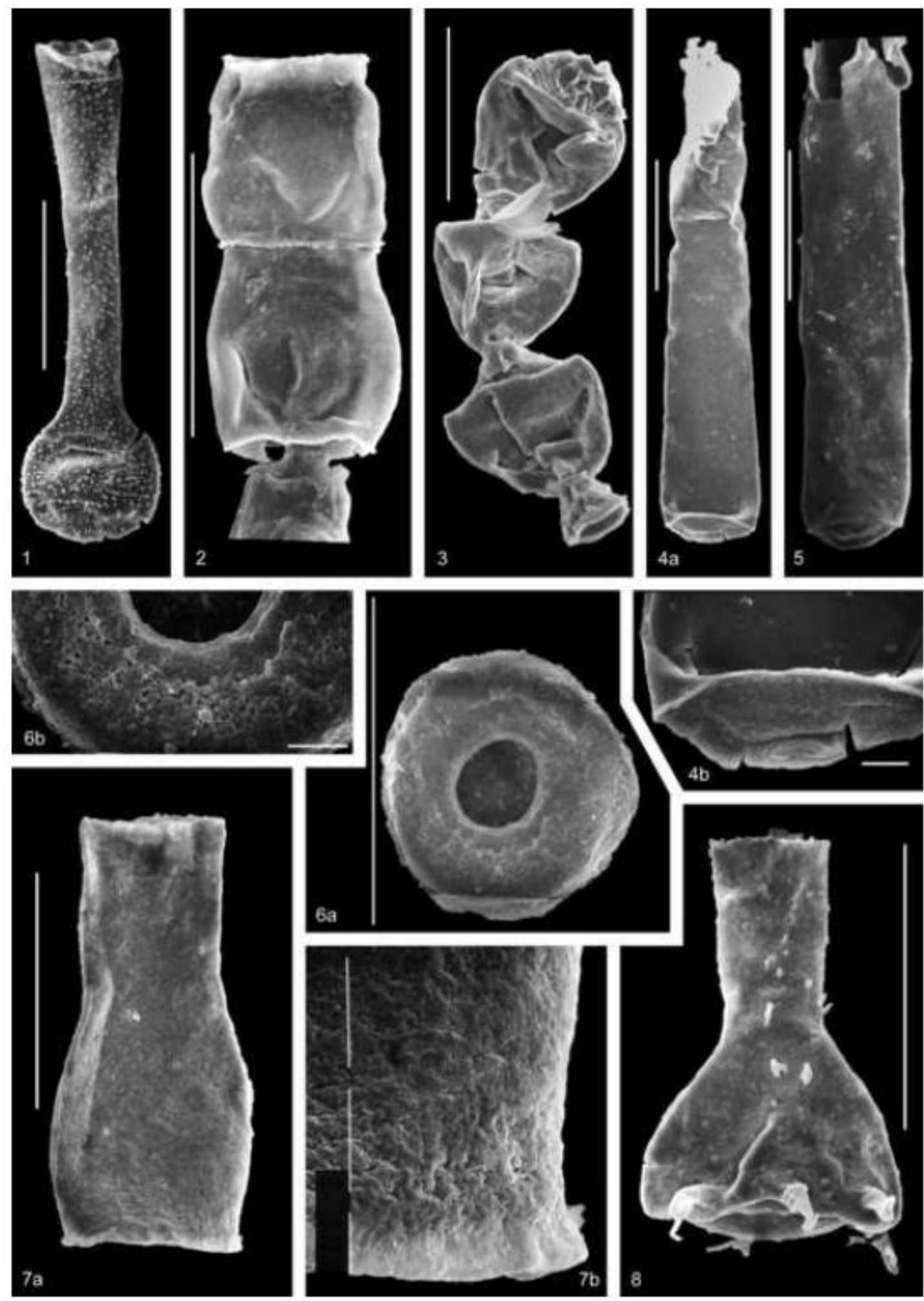

Plate XIII 

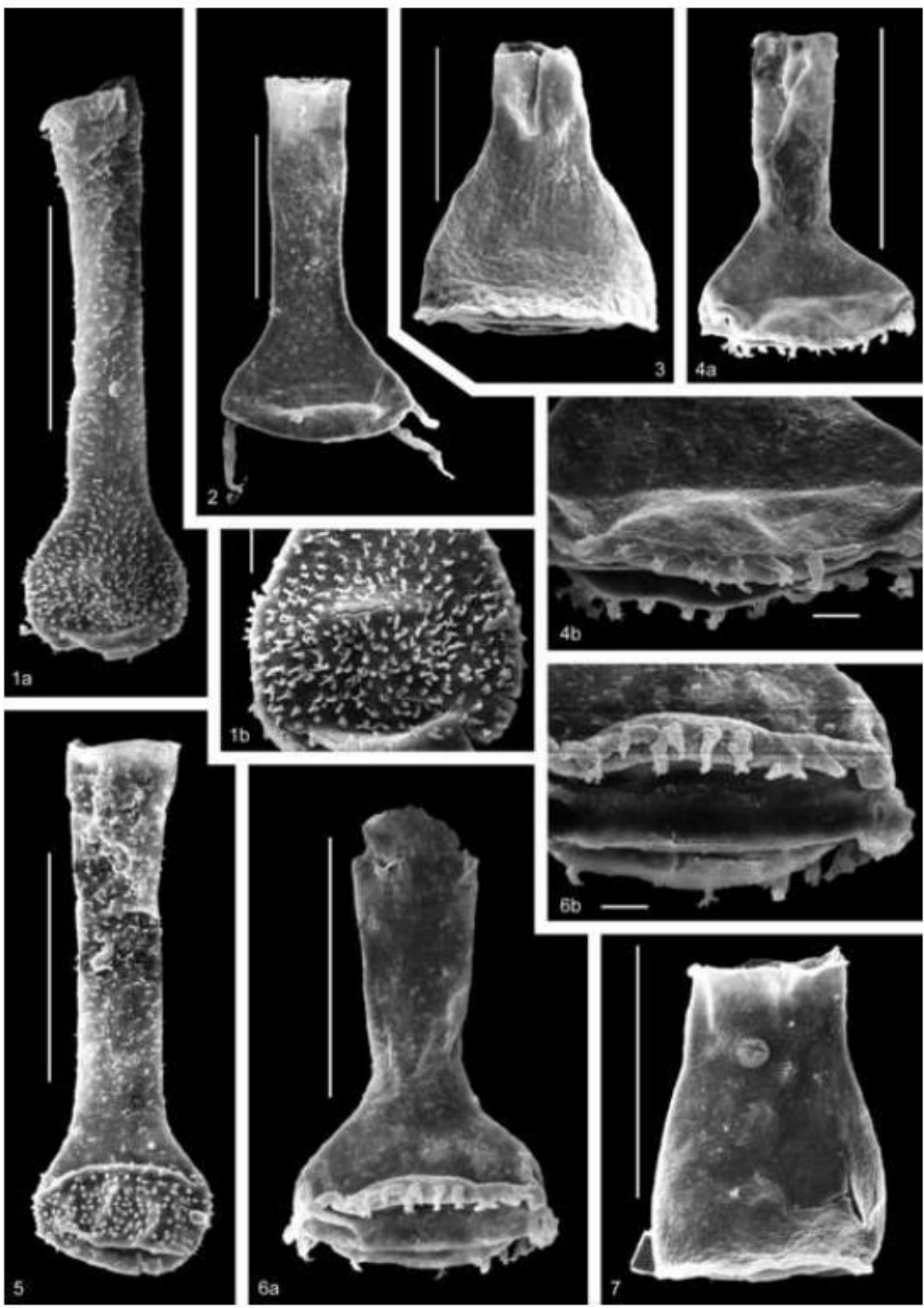

Plate XIV 

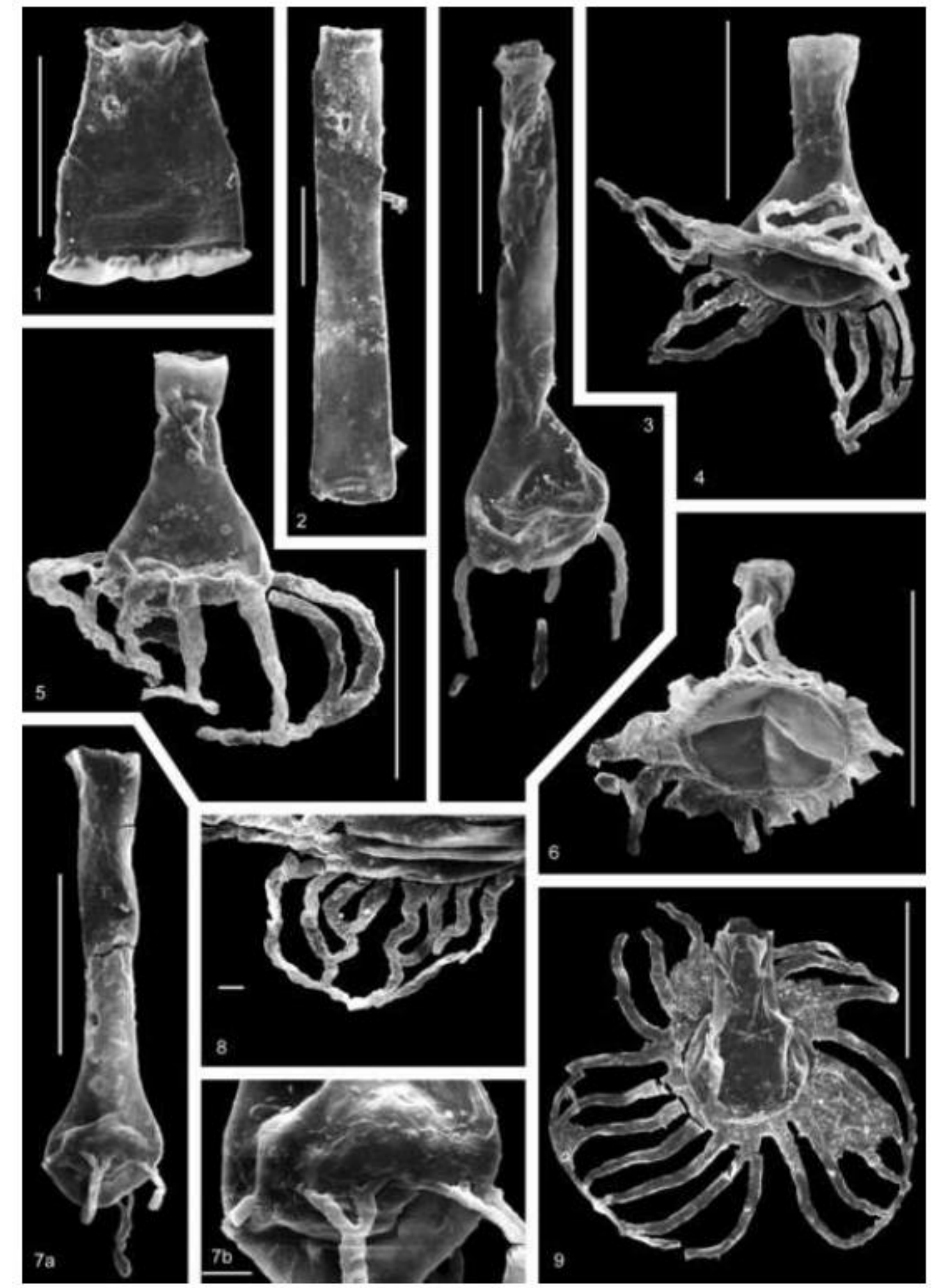

6

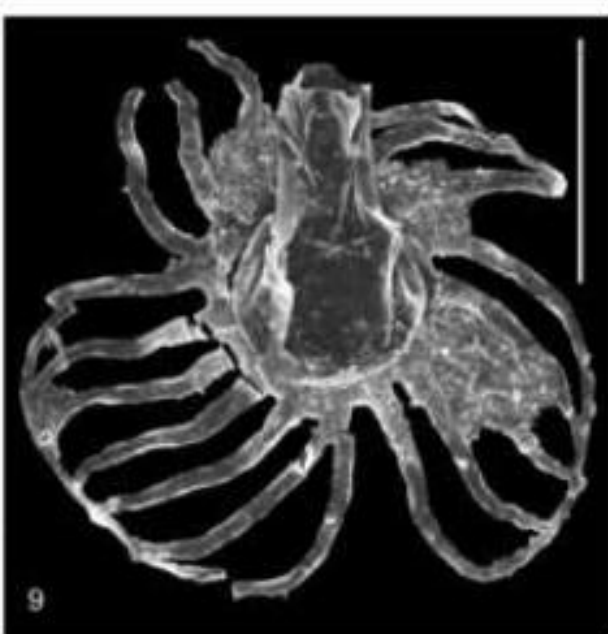

Plate XV 

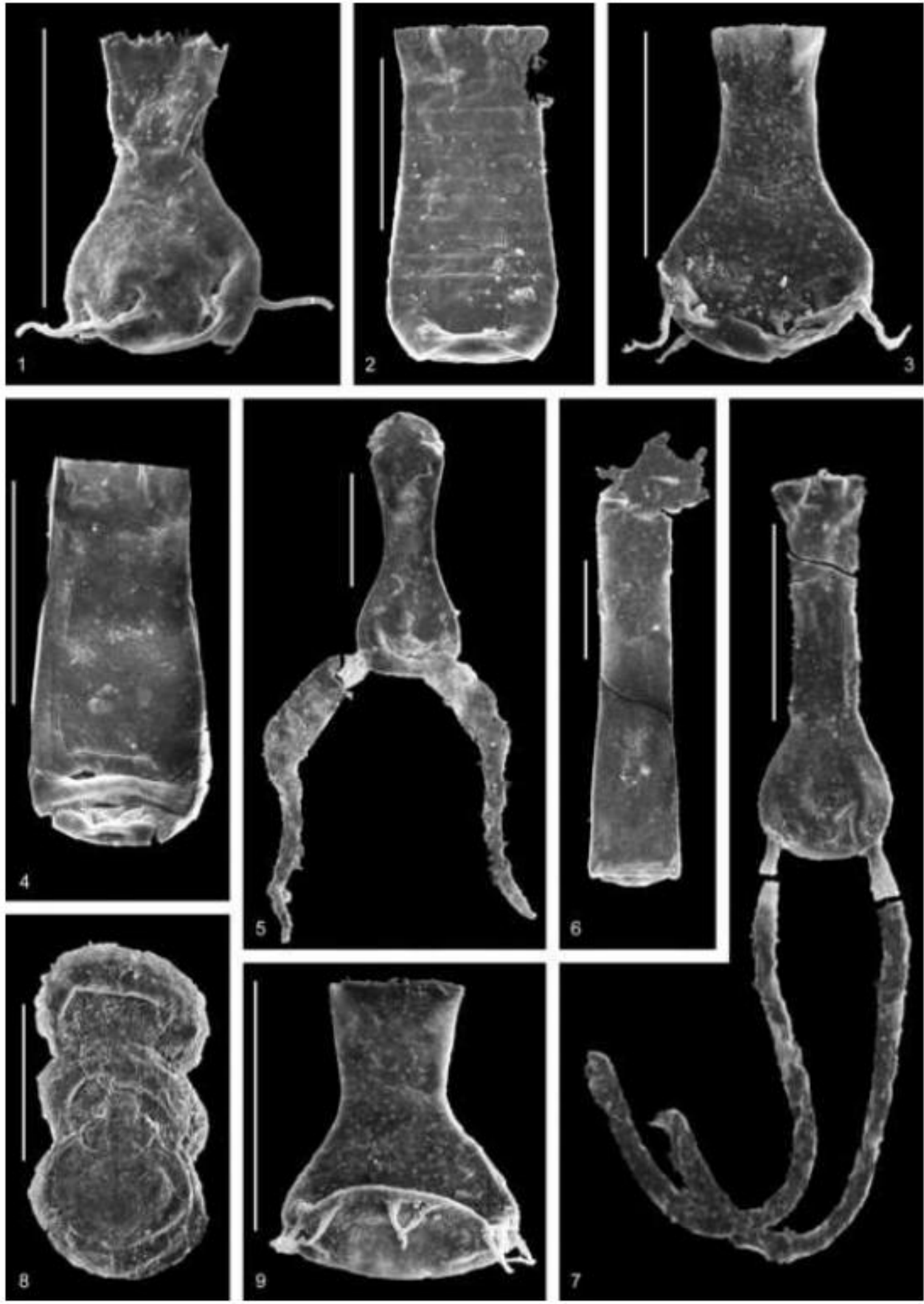

Plate XVI 

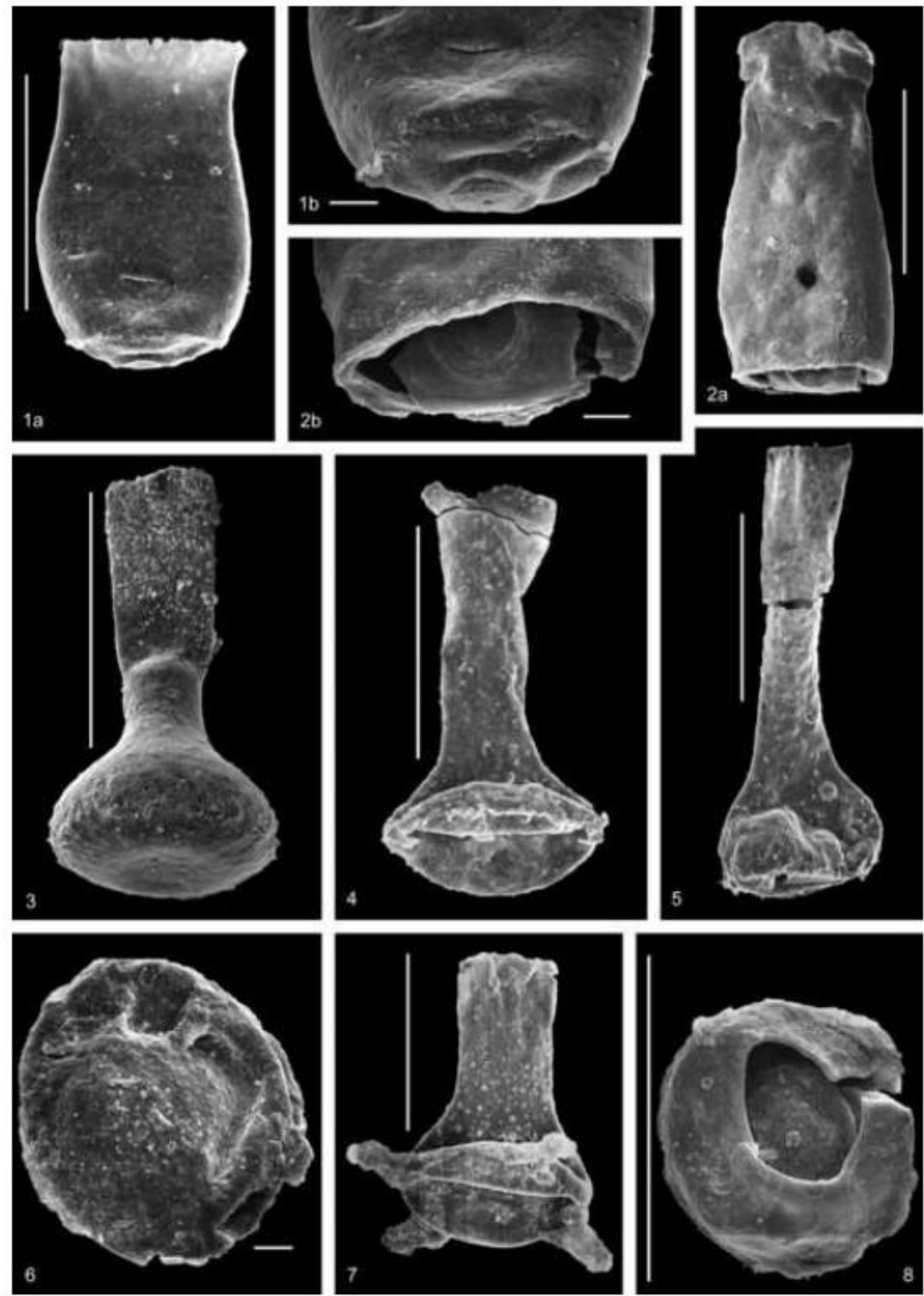

Plate XVII 

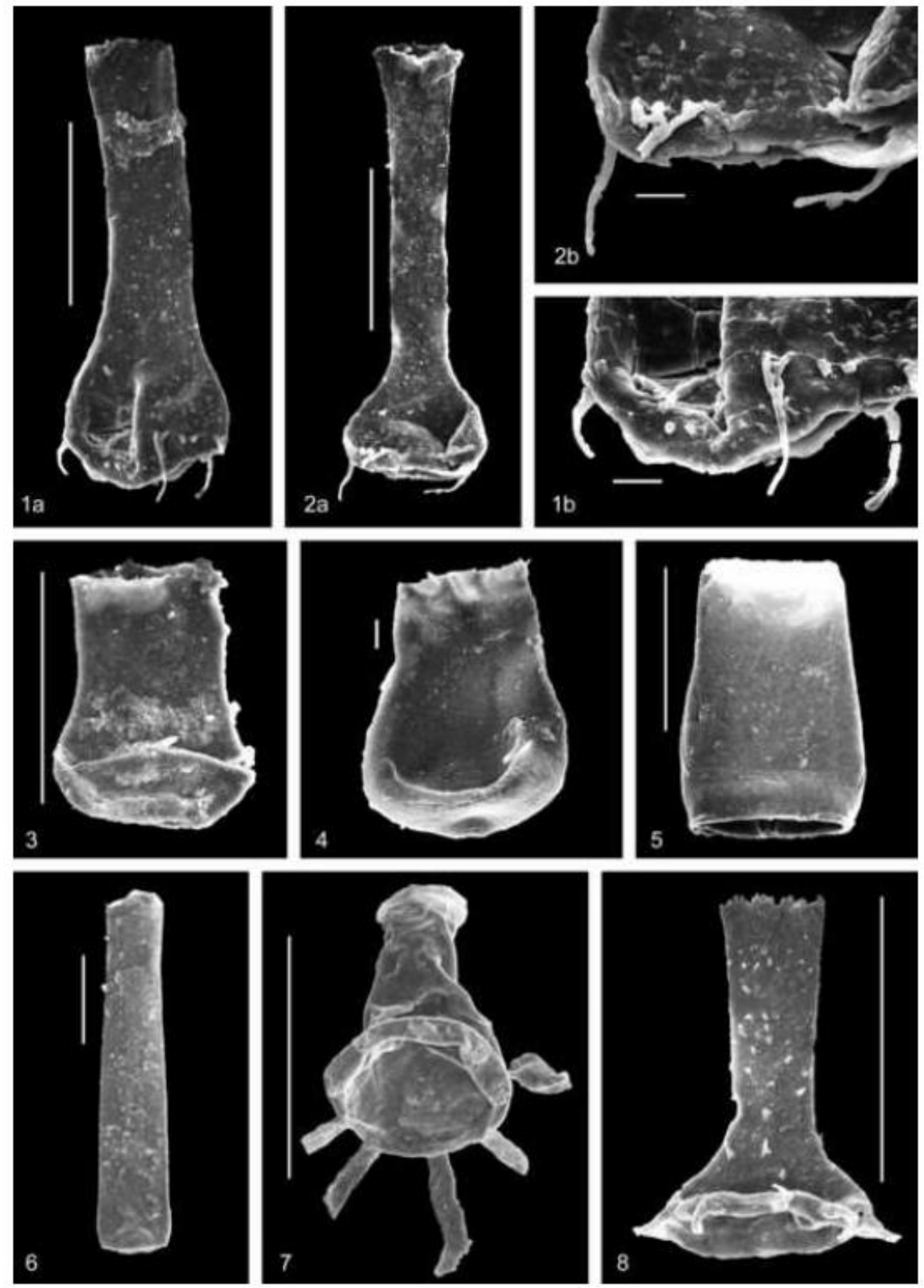

5
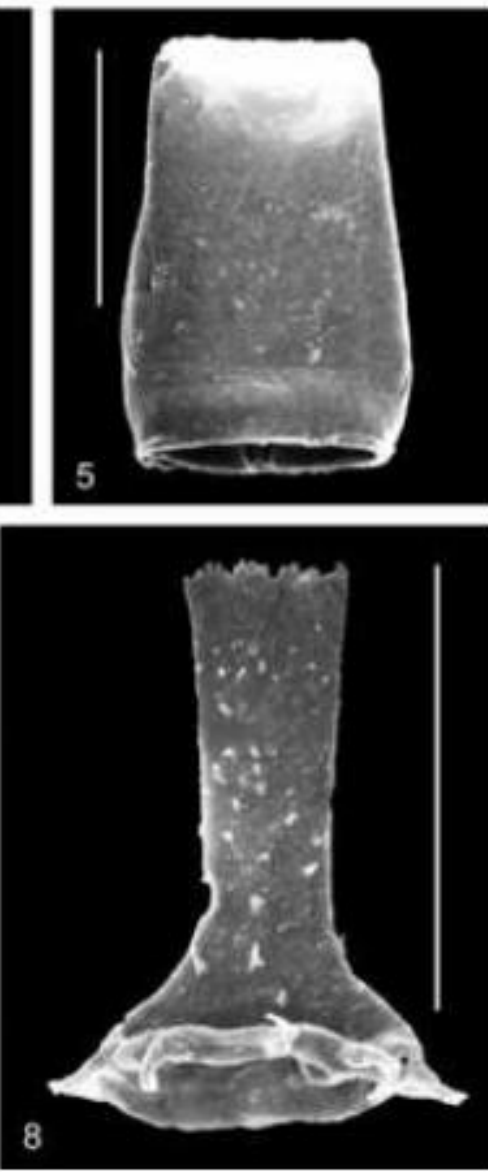

Plate XVIII 